\title{
Palynological zonation and
} palynofacies investigation of the Fjerritslev Formation (Lower Jurassic - basal Middle Jurassic) in the Danish Subbasin

BY

KAREN DYBKJ ER

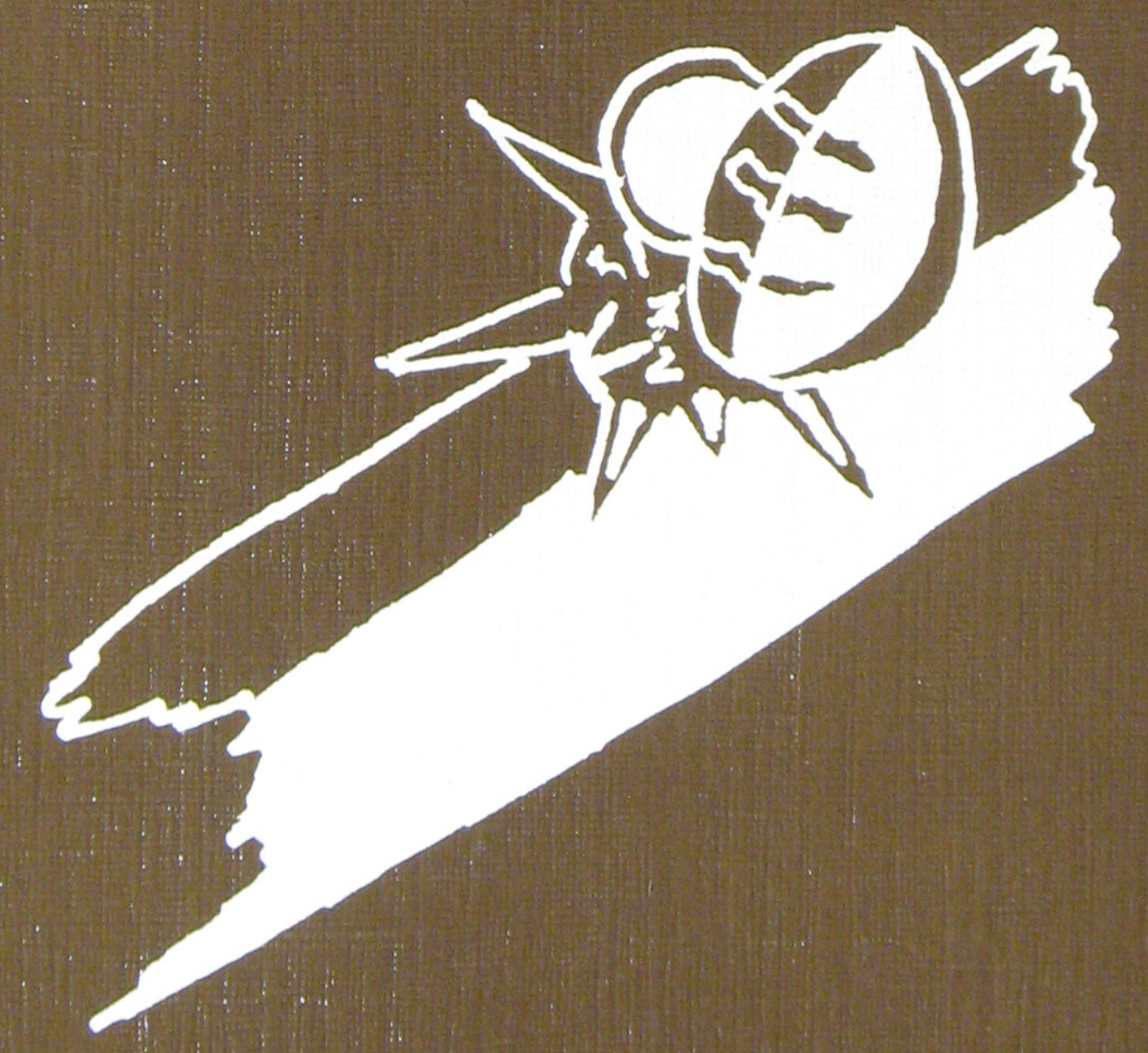


Palynological zonation and palynofacies investigation of the Fjerritslev Formation (Lower Jurassic - basal Middle Jurassic) in the Danish Subbasin

BY

KAREN DYBKJÆR 
Key words:

Biostratigraphy, palynology, palynofacies, Lower Jurassic, the Fjerritslev Formation, the Danish Subbasin, Denmark.

With 22 plates and 6 range-charts

\section{Vignette:}

Kerogen particles

DGU Serie A nr. 30

ISBN 87-88640-70-1

ISSN 0901-(0270

Oplag: 1000

Tryk: AiO Tryk as, Odense

Tegning: Lis Olesen, Helle Zetterwall og Kirsten Andersen

Dato: 31.12.1991

Manuscript accepted November 1989

Karen Dybkjær, Geological Survey of Denmark,

Thoravej 8, DK-2400 København NV, Denmark

Redaktion: Leif Banke Rasmussen

(C) Danmarks Geologiske Undersøgelse,

Thoravej 8, DK-2400 København NV

I kommission hos: Geografforlaget ApS.

Ekspedition: Fruerhøjvej 43, 5464 Brenderup

Telefon: 64441683 


\section{Contents}

\author{
Abstract \\ Introduction \\ The four borehole sections . \\ The Fjerritslev Formation . \\ Depositional environment \\ Organic matter \\ Materials and methods. \\ Sampling \\ Palynological preparation \\ Total organic carbon (T.O.C.) measurements . \\ Thermal alteration index (T.A.I.) . \\ Microscopical examination and counting \\ The biostratigraphical investigation .......... \\ Results of the biostratigraphical counting .... 16 \\ Records of reworked palynomorphs ........ 16 \\ Records of caved palynomorphs ......... 16 \\ Systematics . . . . . . . . . . . . . . . . . 18 \\ Spores and pollen ............... 18 \\ Aquatic palynomorphs................. 29 \\ Other microfossils ................ 32 \\ Palynostratigraphy ............... 33

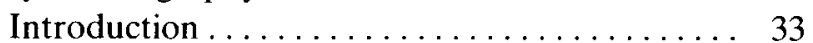 \\ Definition of spore-pollen zones ........ 33 \\ Definition of dinoflagellate cyst zones ...... 41
}

Stratigraphic conclusions . . . . . . . . . 42

Comparison with previous work......... 50

Chronostratigraphic boundaries compared with

lithostratigraphic units .............. 52

Palynofacies analysis................ 54

Introduction . . . . . . . . . . . . . . . . 54

Kerogen classification. . . . . . . . . . . . . . . 54

Palaeoenvironmental parameters ......... 55

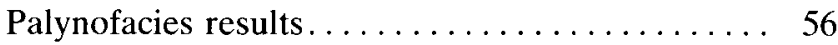

Introduction $\ldots \ldots \ldots \ldots \ldots \ldots \ldots \ldots \ldots \ldots$

General environmental interpretation of the

Gassum and Fjerritslev Formations......... 56

Stratigraphic variation ............. 56

Variations in kerogen-assemblages from

Gassum-1 . . . . . . . . . . ....... 66

Correlation with eustatic sea-level changes ... 70

Geographical variation............... 71

Amount, type and maturation of organic

matter ..................... 74

Acknowledgements.................. 75

References ..................... 76

Plates $1-22 \ldots \ldots \ldots \ldots \ldots \ldots \ldots \ldots \ldots \ldots$

Appendices A-F . . . . . . . . . . . . . . . . . . 129

Range-charts, tables $1-6 \ldots \ldots \ldots \ldots 151$ 


\section{Abstract}

A detailed study of the palynology and palynofacies of the Fjerritslev Formation (Lower Jurassic - basal Middle Jurassic) has resulted in the definition of four spore/ pollen zones and four dinoflagellate cyst zones. The spore/pollen zones are the Corollina - Ricciisporites Zone (Late Rhaetian), the Cerebropollenites macroverrucosus Zone (Sinemurian - Pliensbachian), the Spheripollenites - Leptolepidites Zone (Toarcian), and the Perinopollenites elatoides Zone (Middle Jurassic). The dinoflagellate cyst zones are the Rhaetogonyaulax rhaetica Zone (Rhaetian), the Dapcodinium priscum Zone (latest Rhaetian - earliest Sinemurian), the Liasidium variabile Zone (Sinemurian), and the Nannoceratopsis gracilis Zone (Late Pliensbachian - ?Bajocian/ Bathonian). These zones, and the Pinuspollenites Trachysporites Zone Lund 1977 (Hettangian), are proposed for use in the Danish Subbasin. The combined spore/pollen and dinoflagellate cyst zonation has resulted in a detailed biostratigraphical subdivision of the sequences studied.

A new combination, Manumia delcourtii (Pocock 1970) nov. comb. et emend., is proposed here, and the species description emended.

New photographs of the holotypes of some of the species erected by Nilsson (1958) are included in the plates.

The kerogen assemblages recorded from the Fjerritslev Formation, indicate a marine depositional environment, with a high but variable influence of terrestrially-derived organic particles. Stratigraphic variation in the kerogen assemblages generally correlate with the lithostratigraphical subdivision, and support previous environmental interpretations of the Fjerritslev Formation. Indications of strongly reducing conditions in the bottom waters were found in the Stenlille-2 borehole, in samples here referred to the Early Toarcian. The variations in the kerogen assemblages in the sequence investigated from the Gassum-1 borehole are not correlatable with the other boreholes, but seem primarily to reflect a distinct decrease in bioturbation in the Late Sinemurian.

The Fjerritslev Formation does not generally represent a potential source rock for oil. Some levels (parts of the F-III member) show, however, the characteristics of a fair to good source rock. The organic matter is generally immature or only at the earliest stage of maturity. 


\section{Introduction}

Few palynological investigations have been made of the Lower Jurassic deposits in the Danish Subbasin (Evitt 1961a, 1961b, Bertelsen 1978, 1979, Dybkjær 1988); none of these have included palynofacies observations. This study concentrates on the Lower Jurassic to basal Middle Jurassic Fjerritslev Formation in the Danish Subbasin (eastern Norwegian - Danish Basin; see figs 1 and 2). The study was based on the Fjerritslev-2, Frederikshavn-2, Stenlille-2, and Gassum-1 boreholes.

The objectives of the study were:

1) To produce a palynological zonation and dating of each of the investigated sequences, utilising a combination of miospores (microspores and pollen) and dinoflagellate cysts.

2) To erect a palynological zonation for the Fjerritslev Formation, for use within the Danish Subbasin, based on the results from the individual wells, together with results from earlier investigations.

3) To carry out a detailed palynofacies investigation of the Fjerritslev Formation, and to compare the results with previous lithological and palaeo-ecological investigations.

\section{The four borehole sections}

The locations of the four boreholes are shown in figs 1 and 2, and the lithology and stratigraphy of the total well sections are shown in fig. 3 .

\section{Fjerritslev-2}

The Fjerritslev-2 borehole was drilled in the spring of 1958 by DAPCo (the Danish American Prospecting Company). It is located adjacent to the Fjerritslev Fault, and is on the flank of a salt pillow. This borehole contains the type section of the Fjerritslev Formation (Larsen 1966, Michelsen 1978). The objectives of the borehole were both to establish the stratigraphy and to test the hydrocarbon potential of the Rhaetian-Jurassic strata. The borehole reached a depth of $2345 \mathrm{~m}$ below rotary table (b.r.t.) and terminated in Keuper shales (Sorgenfrei \& Buch 1964). No traces of hydrocarbons were encountered (Well Data Summary Sheet, 1981).

\section{Frederikshavn-2}

The Frederikshavn-2 borehole was drilled in the spring of 1952 by DAPCo. The drilling was part of a programme, including the wells Frederikshavn-1, -2 and -3 , to test the structural situation and the origin of the natural gas in the area. The borehole reached a depth of 1079 m b.r.t. in (presumed) Triassic arkose (Sorgenfrei \& Buch 1964). No traces of hydrocarbons were encountered (Well Data Summary Sheet, 1981).

\section{Stenlille-2}

The Stenlille-2 borehole was drilled by Dansk Olie \& Gasproduktion A/S (DOPAS) during the summer of 1987. The borehole is located centrally on a saltdome structure and is part of a series of closely-spaced boreholes designed to test the possibility of using the domal structure as an underground store for natural gas. It is planned that the sandy Gassum Formation (Rhaetian) should function as the store, and the overlaying Fjerritslev Formation as the seal. The borehole reached a depth of $1662 \mathrm{~m}$ b.r.t., terminating in Upper Triassic sandstone (the Vinding Formation) (Frandsen 1988).

\section{Gassum-1}

The Gassum-1 borehole was drilled by DAPCo between March 1948 and March 1951 (the operation was suspended from February 1949 to November 1950). The borehole is located on the flank of a salt pillow, and contains the type section of the Gassum Formation (Larsen 1966, Bertelsen 1978). The objective was to test the Rhaetian-Jurassic-Lower Cretaceous interval. The boring reached a depth of $3462 \mathrm{~m}$ b.r.t., terminating in (presumed) Permian sediments (Sorgenfrei \& Buch 1964).

\section{The Fjerritslev Formation}

\section{Lithology and lithostratigraphy}

The first lithological and lithostratigraphical observations from the Gassum-1 borehole were presented by Norwood, Nørvang and von Elm (1951) and by Gre- 


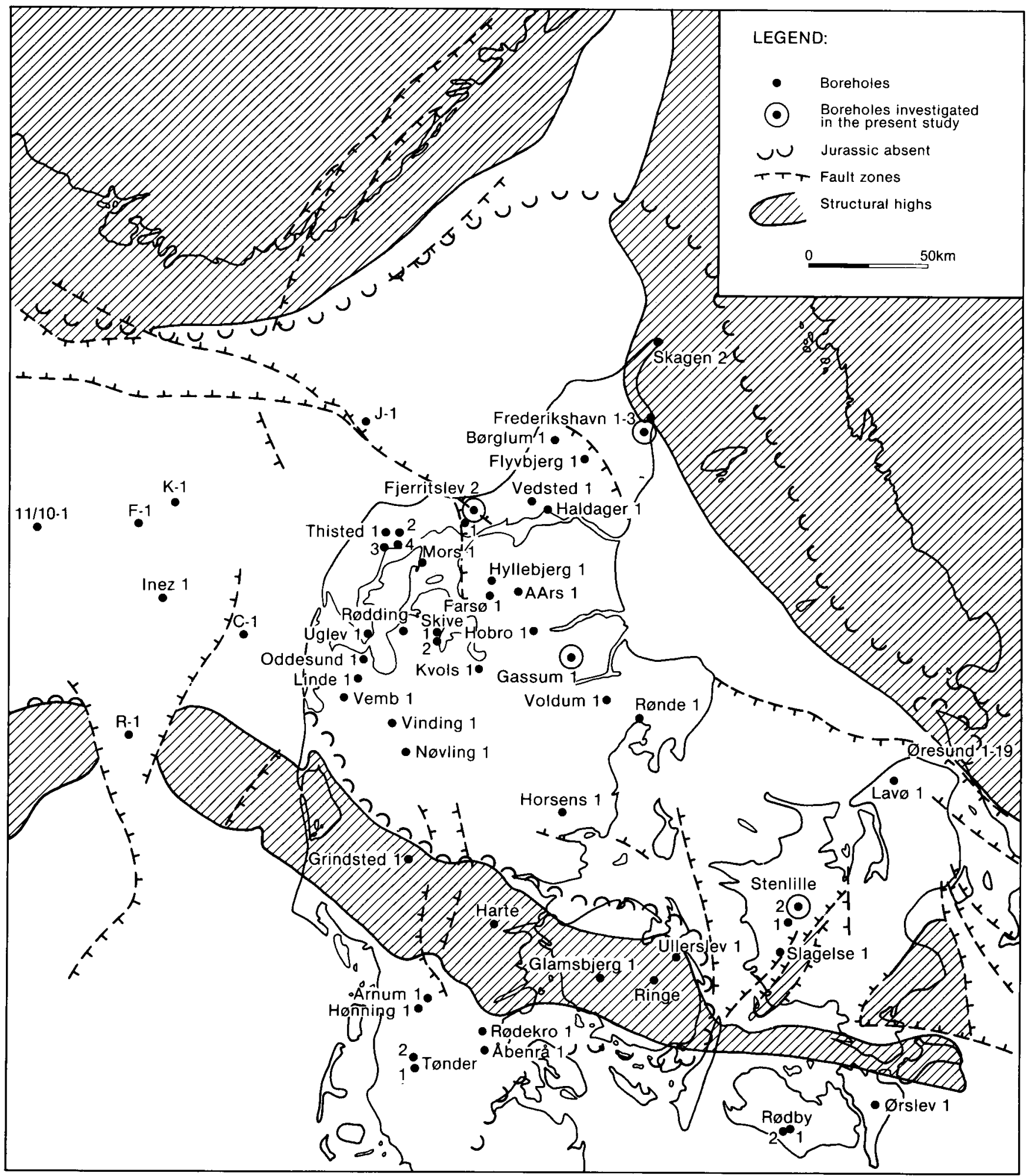

Fig. 1. The main Jurassic structural elements in the Danish area, simplified from Michelsen (1978). The boreholes shown form the regional subsurface database (see Fig. 2); this study focusses on the encircled wells.

gersen and Sorgenfrei (1951). Sorgenfrei and Buch (1964) described the lithological sequences from several Danish boreholes, including the Lower Jurassic in the Fjerritslev-2, Frederikshavn-2, and Gassum-1 boreholes.

A lithostratigraphical subdivision of the Jurassic deposits in the Danish Subbasin was presented by Larsen (1966). Michelsen (1976, 1978, 1989) revised this scheme, mainly on the basis of petrophysical logs; he amended several of the formations, and subdivided further into members.

Pedersen $(1983,1985$, 1986) studied the lithology, trace- and body fossils, and sedimentary structures within the Fjerritslev Formation. The studies were based on cores from several Danish boreholes, including Gassum-1, and resulted in detailed interpretations of the depositional environment.

Frandsen (1988) described the Stenlille-2 borehole; 


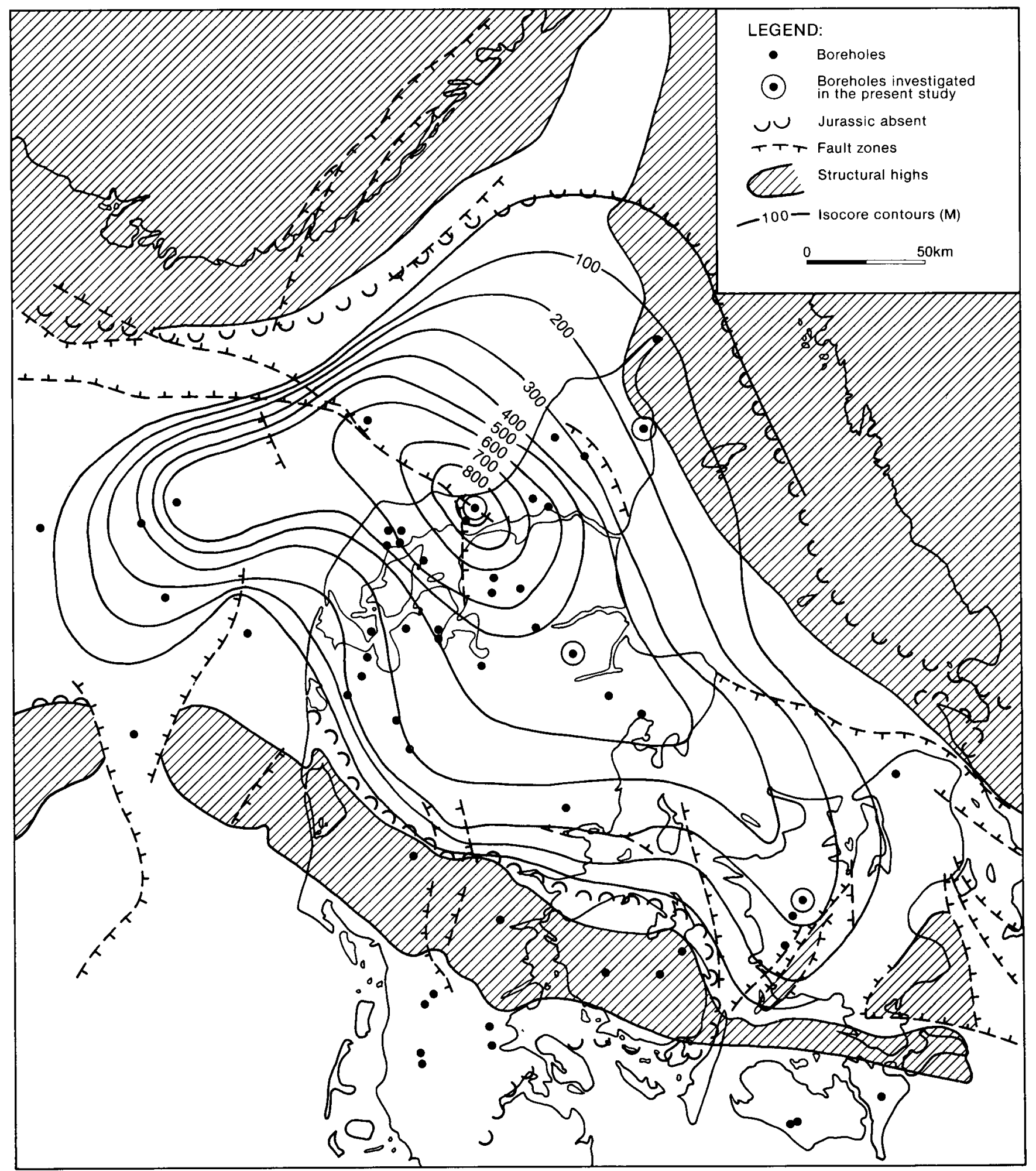

Fig. 2. Isocore contours of the Lower Jurassic Fjerritslev Formation. After Michelsen (1978), modified on the basis of new borehole data.

the lithological description and lithostratigraphical subdivision of the sequence used here (figs 3 and 9) are based on that account.

The lithological descriptions and lithostratigraphical subdivisions of the Fjerritslev-2, Frederikshavn-2, and Gassum-1 boreholes used here (figs 3, 7, 8 and 10) are based on the work of Sorgenfrei and Buch (1964), Michelsen (1978) and Pedersen (1986). The validity of the subdivision of the Lower Jurassic sequence in the
Gassum-1 borehole presented by Pedersen (1986) is questionable. The subdivision was indicated on a figure (fig. 6), and was not discussed further. It has, however, been used here to permit detailed comparison with the other sequences investigated.

The Fjerritslev Formation was defined in the Fjerritslev-2 borehole by Larsen (1966). Michelsen (1978) amended the formation, subdivided it into four informal lithostratigraphical units (members F-I to F- 


$\begin{array}{cccc}\text { FRH-2 } & \text { FJ-2 } & \text { GA-1 } & \text { ST-2 } \\ \text { (A) } & \text { (B) } & \text { (C) } & \text { (D) }\end{array}$

QUARTENARY

UPPER CRETACEOUS

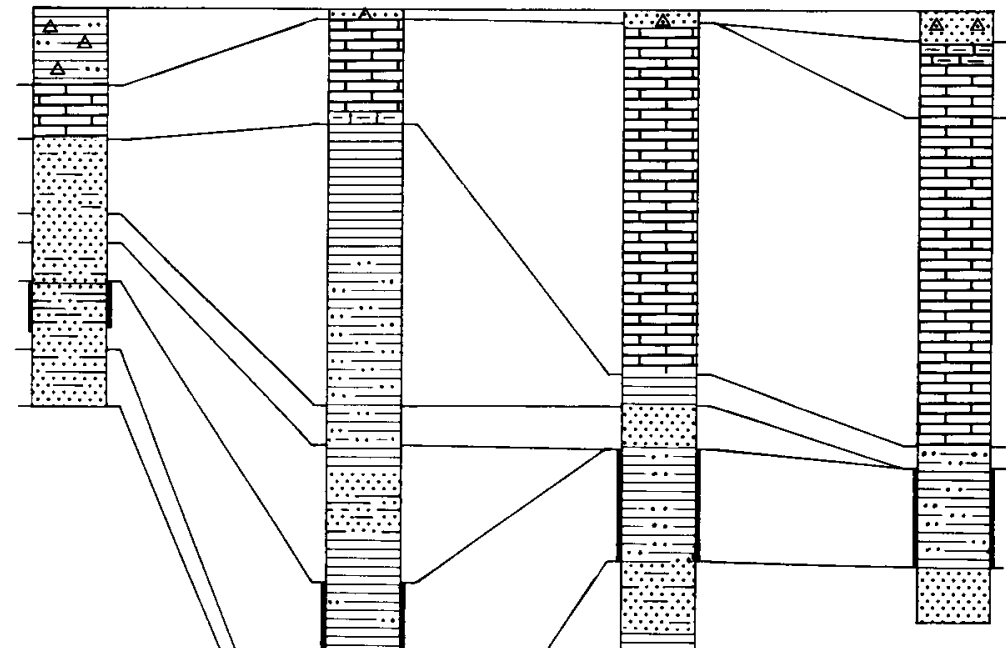

QUARTENARY

TERTIARY

LOWER CRETACEOUS

UPPER JURASSIC

MIDDLE JURASSIC

LOWER JURASSIC

UPPER TRIASSIC

\section{LEGEND:}

Limestone

Maristone

Claystone

Sand- or siltstreaked, claystone

Claystreaked, silt- or sandstone

Sandstone

77 Rocksalt

$\Delta$ Quartenary deposits

I Sequences referred to the

Fjerritslev Formation

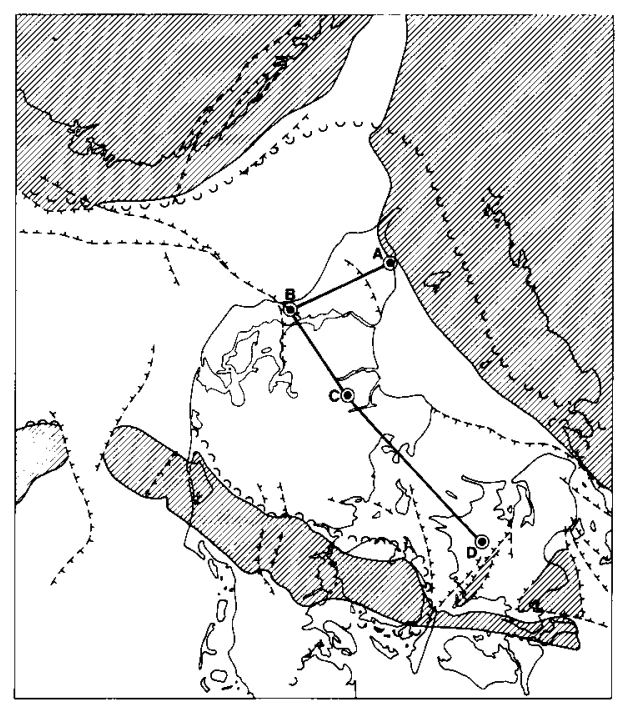

LOWER TO MIDDLE TRIASSIC

UPPER PERMIAN

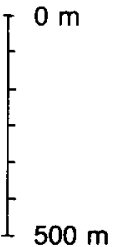

LOWER CRETACEOUS

LOWER JURASSIC

UPPER TRIASSIC

Fig. 3. The sequence in the four investigated boreholes, after Larsen (1966), Well Data Summary Sheets (1981), and Frandsen (1988). The extent of the Fjerritslev Formation in the individual boreholes is emphasized. The chronostratigraphy shown is based on Sorgenfrei \& Buch (1964), Michelsen (1975), and this study.

IV), and further subdivided the F-I member into two subunits, F-Ia and F-Ib, based on petrophysical logs. Michelsen (1989) subsequently elevated these two subunits to the rank of members, and redescribed the resultant five (informal) members of the Fjerritslev Formation, adopting the Hyllebjerg-1 borehole as a reference section.

The formation comprises marine sediments dominated by dark greyish mudstone and silt-streaked mudstone. Intercalated coarse grained siltstone and fine- grained sandstone are present, and sideritic clay-ironstone concretions are common (Michelsen 1978, 1989, Pedersen 1983, 1985, 1986).

The five members of the Fjerritslev Formation are distinguished by their log signature, their lithology, and sedimentary structures (see further discussion on $\mathbf{p}$. 11-12).

The Fjerritslev Formation is widely distributed in the Danish Subbasin. In the Danish Central Trough it is found only in the Salt Dome Province. Clay sequences 
of equivalent age in the Norwegian sector of the North Sea have also been assigned to the Fjerritslev Formation (Vollset \& Doré 1984). Lower Jurassic deposits of comparable lithology are found farther north in the Norwegian and British sectors (Dunlin Group, Vollset \& Doré 1984), in the southern part of the British sector (Lias Group, Rhys 1974) and in the Dutch sector (Aalburg Shale Formation, Posidonia Shale Member, NAM \& RGD 1980) (Michelsen, Frandsen, Holm, Jensen, Møller \& Vejbæk 1987). The maximum thickness of the Fjerritslev Formation observed in borings (911m) occurs in the type section, the Fjerritslev-2 borehole. The formation is much thinner in the marginal parts of the basin, e.g. $173 \mathrm{~m}$ in the Frederikshavn-2 borehole (see figs 2 and 3 ).

In the Danish Subbasin, the Fjerritslev Formation overlies a deltaic to littoral succession, the Gassum Formation (defined in the Gassum-1 borehole by Larsen (1966), amended by Bertelsen (1978)). In northern and western parts of the Subbasin the Fjerritslev Formation is overlain unconformably by the deltaic Haldager Sand Formation (Michelsen 1989), and in the southeast (e.g. in the Stenlille-2 and Slagelse-1 boreholes) by the Lower Cretaceous Vedsted and Rødby Formations respectively (Michelsen 1978, Frandsen 1988).

\section{Bio- and chronostratigraphy}

Nørvang (1957) investigated the foraminiferal faunas in the Lower Jurassic sequences of 9 Danish boreholes, including Frederikshavn-2 and Gassum-1.

Sorgenfrei and Buch (1964) presented a chronostratigraphical subdivision of 31 Danish boreholes, including Fjerritslev-2, Frederikshavn-2, and Gassum-1, based on palaeontological, lithological, and geophysical studies by Frebold (1948), Norwood et al. (1951), Gregersen \& Sorgenfrei (1951), and the study by Nørvang (1957).

Michelsen (1975) studied the ostracod faunas in the Lower Jurassic sequences of 36 Danish boreholes, (including the three mentioned above). He presented a biostratigraphical zonation of the investigated sequences and proposed a chronostratigraphical subdivision by correlation with ostracod-zoned and ammonitedated sequences from northern Germany. The chronostratigraphical subdivisions of the Fjerritslev-2, Frederikshavn-2, and Gassum-1 boreholes shown in figs 3, 7, 8 and 10 are based on the work of Sorgenfrei and Buch (1964) and Michelsen (1975). The ostracod zonation proposed by Michelsen (1975) is shown in fig. 6 .

The subdivision of the Jurassic used in this paper follows that of Harland et al. (1989). This subdivision differs from that adopted by Michelsen $(1975,1978)$ in two ways: 1) Michelsen referred the Aalenian to the Early Jurassic, whereas Harland et al. refer it to the
Middle Jurassic. 2) Michelsen used the ammonite zone Caenisites turneri to define the earliest part of the Late Sinemurian, whereas this zone was used by Harland et al. (1989) to define the latest Early Sinemurian.

The subdivision by Michelsen (1975) of the sequence from the FJERRITSLEV-2 BOREHOLE (fig.7) was based partly on lithology and partly on a relatively poor ostracod fauna. The Triassic-Jurassic boundary was placed, entirely on lithological evidence, at $2300 \mathrm{~m}$ b.r.t. The Lower-Upper Sinemurian boundary was placed, on the basis of ostracods, between $2084 \mathrm{~m}$ and $2004 \mathrm{~m}$ b.r.t. The Lower-Upper Pliensbachian boundary was placed at $1793 \mathrm{~m}$ b.r.t. on the basis of the presence of the ostracod species Ogmoconchella danica at this level. The core from $1564 \mathrm{~m}$ to $1561 \mathrm{~m}$ b.r.t. was referred to the Upper Pliensbachian. No ostracods were recorded above this level. However, lithological correlation with the Vedsted-1 borehole (where ostracods were recorded from the uppermost part of the Fjerritslev Formation) points to an Early or earliest Middle Jurassic (Aalenian) age for the uppermost part of the formation.

Michelsen's $(1975,1978)$ subdivision of the Lower Jurassic sequence in the FREDERIKSHAVN-2 BOREHOLE (fig. 8) was based partly on a relatively poor ostracod fauna and partly on lithology. The location of the Triassic-Jurassic boundary at about $883 \mathrm{~m}$ b.r.t. (Michelsen 1975, text fig. 3) is probably erroneous. This level is the boundary between the Gassum and Fjerritslev Formations, which does not coincide with the Triassic-Jurassic boundary in the Frederikshavn- 2 borehole. The Triassic-Jurassic boundary should probably be located within the Gassum Formation, in accordance with observations from the Flyvbjerg-1 borehole (Olaf Michelsen, pers. comm. 1989).

The position of the Upper Sinemurian-Lower Pliensbachian boundary is based on ostracods and located in a gap in core coverage between $879 \mathrm{~m}$ and $855 \mathrm{~m}$ b.r.t. (see fig. 8). The Lower-Upper Pliensbachian boundary is located at $783 \mathrm{~m}$ b.r.t. on the basis of the ostracod fauna. The boundary between the Lower and Middle Jurassic was placed at $731 \mathrm{~m}$ b.r.t. As Michelsen (1975) included Aalenian in the Early Jurassic Epoch, the uppermost part of the sequence referred to the Early Jurassic could be of Aalenian (earliest Middle Jurassic) age.

The chronostratigraphic subdivision of the Fjerritslev-2 and Frederikshavn-2 boreholes, presented by Sorgenfrei and Buch (1964) is less detailed than, but comparable with, Michelsen's (1975) subdivision.

The chronostratigraphical subdivision of the STENLILLE-2 BOREHOLE (fig. 9) is based on unpublished preliminary results from ostracod and palynomorph investigations of the Stenlille-1 borehole (Michelsen 1980, Hansen 1981), correlated to Stenlille-2 using petrophysical logs (Frandsen 1988).

The positioning of the chronostratigraphic bounda- 
ries in the GASSUM-1 Lower Jurassic sequence (Sorgenfrei \& Buch 1964, Michelsen 1975) was discussed by Dybkjær (1988, p. 8) and is shown in fig. 10.

The Upper Triassic to Lower Jurassic sequence in the Gassum-1 borehole has been the object of earlier palynological studies, probably because of the atypically close coring. Bertelsen (1978) dated the uppermost part of the Gassum Formation and the lowermost part of the Fjerritslev Formation as Rhaetian to Hettangian. Dybkjær (1988) defined and dated three spore/pollen zones in the uppermost Triassic to Lower Jurassic sequence in Gassum-1: Zone A (1538m to $1533 \mathrm{~m}$ b.r.t.), Rhaetian; Zone B (1515m to $1463 \mathrm{~m}$ ), Hettangian; and Zone C $(1454 \mathrm{~m}$ to $1209 \mathrm{~m})$, Early Sinemurian to ?Pliensbachian/Toarcian.

Michelsen $(1973,1975,1978)$ demonstrated that the boundary between the Gassum and Fjerritslev Formations is diachronous. According to Michelsen (1975) this lithostratigraphic boundary coincides with the Triassic-Jurassic boundary in the central and southern part of the basin but in the northern and eastern parts of the basin it is of Late Sinemurian age.

The age of the members of the Fjerritslev Formation, according to Michelsen (1978, fig. 3), are as follows:

$\begin{array}{ll}\text { F-Ia member: } & \text { Hettangian to Early Sinemurian } \\ \text { F-Ib member: } & \begin{array}{l}\text { Late Sinemurian to earliest Early } \\ \text { Pliensbachian }\end{array} \\ \text { F-II member: } & \begin{array}{l}\text { Early Pliensbachian to middle Late } \\ \text { Pliensbachian }\end{array} \\ \text { F-III member: } & \begin{array}{l}\text { middle Late Pliensbachian to Toar- } \\ \text { cian }\end{array} \\ \text { F-IV member: } & \text { (?latest Toarcian to) Aalenian }\end{array}$

The early Middle Jurassic Mid-Kimmerian tectonic phase has important implications for the correlation of the Lower Jurassic sequences in the Danish Subbasin. During this tectonic episode the Ringk øbing-Fyn High was uplifted, resulting in the absence of Upper Triassic to lowermost Upper Jurassic strata on the high and along its margins (Michelsen 1978, Michelsen \& Bertelsen 1979, Ziegler 1982). In combination with local salt-movements, this uplift may have produced the uppermost Lower Jurassic to lowermost Upper Jurassic hiatus in the Gassum-1 borehole (Sorgenfrei \& Buch 1964, Larsen 1966). According to Frandsen (1988), an even longer hiatus, from the Lower Jurassic to Lower Cretaceous, is present in the Stenlille-2 borehole. No significant hiati were recorded from the Lower Jurassic in the Fjerritslev-2, and Frederikshavn-2 boreholes (Michelsen 1978).

\section{Depositional environment}

The Danish Subbasin existed as a major area of deposition and subsidence from the Late Permian to the Late Cretaceous. It is bordered to the north and east by the Fennoscandian Shield, and to the south it is separated from the North German Basin by the Ringkøbing-Fyn High (figs 1 and 2).

The distribution of sedimentary facies within the $\mathrm{Ju}$ rassic was controlled primarily by eustatic changes in sea-level and fault-controlled subsidence (Hallam 1978, 1981, Hallam \& Bradshaw 1979, Rolle, Koch, Frandsen \& Surlyk 1979, Surlyk, Clemmesen \& Larsen 1981).

The fine-grained clastic shelf sediments of the Fjerritslev Formation were derived from the Fennoscandian Shield, and probably transported into the basin by numerous small rivers (Larsen 1966).

Deposition of the Fjerritslev Formation started in the southern and central parts of the Danish Subbasin as the result of a global rise in sea level during Rhaetian to Hettangian times. Deltaic and littoral conditions prevailed to the northeast, in northern Jutland, and to the southeast, in the Danish-Polish Trough, until Late Sinemurian times when the Fjerritslev Formation succeeded the Gassum Formation in those areas. During deposition of the Fjerritslev Formation, the depocentre shifted eastwards from northwest Jutland to east of the Fjerritslev Fault (Michelsen 1975, 1978).

A warm and humid climate is indicated by the dominance of kaolinite in the clay minerals of the Fjerritslev Formation (Schmidt 1985a). According to Hallam (1985) the Early Jurassic climate in the region was subtropical to warm temperate, and "seasonally wet".

\section{Environmental interpretation of the Gassum-1 section}

The depositional environment of the Fjerritslev Formation has been determined from detailed lithological, palaeontological and palynological investigations (Michelsen 1975, Pedersen 1986, Dybkjær 1988).

Michelsen (1975) studied the diversity and density of the Lower Jurassic ostracod faunas in the Gassum-1 borehole. The results are shown here in fig. 18 .

The effects of the major "pulses" of sea-level rise during the Early Jurassic transgression have been studied by Pedersen (1986) and Dybkjær (1988). According to Hallam (1981) major "pulses" in sea-level rise occurred in the earliest Hettangian, the Early Sinemurian, the Late Sinemurian to Early Pliensbachian, the Late Pliensbachian and the Early Toarcian (see fig. 19). These regional, eustatic phases of sea level rise are recognizable both in the sedimentary sequences along the margin of the Danish Subbasin, and as minor lithological changes in the central parts of the basin (Bertelsen 1978, Michelsen 1978, Pedersen 1983, 
1986). According to Pedersen (1986) an additional mid to late Sinemurian deepening event is recognizable in the Danish Subbasin.

Pedersen (1986) studied variations in the bivalve assemblages through the Fjerritslev Formation in Gassum-1 and compared the results with those from earlier studies of benthic foraminifera (Nørvang 1957) and ostracods (Michelsen 1975). The bivalve assemblages generally indicate an outer shelf depositional environment with normal salinities and normal to reduced levels of dissolved oxygen in the bottom waters.

A general upward decrease in the number of bivalve species, and a corresponding increase in the number of benthic foraminifera species (fig. 18; see also fig. 6, Pedersen 1986), were interpreted as indicating an increase in water depth related to the Early Jurassic transgression.

A distinct change in the bivalve assemblages from a "normal shale facies fauna" to a "restricted shale facies fauna" (Morris 1979, Pedersen 1986) was recorded in the Upper Sinemurian sequence (middle part of the F-Ib Member) (Pedersen 1986). The less diverse fauna is recorded throughout the Pliensbachian. The change was interpreted as a response to a reduction in the levels of dissolved oxygen in the bottom waters, probably related to the Late Sinemurian-Early Pliensbachian eustatic sea-level rise (Pedersen 1986). This change in the bivalve assemblages, close to the Sinemurian-Pliensbachian boundary, is contemporaneous with a distinct drop in the number of ostracod species and specimens, and a less pronounced decrease in the number of benthic foraminifera species (fig. 18; see also fig. 6, Pedersen 1986).

In the uppermost sample from the Fjerritslev Formation of Late Pliensbachian age, bivalves are totally lacking; the number of ostracod species decreases abruptly, but the number of benthic foraminifera species is relatively high. On the basis of the sparse benthic fauna and the occurrence of pyrite crystals on rare ostracod shells, Michelsen (1975) suggested that the environment was more reducing in nature. Pedersen (1986) related these observations to the initiation of the Early Toarcian deepening event. The observed faunal changes are not reflected by a significant lithological change.

Dybkjær (1988) interpreted the depositional environment of the Fjerritslev Formation in Gassum-1 on the basis of variations in the palynomorph assemblage. A dominance of terrestrial palynomorphs over marine palynomorphs throughout the formation confirmed earlier interpretations of a shelf environment. Minor variations between the main morphological groups of palynomorphs were recorded. Assumed minima of freshwater influence, recorded as maxima percentages of marine palynomorphs together with maxima of saccate pollen and minima of trilete spores, were recorded at four levels: 1) uppermost Rhaetian to lowermost
Hettangian, 2) Lower Sinemurian, 3) the sequence from $1402 \mathrm{~m}$ to $1341 \mathrm{~m}$ b.r.t., referable, according to Sorgenfrei \& Buch (1964), to the Upper Sinemurian, 4) the sequence $1341 \mathrm{~m}$ to $1280 \mathrm{~m}$ b.r.t., referable, according to Sorgenfrei \& Buch (1964), to the Lower to Upper Pliensbachian. These levels were regarded as reflecting the earliest four phases of eustatic sea-level rise in the Early Jurassic, as recognized by Hallam (1981). Furthermore, a less pronounced increase in the relative abundance of marine palynomorphs was recognized in the uppermost sample of the Fjerritslev Formation in the Gassum-1 sequence, immediately below the latest Pliensbachian-Late Jurassic hiatus. This increase was interpreted as reflecting the start of the Early Toarcian rise in sea-level.

\section{Depositional environment of the five members}

The depositional environment of the five members of the Fjerritslev Formation is discussed below. The account is based on earlier studies by Michelsen (1975, 1978, 1989), Pedersen $(1983,1985,1986)$, and Thomsen, Damtoft \& Andersen (1987). The environmental interpretations are shown in fig. 19. The stratigraphical and geographical distribution of each member is shown in Michelsen (1978, figs 12,13, 1989, figs 4,5) and Pedersen (1983, figs 21, 22, 23; 1986, fig. 7).

\section{F-Ia member:}

The transition from the relatively coarse-grained Gassum Formation to the black silty claystones of the Fjerritslev Formation occurs within a very narrow interval in the cores from the Stenlille- 1 and -2 boreholes, and is also evident on the petrophysical logs from several other boreholes. This transition is believed to correspond to the basal Hettangian transgression, probably caused by eustatic sea-level rise.

The F-Ia member is characterized by the greatest lithological variation encountered within the Fjerritslev Formation. The dominant lithologies are mudstone and silt-streaked mudstone interbedded with siltstone and limestone. The ostracod fauna shows increasing faunal density and diversity upwards, and the shells are well preserved. The depositional environment has been interpreted as shallow-water, well-oxidized, and with varying energy levels (Michelsen 1978).

\section{F-Ib member:}

This member comprises a relatively homogeneous dark grey mudstone. The ostracod faunal diversity and density are low, and the shells are poorly preserved. The member was probably deposited at greater depth, and 
farther offshore, than the F-Ia member; according to Michelsen (1975), reducing conditions prevailed.

The area of marine sedimentation expanded in the Late Sinemurian. During this time, the F-Ib member rapidly overstepped the Gassum Formation in the area north of the Fjerritslev Fault. According to Michelsen $(1975,1978)$ the Fjerritslev Formation did not overstep the Gassum Formation in the northernmost parts of the Danish Subbasin until the latest Sinemurian. This event which occurs during deposition of the middle part of F-Ib member, seems time-equivalent with the Late Sinemurian-Early Pliensbachian phase of eustatic sealevel rise.

\section{F-II member:}

The member consists of a laminated claystone with a relatively high sand and silt content. Numerous current and wave-generated structures are present. These suggest higher energy environments and shallower water depths than those of either F-Ib member or F-III member. The ostracod fauna is diverse and indicates a well oxygenated environment. The member has been recorded throughout the Danish Subbasin.

Petrophysical logs can be used to subdivide the member into three subunits which can be distinguished in several wells. This subdivision indicates that parts of the member (often the upper part) are locally missing. In the southern parts of the basin the top of the member is eroded and overlain unconformably by Middleand Upper Jurassic formations.

\section{F-III member:}

This member is characterized by mudstone, in places slightly silty, and showing only minor bioturbation, indicating deposition in a generally deeper and lower energy environment than the F-II member. Due to erosion in the eastern and southern parts of the Danish Subbasin, the member is now restricted to the central and northern parts.

The lower part of the F-III member is characterized by a relatively high ostracod faunal diversity and density, indicating a well-oxygenated sea-floor. However, the upper part of the sequence is barren of benthonic fossils, indicating increasingly reduced conditions in the bottom waters.

The reducing conditions in the upper part of F-III member could be a reflection of the Early Toarcian sea-level rise, as recognized by Hallam (1963, 1967, 1981, 1987) and Vail \& Todd (1981). This sea-level rise was accompanied by widespread deposition of anoxic shale facies throughout northwestern Europe, including the German Posidonia Shale (e.g. Seilacher 1982,
Wille 1982, Riegel, Loh, Maul \& Prauss 1986) and the Jet Rock of the British Jurassic (Hallam 1967, 1978, Morris 1980).

\section{F-IV member:}

This unit is generally coarser-grained than the F-III member. It is dominated by mudstone but includes siltstone and sandstone laminae, locally carbonate-cemented.

Based on the ostracod fauna, Michelsen (1978) interpreted the depositional environment as lagoonal, with strongly reducing conditions in the bottom waters. In the cores studied by Pedersen (1983), however, there is no direct evidence in either the trace fossil assemblage or the sedimentary facies for either a lagoonal environment or reducing conditions. A core referred to the F-IV member from the Fars $\varnothing-1$ borehole contains numerous burrows that are indistinguishable from trace fossils observed in the other fully marine members of the Fjerritslev Formation.

\section{Organic matter}

The amount, type and maturity of organic matter in the Fjerritslev Formation have been investigated by Lindgren \& Thomsen (1982), Thomsen, Lindgren \& Wrang (1983), Schmidt (1985b), Thomsen et al. (1987), and Damtoft, Andersen \& Thomsen (1987).

The Total Organic Carbon content (T.O.C.) of this formation generally lies between 0.9 and $1.6 \%$ in the Danish Subbasin (Schmidt 1985b, Thomsen et al. 1987), but the open-marine shales of the Fjerritslev Formation in the Salt Dome Province of the Danish Central Trough contain an average of $2.1 \%$ T.O.C. (Damtoft et al. 1987).

The organic material is generally dominated by terrestrially-derived particles (Lindgren \& Thomsen 1982, Schmidt 1985b), but significant variations have been recorded from borehole to borehole (Thomsen et al. 1987). The F-Ia, F-Ib and F-II members of the Fjerritslev Formation were deposited under generally oxic conditions and are dominated by highly oxidized gasprone Type III kerogen (see definition of kerogen types in Tissot, Durand, Espitalié \& Combaz (1974) and Tissot \& Welte (1984)). The change towards more reducing conditions during deposition of the F-III and F-IV members is reflected by the presence of significant amounts of Type II-III and Type II kerogens. Significant variations in the quality of the hydrocarbon source-rock have, however, been recorded from borehole to borehole. These lateral variations were thought to reflect local facies control, which could have been caused by salt-induced movements producing local ba- 
sin and swell topography. Anoxic conditions could thus have developed locally in rim-synclines (Thomsen et al. 1987).

The organic matter from the Fjerritslev Formation is generally immature with respect to hydrocarbon generation (Schmidt 1985b, Thomsen et al. 1983, 1987). According to Thomsen et al. (1983), the Thermal Alteration Index (T.A.I.) for the Rhactian-Jurassic-Early Cretaceous deposits in the Danish Subbasin ranges between 1 and $2+$ (using a modified version of the scales published by Staplin (1969) and Burgess (1974), with a scale ranging from 1 to 5 , corresponding to the one used in the present study). Thomsen et al. (1983) observed an increase in maturity of the organic matter towards the centre of the Subbasin, reflecting increasing depth of burial. The lowest maturity values, indicating shallow burial, were encountered towards the Fennoscandian Border Zone and the RingkøbingFyn High. 


\section{Materials and methods}

\section{Sampling}

The study was based on 120 conventional core samples, 16 sidewall core samples, and 84 cuttings samples. The material from the Fjerritslev-2, Frederikshavn-2, and Gassum-1 boreholes was made available by the Geological Survey of Denmark, and that from the Stenlille- 2 borehole was provided by Dansk Olie \& Gasproduktion $\mathrm{A} / \mathrm{S}$. Regularly spaced samples were taken from the cored intervals, or selected from sidewall cores or cuttings where conventional cores were not available. All significant lithological variations observed in the cores were sampled; representative cuttings material was selected on the basis of size and coherency.

\section{Palynological preparation}

The technique adopted was that used in the preparation of material from the Gassum-1 borehole (Dybkjær 1988).

About $4 \mathrm{~g}$ of material were processed from each of the core and sidewall core samples. $2-4 \mathrm{~g}$ samples were taken from cuttings material, depending on the availability of suitable fragments. In order to remove surficial drilling mud contamination, cuttings were carefully washed with distilled water. All samples were subsequently processed using an identical procedure: $10 \%$ $\mathrm{HCl}\left(30 \mathrm{~min}\right.$ to 24 hours), $40 \% \mathrm{HF}\left(100^{\circ} \mathrm{C}, 2 \times 2\right.$ hours $)$, $10 \% \mathrm{HCl}\left(100^{\circ} \mathrm{C}, 30 \mathrm{~min}\right)$, followed by washing in distilled water.

Prior to further treatment (including oxidation or sieving) one or two slides of the total assemblage of organic matter ("kerogen") in each sample were made.

The remaining residue was subsequently sieved through a 10 micron mesh nylon filter and temporary water-suspended mounts examined under the microscope. All samples were then treated with nitric acid (HNO3) $(65 \%)$ for one minute in order to remove concentrations of pyrite (especially common within the sacci of bisaccate pollen grains). The samples were then washed with distilled water on a 10 micron mesh filter.

Heavy liquid separation was found to be necessary because of the amount of mineral matter that had survived $\mathrm{HCl}$ and $\mathrm{HF}$ treatment. Zinc chloride (specific gravity $1.9 \mathrm{~g} / \mathrm{cm}^{3}$ ) was added to the residue, which was then thoroughly stirred and centrifuged. The super- natant portion containing the organic matter was decanted, and fresh $\mathrm{ZnCl}_{2}$ added to the remaining portion which was re-stirred and re-centrifuged. This procedure proved very effective. The $\mathrm{ZnCl}_{2}$ containing the heavy fraction was examined prior to disposal to check for any potential loss of organic material. The residues were finally washed with distilled water on a 10 micron mesh filter to remove any traces of chemicals. Two to four glycerine-mounted slides were prepared for each sample.

\section{Total organic carbon (T.O.C.) measurements}

The total content of organic carbon (weight percent) of all core samples and sidewall core samples was measured at the Geological Survey of Denmark.

A minimum of $1 \mathrm{~g}$ of material from each sample was crushed to a maximum grain-size of 250 microns; 200 $\mathrm{mg}(+1-0.5 \%)$ of the pulverized sample was placed in a crucible. A few drops of ethanol were added, followed by ten drops of concentrated hydrochloric acid $(\mathrm{HCl})$, and the compound was heated to about $120^{\circ} \mathrm{C}$ for 30 minutes. After cooling, the $\mathrm{HCl}$ treatment was repeated twice to ensure removal of carbon bonded as carbonate. The sample was placed overnight in an oven at a temperature of $120^{\circ} \mathrm{C}$. The organic carbon content was then measured in a LECO oven (IR-212 carbon 784-400 System). The crucible containing the dry, acidtreated sample was placed in the oven which was heated to $2000^{\circ} \mathrm{C}$; oxygen was added to ensure complete combustion of the organic material. Evolved $\mathrm{CO}_{2}$ was measured and converted into weight percent organic carbon. The results are presented in appendix A to $\mathrm{E}$, and in figs 12, 14, 16 and 18.

\section{Thermal Alteration Index (T.A.I.)}

The colour of organic material changes from bright yellow to brown and black with increasing thermal alteration (e.g. Schopf 1948, Correia 1967, Burgess 1974, Combaz 1975, Staplin 1969, 1977). Several indices and scales for thermal alteration of organic sedimentary particles have been presented, e.g. Staplin (1969), Burgess (1974), Dow (1977), and Batten (1980, 1981, 1982).

Response to thermal alteration varies with the type 
of kerogen particles. Generally the colours of spores and pollen, particularly unornamented species, are considered to be the most sensitive and reliable indicators of maturity, especially at the immature end of the thermal scale; dinoflagellate cysts tend to be less reliable (Staplin 1969, Batten 1981, Venkatachala 1981a).

In the present study a pollen/spore colour standard card (produced by D.L. Pearson, Phillips Petroleum Company) was used. The colour scale is correlated to a T.A.I. scale with values from 1 to 5 , subdivided into a total of 11 categories. The use of a standard colour scale ensured an objective and uniform T.A.I. determination throughout the study.

The T.A.I. values were determined on the basis of one specific spore species, Deltoidospora toralis (Leschik 1955) Lund 1977. This species is well suited for this purpose, being well-represented in nearly all studied samples, and having a relatively thin, unsculptured exine. T.A.I. values were determined for every specimen of Deltoidospora toralis observed during counting of palynomorphs for biostratigraphical purposes. The results are presented in fig. 21.

\section{Microscopic examination and counting}

The most suitable samples and slides were chosen for counting by examination under a Leitz Wetzlar light microscope. They were selected to provide a representative distribution of biostratigraphical and palynofacies observations, and to take into account all the major lithological variations present in the sequence. Some of the samples are barren of palynomorphs, and were thus only used for counting kerogen particles. The location of the samples chosen for counting are shown in figs. 7-10. A general lithological description of each sample is given in appendices A-D.

\section{Biostratigraphical counting}

Biostratigraphical counting was carried out in preparations from both core and cuttings samples. The counting was carried out at a magnification of $\mathrm{x} 400$, and at least 250 miospores were recorded for each sample (independently of the number of aquatic palynomorphs). These counts were used to determine the percentage composition of the palynomorph assemblage. The remainder of the slide (and in the case of a sparse assemblage, a second slide) was then thoroughly examined in order to assess the total diversity of the assemblage present. Additional species observed during this procedure were recorded as " $<1 \%$ " (see range-charts, tables $1-6$ ).

\section{Counting of kerogen particles}

Counting of kerogen particles was only performed on core and sidewall core samples, as it is generally impossible to discriminate between caved and in situ kerogen particles. Furthermore, biostratigraphical evidence clearly indicated caving in several of the cuttings samples (particularly those from the Frederikshavn-2 borehole).

At least 500 particles were counted in each sample. The counting was carried out at a magnification of $x 250$ and the results were used to determine the percentage composition of the kerogen assemblage (see table 7 for the categorization of the kerogen particles). The whole slide was scanned in order to provide a qualitative assessment of the degree of sorting and state of preservation of the palynomorphs. The results are presented in appendix A to E, and in figs 12, 14, 16 and 18.

The slides counted from the Gassum-1 borehole were those used in the earlier biostratigraphical study by Dybkjær (1988), together with a few additional slides from samples that were barren of palynomorphs. 


\section{The biostratigraphical investigation}

\section{Introduction}

Although the palynology of the Early Jurassic Epoch has been studied by a number of workers, erection of a detailed spore/pollen zonation for the NW European region has not proved successful (see for example the zonations in fig. 6). The reason for this is probably that floral evolution during the Early Jurassic was slow and gradual, and that the dominant spore/pollen species ranged throughout that epoch.

A combination of a spore/pollen zonation and a dinoflagellate cyst zonation turned out to be very useful in the study reported here. The use of dinoflagellate cysts made the resulting zonation and dating more detailed than would have been possible using only the spores and pollen.

The use of dinoflagellate cysts in the zonation of Lower Jurassic sequences is a relatively new approach (Williams 1977, Morbey 1978, Woollam \& Riding 1983). This fossil-group seems to have some advantages compared with the miospore-group:

1) the single species often appear in large numbers

2) they generally show limited, and well-defined ranges

3) both their first and last appearances are used as stratigraphically important events.

The only clear disadvantage is that they are essentially restricted to marine sediments.

\section{Results of the biostratigraphical counting}

The results of the biostratigraphical counting are shown in the range-charts (tables 1-6). All recorded "in situ" species are mentioned in the systematic section, including comments on some species. The studied sequences generally contained a moderately preserved and diverse assemblage of spores, pollen and aquatic palynomorphs. Evidence of reworking is only sporadic, while caving turned out to be a general feature in the cuttings samples, especially in the Frederikshavn-2 borehole. Caving in the cuttings samples from the Fjerritslev-2 and Stenlille-2 boreholes was not recorded with certainty.

\section{Records of reworked palynomorphs}

Reworked Carboniferous spores are well known from Upper Triassic and Jurassic sequences in the Danish area and adjacent regions: from the Rødby- 1 borehole (Lund 1977), from several boreholes in NW Scania (Guy-Ohlson, Lindqvist \& Norling 1987), and from Lower to Middle Jurassic sequences on Bornholm (Hoelstad 1985, Nielsen \& Koppelhus 1991).

Presumed reworked Carboniferous spores were recorded sporadically in the present study. The recorded spores were referred to the genera Lycospora Schopf, Wilson \& Bentall 1944 emend. Potonié \& Kremp 1954, Densosporites Berry 1937 emend. Potonié \& Kremp 1954 (several specimens), Platyptera Naumova 1934 ex. Naumova 1938, and Murospora Somers 1952. Most of the specimens are corroded, and show a darker colour than the "in situ"-palynomorphs, but others are rather well preserved.

Two reworked acritarchs were also recorded. One was referred to the species Diexallophasis denticulata (Stockmans \& Williére 1963) Loeblich 1970 and the other to the genus Multiplicisphaeridium Staplin 1961 emend. Staplin, Jansonius \& Pocock 1965. Both types are known from Silurian and Devonian strata in North America and Europe.

Reworking of material from other levels was not recorded with certainty.

\section{Records of caved palynomorphs}

Spores, pollen and dinoflagellate cysts assessed as caved were recorded from several cuttings samples, especially from the Frederikshavn-2 borehole.

Among the presumed caved dinoflagellate cyst species are: Odontochitina operculata (Wetzel 1933) Deflandre \& Cookson 1955, Sirmiodinium grossii Alberti 1961 emend. Warren 1973, Kleithriasphaeridium readei (Davey \& Williams 1966) Davey \& Verdier 1976, Spiniferites ramosus (Ehrenberg 1838) Loeblich \& Loeblich 1966, and Protoellipsodinium spinosum Davey \& Verdier 1971.

Presumed caved spores and pollen include the following: Concavissimisporites variverrucatus (Couper 1958) Brenner 1963, Foveosporites labiosus Singh 1971, 
Clavifera triplex (Bolchovitina 1953) Bolchovitina 1966, Cicatricosisporites hallei Delcourt \& Sprumont 1955, Gleicheniidites cf. bulbosus Kemp 1970, Parvisaccites radiatus Couper 1958, and Contignisporites glebulentus Dettmann 1963 emend. Filatoff \& Price 1988.

Gleicheniidites senonicus Ross 1949 is very common in Lower Cretaceous strata. This species was recorded sporadically from core-samples referred to the Early and Middle Jurassic in the present study (see discussion in the systematic section). The high relative abundance of this species recorded in samples Frh-18,s and Frh-20,s, however, is probably due to caving, as high relative abundances of this species are only known from Lower Cretaceous strata.

All these spore/pollen species, except Contignisporites glebulentus, have been recorded from the Lower
Cretaceous sequence in the Frederikshavn-1 borehole (Elly Andersen, pers. comm., 1988). Furthermore, the mentioned dinoflagellate cyst species as well as the spores and pollen, are generally known as Early Cretaceous types (see Couper 1958, Döring 1965, 1966, Kemp 1970, Dörhöfer 1977, 1979, Heilmann-Clausen 1987). If the terrestrial and marine palynomorphs are presumed to originate from the same level, their common occurrence indicates a possible age range from the Barremian to immediately above the Aptian-Albian boundary. The age is limited (downwards) by the occurrence of Odontochitina operculata, and (upwards) by Sirmiodinium grossii (see the range of these species in northwestern Europe in Heilmann-Clausen (1987, fig.4). 


\section{Systematics}

All palynomorph taxa presumed to be "in situ", or to be reworked from older strata, are listed in this section. Species that are presumed to be caved (see p. 16) are not considered here, while species which may be caved, but which are known to occur sporadically in Lower Jurassic deposits, are included.

Taxonomic references to genera and higher taxa are not included but are given by Dettmann (1963). Only synonyms from the most important references are presented.

The holotypes of species marked with an asterisk have been investigated by the author. New photographs of these holotypes are presented on plates 21 and 22.

The orientation of the grains when measuring their size is in accordance with Schulz (1967, text fig. 1). The stated total dimensions include sculptural elements. Where more than one specimen has been measured, the minimum value (a), mean value (b), and maximum value (c) are stated as follows: a (b) c (n specimens).

\section{Spores and pollen}

Anteturma Sporites H. Potonié 1893

Turma Triletes (Reinsch 1881) Dettmann 1963

Subturma Azonotriletes (Luber 1937) Dettmann 1963

Infraturma Laevigati (Bennie \& Kidston 1886) R. Potonié 1956

Genus Deltoidospora Miner 1935 emend. Danzé-Cor$\sin \&$ Laveine 1963

Deltoidospora toralis (Leschik) Lund

Pl.1, fig. 1

1955: Laevigatisporites toralis - Leschik, p.12; pl.1, figs 1, 2.

1958: Concavisporites toralis (Leschik 1955) - Nilsson, p.34; pl.1, figs 12,13 .

1977: Deltoidospora auritora (Reinhardt 1962) - Lund, p.50; pl.1, fig. 5 .

1977: Deltoidospora toralis (Leschik 1955) - Lund, p.49; pl.1, figs 2, 3.

Remarks: This species was used to estimate the "Thermal Alteration Index" (T.A.I.), see p. 14.

\section{Deltoidospora minor (Couper) Pocock}

Pl.1, fig. 2

1953: Cyathidites minor - Couper, p.28; pl.2, fig. 13.

1970: Deltoidospora minor (Couper 1953) - Pocock, p.28; pl.5, fig. 3 .
Remarks: This species differs from Deltoidospora toralis in having no proximal kyrtome, and from Deltoidospora australis in having a spore-diameter $<57 \mathrm{mi}-$ crons (Couper 1953).

Deltoidospora cf. minor (Couper) Pocock

Pl.1, fig. 3

Description: Trilete spore with a triangular amb, straight to slightly concave or convex sides and slightly pointed angles. The trilete mark has a distinct labrum, the sutures are more or less sinuous, and extend for $3 / 4$ to $4 / 5$ of the spore radius. The exine is laevigate, 1-2 microns thick.

Equatorial diameter: 21 (23) 25 microns (3 specimens) Remarks: These specimens differ from Deltoidospora minor (Couper 1953) Pocock 1970 in having pointed angles, sinuous sutures, a slightly thicker exine, and a smaller size.

\section{Deltoidospora australis (Couper) Pocock}

1953: Cyathidites australis - Couper, p.27; pl.2, fig. 11.

1970: Deltoidospora australis (Couper 1953) - Pocock, p.27.

\section{Genus Cibotiumspora Chang 1965}

\section{Cibotiumspora jurienensis (Balme) Filatoff}

Pl.1, fig. 4

1957: Concavisporites jurienensis - Balme, p.20; pl.2, figs 30, 31 .

1958: Auritulina intrastriatus - Nilsson, p.36; pl.1, fig. 17.

1975: Cibotiumspora jurienensis (Balme 1957) - Filatoff, p.61; pl.10, figs 8-13.

Genus Tripartina Maljavkina 1949 emend. Potonié 1960

Tripartina variabilis Maljavkina

Pl.1, fig. 5

1949: Tripartina variabilis - Maljavkina, p.49; pl.7, fig. 11.

Remarks: Differs from Deltoidospora cf. minor in having narrow, sinuous channels at the proximal surface, perpendicular to the rays of the trilete mark.

\section{Genus Intrapunctisporis Krutzsch 1959}

Intrapunctisporis toralis (Leschik) Lund Pl.1, figs. 6, 7

1955: Punctatisporites toralis - Leschik, p.19; pl.2, fig. 11.

1977: Intrapunctisporis toralis (Leschik 1955) - Lund, p.51; pl.1, fig. 8. 
Genus Punctatisporites Ibrahim 1933 emend. Potonié \& Kremp 1954

Punctatisporites globosus (Leschik) Lund Pl.1, fig. 8

1955: Laevigatisporites globosus - Leschik, p.11; pl.1, fig. 5

1958: Todisporites minor - Couper, p.135; pl.16, figs 9, 10.

1977: Punctatisporites globosus (Leschik 1955) - Lund, p.52; pl.1, fig. 11.

Punctatisporites major (Couper) Kedves \& Simoncsics

1958: Todisporites major - Couper, p.134; pl.16, figs 6-8.

1964: Punctatisporites major (Couper 1958) Kedves \& Simoncsics, p.13; pl.3, figs 1,2 .

\section{Genus Retusotriletes Naumova 1953}

\section{Retusotriletes mesozoicus Klaus}

1960: Retusotriletes mesozoicus - Klaus, p.120; pl.28, fig. 6.

\section{Retusotriletes cf. mesozoicus Klaus}

Pl.1, fig. 9

Remarks: Only one specimen recorded. This specimen only differs from Retusotriletes mesozoicus Klaus 1960 in being distinctly larger. The recorded specimen is 75 microns in spore-diameter, while the size-range for $R e$ tusotriletes mesozoicus was given as $35-55$ microns (Klaus 1960).

Genus Calamospora Schopf, Wilson \& Bentall 1944

Calamospora tener Leschik emend. Mädler

Pl.1, fig. 10

1955: Laevigatisporites tener - Leschik, p.13; pl.1, fig. 20.

1964b: Calamospora tener Leschik 1955 emend. Mädler, p.92; pl.8, fig. 2.

\section{Calamospora sp. 1}

Remarks: Identical to Calamospora tener apart from a thicker exine (about 1 micron), resulting in less tendency to folding. See photograph in Dybkjær (1988, pl.1, fig. 11, Calamospora sp.).

\section{Genus Stereisporites Pflug 1953}

Stereisporites stereoides (Potonié \& Venitz) Pflug Pl.1, fig. 11

1934: Laevigatisporites stereoides - Potonié \& Venitz, p.11; pl.1, figs 4,5 .

1953: Stereisporites stereoides (Potonié \& Venitz 1934) - Pflug, in Thomson \& Pflug (1953), p.53; pl.1, figs 64-73.

Stereisporites antiquasporites (Wilson \& Webster) Dettmann

Pl.1, fig. 12

1946: Sphagnum antiquasporites - Wilson \& Webster, p.273; fig. 2. 1963: Stereisporites antiquasporites (Wilson \& Webster 1946) - Dettmann, p.25; pl.1, figs 20, 21.
Stereisporites punctus (Klaus) Krutzsch

Pl.1, figs 13, 14

1960: Distalanulisporites punctus - Klaus, p.133; pl.28, fig. 8 .

1963: Stereisporites (Distalanulisporites) punctus (Klaus 1960) Krutzsch, p.19.

\section{Stereisporites cicatricosus (Rogalska) Schulz}

1954: Sporites cicatricosus - Rogalska, p.44; pl.12, fig. 11.

1967: Stereisporites (Rogalskaisporites) cicatricosus (Rogalska 1954) - Schulz, p.557; pl.1, figs 8, 9.

Stereisporites aulosenensis (Schulz) Schulz

Pl.2, fig. 1

1966: Stereisporites (Sculptisporis) aulosenensis (Schulz 1967) Schulz, p.77; pl.3, figs. 4-6.

1967: Camarozonosporites (Camarozonosporites) aulosenensis Schulz, p.573; pl.7, figs 12-14.

Remarks: This species differs from Stereisporites hauterivensis Schulz 1966 in having a thinner exine, a larger, more rugulate sculpturing, and a larger size.

Stereisporites cf. seebergensis Schulz Pl.2, fig. 2

Remarks: These specimens differ from Stereisporites seebergensis, originally described by Schulz (in Döring, Krutzsch, Schulz \& Timmermann (1966)), in having a thinner exine, and a less distinct curvatura perfecta.

\section{Stereisporites hauterivensis Döring}

PI.2, fig. 3

1966: Stereisporites (Sculptisporis) hauterivensis Döring, in Döring et al. (1966), p.77; pl.3, figs $1-3$.

Infraturma Apiculati (Bennie \& Kidston 1886) R. Potonié 1956

\section{Genus Trachysporites Nilsson 1958}

Trachysporites fuscus Nilsson

Pl.2, figs 4, 5; Pl.21, figs 1, 2, 7 (the holotype), fig. 2

1958: Trachysporites fuscus - Nilsson, p.38; pl.2, fig. $1\left(^{*}\right)$

1958: Trachysporites tuberosum - Nilsson, p.39; pl.2, fig. $2\left(^{*}\right)$

1958: Trachysporites sp.A - Nilsson, p.40; pl.2, fig. $6\left(^{*}\right)$

Trachysporites asper Nilsson

Pl.2, fig. 6; Pl.21, fig. 3 (the holotype)

1958: Trachysporites asper - Nilsson, p.39, pl.2, fig. $3\left(^{*}\right)$

Trachysporites sparsus (Bharadwaj \& Singh) Lund Pl.2, figs 7,8

1964a: Anemiidites spinosus - Mädler, p.180; pl.2, fig. 11.

1977: Conbaculatisporites spinosus (Mädler 1964) - Lund, p.56; pl.2, figs $11 a, b$. 
Genus Conbaculatisporites Klaus 1960

Conbaculatisporites mesozoicus Klaus

Pl.2, fig. 9

1960: Conbaculatisporites mesozoicus - Klaus, p.126; pl.29, fig. 15

Conbaculatisporites spinosus (Mädler) Lund

PI.2, fig. 10

1964a: Anemiidites spinosus - Mädler, p.180; pl.2, fig. 11.

1977: Conbaculatisporites spinosus (Mädler 1964) - Lund, p.56; pl.2, figs $11 \mathrm{a}, \mathrm{b}$.

Conbaculatisporites sp. 1

Pl.3, fig. 7

Description: Trilete spore with a subtriangular amb, straight to slightly convex sides and rounded angles. The trilete mark is distinct; the sutures extend for $4 / 5$ of the spore radius. The exine is $2-3$ microns thick, and sculptured with scattered 3-6 microns high baculae and spinae.

Equatorial diameter: about 61 microns (1 specimen). Remarks: Only one specimen was recorded, from sample Frh-16,c, one of the samples not counted. This specimen is therefore not mentioned in the rangechart. Because of secondary folding, the size could not be measured precisely.

Genus Baculatisporites Thomson \& Pflug 1953 emend. Krutzsch 1967

Baculatisporites wellmanii (Couper) Krutzsch

Pl.2, figs 11,12

1953: Osmundacidites wellmanii - Couper, p.20; pl.1, fig. 5 .

1959: Baculatisporites wellmanii (Couper 1953) - Krutzsch, p.142.

Baculatisporites comaumensis (Cookson) Potonié

Pl.3, fig. 6

1953: Triletes comaumensis - Cookson, p.470; pl.2, figs 27, 28.

1956: Baculatisporites (Triletes) comaumensis (Cookson 1953) - Potonié, p.33.

Baculatisporites oppressus (Leschik) Lund

Pl.3, fig. 3

1955: Cyclogranisporites oppressus - Leschik, p.17; pl.1, fig. 23.

1977: Baculatisporites oppressus (Leschik 1955) - Lund, p.57; pl.2, figs $15 \mathrm{a}, \mathrm{b}$.

\section{Cf. Baculatisporites sp.}

Pl.5, fig. 8

Description: Trilete spore with a subcircular amb. The trilete mark is distinct; the sutures extend for $4 / 5$ of the spore radius, and are bordered by a 3-4 microns wide labrum. The exine is $2-3$ microns thick, and sculptured with closely spaced verrucae and baculae, $1 / 2-2 \mathrm{mi}-$ crons wide and 1-2 microns high.

Equatorial diameter: about 66 microns (1 specimen). Remarks: Only one specimen was recorded from sample Fj-16,c. The exact dimensions could not be measured because of secondary folding.
Genus Apiculatisporis Potonié \& Kremp 1956

Apiculatisporis ovalis (Nilsson) Norris

Pl.3, figs 1, 2, 4, 5; Pl.21, figs 5, 6 (the holotype), fig. 8

1958: Acanthotriletes trigonus - Nilsson, p.41; pl.2, fig. $7\left({ }^{*}\right)$

1958: Acanthotriletes ovalis - Nilsson, p.40; pl.2, figs $8,9\left({ }^{*}\right)$

1965: Apiculatisporis ovalis (Nilsson 1958) - Norris, p.245; figs 2b, $18,22,23$

\section{Apiculatisporis parvispinosus (Leschik) Schulz}

1955: Apiculatisporites parvispinosus - Leschik, p.17; pl;2, figs 1-4. 1962: Apiculatisporis parvispinosus (Leschik 1955) - Schulz, p.312; pl.2, figs 16-19.

Remarks: This species has a mixed trilete-monolete mark.

\section{Genus Anapiculatisporites Potonié \& Kremp 1954}

Anapiculatisporites telephorus (Pautsch) Klaus

Pl.3, figs 8,9

1958: Sporites telephorus - Pautsch, p.323; pl.1, fig. 12.

1960: Anapiculatisporites telephorus (Pautsch) - Klaus, p.124; pl.29, fig. 17.

\section{Anapiculatisporites spiniger (Leschik) Reinhardt}

1955: Apiculatisporites spiniger - Leschik, p.18; pl.2, figs 6, 7. 1962: Anapiculatisporites spiniger (Leschik 1955) - Reinhardt, p. 707 , pl.1, fig. 8 .

Genus Taurocusporites Stover 1962

Taurocusporites verrucatus Schulz

Pl.3, figs 10,11

1967: Taurocusporites verrucatus - Schulz, p.566; pl.4, figs 14-16.

Genus Foraminisporis Krutzsch 1959

Foraminisporis jurassicus Schulz

Pl.3, fig. 12

1967: Foraminisporis jurassicus - Schulz, p.564; pl.4, figs 1-3; pl.23, fig. 3 .

\section{Genus Manumia Pocock 1970}

Manumia delcourtii Pocock comb. nov. et emend. Pl.4, fig. 5

1967: Trilites minutus (Bolchovitina 1961) - Mai, in Schulz 1967, p.562; pl.3, figs 7, 8 .

1970: Concavissimisporites delcourtii - Pocock, p.41; pl.7, fig. 9

1970: Concavissimisporites southeyensis - Pocock, p.41; pl.7, fig. 10

1985: Manumia variverrucata (Couper 1958) comb. nov. et emend. Hoelstad, p.123; pl.2, figs $15-17$

Emended diagnosis: Trilete spore with subtriangular $\mathrm{amb}$, straight to slightly convex or concave sides and rounded angles. The trilete mark is distinct, bordered by a labrum, 2-4 microns thick. The trilete mark is frequently gaping. The sutures extend for about $2 / 3$ of the spore radius. The exine is $1-2$ microns thick, sculptured on the proximal as well as the distal side, with scattered, irregularly shaped verrucae and granulae, 
0.5-3 microns wide, and 0.5-2 microns high. Some grains have a sculpture of verrucae of about similar size, others have a mixture of granulae and verrucae. The sculptural elements are irregularly spaced, 1-15 microns apart. The density of the elements varies from specimen to specimen, but they are not as sparse and widely scattered as on Manumia irregularis Pocock 1970.

Equatorial diameter (in the present study): 44 (49) 62 microns (10 specimens). The species Manumia delcourtii includes, however, specimens of a wide size-range, including some formerly referred to the species Trilites minutus (38-44 microns), and to Concavissimisporites delcourtii (72-75 microns).

Remarks: The genus Manumia Pocock 1970 comprises trilete spores with straight to slightly convex sides and a sculpturing of scattered verrucae or spines.

None of the three genera Concavissimisporites (Delcourt \& Sprumont 1955) Delcourt, Dettmann \& Hughes 1963, Concavisporites Pflug 1953 nor Trilites Cookson ex Couper 1953 seem suitable for the specimens referred to Manumia delcourtii in this study. According to Delcourt et al. (1963), the genus Concavissimisporites comprises trilete spores with concave to almost straight sides and a sculpturing of evenly distributed verrucae. The spores are generally relatively large (70-90 microns). The genus Concavisporites Pflug 1953 seems to be an extremely broadly defined genera. It has been used to encompass smooth as well as closely sculptured spores, generally concave, and with a wide span of size-ranges (Pflug 1953, Couper 1958, Pocock 1962). Specimens referred to the above mentioned two genera are generally recorded from Lower Cretaceous to Tertiary strata.

Hoelstad (1985) transferred the species Concavisporites variverrucatus Couper 1958 to the genus Manumia Pocock 1970, thus erecting the new combination Manumia variverrucata. This new combination seems inappropriate, as the species Concavisporites variverrucatus Couper 1958 comprises spores with distinctly concave sides and a sculpturing of relatively closely arranged, evenly spaced verrucae (see Couper 1958, Pl. 22, fig. 4 (the holotype), fig. 5). Although Couper (1958) states that the size and spacing of the verrucae on this species exhibit great variation, it is felt by the present author that it should be restricted to spores with the above mentioned main characteristics.

The genus Trilites Cookson ex Couper 1953 is too broadly defined to be useful. The species Trilites minutus (Bolchovitina 1961) Mai, in Schulz 1967, comprises relatively small specimens of the Manumia-type (diameter range 38-44 microns).

The three species Trilites minutus (Bolchovitina 1961) Mai, in Schulz 1967, Concavissimisporites southeyensis Pocock 1970 and Manumia variverrucata Hoelstad 1985 are treated as juniorsynonyms for Manumia delcourtii as these species fall within the variation of Manumia delcourtii according to the emended diagnosis.

\section{Cf. Manumia sp. 1}

Pl.4, fig. 6

Remarks: Only a single specimen of this type was found, in sample $\mathrm{Fj}-32, \mathrm{~s}$, one of the samples not counted. It is thus not shown in the range-charts. It has a distinct proximal kyrtome, like Deltoidospora toralis, but, in addition, is sculptured with irregularly spaced verrucae, like the specimens referred to Manumia.

\section{Genus Uvaesporites Döring 1965}

Uvaesporites argenteaeformis (Bolchovitina) Schulz $\mathrm{Pl} .4$, figs $1-4,7$

1953: Stenozonotriletes argenteaeformis - Bolchovitina, p.51; pl.7, fig. 9.

1962: Triletes reissingeri - Reinhardt, p.707; pl.2, figs 1, 2.

1967: Uvaesporites argenteaeformis (Bolchovitina 1953) - Schulz, p.560; pl.2, figs 10,11 ; pl.23, fig. 2 .

1977: Uvaesporites reissingeri (Reinhardt 1962) - Lund, p.60; pl.3, fig. 14

Genus Polypodiisporites Potonié \& Gelletich 1933 ex Potonié 1956

Remarks: This genus comprises spores with a mixed trilete-monolete aperture.

Polypodiisporites polymicroforatus (Orlowska-Zwolinska) Lund 1977

Pl.4, figs. 8, 9

1966: Foveosporites polymicroforatus - Orlowska-Zwolinska, p. 1011 ; pl.2, figs 15,16 ; pl.3, fig. $19-21$.

1967: Convolutispora microrugulata - Schulz, p.570; pl.6, figs 7-9.

1967: Convolutispora microfoveolata - Schulz, p.571; pl.6, figs 10, 11.

1977: Polypodiisporites polymicroforatus - Lund, p.32; pl.3, figs 6a, b.

Polypodiisporites polymicroforatus (Orlowska-Zwolinska) Lund 1977

Pl.4, figs 8, 9

1962: Verrucososporites ipsviciensis - de Jersey, p.7; pl.2, figs 8-10. 1965: Polypodiisporites ipsviciensis (de Jersey 1962) - Playford \& Dettmann, p.150; pl.15, figs 39-40.

Genus Leptolepidites Couper 1953 emend. Schulz 1967

Leptolepidites major Couper

Pl.4, figs 11, 12; Pl.5, figs 1, 2

1958: Leptolepidites major - Couper, p.141; pl.21, figs 7-8.

\section{Leptolepidites sp. 1}

P1.5, figs 3, 4

Description: Trilete spore with a subtriangular amb, straight to slightly convex sides and rounded angles. The trilete mark is rather indistinct; the sutures extend for about $4 / 5$ of the spore radius. Proximally the exine is 
laevigate. Distally and equatorially the exine is sculptured with closely spaced verrucae, 3-6 microns wide and 1-3 microns high.

Equatorial diameter: 20 microns (1 specimen).

Remarks: Only one specimen was recorded, from sample St-16,w.

\section{Leptolepidites $\mathrm{sp} .2$}

Pl.5, figs 5, 6

Description: Monolete spore with an elliptical equatorial outline. The monolete mark extends along the entire spore-length. The exine is laevigate on the proximal surface, while on the distal and equatorial surface it is sculptured with closely spaced verrucae of variable size, between 1 and 10 microns in diameter, largest in the equatorial region, and 2-3 microns high.

Dimensions: length: 26 microns; width: 21 microns (1 specimen).

Remarks: Only one specimen was recorded, in sample Frh-22,s. This specimen is referred to the Anteturma Apiculati, in spite of the monolete mark, because of its assumed relation with the genus Leptolepidites.

\section{Infraturma Murornati Potonié \& Kremp 1954}

Genus Lycopodiumsporites Thiergart 1938 ex. Delcourt \& Sprumont 1955

\author{
Lycopodiumsporites semimuris Danzé-Corsin \& La- \\ veine \\ Pl.5, figs 9, 10 \\ 1963: Lycopodiumsporites semimuris - Danzé-Corsin \& Laveine, \\ p.79; pl.6, figs. 15a, b, 16a, b, 17a, b, c.
}

Lycopodiumsporites austroclavatidites (Cookson) Potonié

Pl.5, figs 12,13

1953: Lycopodium austroclavatidites - Cookson, p.269; pl.2, fig. 35.

1956: Lycopodiumsporites (al. Lycopodium) austroclavatidites (Cookson 1953) - Potonié, p.46.

1963: Retitriletes austroclavatidites (Cookson 1953) - Döring, Krutzsch, Mai \& Schulz, in Krutzsch (1963, Lief.II), p.16.

Lycopodiumsporites clavatoides (Couper) pro parte emend. Tralau

1958: Lycopodiumsporites clavatoides - Couper, p.132; pl.15, figs 10-13.

1963: Retitriletes clavatoides (Couper 1958) - Döring, Krutzsch, Mai \& Schulz, in Krutzsch (1963, lief.II), p.16.

1968: Lycopodiumsporites clavatoides (Couper 1958) pro parte emend. - Tralau, p.49; pl.1, figs 3-5.

Lycopodiumsporites gracilis Nilsson

Pl.5, figs 11,14

1958: Lycopodiumsporites gracilis - Nilsson, p.46; pl.2, figs 12, 13.
Lycopodiumsporites sp.1.

Pl.6, figs 1-3

Description: Trilete spore with subtriangular to subcircular amb, and slightly convex sides. The trilete mark is distinct, bordered by a thin labrum, about 1 micron wide. The sutures extend for the entire radius of the spore, exclusive of the reticulum. On the proximal side of the spore the exine is laevigate, while the exine equatorially and distally is sculptured with a distinct reticulum. The muri are about 1 micron wide and about 5 microns high. The luminae are 7-12 microns in diameter. The meshes of the reticulum overlap and interlock each other.

Equatorial diameter: about 40 microns (1 specimen). Remarks: Only one specimen was recorded, from sample Fj-16,c. The recorded specimen differs from the other species of Lycopodiumsporites in having a reticulum built up of interlocking meshes. The species Retitriletes concavus erected by Schulz (1966) is also characterized by having interlocking meshes, but it is further characterized by concave sides, and muri only 1-2 microns high. Furthermore the reticulum of the species recorded in the present study seems more regular than the specimens illustrated by Schulz (1966, textfig. 1; pl.2, figs 7-9).

\section{Genus Semiretisporis Reinhardt 1962}

Semiretisporis gothae Reinhardt

Pl.6, fig. 4

1962: Semiretisporis gothae - Reinhardt, p.709; pl.2, figs 5, 6 .

\section{Genus Costatisulcites Scheuring 1978}

\section{Costatisulcites $\mathrm{cf}$. ovatus Scheuring \\ Pl.6, fig. 5}

Remarks: Only one, very corroded specimen was recorded, from sample Fj-4,c. It is therefore not possible to compare it in detail with the species Costatisulcites ovatus erected by Scheuring (1978). The recorded specimen may be reworked.

\section{Genus Lycopodiacidites Couper 1953}

\section{Lycopodiacidites rugulatus (Couper) Schulz}

1958: Perotriletes rugulatus - Couper, p.147; pl.25, figs 7, 8.

1967: Lycopodiacidites rugulatus (Couper 1958) - Schulz, p.573; pl.7, figs 15,16 .

\section{Genus Tigrisporites Klaus 1960}

Tigrisporites scurrandus Norris

Pl.6, figs $6,8,11$

1967: Tigrisporites scurrandus - Norris, p.91; pl.11, figs 3-7.

Remarks: The specimens referred to this species by Norris (1967) were recorded from a Lower Cretaceous 
sequence from Central Alberta. The species Tigrisporites halleinis Klaus 1960, known from the European Upper Triassic, shows the same main characteristics as Tigrisporites scurrancus but differs in having more closely spaced, and differently arranged, distal rugulae, a laevigate proximal surface, and a larger size (40-68 microns contra 25-39 microns in spore-diameter for Tigrisporites scurrandus).

\section{Genus Staplinisporites Pocock 1962}

\section{Staplinisporites telatus (Balme) Döring}

1957: Microreticulatisporites telatus - Balme, p.25; pl.4, figs 52, 53. 1965: Staplinisporites telatus (Balme 1957) - Döring, p.45; pl.15, figs 6-8.

\section{Genus Ischyosporites Balme 1957}

The two genera Ischyosporites Balme 1957 and Klukisporites Couper 1958 have been treated in the present study as two separate genera, in accordance with, among others, Dettmann (1963) and Filatoff (1975).

According to the rules of Botanical Nomenclature the genus Klukisporites should be considered as a junior synonym of Ischyosporites, as followed by several authors (e.g. Schulz 1967, Tralau 1968, Guy 1971, Van Konijnenburg-Van Cittert 1981, Guy Ohlson 1986). Two clearly distinguishable groups of specimens of the Ischyosporites/Klukisporites type were, however, recorded in the present study: One group of spores showed a regular foveo-reticulate exine with a uniform thickness, without valvae. These specimens have been recorded as Klukisporites. The other group consists of spores showing a more irregular foveo-reticulate sculpture, where the muri are raised and undulating, constituting a valvate sculpture. These specimens have been referred to the genus Ischyosporites.

To solve the problems concerning these two genera, the genus Klukisporites should be emended and a new type species should be chosen. The present type species, Klukisporites variegatus has a valvate sculpture, and generally shows the main characteristics of the genus Ischyosporites. It is therefore generally treated as a junior synonym of Ischyosporites variegatus and this has been followed here.

\section{Ischyosporites variegatus (Couper) Schulz}

\section{Pl.6, fig. 7}

1958: Klukisporites variegatus - Couper, p.137; pl.19, figs 6,7 .

1967: Ischyosporites variegatus (Couper 1958) - Schulz, p.569; pl.5, figs $9,10$.

\section{Genus Klukisporites Couper 1958}

\section{Klukisporites lacunus Filatoff}

Pl.7, fig. 1

1975: Klukisporites lacunus -Filatoff, p.69; pl.15, fig. 9, pl.16, figs 1, 2.
Subturma Zonotriletes Waltz 1935

Infraturma Auriculati (Schopf 1938) Dettmann 1963

Genus Triancoraesporites Schulz 1962

Triancoraesporites ancorae (Reinhardt) Schulz

Pl.7, figs 4, 5

1962: Waltzispora ancorae - Reinhardt, p.705, pl.1, fig. 14.

1967: Triancoraesporites ancorae (Reinhardt 1962) - Schulz, p.580; pl.11, figs 4,5 .

\section{Triancoraesporites reticulatus Schulz}

Pl.7, fig. 6

1962: Triancoraesporites reticulatus - Schulz, p.311; pl.2, figs 14, 15

Genus Platyptera Naumova 1934 ex. Naumova 1938

Platyptera trilingua (Horst) Schulz

1943: Triletes (Zonale) trilinguis - Horst, figs 55, 56.

1967: Platyptera trilingua (Horst 1943) - Schulz, p.579; pl.11, figs 1, 2.

Remarks: The recorded specimens are probably reworked. Platyptera trilingua is generally known from Carboniferous strata (Smith \& Butterworth 1967).

\section{Infraturma Tricrassati Dettmann 1963}

\section{Genus Gleicheniidites Ross 1949}

Gleicheniidites senonicus Ross

Pl.7, figs 7, 8

1949: Gleicheniidites senonicus - Ross, p.31; pl.1, figs 3, 4.

Remarks: The frequent occurrence of this species in the cuttings samples from the Frederikshavn-2 borehole (especially in sample Frh-20,s) is probably due to caving. Specimens referred to Gleicheniidites senonicus were, however, recorded sporadically from some of the core samples in the present study $(\mathrm{Fj}-15, \mathrm{c}$, Frh $12, \mathrm{c}$ and Frh-22,c), referred to Early and/or Middle Jurassic.

\section{Gleicheniidites conspiciendus (Bolchovitina) Krutzsch}

1953: Gleichenia conspicienda - Bolchovitina, p.45; pl.8, figs 4, 5 .

1959: Gleicheniidites (Peregrinisporis) conspiciendus (Bolchovitina 1953) - Krutzsch, p.114.

Genus Skarbysporites Van Erve 1977

\section{Skarbysporites crassexinus (Nilsson) Lund}

1958: Concavisporites crassexinius - Nilsson, p.35; pl.1, fig. 11.

1967: Gleicheniidites umbonatus (Bolchovitina 1953) - Schulz, p.556, pl.1, figs 3,4 .

1977: Deltoidospora crassexina (Nilsson 1958) - Lund, p.51; pl.1, figs. 4a, b; pl.12, figs 8 a, b.

1988: Skarbysporites crassexinus (Nilsson 1958) - Lund \& Ecke, p.354; pl. 3, figs 7, 8 .

Remarks: See photo in Dybkjær (1988, pl.1, fig. 3) (Deltoidospora crassexina (Nilsson 1958) Lund 1977). 
Densosporites fissus (Reinhardt) Schulz

Pl.8, fig. 8

1964: Densoisporites fissus - Reinhardt, p.54; pl.2, figs 1-3.

1967: Densosporites fissus (Reinhardt 1964) - Schulz, p.582; pl.12, figs 5,6 .

Remarks: Some of the specimens found could be reworked.

\section{Zebrasporites laevigatus (Schulz) Schulz}

Pl.7, fig. 12

1962: Thuringiasporites laevigatus - Schulz, p.310; pl.1, fig. 6 .

1967: Zebrasporites laevigatus (Schulz 1962) - Schulz, p.589; pl.15, figs 10,11 .

\section{Genus Perinosporites Schulz 1962}

\section{Perinosporites thuringiacus Schulz}

$\mathrm{Pl} .8$, figs 2, 3

1962: Perinosporites thuringiacus - Schulz, p.309; pl.1, figs 1, 2.

Genus Camarozonosporites Pant 1954 ex Potonié 1956

\section{Camarozonosporites laevigatus Schulz}

Pl.8, fig. 1

1967: Camarozonosporites (Camarozonosporites) laevigatus Schulz, p.572; pl.7, figs 7-9, pl.25, fig. 3.

\section{Camarozonosporites rudis (Leschik) Klaus}

Pl.8, fig. 4

1955: Verrucosisporites rudis - Leschik, p.15; pl.1, fig. 15

1960: Camarozonosporites rudis (Leschik 1955) - Klaus, p.136; pl.29, fig. 16.

1963: Camarozonosporites (Camarozonosporites) rudis (Leschik 1955) Klaus 1960 - Krutzsch 1963, p.20.

Remarks: This species differs from Camarozonosporites laevigatus in having a murornate exine, resulting in a striated appearance.

\section{Infraturma Cingulati Potonié \& Klaus 1954}

Genus Lycospora Schopf, Wilson \& Bentall 1944 emend. Potonié \& Kremp 1954

\section{Lycospora salebrosacea (Maljavkina) Schulz Pl.8, figs 5-7}

1949: Volucellina salebrosacea - Maljavkina, p.65; pl.13, fig. 14

1958: Aequitriradites salebrosaceus (Maljavkina 1949) - Nilsson, p. 47 ; pl.3, fig. 8 .

1967: Lycospora salebrosacea (Maljavkina 1949) - Schulz, p.584; pl.13, figs $8-10$.

Remarks: This species is generally regarded as a Carboniferous form (Smith \& Butterworth 1967). The recorded specimens are probably reworked, although most of them are well preserved and do not show any signs of corrosion or darkening.

Genus Densosporites Berry 1937 emend. Potonié \& Kremp 1954
Densosporites cavernatus Orlowska-Zwolinska
Pl.8, figs 9,10
1966: Densosporites cavernatus - Orlowska-Zwolinska, p.1013; pl.6,
$\quad$ figs $26-30$.
1967: Densosporites foveocingulatus - Schulz, p.582; pl.12, figs 7, 8 .

Cf. Densosporites spp.

Pl.8, figs 11-13

Remarks: This group comprises several different types of specimens, some of which are shown in the photoplates. They are all presumed to be reworked and are generally in a very bad state of preservation. In the range-charts they compose the main part of the category "other Cingulati".

\section{Genus Crassispora Bharadwaj 1957}

\section{Cf. Crassispora sp. \\ Pl.9, fig. 1}

Description: Trilete spore with subtriangular to subcircular amb, convex sides and rounded angles. The slightly undulating trilete mark is distinct, bordered by a thick labrum. The delimitation between the body and the cingulum is indistinct. The cingulum is about 8 microns wide. The exine is about 2 microns thick, and sculptured with irregularly spaced granulae and coni, 0.5-1.5 microns wide, and 0.5-1 microns high.

Equatorial diameter: about 50 microns (1 specimen). Remarks: Only one specimen of this type was recorded. It is in a rather poor state of preservation, and is presumed to be reworked, probably from the Carboniferous (see Smith \& Butterworth 1967). The recorded specimen differs from the original diagnosis of Crassispora in having a distinct trilete mark with labrum.

\section{Genus Cingutriletes Pierce 1961}

\section{Cingutriletes infrapunctus (Schulz) Morbey} Pl.9, fig. 3

1970: Stereisporites (Cingutriletes) infrapunctus - Schulz, p.688; pl.130, figs 22, 23; pl.131, fig. 1 .

1975: Cingutriletes infrapunctus (Schulz 1970) - Morbey, pl.9, fig. 4.

Genus Cingulizonates Dybova \& Jachowicz 1957

Pl.9, fig. 2

1962: Aequitriradites? rhaeticus - Reinhardt, p.709; pl.2, fig. 3.

1967: Cingulizonates rhaeticus (Reinhardt 1962) - Schulz, p.584; pl.13, figs 6, 7 .
Cingulizonates rhaeticus (Reinhardt) Schulz 
Genus Striatella Mädler 1964a emend. Filatoff \& Price 1988

Remarks: Filatoff \& Price (1988) discussed the problem of the numerous types of trilete, muronate spores generally ascribed to either Contignisporites Dettmann 1963 or Duplexisporites Deák 1962. They subdivided this group into the genera Contignisporites Dettmann 1963, Striatella Mädler 1964a emend. Filatoff \& Price 1988, and Crassitudisporites Hiltmann 1967. The two first mentioned genera differ from the last mentioned in having a single tangential murus on the outer edge of each proximal interradial area. Furthermore Contignisporites is distinguishable from Striatella in lacking a "disto-equatorial" murus.

The two species recorded occur together in the range-chart, as Striatella spp.

Striatella seebergensis Mädler

Pl.10, fig. 5

1964a: Striatella seebergensis - Mädler, p.189; pl.3, fig. 8 .

Striatella jurassica Mädler

Pl.10, figs 3,4

1964a: Striatella jurassica - Mädler, p.192; pl.3, fig. 12.

\section{Genus Limbosporites Nilsson 1958}

\section{Limbosporites lundbladii Nilsson}

$\mathrm{Pl} .9$, figs 4,5

1958: Limbosporites lundbladii-Nilsson, p.47; pl.3, fig. 7.

\section{Genus Heliosporites Schulz 1962}

Heliosporites altmarkensis Schulz

$\mathrm{Pl} .9$, fig. 8

1962: Heliosporites altmarkensis - Schulz, p.311; pl.1, fig. 9; pl.2, figs 10,11 .

Genus Murospora Somers 1952

Murospora florida (Balme) Pocock

Pl.9, fig. 7

1957: Cingulatisporites floridus - Balme, p.26; pl.5, figs 60-61.

1961: Murospora florida (Balme 1957) - Pocock, p.1233, text-figs 1-7.

Remarks: Only one specimen was recorded, from sample Frh-19,c. Schulz (1967) has recorded specimens referred to Murospora florida from Pliensbachian and Toarcian strata in East Germany.

\section{Cf. Murospora sp.}

Pl.9, fig. 9

Description: Trilete, cingulate spore with subtriangular amb, concave sides and rounded angles. The trilete mark is distinct, bordered by a labrum about 3 microns wide. The sutures extend for about $2 / 3$ of the spore radius. The cingulum is about 6 microns wide, with a finely undulating edge. The exine is sculptured with closely spaced granulae or small verrucae, 1-2 microns wide, and 1-2 microns high.

Equatorial diameter: 47 microns (1 specimen).

Remarks: Only one specimen was recorded, from sample $\mathrm{Fj}-23$,s. This specimen is probably reworked. It is most similar to the specimen presented by Guy-Ohlson, Lindqvist \& Norling (1987, fig. 5,B), which was referred to Murospora intorta (Waltz in Luber \& Waltz 1938) Playford 1962, and also presumed to be caved from Carboniferous strata.

\section{Genus Iraquispora Singh 1964}

Iraquispora laevigata (Mädler) Lund

P1.9, fig. 6

1964a: Kyrtomisporites laevigatus - Mädler, p.188; pl.3, fig. 4.

1977: Iraquispora laevigata (Mädler 1964) - Lund, p.60; pl.3, fig. 12.

Genus Polycingulatisporites Simoncsics \& Kedves 1961 emend. Playford \& Dettmann 1965

Polycingulatisporites triangularis (Bolchovitina) Playford \& Dettmann

Pl.10, figs 7,8

1956: Chomotriletes triangularis - Bolchovitina, p.61; pl.7, fig. 98a, ?figs $98 \mathrm{~b}, 98 \mathrm{c}$

1965: Polycingulatisporites triangularis (Bolchovitina 1956) - Playford \& Dettmann, p.144.

Remarks: Only one specimen was recorded, from sample St-5,c.

Polycingulatisporites liassicus Schulz

Pl.10, figs 6, 9

1967: Polycingulatisporites liassicus - Schulz, p.587; pl.14, figs 7-9.

Turma Monoletes Ibrahim 1933

Subturma Azonomonoletes Luber 1955

Genus Laevigatosporites Ibrahim 1933

Laevigatosporites mesozoicus Schulz

1967: Laevigatosporites mesozoicus - Schulz, p.590; pl.16, figs 1, 2.

\section{Genus Marattisporites Couper 1958}

Marattisporites scabratus Couper

PI.10, fig. 10

1958: Marattisporites scabratus - Couper, p.133; pl.15, figs 20-23.

\section{Cf. Marattisporites sp.1}

Pl.10, fig. 11

Description: Monolete spore, with a broadly elliptical amb. The monolete mark is distinct, and extends for about $1 / 2$ of the spore length. The exine is about 1 micron thick, and sculptured with closely spaced gran- 
ulae, 1 micron or less in diameter, and about $1 / 2$ micron high.

Dimensions: length: 23 microns; width: 19 microns (1 specimen).

Remarks: Only one specimen was recorded, from sample St-6,c.

\section{Subturma Zonomonoletes}

Genus Aratrisporites Leschik 1955 emend. Playford \& Dettmann 1965

Aratrisporites minimus Schulz

Pl.11, fig. 1

1967: Aratrisporites minimus - Schulz, p.592; pl.16, figs 7-9.

Aratrisporites fimbriatus (Klaus) Playford \& Dettmann Pl.11, fig. 2

1960: Saturnisporites fimbriatus - Klaus, p.142; pl.32, figs 32, 33

1965: Aratrisporites fimbriatus (Klaus 1960) - Playford \& Dettmann, p. 152.

Anteturma Pollenites Potonié 1931

Turma Saccites Erdtman 1947

Subturma Disaccites Cookson 1947

\section{Genus Vitreisporites Leschik 1955}

Vitreisporites pallidus (Reissinger) Nilsson

Pl.11, fig. 3

1950: Pityopollenites pallidus - Reissinger, p.109; pl.15, figs 1-5.

1958: Caytonipollenites pallidus - Couper, p.150; pl.26, figs 7, 8

1958: Vitreisporites pallidus (Reissinger 1950) - Nilsson, p.78; pl.7, figs $12-14$.

Vitreisporites bjuvensis Nilsson

Pl.11, fig. 4; Pl.22, fig. 1,2 (the holotype)

1958: Vitreisporites bjuvensis - Nilsson, p.79; pl.7, fig. 11(*).

Remarks: This species differs from Vitreisporites palli$d u s$ in having a larger size (27-36 microns contra 25-30 microns for Vitreisporites pallidus according to Nilsson (1958)), and slightly pointed sacci.

Genus Pinuspollenites Raatz 1937 ex. Potonié 1958

\section{Pinuspollenites minimus (Couper) Kemp}

Pl.11, figs 5, 7

1958: Abietineaepollenites minimus - Couper, p.153; pl.28, figs 14, 15

1958: Taedaepollenites scaurus - Nilsson, p.87; pl.7, figs $16,17\left({ }^{*}\right)$.

1967: Pityosporites scaurus (Nilsson 1958) - Schulz, p.595; pl. 17, figs 12,13 .

1970: Pinuspollenites minimus (Couper 1958) - Kemp, p.116; pl. 24, figs $1-6$.

\section{Pinuspollenites pinoides (Nilsson) Lund}

1958: Sulcatisporites pinoides - Nilsson, p.86; pl.8, figs 6, 7 .

1977: Pinuspollenites pinoides (Nilsson 1958) - Lund, p.76; pl. 9, fig. 7 .
Genus Protopinus Bolkhovitina 1956

Protopinus scanicus Nilsson

Pl.11, fig. 6

1958: Protopinus scanicus - Nilsson, p.84; pl.8, figs 4, 5 .

Genus Alisporites Daugherty 1941

Alisporites robustus Nilsson

Pl.11, fig. 8; P1.22, figs 3, 4 (the holotype)

1958: Alisporites robustus - Nilsson, p.82; pl.8, figs 2, $3\left(^{*}\right)$.

Alisporites radialis (Leschik) Lund

1955: Cunaetisporites radialis - Leschik, p.66; pl.10, fig. 6

1977: Alisporites radialis (Leschik 1955) - Lund, p.75; pl.9, figs 3, 4 .

\section{Alisporites thomasii (Couper) Nilsson}

1958: Pteruchipollenites thomasii-Couper, p.150; pl.26, figs 10-12. 1958: Alisporites thomasii (Couper 1958) - Nilsson, p.83; pl.8, fig. 1.

\section{Alisporites grandis (Cookson) Dettmann}

1953: Disaccites grandis - Cookson, p.471; pl.2, fig. 41.

1963: Alisporites grandis (Cookson 1953) - Dettmann, p.102; pl.25, figs $1-4$.

\section{Alisporites microsaccus (Couper) Pocock}

1958: Pteruchipollenites microsaccus - Couper, p.151; pl.26, fig. 13 1962: Alisporites cf. A. microsaccus (Couper 1958) - Pocock, p.61; pl.9, figs 138,139

Genus Ovalipollis Krutzsch 1955

Ovalipollis ovalis Krutzsch

PI.11, fig. 10

1955: Ovalipollis ovalis - Krutzsch, p.70; pl.1, fig. 2.

\section{Genus Quadraeculina Maljavkina 1949}

Quadraeculina anellaeformis Maljavkina Pl.12, fig. 1

1949: Quadraeculina anellaeformis - Maljavkina, p.110; pl.39, fig. 3 1958: Chasmatosporites radiatus - Nilsson, p.58; pl.4, fig. $9\left(^{*}\right)$

Genus Schismatosporites Nilsson 1958

Schismatosporites ovalis Nilsson

Pl.22, fig. 5 (the holotype)

1958: Schismatosporites ovalis - Nilsson, p.76; pl.10, fig. $2\left(^{*}\right)$.

\section{Genus Umbrososaccus Mädler 1964}

Umbrososaccus keuperianus Mädler

Pl.12, fig. 2

1964b: Umbrososaccus keuperianus - Mädler, p.118; pl.11, figs 5, 8 .

Genus Taeniaesporites Leschik 1955

Taeniaesporites sp.

Pl.12, fig. 3 
Description: Bisaccate pollen grain with four parallel taeniae; two large and distinct, placed proximally; and two narrow and indistinct, placed equatorially, one at each side. The total outline is elliptical. The corpus is circular in polar view. The sacci are almost hemispherical, attached to the corpus equatorially. The sacciroots are indistinct. The taeniae runs from one saccus to the other. The two distinct ones are 5-6 microns wide, with a 5 microns wide space between them, while there is about 3 microns between the distinct ones and the narrow ones.

Dimensions: corpus-length: 32 microns; width: $36 \mathrm{mi}-$ crons. Sacci length: 31 microns; width: 22 microns. Total length: 31 microns; width: 70 microns $(1$ specimen).

Remarks: Only one specimen was recorded, from sample $\mathrm{Fj}-3$,c. This specimen is in a very bad state of preservation, which made determination at the species level impossible. This specimen may be reworked.

Turma Aletes Ibrahim 1933

Subturma Azonaletes (Luber 1935) Potonié \& Kremp 1954

\section{Genus Araucariacites Cookson 1947 ex. Couper 1953}

\section{Araucariacites australis Cookson}

1947: Granulonapites (Araucariacites) australis - Cookson, p.130; pl.13, figs $1-4$.

\section{Genus Perinopollenites Couper 1958}

Remarks: The endexine and ektexine are totally separated. The ektexine forms a velum, that is easily torn and is thus often missing (see pl. 12, figs 4-9). The "naked" inner-bodies could be taken for other palynomorph-genera, the inner-body of Perinopollenites cf. elatoides could in particular be confused with specimens of Polypodiisporites.

\section{Perinopollenites elatoides Couper}

Pl.12, figs 4-6

1958: Perinopollenites elatoides - Couper, p.152; pl.27, figs 9-11.

\section{Perinopollenites cf. elatoides Couper}

Pl.12, figs 7-9

Remarks: These specimens differ from Perinopollenites elatoides Couper 1958 in having a small, thick-walled, dark inner-body, and a smaller total size, 40-45 microns.

Genus Cupressacites (Bolkhovitina 1956) Krutzsch 1971

\section{Cupressacites sp.}

Description: Alete pollen grains with a spherical outline, though normally secondarily folded. The exine is very thin (about 0.5 microns), transparent, and laevigate.

Dimensions: 30 (39) 48 microns (3 specimens).

Remarks: See photo in Dybkjær (1988, pl.9, fig. 3).

\section{Genus Cerebropollenites Nilsson 1958}

Cerebropollenites macroverrucosus (Thiergart) Schulz PI.13, fig. 1

1949: Pollenites macroverrucosus - Thiergart, p.17; pl.2, fig. 19.

1958: Tsugaepollenites mesozoicus - Couper, p.155; pl.3, figs 8-10.

1958: Cerebropollenites mesozoicus (Couper 1958) - Nilsson, p.72; pl.6, figs $10-12$.

1967: Cerebropollenites macroverrucosus (Thiergart 1949) - Schulz, p.603; pl.21, figs 4-6.

Remarks: According to Schulz (1967) the two species Cerebropollenites macroverrucosus and Cerebropollenites thiergartii differ in the size of the verrucae. Furthermore the verrucae on the former are hollow and often elongated, while those on the latter are compact and circular.

The specimens referred to Cerebropollenites macroverrucosus by Orbell (1973, pl. 2, figs 5-7) should not be referred to this species. According to Morbey (1975) they should be referred to Tsugapollenites? pseudomassulae (Mädler 1964a) Morbey 1975.

\section{Cerebropollenites thiergartii Schulz}

Pl.13, figs 2-6

1967: Cerebropollenites thiergariii-Schulz, p.603; pl.21, figs 7, 8 .

Remarks: Some of the specimens referred to this species in this study seem to have a regular sulcus (pl.13, figs 4-6), while others only have an area with thin exine (pl.13, figs 2 and 3). Nilsson (1958), who erected the genus Cerebropollenites, described it as inaperturate, while Schulz (1967), who erected the species Cerebropollenites thiergartii, described the genus as monocolpate. The variation seen in this study of Cerebropollenites thiergartii covers both possibilities, while no $\mathrm{Ce}$ rebropollenites macroverrucosus was recorded with a sulcus-like aperture.

\section{Genus Spheripollenites Couper 1958}

Remarks: Specimens of this genus often occur in clusters, as mentioned for Spheripollenites subgranulatus by Schulz (1967), and for the genus by Batten (1978). In the present study this tendency is especially pronounced for Spheripollenites psilatus in samples St-15,w and $\mathrm{Fj}-15$, $\mathrm{C}$ where this species occur in large numbers.

The present author doubts whether these specimens are pollen grains or algae, as they show no features that definitively confirm any of these relationships. Batten (1978) proposed an algal origin, especially for the clustered specimens, while Wille (1982) suggested that $I n$ aperturopollenites orbiculatus, a junior synonym to Spheripollenites psilatus, represent a conifer related to 
the Cheirolepidiaceae, the same family which produced the Corollina type of pollen. An investigation of the geochemical composition of the exine may solve the problem.

\section{Spheripollenites psilatus Couper}

Pl.13, fig. 7

1958: Spheripollenites psilatus - Couper, p.159; pl.31, figs 4-8.

1958: Inaperturopollenites orbiculatus - Nilsson, p.68; pl.6, figs $2-4$.

\section{Spheripollenites subgranulatus Couper}

1958: Spheripollenites subgranulatus - Couper, p.158; pl.31, figs 9-11.

\section{Genus Exesipollenites Balme 1957}

Exesipollenites tumulus Balme

Pl.13, fig. 8

1957: Exesipollenites tumulus - Balme, p.39; pl.11, figs 123-125.

Subturma Zonaletes Luber 1935 emend. Potonié 1958

\section{Genus Callialasporites Dev 1961}

\section{Callialasporites trilobatus (Balme) Dev}

Pl.14, fig. 1

1957: Zonalapollenites trilobatus - Balme, p.33; pl.8, figs 91, 92

1961: Callialasporites trilobatus (Balme 1957) - Dev, p.48; pl.4, figs $28,29$.

Remarks: Only one specimen was recorded, from sample Frh-13,s. This specimen could be caved, but the species Callialasporites trilobatus is known from the Lower Jurassic (Filatoff 1975).

\section{Callialasporites dampieri (Balme) Dev}

\section{Pl.14, fig. 2}

1957: Zonalapollenites dampieri - Balme, p.32; pl.8, figs 88-90.

1961: Callialasporites dampieri (Balme 1957) - Dev, p.48; pl.4, figs $26,27$.

1963: Tsugapollenites dampieri (Balme 1957) - Dettmann, p.100; pl.24, figs 1-5.

Remarks: Schulz (1967) mentioned that specimens referred to Callialasporites dampieri sometimes show the indication of a trilete mark. Some of the specimens recorded in the present study, show a distinct triletemark.

Turma Plicates (Naumova 1939) Potonié 1960 Subturma Monocolpates Iversen \& Troels-Smith 1950

Genus Chasmatosporites Nilsson 1958 emend. Pocock \& Jansonius 1969

Remarks: Nilsson (1958) erected no less than 11 species, two new combinations, and one Chasmatosporites sp.A, referred to this genus. Morbey (1975) combined 9 of these species into one, Chasmatosporites magno- lioides (Erdtman 1948) Nilsson 1958, while Chasmatosporites apertus was kept as a separate species. Chasmatosporites crassus and Chasmatosporites sp.A Nilsson 1958 were not' mentioned by Morbey, while Chasmatosporites radiatus Nilsson 1958, was treated as a junior synonym of Quadraeculina anellaeformis Maljavkina 1949.

The stratigraphical distribution, according to earlier investigations, of 15 species of Chasmatosporites in Sweden has recently been presented by Guy-Ohlson (1988). Six of these species, all recorded from the Vilhelmsfält-1 borehole, Scania, were described, and the possible stratigraphical potential of these was proposed.

Nilssons (1958) type-material was investigated in connection with the present study. Unfortunately the slides with several of the type-species of, among others, Chasmatosporites major and Chasmatosporites hians have been lost.

The four species recorded in the present study could be distinguished relatively easily. Several of the species erected by Nilsson (1958) are here treated as junior synonyms. They are described in detail below to clarify the delimitation of the recorded species.

\section{Chasmatosporites apertus (Rogalska) Nilsson}

Pl.14, fig. 3

1954: Pollenites apertus - Rogalska, p.45; pl.12, figs 13-15.

1958: Chasmatosporites apertus (Rogalska 1954) - Nilsson, p.56; pl.4, figs 5, 6 .

1958: Chasmatosporites crassus - Nilsson, p.57; pl.5, fig. 3

1958: Chasmatosporites flavus - Nilsson, p.57; pl.5, fig. 4.

Description: The equatorial outline is circular, or nearly circular, with an irregular edge. The colpus is elliptical to circular, and wide open. The colpus-length is about $2 / 3$ of the total diameter. The exine is thick ( $2-4$ microns); the intrastructure of the exine is diffuse to fine intrareticulate. Dimensions: spore-diameter: $29-46$ microns (17 specimens).

Chasmatosporites elegans Nilsson Pl.14, fig. 6; Pl.22, fig. 6 (the holotype)

1958: Chasmatosporites elegans - Nilsson, p.58; pl.4, figs $11,12\left(^{*}\right)$ 1958: Chasmatosporites minor - Nilsson, p.58; pl.4, fig. 10.

Description: The equatorial outline is elliptical, with a smooth edge. The colpus is elliptical to triangular, more or less wide open. The exine is $0.5-1$ microns thick, tectate with a regular micro-intrareticulum.

Dimensions: length: $35-50$ microns; width: $30-46 \mathrm{mi}-$ crons (10 specimens).

\section{Chasmatosporites hians Nilsson}

Pl.14, figs 4, 5

1958: Chasmatosporites hians - Nilsson, p.55; pl.4, figs 3, 4.

Description: The equatorial outline is circular to ellipti- 
cal, with a smooth to slightly irregular edge. The colpus is circular to elliptical, and wide open. The colpuslength is about $2 / 3$ of the total length. The exine is $1-2$ microns, with a distinct, irregular (vermiculate) microintrareticulum, with luminae about 1 micron in diameter and relatively narrow muri.

Dimensions: length: 44-76 microns; width: 30-51 microns (27 specimens).

\section{Chasmatosporites major Nilsson}

\section{Pl.14, fig. 7}

1958: Chasmatosporites major - Nilsson, p.54; pl.3, figs 10-15.

Description: The equatorial outline is elliptical, with a smooth edge. The colpus is elliptical. In some specimens the colpus has probably collapsed, resulting in a "closed" appearance, giving the grain a "spindleshaped" outline. The colpus almost reaches the total length of the grain. The exine is $1-3$ microns thick, and has a regular micro-intrareticulum with luminae of 0.5-1 microns, and relatively thick muri.

Dimensions: length: 61-88 microns; width: 49-55 microns (11 specimens).

Genus Ricciisporites Lundblad 1954 emend. Lundblad 1959

Ricciisporites tuberculatus Lundblad

Pl.14, figs 8,9

1954: Ricciisporites tuberculatus - Lundblad, p.401; pl.4, figs 8, 9.

Remarks: This species normally occurs in tetrads. In the present study fragments are very common in some samples, especially in sample St-1,c. If a fragment constituted a quarter of a tetrad, or more, it was recorded as a "fragment". In the range-charts this species is therefore to be found both as Ricciisporites tuberculatus (tetrads), and as Ricciisporites tuberculatus (fragments).

Genus Monosulcites Cookson 1947 ex. Couper 1953

\section{Monosulcites minimus Cookson}

Pl.15, fig. 1

1947: Monosulcites minimus - Cookson, p.135; pl.15, figs 47-50.

\section{Monosulcites punctatus Orlowska-Zwolinska}

1958: Entylissa reticulata - Nilsson, p.62; pl.5, fig. $14\left({ }^{*}\right)$

1966: Monosulcites punctatus - Orlowska-Zwolinska, p.1015; pl.9, fig. 46

\section{Monosulcites cf. punctatus Orlowska-Zwolinska}

Remarks: The recorded specimens differ from Monosulcites punctatus Orlowska-Zwolinska 1966 in having a thin exine that forms longitudinal folds. Comparable specimens were recorded from Rhaetian and Lower Jurassic strata by Lund (1977) and Dybkjær (1988).
Genus Clavatipollenites Couper 1958

\section{Clavatipollenites hughesii Couper}

1958: Clavatipollenites hughesii-Couper, p.159; pl.31, figs 19-22.

Subturma Praecolpates Potonié \& Kremp 1954

Genus Eucommiidites Erdtman 1948 emend. Hughes 1961

\section{Eucommiidites minor Groot \& Penny}

1960: Eucommiidites minor-Groot \& Penny, p.234; pl.2, fig. 14.

\section{Eucommiidites troedssonii Erdtman}

1948: Eucommiidites troedssonii - Erdtman, p.267; figs 5-10, 13-15.

Turma Poroses (Naumova 1939) Potonié 1960

Subturma Monoporines Naumova 1939

Genus Corollina Maljavkina 1949 emend. Cornet \& Traverse 1975

Remarks: See Dybkjær (1988, p.25) for a discussion of the validity of this genus-name.

Corollina torosus (Reissinger 1950) Klaus 1960 emend.

Cornet \& Traverse 1975

Pl.15, figs 2-5

1950: Pollenites torosus - Reissinger, p.115; pl.14, fig. 20.

1958: Classopollis torosus (Reissinger 1950) - Couper, p.156; pl.28, figs 2-7.

1960: Corollina (al. Pollenites) torosus (Reissinger 1950) - Klaus, p. 168 .

1975: Corollina torosus (Reissinger 1950) - Klaus 1960 emend. Cornet \& Traverse, p.17; pl.5, figs 2-9, 14.

Remarks: In the range-chart this species is subdivided on the basis of its occurrence as single grains ("Corollina torosus, single grains") or in tetrads ("Corollina torosus, tetrads").

Corollina cf. meyeriana (Klaus) Venkatachala \& Góczán

Pl.15, figs 6,7

Remarks: The recorded specimens differ from Corollina meyeriana (Klaus 1960) Venkatachala \& Góczán 1964 in having a weak, but recognizable, internal structure, resulting in an equatorial band composed of fused collumellae, as seen in Corollina torosus.

\section{Aquatic palynomorphs}

The classification used here for the aquatic palynomorphs is in accordance with Tappan (1980). The acritarch-group was subdivided as proposed by Downie, Evitt \& Sarjeant (1963), with the revisions proposed by Diver \& Peat (1979). 
Division Pyrrhophyta Pascher 1914

Class Dinophyceae Fritsch 1929

Remarks: The dinoflagellate cyst species mentioned below are all known from core samples, and could be identified to at least genus level. All other presumed non-caved dinoflagellate cysts recorded have been counted together, and occur as "Other dinoflagellate cysts" in the range-charts.

In addition several presumably caved dinoflagellate cysts were recorded. These occur in the range-charts as "Other dinoflagellate cysts, presumed caved". Some of the species identified to species level are mentioned on p. 16, and are shown on the photo-plates.

\section{Order Nannoceratopsiales Piel \& Evitt 1980}

Genus Nannoceratopsis Deflandre 1938 emend. Piel \& Evitt 1980

Nannoceratopsis gracilis Alberti emend. Evitt Pl.15, fig. 8

1961: Nannoceratopsis gracilis - Alberti, p.30; pl.7, figs. 16, 17. 1961b: Nannoceratopsis deflandrei - Evitt, p.308; pl.1, figs. 2-14. 1962: Nannoceratopsis gracilis (Alberti 1961) - Evitt, p.1129-1130.

\section{Nannoceratopsis ef. senex van Helden} Pl.15, fig. 9

Remarks: Nannoceratopsis senex, erected by van Helden (1977) differs from Nannoceratopsis gracilis in possessing an "extremely rounded outline".... "with only the dorsal antapical horn (well) developed, and in the reduction or absence of the ornamentation (reticulation) on its surface that is characteristic for Nannoceratopsis gracilis Alberti emend.". Piel \& Evitt (1980) stated that the outline is not a practical guide to distinguish Nannoceratopsis senex from Nannoceratopsis gracilis because of overlapping specimens, "although wall structure, when it can be clearly resolved, may be". The specimens referred to Nannoceratopsis cf. senex in the present study show an outline comparable to Nannoceratopsis senex van Helden 1977, but the wall structure is not preserved well enough to allow a safe determination.

Nannoceratopsis cf. pellucida Deflandre emend. Evitt Pl.15, figs 11, 12

Remarks: Only one specimen was recorded, from sample Fj-15,c. This specimen differs from Nannoceratopsis pellucida erected by Deflandre (1938) and emended by Evitt (1961b), in having shorter, and wider antapical horns. It compares very well with the specimens referred to Nannoceratopsis gracilis var. A, by Johnson \& Hills (1973), from a Bajocian sequence on Axel Heiberg Island, Arctic Canada.
Nannoceratopsis sp.1

Pl.15, fig. 10

Description: The main characters of this specimen correspond with the general morphology of the genus Nannoceratopsis, as described by Piel \& Evitt (1980). It differs, however, in having no antapical horns, but a rounded antapical pole. The cyst wall is reticulate, as in Nannoceratopsis gracilis.

Dimensions: length: 68 microns; width: 47 microns (1 specimen).

Remarks: Only one specimen was recorded, from sample St-14,w.

Order Peridiniales Haeckel 1894

Genus Dapcodinium Evitt 1961 emend. Below 1987

Dapcodinium priscum Evitt emend. Below

Pl.15, fig. 13; Pl.16, figs 1, 2

1961a: Dapcodinium priscum - Evitt, p.996; pl.119, figs 1-14

1987: Dapcodinium priscum (Evitt 1961) - Below, p.149; pl.23, figs $6-11,19$

\section{Genus Liasidium Drugg 1978}

Liasidium variabile Drugg

Pl.16, figs 3, 6

1978: Liasidium variabile - Drugg, p.69; pl.4, fig. 10, pl.5, figs 1-9.

Genus Rhaetogonyaulax Sarjeant 1966 emend. Below 1987

Rhaetogonyaulax rhaetica (Sarjeant) Loeblich \& Loeblich emend. Below

Pl.16, figs 4, 5

1963: Gonyaulax rhaetica - Sarjeant, p.353, figs 1, 2 (left).

1968: Rhaetogonyaulax rhaetica (Sarjeant 1963) - Loeblich \& Loeblich p. 212 .

1975: Rhaetogonyaulax rhaetica (Sarjeant 1963) - Harland, Morbey \& Sarjeant, p.862; pl.100-104.

1987: Rhaetogonyaulax rhaetica (Sarjeant 1963) - Below, p. 105, pl.9, figs 1-18, pl. 10, figs 1-18, text-figs 60,61 .

Dinocyst sp.1

Pl.17, fig. 1

Description: A very small dinoflagellate cyst with an ovoid outline. The cingulum is distinct, but no tabulation could be observed. The wall is thin, sculptured with densely spaced micro granulae or -spinae.

Dimensions: 23 (26) 30 microns high (8 specimens). Remarks: This species was commonly recorded from samples referred to Late Pliensbachian - Toarcian.

The following dinoflagellate cyst species were all recorded sporadically, and occur in the range-charts as "Other dinoflagellate cysts". 
Subgroup Netromorphitae Downie, Evitt \& Sarjeant 1963

Escharisphaeridia pocockii (Sarjeant) Erkmen \& Sarjeant

Pl.16, figs 7, 8

1968: Chytroeisphaeridia pocockii - Sarjeant, p.230; pl.3, fig. 9.

1980: Escharisphaeridia pocockii (Sarjeant 1968) - Erkmen \& Sarjeant, p.62.

Remarks: Only one specimen recorded, from sample Fj-16,c. This species has been reported from Upper Callovian strata in England and Scotland (Erkman \& Sarjeant 1980).

\section{Escharisphaeridia sp.}

Pl.16, fig. 9

Description: A relatively small dinoflagellate cyst with an ovoid outline. The paratubulation is relatively distinct. At the apical end, some of the plates are partly broken off, probably functioning as a part of the archaeopyle. The wall structure is finely reticulate.

Dimensions: length: about 40 microns; width: $37 \mathrm{mi}-$ crons (1 specimen).

Remarks: Only one specimen recorded, from sample St-13,w.

Genus Prolixosphaeridium Davey, Downie, Sarjeant \& Williams 1966 emend. Davey 1969

\section{Prolixosphaeridium sp.}

Pl.17, fig. 2

Description: Elongated elliptical outline, with morphological characters as described for this genus by Davey (1969). The wall ornamentation consists of thin processes, pointed or bifurcating, and about 10 microns long.

Dimensions: length: about 67 microns; width: $42 \mathrm{mi}-$ crons (1 specimen).

Remarks: Only one specimen recorded, from sample Frh-14,c.

\section{Group Cryptarcha Diver \& Peat 1979}

Subgroup Sphaeromorphitae Downie, Evitt \& Sarjeant 1963

PI.18, figs 5, 6

\section{Group Acritarcha (Evitt 1963) Diver \& Peat 1979}

Subgroup Acanthomorphitae Downie, Evitt \& Sarjeant 1963

Pl.18, figs 7-9; Pl.19, fig. 1

Subgroup Polygonomorphitae Downie, Evitt \& Sarjeant 1963

Pl.19, figs 2, 4-6

\section{Genus Leiofusa Eisenack 1938}

Leiofusa jurassica Cookson \& Eisenack

Pl.19, fig. 3

1958: Leiofusa jurassica - Cookson \& Eisenack, p.51; pl.10, figs 3, 4

Remarks: This species is treated separately as it probably has stratigraphical potential, see p.38.

\section{? Group Acritarcha:}

Genus Schizocystia Cookson \& Eisenack 1962

Schizocystia rara Playford \& Dettmann 1965 Pl.20, fig. 3

Remarks: This species is referred to the Group Acritarcha, as the origin is unknown. However, it does not seem to belong to any of the above mentioned Subgroups or to any other Subgroup known to the author.

Genus Diexallophasis Loeblich 1970

Diexallophasis denticulata (Stockmans \& Williére) Loeblich 1970. Pl.19, fig. 8

1963: Baltisphaeridium denticulatum - Stockmans \& Williére

1970: Diexallophasis denticulata (Stockmans \& Williére 1963) - Loeblich

Remarks: Only one specimen was recorded, from sample St-17,w. This specimen is probably reworked. The acritarch species Diexallophasis denticulata is known from Silurian and Devonian strata from several localities in North America and Europe (e.g. Reaugh 1978, Smelror 1987).

Genus Multiplicisphaeridium Staplin 1961 emend. Staplin, Jansonius \& Pocock 1965

\section{Multiplicisphaeridium sp.}

Pl.19, fig. 9

Description: The vesicle is circular in outline, about 30 microns in diameter, and with a laevigate wall surface. It is sculptured with about 20 hollow, laevigate processes, that open into the vesicle interior. At their base the processes are 3-4 microns in diameter; they are about 10 microns long, furcating in the outermost 2-3 microns, up to third order. The tips are pointed, some of them are distinct, while others are delicate.

Dimensions: diameter: about 50 microns ( 1 specimen). Remarks: Only one specimen was recorded, from sample Frh-19,c. This specimen is probably reworked. The acritarch genus Multiplicisphaeridium is known from Silurian and Devonian strata in the U.S.A. and Europe (e.g. Dorning 1981, Wicander \& Playford 1985, Smelror 1987). 
Division Prasinophyta Round 1971

Order Pterospermatales Schiller 1925

Family Tasmanaceae Sommer 1956

Family Cymatiosphaeraceae Mädler 1963

Genus Schizosporis Cookson \& Dettmann 1959

Schizosporis reticulatus (Cookson \& Dettmann) emend. Pierce

Pl.20, fig. 4

1959: Schizosporis reticulatus - Cookson \& Dettmann, p.213; pl.1, figs 1-4

1974: Schizosporis reticulatus - (Cookson \& Dettmann 1959) emend. Pierce, p. 27.

Remarks: According to Pierce the stratigraphical range of this species is Berriasian to Cenomanian-Turonian or possibly Maastrichtian. In the present study it was recorded from the core sample Frh-18,c, referred to the Toarcian.

Genus Cymatiosphaera (Wetzel 1932) Deflandre 1954 Pl.20, fig. 2

Remarks: Mentioned in the range-charts as Cymatiosphaera spp.

Family Pterospermellaceae Eisanack 1972

Genus Pterospermella Eisenack 1972

Remarks: Mentioned in the range-charts as Pterospermella spp.

Division Chlorophyta Pascher 1914

Class Chlorophyceae Kützing 1843

Family Botryococcus Wille 1909

Genus Botryococcus Kützing 1849

Pl.20, fig. 1

Remarks: Mentioned in the range-charts as Botryococcus spp.

\section{Other microfossils}

Foraminiferal test-linings.

Pl.20, fig. 5

Fungi-remains

Pl.20, fig. 6

Species indet., type 1

Pl.19, fig. 10

Description: Elliptical to circular outline. A rounded triangular aperture (Pylome?) with a diameter of about $1 / 3$ of the total diameter. The exine is punctate to granulate.

Dimensions: length: 50 microns; width: 40 microns (1 specimen).

Remarks: Not mentioned in the range-charts. Only one specimen recorded, from sample Frh-13,c.

Species indet., type 2

Pl.20, figs 7,8

Description: Elliptical to circular outline. No apertures. A girdle, about 8 microns wide surrounds the grain. The exine is about 1 micron thick, sculptured with sparse, but regularly spaced, baculae, about 1 micron wide, 4 microns high.

Dimensions: length: about 72 microns; width: $60 \mathrm{mi}-$ crons (excluding the girdle) (1 specimen).

Remarks: Not mentioned in the range-charts. Only one specimen recorded, from sample Frh-16,c. 


\section{Introduction}

On the basis of the variations in the microflora assemblages in the core samples from the Fjerritslev-2, Frederikshavn-2, and Stenlille-2 boreholes, five spore/ pollen zones and four dinoflagellate cyst zones are proposed (fig. 6). This zonation is based on first appearances, last appearances, abundance variations, and associations of specific taxa.

The relative abundance of marine palynomorphs, the mutual variations of the main morphological groups of terrestrial palynomorphs (spores, saccate and non-saccate pollen), and of the different types of aquatic palynomorphs (appendices A-D; figs 13, 15, 17) have been used to characterize the proposed zones. The usefulness of the proposed zonation throughout the Danish Subbasin, has been evaluated by comparison with earlier palynological investigations of Lower Jurassic sequences in the Danish region. These investigations comprise the Gassum-1 borehole (Evitt 1961a, 1961b, Dybkjær 1988), the Rødby-1 borehole (Lund 1977), and the Hobro-1 borehole (Bertelsen 1979).

The proposed dating of the zones is based on results from earlier palynological investigations of ammonite(or other macrofossils) or microfossil-dated sequences in northwest Europe (figs 4 and 5).

The proposed spore/pollen zonation is correlated with earlier palynologically zoned sequences from northwest Europe. The most important references for correlation of the spore/pollen zones are Schulz (1967), Orbell (1973), Morbey $(1975,1978)$, Lund (1977), Bertelsen (1979), Hoelstad (1985), Lund \& Pedersen (1985), and Dybkjær (1988) (fig. 6).

The proposed dinoflagellate cyst zonation is correlated with the zonation proposed by Morbey (1978), and Woollam \& Riding (1983) (fig. 6).

\section{Definition of spore-pollen zones}

Four new spore/pollen zones are proposed: the Corollina-Ricciisporites Zone, the Cerebropollenites macroverrucosus Zone, the Spheripollenites - Leptolepidites Zone, and the Perinopollenites elatoides Zone. These zones, and the Pinuspollenites - Trachysporites Zone Lund 1977, are proposed for use in the entire Danish Subbasin.

\section{The Corollina - Ricciisporites Zone}

Occurrence: Fjerritslev-2, samples $\mathrm{Fj}-2, \mathrm{c}$ and $\mathrm{Fj}-3, \mathrm{c}$ (2304m-2303m b.r.t.), Frederikshavn-2, sample Frh-1,c (930m b.r.t.), and Stenlille-2, samples St-1,c to St-3,c (1513m-1510m b.r.t.).

Reference section: The Fjerritslev-2 borehole, 2304m-2303m (samples Fj-2,c and Fj-3,c).

Base: The base of this zone is not defined here.

Top: Immediately below the distinct increase of $\mathrm{Pi}$ nuspollenites minimus and of sculptured, trilete spores, and the decrease of Corollina torosus, defining the base of the Pinuspollenites - Trachysporites Zone.

Characteristics: This zone is characterized by the dominance of Corollina torosus together with a common occurrence of Ricciisporites tuberculatus.

The remaining assemblage is dominated by, mainly, Early Jurassic species, such as Deltoidospora toralis, Stereisporites stereoides, Intrapunctisporis toralis, Monosulcites punctatus, Pinuspollenites minimus, Perinopollenites elatoides, Marattisporites scabratus, and Aratrisporites minimus. The small bisaccate species $V i$ treisporites pallidus, known from the Late Permian to the Early Cretaceous, was also recorded frequently. Furthermore this zone is characterized by the sporadic to common occurrence of mainly Rhaetian species, such as Polypodiisporites polymicroforatus, Taneaesporites sp., Zebrasporites laevigatus, Densosporites fissus, Densosporites cavernatus, Ovalipollis ovalis, Cingulizonates rhaeticus, Camarozonosporites rudis, Semiretisporis goetae, Triancoraesporites reticulatus, Triancoraesporites ancorae, Limbosporites lundbladii, and $\mathrm{Pe}$ rinosporites thuringiacus.

The terrestrial palynomorphs are dominated by nonsaccate pollen (mainly due to the acme of Corollina torosus, and Ricciisporites tuberculatus) (figs 13,15 and 17 ), while the saccate pollen only constitute a minor part of the assemblage.

The aquatic palynomorphs are dominated by acanthomorphe and polygonomorphe acritarchs, and by the dinoflagellate cyst species Dapcodinium priscum. Furthermore, the sporadic to common occurrence of Rhaetogonyaulax rhaetica, Leoifusa jurassica, Tasmanites, and Botryococcus is often recorded. 


\begin{tabular}{|c|c|c|c|c|c|c|c|c|c|c|}
\hline \multirow{3}{*}{$\begin{array}{l}\text { STRATIGRAPHICALLY } \\
\text { IMPORTANT } \\
\text { SPORE / POLLEN - } \\
\text { TAXA }\end{array}$} & \multirow{3}{*}{$\begin{array}{l}\text { CHRONOSTRATI- } \\
\text { GRAPHY } \\
\text { LITERATURE } \\
\text { USED FOR } \\
\text { CORRELATION }\end{array}$} & \multirow{2}{*}{\multicolumn{2}{|c|}{$\begin{array}{l}\text { UPPER } \\
\text { TRIASSIC }\end{array}$}} & \multirow{2}{*}{\multicolumn{4}{|c|}{ 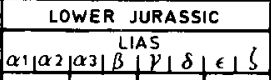 }} & \multirow{2}{*}{\multicolumn{3}{|c|}{ MIDDLE JURASSIC }} \\
\hline & & & & & & & & & & \\
\hline & & 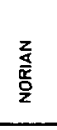 & 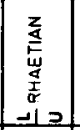 & 㶪 & 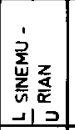 & 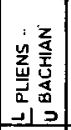 & 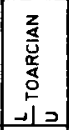 & $\frac{2}{\stackrel{2}{2}}$ & 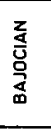 & 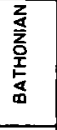 \\
\hline $\begin{array}{l}\text { RHAE TIPOLLIS } \\
\text { GERMANICUS }\end{array}$ & 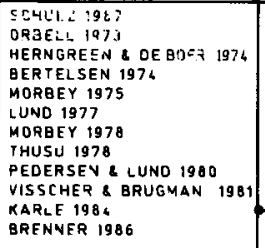 & & \begin{tabular}{|c|}
- \\
- \\
$-\cdots$
\end{tabular} & & & & & & & \\
\hline $\begin{array}{l}\text { GRANULOPERCULATI - } \\
\text { POLLIS } \\
\text { RUDIS }\end{array}$ & $\begin{array}{l}\text { ORBEL } 1973 \\
\text { BERTELSEN } \\
\text { MORBEY } 1979 \\
\text { LUNO } 1977 \\
\text { MOREEY } 1978 \\
\text { THUSU } 1978\end{array}$ & 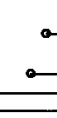 & $\frac{0}{\cdots}$ & & & & & & & \\
\hline & 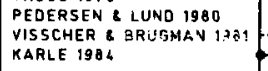 & $\ldots \ldots$. & $E$ & & & & & & & \\
\hline $\begin{array}{l}\text { OVALIPOLLIS } \\
\text { OVALIS }\end{array}$ & 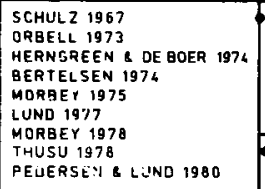 & …. & 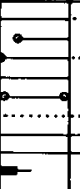 & & $?$ & ?? & $?$ & & & \\
\hline $\begin{array}{l}\text { RICCISPORITES } \\
\text { TUBERCULATUS }\end{array}$ & 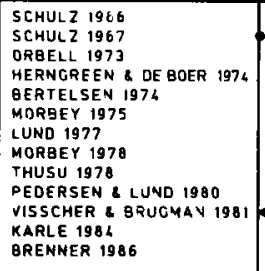 & - & $\begin{array}{l}-1 \\
-1 \\
-1 \\
-1 .\end{array}$ & ? & $\because \cdots$ & $\cdots$ & & & & \\
\hline $\begin{array}{l}\text { CAMAROZONOSPORITES } \\
\text { LAEVIGATUS }\end{array}$ & $\begin{array}{l}\text { SCHULZ } 1966 \\
\text { SCHULZ } 1967 \\
\text { OREEL } 1973 \\
\text { LUND } 1977\end{array}$ & & $\ldots \ldots$ & & & & & & & \\
\hline $\begin{array}{l}\text { CAMAROZONOSPOFITES } \\
\text { RUDIS }\end{array}$ & $\begin{array}{l}\text { SCHULZ } 1967 \\
\text { OREEL } 19973 \\
\text { MOREY } 1975 \\
\text { LUND 1977 } \\
\text { VISSCHER \& BRUGMAN 1981 }\end{array}$ & & & & & & & & & \\
\hline $\begin{array}{l}\text { LIMBOSPORITES } \\
\text { LUNOBLADII }\end{array}$ & 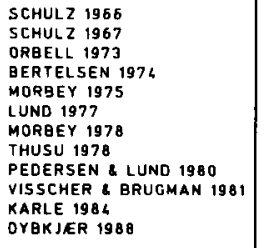 & & $\cdots .$. & ? & & & & & & \\
\hline $\begin{array}{l}\text { PERINOSPORITES } \\
\text { THORINGIACUS }\end{array}$ & $\begin{array}{l}\text { SCHULZ } 1966 \\
\text { SCHULZ } 1967 \\
\text { ORBELL } 1973 \\
\text { LUND 1977 } \\
\text { MOREEY 1978 } \\
\text { KARLE 1986 }\end{array}$ & & …... & & & & & & & \\
\hline $\begin{array}{l}\text { SEMIRETISPORIS } \\
\text { GOTHAEE }\end{array}$ & 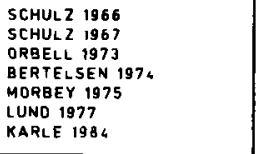 & & $-\ldots$ & -? & & & & & & \\
\hline $\begin{array}{l}\text { TRIANCORAESPORITES } \\
\text { ANCORAE }\end{array}$ & 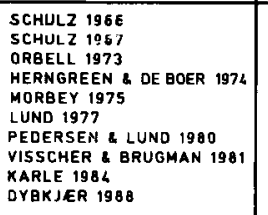 & & $\ldots$ & $F$ & & & & & & \\
\hline $\begin{array}{l}\text { OENSOSPORITES } \\
\text { CAVERNATUS }\end{array}$ & $\begin{array}{l}\text { SCHULZ } 1966 \\
\text { SCHULZ } 1967 \\
\text { ORBEL } 1973 \\
\text { LUND 19977 } \\
\text { PUDERSEN \& LUND 1980 }\end{array}$ & & 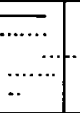 & & & & & & & \\
\hline $\begin{array}{l}\text { OENSOSPORITES } \\
\text { FISSUS }\end{array}$ & 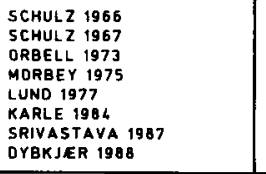 & & ….... & & & & & & & \\
\hline $\begin{array}{l}\text { 2EBRASPORITES } \\
\text { LAEVIGATUS }\end{array}$ & $\begin{array}{l}\text { SCHULZ } 1966 \\
\text { SCHULZ } 1967 \\
\text { ORBELL L } 1973 \\
\text { MOREEY } \\
\text { LUND 1977 }\end{array}$ & & 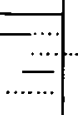 & & & & & & & \\
\hline
\end{tabular}

Fig. 4. Ranges of stratigraphically important sporeand pollen species, according to the literature. The chronostratigraphical subdivision indicated with greek letters is the old German subdivision of the Lower Jurassic (Lias). 


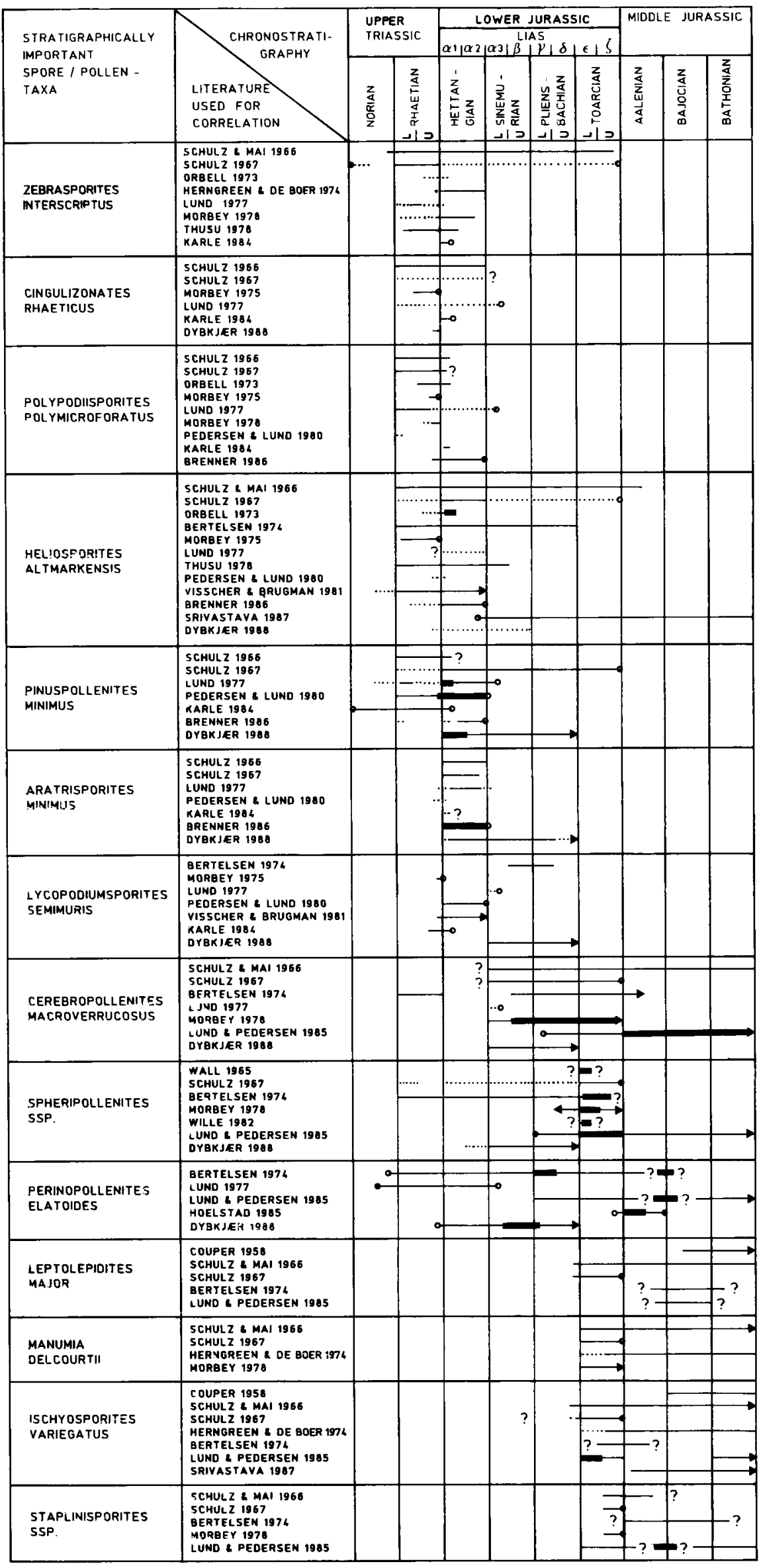




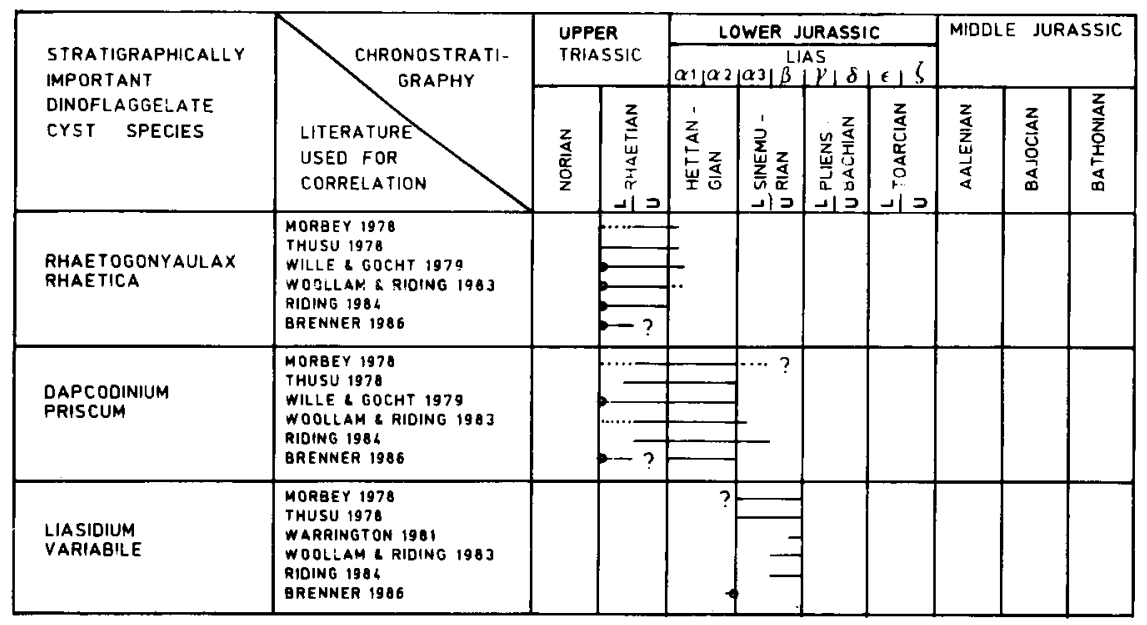

Fig. 5. Ranges of stratigraphically important dinoflagellate cyst species, according to the literature. See text to fig. 4 for further explanation.
Suggested age: This zone can be assigned a Late Rhaetian age. The palynomorph assemblage corresponds very well with several other latest Late Rhaetian assemblages from northwest Europe. These include the "Oberrät" micro-flora from the North German Basin described by Schulz (1967) (= Zone 3 in fig. 6), the upper part of the Rhaetipollis Zone from England (Orbell 1973), and the lowermost part of the FG-Subzone defined in the Kendelbachgraben, Austria (Morbey 1975).

The "Upper Rhaetic" microflora assemblage named as the Ricciisporites - Polypodiisporites Zone, defined by Lund (1977), is characterized by the common occurrence of either Polypodiisporites polymicroforatus or Semiretisporis. These two taxa only occur sporadically in the Corollina-Ricciisporites Zone in this study.

$\begin{array}{lll}\text { CHRONO - } & \text { LITHO - } & \text { OSTRACOD - } \\ \text { STRATI - } & \text { STRATI - } & \text { ZONATION } \\ \text { GRAPHY } & \text { GRAPHY } & \\ & (\text { MICHELSEN } \\ & 1978,1989) & (\text { MICHELSEN } \\ & 1975)\end{array}$

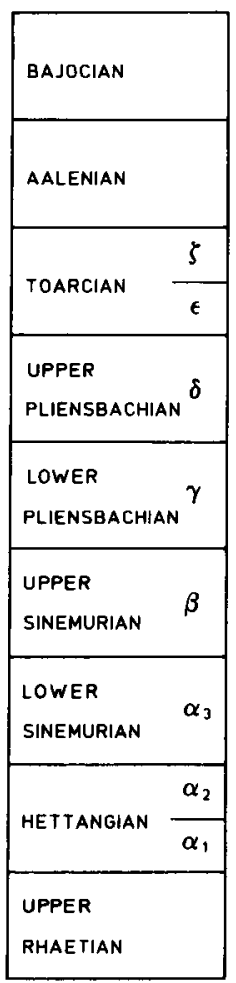
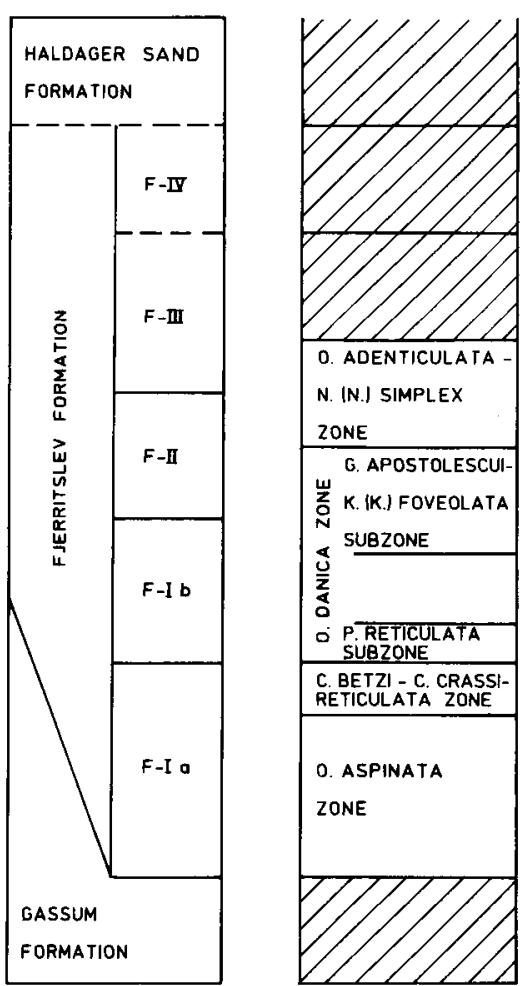

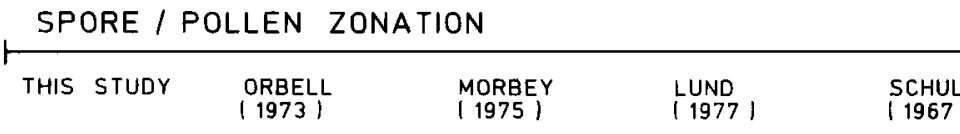

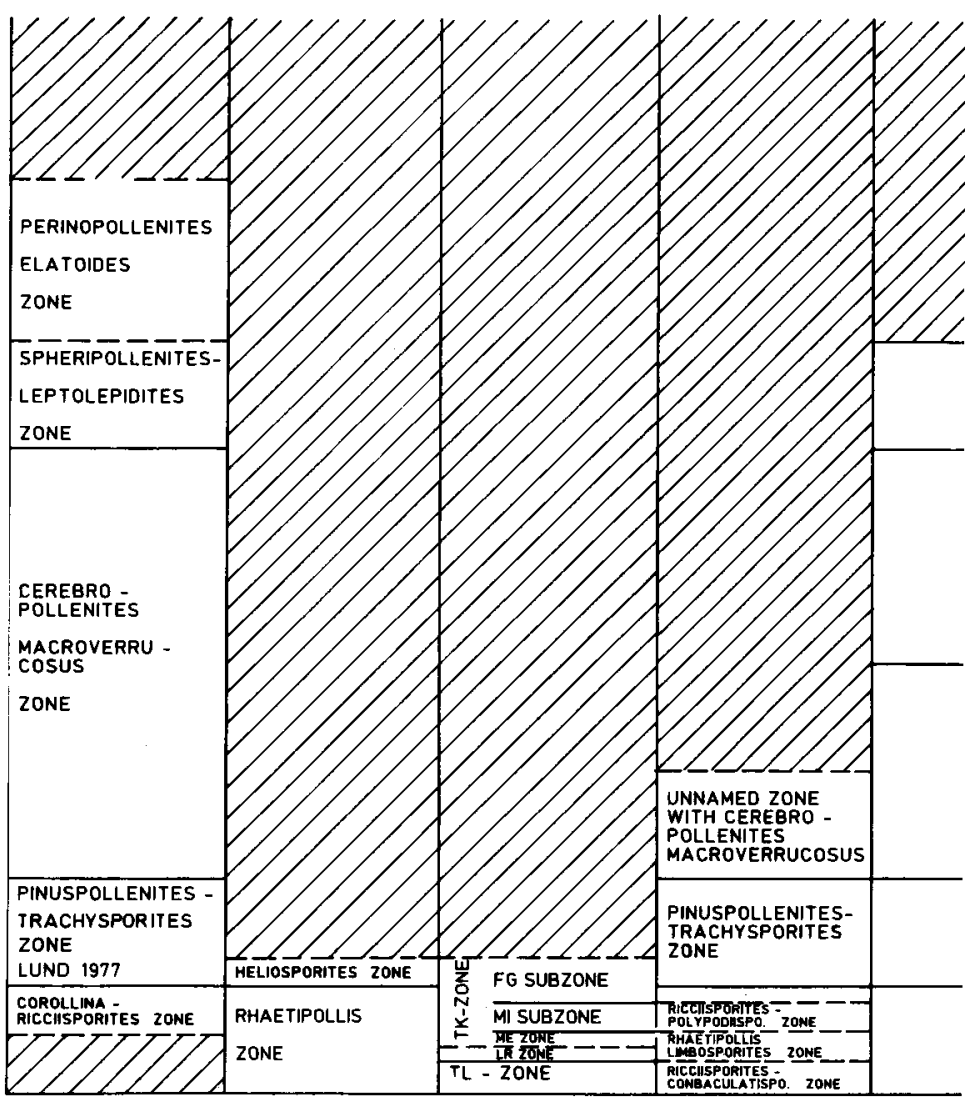

Fig. 6. Correlation of the spore/pollen zonation and dinoflagellate cyst zonation proposed here, with previous bio-zonations from Northwestern Europe. The chronostratigraphical subdivision indicated with greek letters is the old German subdivision of the Lower Jurassic (Lias). 
In the present study Deltoidospora toralis dominates the assemblage, and, in addition to the taxa mentioned above, the species Perinopollenites elatoides, Corollina torosus, and Marattisporites scabratus occur frequently, while the species Calamospora tener, Stereisporites stereoides, Monosulcites punctatus, Punctatisporites globosus, Vitreisporites pallidus, Deltoidospora minor, Aratrisporites minimus, Perinopollenites cf. elatoides, Intrapunctisporis toralis, Alisporites robustus, and the genus Chasmatosporites are common. The mainly Rhaetian species Zebrasporites interscriptus, and Ricciisporites tuberculatus occur sporadically in the lower part of the zone, while the other mainly Rhaetian species that characterize the Corollina - Ricciisporites Zone are not recorded.

In general spores dominate the spore/pollen assemblage, whereas bisaccate pollen, and non-saccate pollen constitute a minor part.

The aquatic palynomorphs are dominated by acritarchs, especially acanthomorphe, polygonomorphe, and sphaeromorphe types. Dapcodinium priscum is relatively abundant, while Rhaetogonyaulax rhaetica was not recorded. Tasmanites and Botryococcus occur sporadically, and the polygonomorphe acritarch species Leiofusa jurassica is recorded in high numbers in the lower part of the Stenlille-2 borehole, in sample St-8,c.

Suggested age: Hettangian. Lund (1977) dated the $P i$ nuspollenites - Trachysporites Zone as Hettangian. Furthermore, Schulz (1967), Pedersen \& Lund (1980), Brenner (1986), and Dybkjær (1988) recorded distinctly higher abundances of Pinuspollenites minimus in the Hettangian than in the Rhaetian (see fig. 4). In the Rødby-1 borehole as well as in the Northwest German Basin (Lund 1977) an acme of Leiofusa jurassica was recorded from the basal part of the PinuspollenitesTrachysporites Zone. This level could possibly be correlated with the acme of Leiofusa jurassica in Stenlille-2.

Comparison with other zonations proposed for the Danish region: The Pinuspollenites - Trachysporites Zone Lund 1977 correlates very well with the C1 Unit in the Hobro-1 borehole (Bertelsen 1979). Zone B in the Gassum-1 borehole (Dybkjær 1988) compares rather well, but is dominated by Corollina torosus rather than Deltoidospora toralis.

\section{The Cerebropollenites macroverrucosus Zone}

Occurrence: In Fjerritslev-2, samples Fj-5,c to Fj-12,c (2105m-2003m b.r.t.), in Frederikshavn-2, samples Frh-2,c to Frh-14,c (892m-851m b.r.t.), and in Stenlille-2, samples St-9,w to St-14,w (1390m-1240m b.r.t.).

Reference section: The Frederikshavn-2 borehole, $892 m-851 m$ b.r.t. (samples Frh-2,c to Frh-14,c).
Base: At the first appearance of Cerebropollenites macroverrucosus.

Top: Immediately below the distinct rise in the genera Spheripollenites, and first appearance of either the genus Leptolepidites or Ischyosporites, or both.

Characteristics: This zone is characterized by the (often sporadic) presence of Cerebropollenites macroverrucosus.

The species Corollina torosus, Pinuspollenites minimus, Perinopollenites elatoides, and Deltoidospora toralis occur frequently, while Calamospora tener, Marattisporites scabratus, Deltoidospora minor, Aratrisporites minimus, Punctatisporites globosus, Lycopodiumsporites austroclavatidites, Alisporites robustus, Araucariacidites australis, Cerebropollenites thiergartii, Intrapunctisporis toralis, Eucommiidites troedssonii, Monosulcites punctatus, and the genus Chasmatosporites all occur commonly. The species Lycopodiumsporites semimuris often appears immediately below, or at the base of this zone.

Generally the non-saccate pollen show a slightly higher abundance than spores and bisaccate pollen in this zone, but there are no distinct differences in the relative abundances of the three main groups.

The aquatic palynomorphs are dominated by acanthomorphe and polygonomorphe acritarchs. Furthermore the dinoflagellate cyst species Dapcodinium priscum, Liasidium variabile, and Nannoceratopsis gracilis are recorded at different levels and/or from different boreholes in sections all referred to the Cerebropollenites macroverrucosus Zone.

Suggested age: Sinemurian - Pliensbachian. The first appearance of Cerebropollenites macroverrucosus was recorded at the Hettangian-Sinemurian boundary by Schulz (1967), Lund (1977), Morbey (1978), and Dybkjær (1988) (see fig. 4). The specimens recorded by Orbell (1973) from Late Rhaetian do not belong to this species (see p. 27 in the systematic section). Bertelsen (1979) recorded Cerebropollenites macroverrucosus from two sidewall core samples, dated as Late Triassic on the basis of the palynomorph assemblage in the Hobro-1 borehole. A study of these slides by the author confirmed the occurrence of Cerebropollenites macroverrucosus together with a palynomorph assemblage that clearly indicated a Late Triassic age. These observations could be due to contamination, but it is clear that the range of this species in the Danish area should be investigated further. The distinct rise in abundance of Spheripollenites, defining the top of this zone, is probably of Early Toarcian age, as discussed below.

Comparison with previous zonations proposed for the Danish region: The Unit $\mathrm{C} 2$ in Hobro-1 (Bertelsen 1979), the "unnamed zone with Cerebropollenites macroverrucosus" in Rødby-1 (Lund 1977), and Zone C in 
the Gassum-1 borehole (Dybkjær 1988) (fig. 6) all compare well with the Cerebropollenites macroverrucosus Zone.

\section{The Spheripollenites - Leptolepidites Zone}

Occurrence: In Fjerritslev-2, sample Fj-15,c (1561m b.r.t.), in Frederikshavn-2, samples Frh-17,c to Frh-22,c (787m-782m b.r.t.), and in Stenlille-2, samples St-15,w, and St-16,w (1234m-1228m b.r.t.).

Reference section: The Stenlille-2 borehole, $1234 \mathrm{~m}-1228 \mathrm{~m}$ b.r.t. (samples St-15,w and St-16,w).

Base: At a distinct increase in Spheripollenites, and the first appearance of Leptolepidites and/or Ischyosporites.

Top: Immediately below a distinct increase in Perinopollenites elatoides and a decrease in Spheripollenites psilatus.

Characteristics: A high abundance of Spheripollenites and the presence of specimens of either Leptolepidites or Ischyosporites. According to Lund \& Pedersen (1985) the maximum of Spheripollenites in the Early Toarcian coincides with a maximum of Corollina, and a minimum of bisaccate pollen. This tendency was clearly seen in this study, as discussed for the assemblages from the individual boreholes.

In addition to the taxa mentioned above, Perinopollenites elatoides occurs frequently, and the following taxa are common: Deltoidospora toralis, Deltoidospora minor, Araucariacidites australis, Monosulcites punctatus, Cerebropollenites macroverrucosus, Marattisporites scabratus, Calamospora tener, and species of the genus Chasmatosporites. The assemblage includes (sporadically) specimens referred to the stratigraphically important taxa Manumia delcourtii and Staplinisporites telatus, both known from the earliest Toarcian, and younger sequences.

The samples referred to this zone are generally characterized by a clear dominance of non-saccate pollen, and sparse bisaccate pollen.

The aquatic palynomorph assemblage is far more diverse at this level than in the preceeding zones, comprising Cymatiosphaera, Pterospermella, Leiofusa jurassica, Tasmanites, and the limnic algae Botryococcus and Schizosporis reticulatus. Acanthomorphe acritarchs occur in relatively lower numbers than in the preceeding zones, while the dinoflagellate cyst species Nannoceratopsis gracilis and Dinocyst sp. 1 are recorded commonly, and dominate the marine assemblage at some levels. Nannoceratopsis cf. senex is recorded sporadically in some samples.

Suggested age: Toarcian. The relatively high abundance of Spheripollenites psilatus, (especially in
St $-15, w$, and St-16,w) may possibly be related to the Early Toarcian anoxic event. A mass occurrence of small, spherical bodies, comparable to the genus Spheripollenites, is known from layers deposited during the Early Toarcian anoxic event over wide areas of northwest Europe: from Yorkshire, England ("Inaperturopollenites orbiculatus" and "Inaperturopollenites globulus") (Wall 1965); from Swabia, southwest Germany ("Inaperturopollenites orbiculatus", reaching a dominance of $99 \%$ !) (Wille 1982); and from Jameson Land, East Greenland (Spheripollenites subgranulatus) (Lund \& Pedersen 1985).

The relatively low record of acritarchs, the dominance of Nannoceratopsis gracilis, and the occurrence of several taxa of the Prasinophyta, compare well with the observations from earlier investigations of Lower Toarcian deposits from western Germany. According to Riegel et al. (1986), the Posidonia Shale is characterized by a greatly reduced number of acritarchs, while Nannoceratopsis gracilis is the only recorded dinoflagellate cyst species. Wille \& Gocht (1979) recorded a few species of non excysted dinoflagellate cysts, together with specimens referable to the Division Prasinophyta (Tasmanaceae, Cymatiosphaeraceae, Leiosphaeridiaceae, Pterospermellaceae), and small acritarchs.

The first appearance of taxa such as Leptolepidites, Ischyosporites, Klukisporites, Manumia, Staplinisporites, and Clavatipollenites hughesii in this zone, clearly indicates an Early Toarcian age (Couper 1958, Schulz 1967, Herngren \& de Boer 1974, Morbey 1978, Hoelstad 1985, Lund \& Pedersen 1985) (fig. 4). Zone B from the Vardekløft Ravine, Jameson Land, East Greenland (Lund \& Pedersen 1985) (fig. 6), referred to Early Toarcian (to Late Pliensbachian), consisted of an assemblage that compares very well to the Spheripollenites - Leptolepidites Zone, with $75 \%$ Spheripollenites, the first appearance of Leptolepidites bossus, Ischyosporites variegatus, and of Manumia spp.

Comparison with previous zonations proposed for the Danish region: The upper part of Bertelsen's (1979) Unit C4 from the Hobro-1 borehole (fig. 6) corresponds very well to the Spheripollenites - Leptolepidites Zone. More than $50 \%$ Spheripollenites was recorded in the sample which represents the upper part of Unit C4. The associated trend, as mentioned above, towards an increase in the relative abundance of Corollina and a decrease in bisaccate pollen grains, was also recognizable in the Hobro-1 borehole, where the relative abundance of the genus Corollina increased from $2.5 \%$ in the preceeding sample to $10.4 \%$, and the bisaccate pollen grains showed an exceptionally low value of $2 \%$ of the total spore/pollen assemblage. The first appearance of Ischyosporites variegatus in this sample further comfirms the correlation.

Palynomorph assemblages comparable to the Spheri- 
pollenites - Leptolepidites Zone are also present in the Haldager-1 and Børglum-1 boreholes (Helle Ravn S $\emptyset$ rensen, pers. comm., 1989) at levels that have been referred to the late Early Jurassic-lowermost Middle Jurassic (Sorgenfrei \& Buch 1964).

\section{The Perinopollenites elatoides Zone}

Occurrence: In Fjerritslev-2, sample Fj-16,c (1329m b.r.t.).

Reference section: The Fjerritslev-2 borehole, $1329 \mathrm{~m}$ b.r.t. (sample Fj-16,c).

Base: At a distinct increase in abundance of Perinopollenites elatoides, and a concurrent decrease in Corollina torosus and Spheripollenites psilatus.

Between this zone and the previous one, there is a $232 \mathrm{~m}$ interval (in the Fjerritslev-2 borehole) without any core recovery. The flora recorded from the cuttings samples from this interval (samples Fj-32,s, Fj-35,s, and $\mathrm{Fj}-38, \mathrm{~s}$ ) shows a gradual increase in the relative abundance of Perinopollenites elatoides and a concurrent decrease of Corollina torosus and Spheripollenites psilatus, indicating that the Perinopollenites elatoides Zone succeeds the Spheripollenites - Leptolepidites Zone.

Top: The top of this zone is not defined in the present study. Hoelstad's (1985) definition of the boundary between his zone II and III could be adopted. This boundary is defined primarily by the concurrent increase in relative abundance of Corollina torosus and Contignisporites problematicus (junior synonym to Crassitudisporites problematicus (Couper 1958) Hiltman 1967, see p. 25).

Characteristics: Dominance of Perinopollenites elatoides, and a relatively low abundance of Corollina torosus, and of bisaccate pollen.

The genus Spheripollenites is recorded frequently, while the following species occur commonly: Deltoidospora toralis, Pinuspollenites minimus, Marattisporites scabratus, Intrapunctisporis toralis, Deltoidospora minor, Araucariacidites australis, Monosulcites punctatus, Alisporites robustus, Monosulcites cf. punctatus, Exesipollenites tumulus, Clavatipollenites hughesii, and the genus Chasmatosporites. The species Ischyosporites variegatus, Manumia delcourtii, Leptolepidites major, and Staplinisporites telatus, known from the latest Early Jurassic or younger strata, occur sporadically. Generally the non-saccate pollen dominate the spore/pollen assemblage, while the saccate pollen and the spores form only a minor part.

The aquatic palynomorphs are dominated by acanthomorphe acritarchs. Nannoceratopsis gracilis and Nannoceratopsis cf. senex were recorded sporadically.
Suggested age: Middle Jurassic. Leptolepidites major and Manumia delcourtii are both known to appear at the Pliensbachian-Toarcian boundary (Schulz \& Mai 1966, Schulz 1967, Herngren \& de Boer 1974, Morbey 1978) (fig. 4). Ischyosporites variegatus is known from the Toarcian in North Germany and in the Netherlands (Schulz 1967, Herngren \& de Boer 1974), from the Toarcian-Aalenian boundary in France (Srivastava 1987), and from the Bajocian in Britain (Couper 1958). Staplinisporites telatus is known from the upper part of the Toarcian (Schulz 1967, Morbey 1978, Lund \& Pedersen 1985).

The Perinopollenites elatoides Zone corresponds rather well to the lower part of Hoelstad's (1985) Zone II from Bornholm, which has been assigned an Aalenian age (fig. 6). The lower part of Hoelstad's Zone II is characterized, in part, by relatively high abundances of Perinopollenites elatoides, and the concurrent occurrence of all recognized species of the genera Leptolepidites and Lycopodiumsporites. Furthermore, the species Manumia delcourtii (= Manumia variverrucata) first appear at the lower boundary of Hoelstad's (1985) Zone II, together with several other mainly Middle Jurassic species, many of which, however, were not recorded in this study. Zone II is also characterized by a high relative abundance of pollen (mainly non-saccate) relative to spores, which is also the case in the Perinopollenites elatoides Zone.

Bertelsen's (1979) Zone D from the Hobro-1 borehole, dated as Middle Jurassic, is characterized by a dominance of Perinopollenites elatoides, and by a complete absence of Corollina. In addition, several, mainly Middle Jurassic taxa, including Manumia delcourtii (= Converrucosisporites variverrucatus) and Leptolepidites major were recorded by Bertelsen at this level.

A maximum of Perinopollenites elatoides was recorded from Subassemblage C1 (Lund \& Pedersen 1985) from the Vardekløft Ravine, Jameson Land, East Greenland, together with Leptolepidites bossus and Leptolepidites major. This subassemblage was assigned a Middle to Late Bajocian age. The sporadic record of Nannoceratopsis gracilis and Nannoceratopsis cf. senex indicates an age not younger than the Bathonian-Callovian boundary (Schulz \& Mai 1966, Thusu 1978, Woollam \& Riding 1983) (fig. 5).

Comparison with previous zonations proposed for the Danish region: The Perinopollenites elatoides Zone can possibly be correlated with Bertelsen's (1979) Zone D from the Hobro-1 borehole (fig. 6). Furthermore, palynomorph assemblages comparable to the Perinopollenites elatoides Zone have been recorded in the Børglum-1 and Haldager-1 boreholes, immediately above a level comparable with the Spheripollenites - Leptolepidites Zone as defined here (Helle Ravn Sørensen, pers. comm. 1989). 


\section{Definition of dinoflagellate cyst zones}

Four dinoflagellate cyst zones are defined (fig. 6): The Rhaetogonyaulax rhaetica Zone, the Dapcodinium priscum Zone, the Liasidium variabile Zone, and the Nannoceratopsis gracilis Zone. They are all recognizable in several sections in the Danish region, and are therefore preliminarily proposed for use throughout the Danish Subbasin. Previous records of the stratigraphically most important species in the Danish region are briefly mentioned.

\section{The Rhaetogonyaulax rhaetica Zone}

Occurrence: In Fjerritslev-2, samples Fj-2,c and Fj-3,c (2304m-2303m b.r.t.), and in Stenlille-2, samples St-1,c to St-3,c (1513m-1510m b.r.t.).

Reference section: The Fjerritslev-2 borehole, 2304m-2303m b.r.t. (samples Fj-2,c and Fj-3,c).

Base: At the first joint occurrence of the two species Rhaetogonyaulax rhaetica and Dapcodinium priscum.

Top: At the last occurrence of Rhaetogonyaulax rhaetica.

Characteristics: This zone is characterized by the presence together of the species Rhaetogonyaulax rhaetica and Dapcodinium priscum. Other dinoflagellate cyst species occur only sporadically.

Suggested age: Rhaetian. The Rhaetogonyaulax rhaetica Zone proposed by Woollam \& Riding (1983) (defined by the presence and abundance of Rhaetogonyaulax rhaetica), was dated as Rhaetian. The Rhaetogonyaulax rhaetica Zone proposed by Morbey (1978) was dated as Rhaetian to earliest Hettangian (fig. 6). The range of Rhaetogonyaulax rhaetica and Dapcodinium priscum according to the literature is shown in fig. 5 .

Comparison with earlier recordings in the Danish region: In the Gassum-1 borehole the association of Rhaetogonyaulax rhaetica and Dapcodinium priscum was recorded from two samples, taken at $1587 \mathrm{~m}$ and $1588 \mathrm{~m}$ b.r.t. (Marianne Vasard Nielsen, pers. comm., 1988).

\section{The Dapcodinium priscum Zone}

Occurrence: In Fjerritslev-2, sample Fj-4,c (2106m b.r.t.), in Frederikshavn-2, samples Frh-1,c to Frh-12,c (930m-880m b.r.t.), and in Stenlille-2, samples St-5,c to St-9,w (1496m-1390m b.r.t.).

Reference section: The Stenlille-2 borehole, $1496 m-1390$ m b.r.t. (samples St-5,c to St-9,w).

Base: Immediately above the last occurrence of Rhaetogonyaulax rhaetica.
Top: At the last occurrence of Dapcodinium priscum.

Characteristics: This zone is characterized by the presence of Dapcodinium priscum, and the absence of Rhaetogonyaulax rhaetica. Other dinoflagellate cyst species occur only sporadically.

Suggested age: latest Rhaetian to earliest Sinemurian. According to Thusu (1978), Wille \& Gocht (1979) and Brenner (1986) Dapcodinium priscum does not range beyond the Hettangian, while Morbey (1978), Woollam \& Riding (1983), and Riding (1984) indicated a range of this species into the Early Sinemurian (see fig. 5). Dapcodinium priscum was recorded in the Gassum-1 borehole from samples dated as Early Sinemurian, based on ostracods and miospores (Dybkjær 1988, the range-chart).

Comparison with earlier recordings in the Danish region: Evitt (1961a) recorded Dapcodinium priscum from the Gassum-1 borehole in the core interval 1440m - $1434 m$ b.r.t. (dated as Early Sinemurian by Michelsen 1975, on the basis of ostracods). According to Dybkjær (1988), Dapcodinium priscum occurs, without Rhaetogonyaulax rhaetica, from $1534 \mathrm{~m}$ to $1420 \mathrm{~m}$ b.r.t. in Gassum-1 (samples Ga-3 to Ga-26), an interval that was referred to uppermost Rhaetian to Early Sinemurian on the basis of palynomorphs and ostracods (Dybkjær 1988).

Bertelsen (1979) recorded "cf. Dapcodinium" in Hobro-1, in samples dated as Early Jurassic. Lund (1977) recorded "cf. Dapcodinium" in the Rødby-1 borehole from two samples dated as Late Rhaetian (Upper Rhaetic sensu germanico) and Hettangian, respectively.

\section{The Liasidium variabile Zone}

Occurrence: In Fjerritslev-2, in samples $\mathrm{Fj}-5, \mathrm{c}$ to Fj-13,s (2105m-2038m b.r.t.), and in Stenlille-2, samples St-1,s to St-2,s (1359m-1341m b.r.t.).

Reference section: The Fjerritslev-2 borehole, 2105m-2038m b.r.t. (samples Fj-5,c to Fj-13,s).

Base: At the first appearance of Liasidium variabile. According to Woollam and Riding (1983), there is an interval (their Subzone B of the Dapcodinium priscum Zone (fig. 6)) between the last occurrence of Dapcodinium priscum and the first, appearance of Liasidium variabile where no dinoflagellate cyst species are recorded. Riding (1984), however, extended the range of Dapcodinium priscum to cover all of the Early Sinemurian, and Subzone B was thus no longer recognized. No such barren interval was recognized in the core samples from the Fjerritslev-2 borehole, but in the Gassum-1 borehole the interval covering the sequence from $1401 \mathrm{~m}$ to $1376 \mathrm{~m}$ b.r.t. (samples GA-29 to GA-33) 
could correspond to Subzone B of Woollam \& Riding (1983) (Dybkjær 1988, the range-chart).

Top: At the last occurrence of Liasidium variabile.

Characteristics: This zone is characterized by the presence of Liasidium variabile. Other dinoflagellate cyst species occur only sporadically.

Suggested age: Sinemurian. According to Thusu (1978) and Morbey (1978), Liasidium variabile ranges throughout the Sinemurian. According to Warrington (1981), Woollam \& Riding (1983), and Riding (1984), the range is restricted to the Late Sinemurian. Brenner (1986), however, recorded this species from samples referred to the uppermost Hettangian (fig. 5). In the Gassum-1 borehole Liasidium variabile was recorded some distance above the Hettangian-Sinemurian boundary (determined by ostracods and miospores) (Dybkjær 1988).

Comparison with earlier recordings in the Danish region: In sample GA-36 (1373m b.r.t.), in the Gassum-1 borehole, Liasidium variabile was recorded in large numbers (Dybkjær 1988).

\section{The Nannoceratopsis gracilis Zone}

Occurrence: In Fjerritslev-2, samples Fj-15,c and Fj-16,c (1561m-1329m b.r.t.), in Frederikshavn-2, samples Frh-15,c to Frh-22,s (789m-772m b.r.t.), and in Stenlille-2, samples St-11,w to St-16,w (1258m-1228m b.r.t.).

Reference section: The Frederikshavn-2 borehole 789 m-772m b.r.t. (samples Frh-15,c to Frh-22,s).

Base: At the first appearance of Nannoceratopsis gracilis, and/or Nannoceratopsis cf. senex.

In the Fjerritslev-2 borehole there is an interval between this zone and the Liasidium variabile Zone below, comprising samples $\mathrm{Fj}-7, \mathrm{c}$ to $\mathrm{Fj}-12$,c where no dinoflagellate cyst species were recorded. This interval probably corresponds to Subzone B of the Liasidium variabile Zone, proposed by Woollam \& Riding (1983) (fig. 6).

Top: No definite upper boundary was recognized in this study. Above the Nannoceratopsis gracilis Superzone, Woollam \& Riding (1983) recorded the incoming of widespread ctenidodinioid dinocysts. The incoming of this group could be used to define this boundary.

Characteristics: The presence of Nannoceratopsis gracilis, and/or Nannoceratopsis cf. senex. An additional dinoflagellate cyst species, Dinocyst sp. 1, was recorded from this zone, often in large numbers.

Age: Late Pliensbachian to ?Bajocian/Bathonian. According to several earlier investigations, Nannocera- topsis gracilis has its first appearance close to the EarlyLate Pliensbachian boundary (Evitt 1961b, Schulz \& Mai 1966, Wille \& Gocht 1979, Warrington 1981, Woollam \& Riding 1983), although Morbey (1978) indicated that the species also occurs sporadically in the Early Pliensbachian (fig. 5).

Nannoceratopsis gracilis has not been recorded above the Bathonian/Callovian boundary (Schulz \& Mai 1966, Thusu 1978, Woollam \& Riding 1983). Furthermore, according to Woollam and Riding (1983), the widespread record of ctenidodinioid dinocysts begins at the Bajocian/Bathonian boundary. This event was not recorded here.

Comparison with earlier recordings in the Danish region: Specimens referred to Nannoceratopsis gracilis have been recorded from the Gassum- 1 borehole, from samples dated as Late Pliensbachian on the basis of ammonites and ostracods (Evitt 1961b, Dybkjær 1988).

Bertelsen (1979) recorded Nannoceratopsis gracilis in two samples from the Hobro- 1 borehole. The species was recorded to occur commonly in a sample assigned a Late Pliensbachian age, and more sporadically in a sample assigned a Toarcian age on the basis of palynomorphs and ostracods.

\section{Stratigraphic conclusions}

The general palynomorph assemblages from each borehole are discussed below, on the basis of the proposed spore/pollen zonation and dinoflagellate cyst zonation. The chronostratigraphical subdivision of each borehole will also be presented.

\section{LEGEND (for flgs.7-10):}

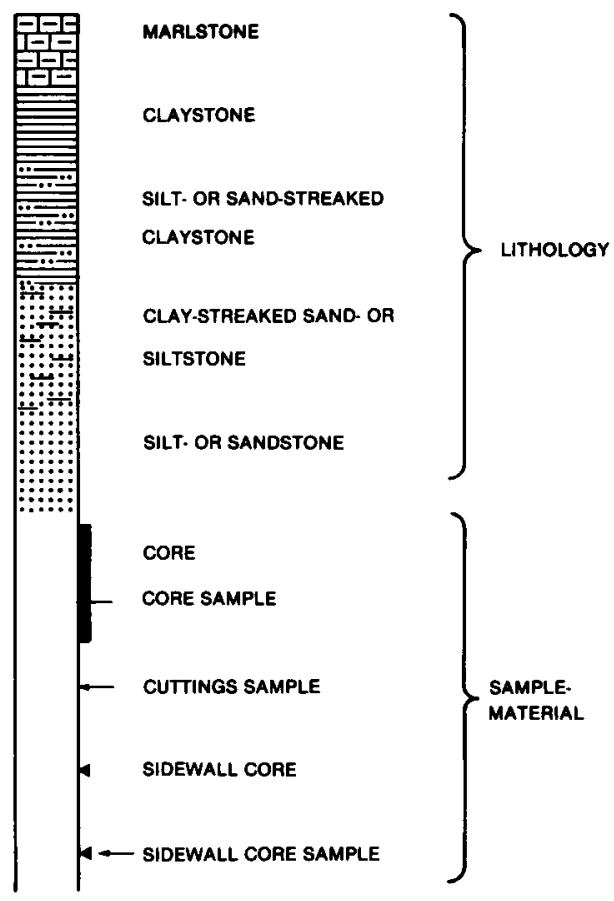


THE FJERRITSLEV NO. 2 BOREHOLE

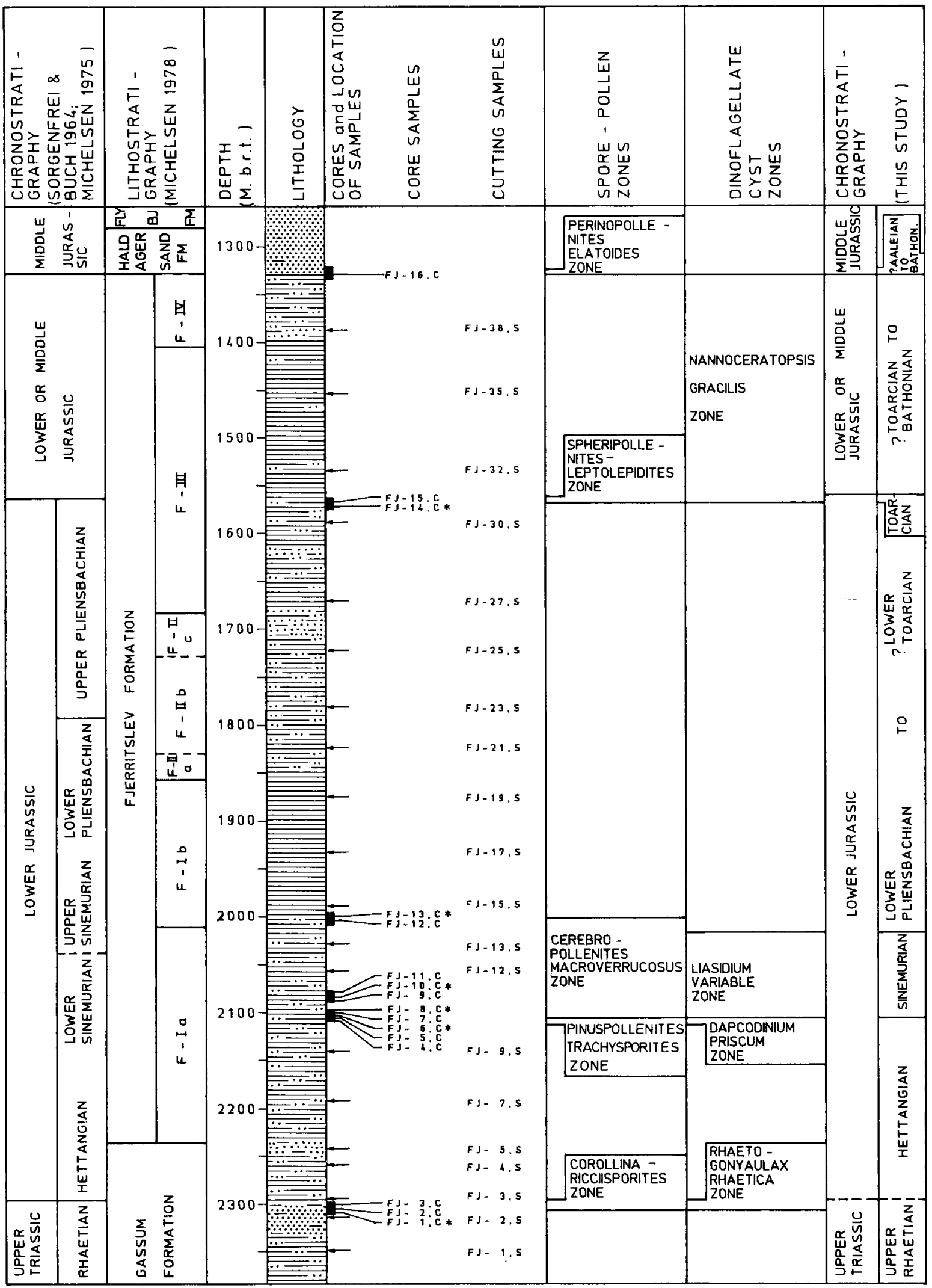

Fig. 7. The Lower Jurassic sequence of the Fjerritslev-2 borehole, showing the distribution of samples, palynological zones, and chronostratigraphy. Samples only used for the palynofacies investigation are marked by an asterisk.

A few core samples that could not be referred to any of the proposed zones are treated seperately as "unnamed intervals", and their ages are discussed.

The palynological zonations and stratigraphical con- clusions for each borehole are shown in figs 7-10. In these figures, the zones are only indicated where they have been recorded with certainty. The indicated lower boundary of each zone is based on data from core 
samples, while the upper boundary is based on data from either core samples or last-occurrences in cuttings samples.

\section{Fjerritslev-2}

Only a few, short cores were taken from the Jurassic sequence in this borehole (Fig. 7). It is not possible to deduce whether or not caving has contributed to the cuttings samples from this borehole. Thus only last occurrences have been used as stratigraphical markers from the cuttings samples.

Spore/pollen zonation:

The Corollina - Ricciisporites Zone:

Samples Fj-2,c and Fj-3,c (2304m-2303m b.r.t.).

This zone is very well developed in the Fjerritslev-2 borehole. Corollina torosus clearly dominates the palynoflora assemblage ( $42 \%$ and $35 \%$ respectively), while Ricciisporites tuberculatus occurs commonly (about $4 \%$ and $11 \%$ respectively). Several, mainly Rhaetian, species occur sporadically to commonly: Cf. Taneaesporites, Zebrasporites laevigatus, Zebrasporites interscriptus, Densosporites fissus, Triancoraesporites ancorae, and Polypodiisporites polymicroforatus.

Stratigraphically useful last-occurrences:

In the cuttings sample Fj-3,s (2294m b.r.t.) the species Ricciisporites tuberculatus, Zebrasporites interscriptus, and Polypodiisporites polymicroforatus all have their last occurrences, indicating an age not younger than earliest Hettangian for this level.

The Pinuspollenites - Trachysporites Zone:

Sample Fj-4,c (2106m b.r.t.).

This sample is not typical of the Pinuspollenites - Trachysporites Zone. Pinuspollenites minimus only constitutes about $5 \%$ of the spore/pollen assemblage, and Deltoidospora toralis only $8 \%$. With these exceptions, the general assemblage corresponds well with the $P i$ nuspollenites - Trachysporites Zone. None of the mainly Rhaetian species known from the Corollina Ricciisporites Zone were recorded, and no Cerebropollenites macroverrucosus were observed.

The Cerebropollenites macroverrucosus Zone: Samples Fj-5,c to Fj-12,c (2105m-2003m b.r.t.). Cerebropollenites macroverrucosus was only recorded sporadically in the samples composing this zone. Perinopollenites elatoides dominates the assemblage, together with Pinuspollenites minimus and Deltoidospora toralis, while Corollina torosus is reduced in abundance compared to the preceding zone, and only occurs commonly in this interval. A number of species appear for the first time in the lowermost sample in this zone, including Protopinus scanicus, Schismatosporites ova- lis, Cerebropollenites thiergartil, Camarozonosporites rudis, Stereisporites cicatricosus, Uvaesporites argenteaeformis and three species of the genus Chasmatosporites.

The Spheripollenites - Leptolepidites Zone:

Sample Fj-15,c (1561m b.r.t.).

The palynomorph assemblage in this sample is clearly dominated by Corollina torosus, while Spheripollenites psilatus constitutes $13 \%$. The stratigraphically important species Leptolepidites major, and Tripartina variabilis appear in this sample.

As mentioned earlier, the maximum of Spheripollenites in the Early Toarcian coincides with a maximum of Corollina, and a minimum of bisaccate pollen (Lund \& Pedersen 1985). In sample $\mathrm{Fj}-15$, c, Corollina torosus constitutes about $36 \%$ of the total spore/pollen assemblage, showing a distinct increase from $9 \%$ in the previous sample $(\mathrm{Fj}-12, \mathrm{c})$, whilst the bisaccate pollen shows a decrease from about $34 \%$ to $17 \%$.

The Perinopollenites elatoides Zone:

Sample Fj-16,c (1329m b.r.t.).

The species Perinopollenites elatoides forms about $26 \%$ of the terrestrial palynomorphs in this sample, while Corollina torosus only constitutes about $5 \%$.

\section{Dinoflagellate cyst zonation:}

The Rhaetogonyaulax rhaetica Zone:

Samples Fj-2,c and Fj-3,c (2304m-2303m b.r.t.).

Rhaetogonyaulax rhaetica was recorded in low numbers in both samples, while Dapcodinium priscum is common to frequent.

The Dapcodinium priscum Zone:

Sample Fj-4,c (2106m b.r.t.).

A single specimen of Dapcodinium priscum was recorded from this sample.

The Liasidium variabile Zone:

Samples Fj-5,c (2105m b.r.t.) to Fj-13,s (2038m b.r.t.). Only a single specimen was recorded in sample Fj-5,c during counting, but several specimens were observed whilst scanning the slide. Liasidium variabile was recorded in large numbers in the cuttings samples Fj-12,s and $\mathrm{Fj}-13$,s.

Unnamed interval:

Sample Fj-12,c (2003m b.r.t.). This sample shows none of the dinoflagellate cyst species used for zonation, and is thus not referred to any dinoflagellate cyst zone.

The Nannoceratopsis gracilis Zone:

Samples Fj-15,c and Fj-16,c (1561m-1329m b.r.t.).

Nannoceratopsis gracilis was recorded commonly in sample Fj-15,c whereas Nannoceratopsis cf. senex and Nannoceratopsis cf. pellucida were recorded sporad- 
ically. Only a few specimens of Nannoceratopsis gracilis were recorded in sample $\mathrm{Fj}-16, \mathrm{c}$.

The chronostratigraphical subdivision of the Fjerritslev-2 sequence is thus suggested to be as follows (see also fig. 7):

$\begin{array}{ll}1329 m \text { b.r.t. }(\mathrm{Fj}-16, \mathrm{c}) \quad & \text { Middle Jurassic } \\ & \text { ?Aalenian - Bathonian) }\end{array}$

$1561 \mathrm{~m}$ b.r.t. $(\mathrm{Fj}-15, \mathrm{c}) \quad$ Toarcian

$2038 \mathrm{~m}-2105 \mathrm{~m}$ b.r.t. Sinemurian (Fj-13,s to $\mathrm{Fj}-5, \mathrm{c})$

$2106 \mathrm{~m}(\mathrm{Fj}-4, \mathrm{c})$

Hettangian

$2294 \mathrm{~m}(\mathrm{Fj}-3, \mathrm{~s})$

$2303 \mathrm{~m}-2348 \mathrm{~m}$ b.r.t. (Fj-3,c to $\mathrm{Fj}-1, \mathrm{~s})$

uppermost Rhaetian lowermost Hettangian

Upper Rhaetian

\section{Frederikshavn-2}

The cored intervals from this borehole are sparse (Fig. 8). Furthermore, several of the cuttings samples are seriously contaminated by material referable to the Barremian or Aptian (Early Cretaceous) (see discussion on p. 16-17). These factors in combination precluded detailed palynostratigraphy and dating. In addition, the palynomorph assemblage in this borehole generally shows less distinct stratigraphical changes than in the other investigated sequences (see the range-charts, enclosures 3 and 4).

\section{Spore/pollen zonation:}

The Corollina - Ricciisporites Zone:

Sample Frh-1,c (930m b.r.t.).

This zone is not well developed in Frederikshavn-2. Ricciisporites tuberculatus only occurs sporadically, and Corollina torosus is not as dominant as in the other boreholes (constituting $16 \%$ of the terrestrial palynomorphs). The species Deltoidospora toralis, and Perinopollenites elatoides occur frequently $(11 \%$ and $10 \%$ respectively), whereas the mainly Rhaetian species $\mathrm{Po}$ lypodiisporites ipsviciensis occurs sporadically. The terrestrial palynomorph assemblage in this sample is composed of roughly equal amounts of spores and nonsaccate pollen ( $43 \%$ and $44 \%$ respectively), while the saccate pollen only constitutes $13 \%$.

Stratigraphically useful last-occurrence:

In sample Frh-5,s ( $897 \mathrm{~m}$ b.r.t.) Zebrasporites interscriptus has its last appearance, indicating an age not younger than Early Sinemurian.
The Pinuspollenites - Trachysporites Zone:

This zone was not recorded in Frederikshavn-2.

The Cerebropollenites macroverrucosus Zone:

Samples Frh-2,c to Frh-14,c (892m-851m b.r.t.).

Cerebropollenites macroverrucosus was recorded sporadically in this interval. Lycopodiumsporites semimuris appears at the base of this zone. The freshwater algae Botryococcus was sporadically to commonly recorded throughout the zone.

Stratigraphically useful last-occurrence:

Camarozonosporites rudis has its last appearance in sample Frh 11,s (862m b.r.t.), indicating an age not younger than Hettangian. This does not agree with the presence of Cerebropollenites macroverrucosus from Frh-2,c ( $892 \mathrm{~m}$ b.r.t.), which indicates an age not older than Early Sinemurian. The Camarozonosporites rudis forms could be reworked.

Unnamed interval:

Sample Frh-15,c ( $789 \mathrm{~m}$ b.r.t.). This sample is characterized by a dominance of Perinopollenites elatoides, Pinuspollenites minimus, and Chasmatosporites hians. Furthermore the stratigraphically important species Staplinisporites telatus and Manumia delcourtii were both recorded from this sample. In contrary to the samples above, relatively few Corollina torosus and many saccate pollen were recorded. No specimens referred to either Leptolepidites or Ischyosporites were recorded from this sample. Non-saccate pollen dominates the terrestrial palynomorphs, constituting $49 \%$, while saccate pollen constitutes $21 \%$, and spores $30 \%$.

The first appearance of Staplinisporites telatus and Manumia delcourtii together indicate a Toarcian age for this sample (Schulz \& Mai 1966, Schulz 1967, Herngren $\&$ de Boer 1974, Morbey 1978) (fig. 4).

The Spheripollenites - Leptolepidites Zone:

Samples Frh-17,c to Frh-22,c (787m-782m b.r.t.).

The abundance of Spheripollenites in these samples is very low compared to the other boreholes, but the first appearance of both Leptolepidites major and Ischyosporites variegatus in sample Frh $17, \mathrm{c}$, and the coincident distinct increase in Corollina torosus (from $8 \%$ in sample Frh-15,c to $23 \%$ in Frh-17,c), and decrease of the saccate pollen (from $21 \%$ in sample Frh-15,c, to $13 \%$ in Frh $17, \mathrm{c}$ ), refers this level to the Spheripollenites - Leptolepidites Zone. Spheripollenites psilatus was only commonly recorded from the two youngest samples in this zone. The stratigraphically important species Manumia delcourtii was recorded sporadically.

The Perinopollenites elatoides Zone:

This was not recorded in Frederikshavn-2. 
THE FREDERIKSHAVN NO. 2 BOREHOLE

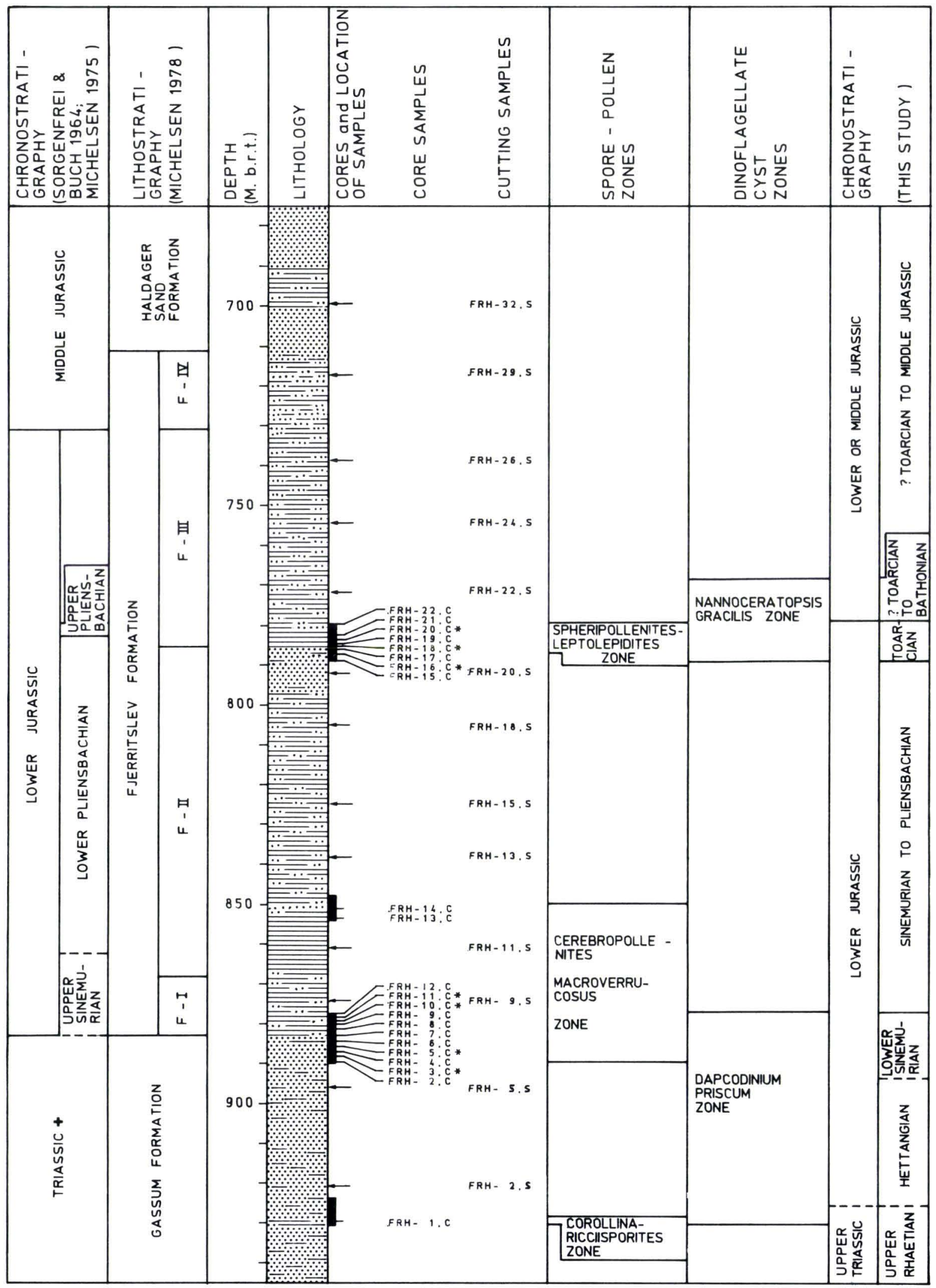

Fig. 8. The Lower Jurassic sequence of the Frederikshavn-2 borehole, showing the distribution of samples, palynological zones, and chronostratigraphy. Legend: see text to fig. 7.

+: This complete sequence was previously referred erroneously to the Triassic (Michelsen, 1975, text-fig. 3). The Triassic- Jurassic boundary probably occurs somewhere within the sequence referred to the Gassum Formation (pers. comm., Michelsen, 1989). 
Dinoflagellate cyst zonation:

The Rhaetogonyaulax rhaetica Zone:

This was not recorded from this borehole.

The Dapcodinium priscum Zone:

Samples Frh-1,c to Frh-12,c (930m-880m b.r.t.).

Dapcodinium priscum was only recorded sporadically in the lower part of the zone, but was more common in sample Frh-12,c.

Unnamed interval:

Samples Frh-13,c and Frh-14,c (854m-851m b.r.t.). As the samples Frh-13,c and Frh-14,c contain none of the dinoflagellate cyst species that define the zones, they are not referred to any dinoflagellate cyst zones.

The Liasidium variabile Zone:

This was not recorded in this borehole.

The Nannoceratopsis gracilis Zone:

Samples Frh-15,c to Frh-22,s (789m-772m b.r.t.).

Nannoceratopsis gracilis was recorded commonly to frequently throughout this interval, and Nannoceratopsis cf. senex was recorded from sample Frh-22,c.

The following chronostratigraphical subdivision of the sequence from the Frederikshavn-2 borehole is suggested:

$772 \mathrm{~m}$ b.r.t. (Frh-22,s) ?Toarcian to Bathonian

$782 \mathrm{~m}-789 \mathrm{~m}$ b.r.t.

Toarcian

(Frh-22,c to Frh-15,c)

$880 \mathrm{~m}-892 \mathrm{~m}$ b.r.t.

lowermost Sinemurian

(Frh-12,c to Frh-2,c)

930m b.r.t. (Frh-1,c)

transitional Rhaetian -

Hettangian

\section{Stenlille-2}

This borehole was intensively cored in the lower and upper part of the investigated sequence, but the middle part is only represented by cuttings samples (see fig. 9). It is presumed that caving is responsible for the palynomorph assemblage in sample St-5,s (see the rangecharts, tables 5 and 6 ). The caved material is thought to come from a level close to sample St-15,w, as the palynomorph assemblage in St-5,s correlates very well with this sample. Other distinct signs of caving were not recorded in the cuttings samples from this borehole.

Spore-pollen zonation:

The Corollina - Ricciisporites Zone:

Sample St-1,c to St-3,c (1513m-1510m b.r.t.).

The lowermost sample in this borehole (sample St-1,c, $1513 \mathrm{~m}$ b.r.t.) yielded a very distinct palynomorph assemblage, overwhelmingly dominated by Ricciisporites tuberculatus $(92 \%)$. Only a few other species were recorded from this level, including Densosporites fissus, Calamospora tener, Corollina torosus, and Deltoidospora toralis. None of the mainly Early Rhaetian species Rhaetipollis germanicus, Granuloperculatipollis rudis, and Ovalipollis ovalis, and none of the mainly Late Rhaetian species characterizing the Corollina - Ricciisporites Zone were recorded from this sample. The dominance of Ricciisporites tuberculatus is therefore thought to be a function of facies dependency, and the sample St-1,c should possibly be seen as belonging to the Corollina - Ricciisporites Zone.

Samples St-2,c, and St-3,c (1512m to $1510 \mathrm{~m}$ b.r.t.) yielded a palynoflora assemblage most typical of the Corollina - Ricciisporites Zone, with a marked dominance of Corollina torosus (39\% and $21 \%$ respectively), and with common occurrences of Ricciisporites tuberculatus (6-7\%), and several mainly Rhaetian spore/pollen species: Densosporites cavernatus, Ovalipollis ovalis, Cingulizonates rhaeticus, Camarazonosporites rudis, Aratrisporites fimbriatus, Semiretisporis goetae, Triancoraesporites reticulatus, Limbosporites lundbladii, Zebrasporites interscriptus, Perinosporites thuringiacus, Triancoraesporites ancorae, and Polypodiisporites polymicroforatus. The freshwater algae $B o$ tryococcus occurs commonly.

Unnamed interval:

Sample St-5,c (1496m b.r.t.). In this sample, a palynomorph assemblage was recorded that could not be referred to any of the proposed zones. The assemblage is dominated by Deltoidospora toralis (constituting about $17 \%$ of the spore/pollen assemblage), and by Calamospora tener (constituting about 14\%). Corollina torosus only constitutes a minor part (about $3 \%$ ) of this assemblage. None of the mainly Rhaetian species that were recorded from the zone below, were recorded from this sample, except for sporadic occurrences of Ricciisporites tuberculatus $(<1 \%)$. The species Perinopollenites elatoides, Marattisporites scabratus, and Punctatisporites globosus occur frequently, while Trachysporites fuscus, Trachysporites sparsus, Punctatisporites major and species of the genus Stereisporites are common. Spores overwhelmingly dominate this assemblage, constituting $82 \%$ of the spore/pollen assemblage.

This assemblage can be tentatively assigned a basal Hettangian age. As Ricciisporites tuberculatus is the only representative of the Rhaetian species, the assemblage is presumably slightly younger than the "topmost Upper Rhaetic?" assemblage from the Rødby-1 borehole (Lund 1977) (see discussion concerning the Corollina-Ricciisporites Zone, p. 37, this study). The dominance of Deltoidospora toralis and the common occurrence of Trachysporites fuscus points towards a Hettangian age. The sporadic occurrence of Pinuspollenites minimus is probably facies controlled. 
the Stenlille No. 2 BOREhOle

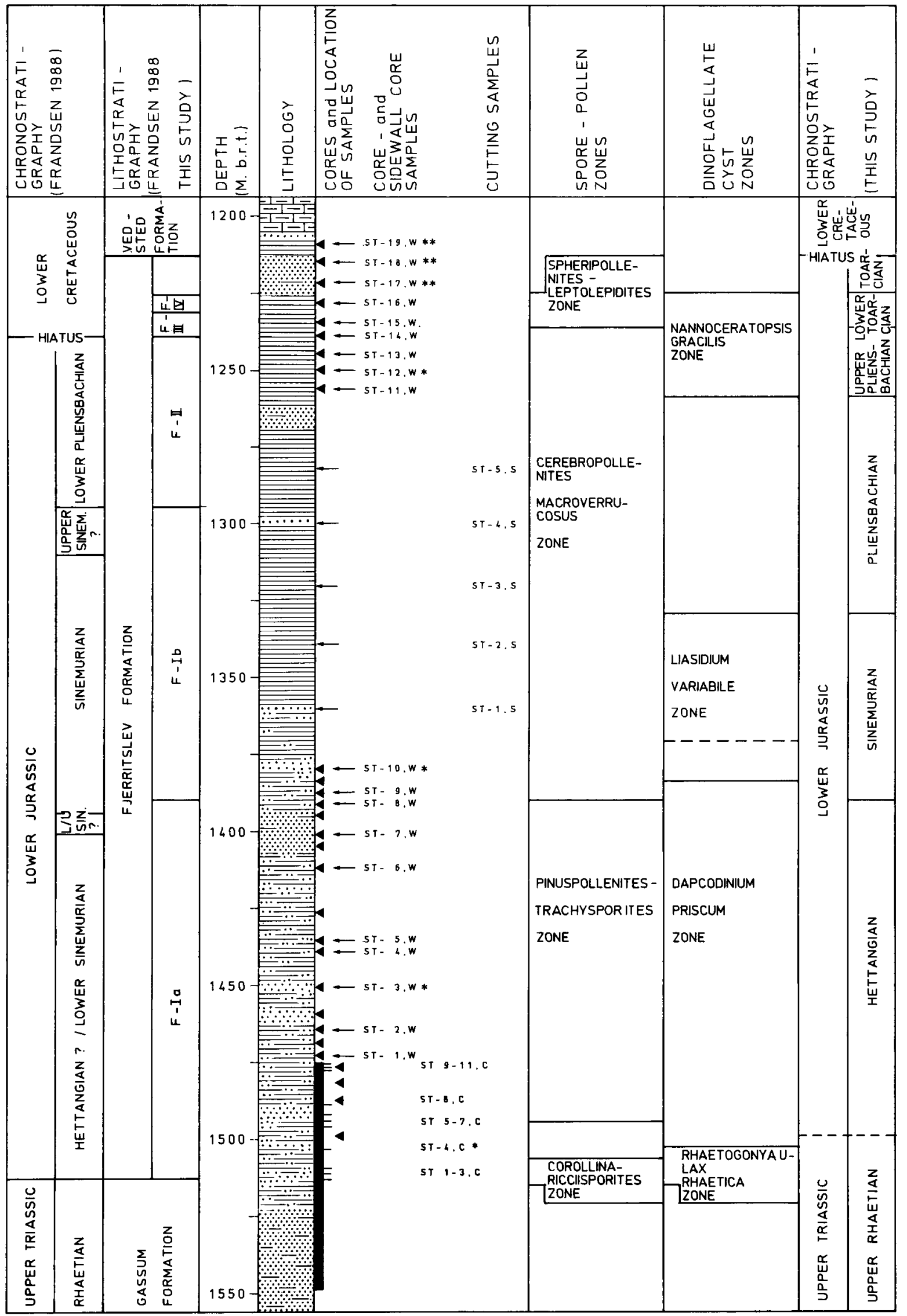

Fig. 9. The Lower Jurassic sequence of the Stenlille-2 borehole, showing the distribution of samples, palynological zones, and chronostratigraphy. Legend: see text to fig. 7.

The indicated presence of F-III and F-IV Member in this borehole is a proposal, based on biostratigraphic-and palynofacies correlations from this study (see discussion on p. 52). 
The general assemblage, the high abundance of $\mathrm{Del}$ toidospora toralis, and the low abundances of Corollina torosus and Pinuspollenites minimus correspond very well with the upper part of the Late Rhaetian Zone A (Dybkjær 1988), with the exception of the absence of the Rhaetian types recorded in Zone A.

The Pinuspollenites - Trachysporites Zone:

Samples St-6,c to St-8,w (1494m-1392m b.r.t.)

This zone is very well developed in Stenlille-2. Deltoidospora toralis clearly dominates the assemblage (with a relative abundance between $14 \%$ and $32 \%$ ). $\mathrm{Pi}$ nuspollenites minimus is relatively abundant at the base of this zone, (12-19\% in samples St-6,c to St-1,w), decreasing towards the top. The mainly Rhaetian species, Zebrasporites interscriptus and Ricciisporites tuberculatus, occur sporadically in the lower part of the zone. Botryococcus occurs sporadically.

The Cerebropollenites macroverrucosus Zone: Samples St-9,w to St-14,w (1390m-1320m b.r.t.). Cerebropollenites macroverrucosus occurs sporadically to commonly throughout this interval. The species $\mathrm{Del}$ toidospora toralis decreases in abundance upwards, whereas Pinuspollenites minimus shows a distinct increase in abundance upwards in the zone. The species Lycopodiumsporites semimuris has its first appearance in sample St- 8 ,w ( $1392 \mathrm{~m}$ b.r.t.), immediately below the base of this zone.

\section{The Spheripollenites - Leptolepidites Zone:} Samples St-15,w, and St-16,w (1234m-1228m b.r.t.). The genus Spheripollenites psilatus is overwhelmingly dominant in these samples, constituting about $99 \%$ of St $-15, w$ and about $68 \%$ of St-16,w; this is clearly a reflection of the Early Toarcian anoxic event (see discussion on p. 64). Sample St-16,w shows the characteristic features of the zone i.e. the high relative abundance of Corollina torsosus and the paucity of saccate pollen. Corollina torosus, Deltoidospora toralis, and Intrapunctisporis toralis occur sporadically in sample St-15,w. Three species of Leptolepidites were recorded in sample St-16,w, together with Striatella spp. in atypically high abundance; this sample also included Manumia delcourtii and Tripartina variabilis.

The Perinopollenites elatoides Zone:

This zone was not recorded in Stenlille-2.

Dinoflagellate cyst zonation:

The Rhaetogonyaulax rhaetica Zone:

Samples St-1,c to St-3,c (1513m-1510m b.r.t.).

Sample St-1,c is referred to the Rhaetogonyaulax rhaetica Zone on the basis of frequent records of Dapcodinium priscum from all three samples, combined with the occurrence of Rhaetogonyaulax rhaetica in the two upper samples. Rhaetogonyaulax rhaetica was ob- served frequently in sample St-2,c, whereas only a single specimen was recorded from St-3,c.

The Dapcodinium priscum Zone:

Samples St-5,c to St-9,w (1496m-1390m b.r.t.).

Dapcodinium priscum occurs regularly in all samples in this zone. Tasmanites occurs sporadically, and Leiofusa jurassica occurs frequently in sample St-8,c.

The Liasidium variabile Zone:

Samples St-1,s to St-2,s (1359m-1341m b.r.t.).

The location of the lower boundary of this zone is questionable, as Liasidium variabile was only recorded from cuttings samples.

The Nannoceratopsis gracilis Zone:

Samples St-11,w to St-16,w (1258m-1228m b.r.t.).

Nannoceratopsis gracilis was recorded sporadically to commonly from all samples in this zone. In addition Dinocyst sp. 1 was recorded from sample St-11,w, Nannoceratopsis sp.1 from sample St-14,w, and Nannoceratopsis cf. senex from samples $\mathrm{St}-15, \mathrm{w}$, and $\mathrm{St}-16, \mathrm{w}$.

Qualitative biostratigraphical examination of the uppermost sidewall cores from the Stenlille-2 borehole, St-17,w (1222m b.r.t.), St-18,w (1216m b.r.t.), and St-19,w (1210m b.r.t.) was carried out to clarify the location of the lower boundary of the Cretaceous and the age of the samples immediately below the Cretaceous.

The palynomorph assemblages recorded from samples St-17,w and St-18,w indicated a Toarcian age. These samples showed common occurrences of specimens referable to the genera Ischyosporites, Leptolepidites and Manumia, indicating a Toarcian to Middle Jurassic age. The species Taurocusporites verrucatus Schulz 1967 and Polycingulatisporites liassicus Schulz 1967 were also recorded. These two species both occur sporadically from the Norian to the lowermost Toarcian (Lias epsilon 1) and commonly in the upper part of the Early Toarcian and the lower part of the Late Toarcian (in Lias epsilon 2 to Lias zeta 2) in East Germany (Schulz \& Mai 1966, Schulz 1967). Neither of these two species were recorded above the Toarcian in East Germany (Schulz \& Mai 1966). No specimens indicative of an Early Cretaceous age were recorded from these samples.

The palynomorph assemblage recorded from sample St-19,w was overwhelmingly dominated by dinoflagellate cyst species indicating an Early Cretaceous age (e.g. Pseudoceratium pelliferum Gocht 1957, Oligosphaeridium complex (White 1842) Davey \& Williams 1966, and Kleithriasphaeridium corrugatum Davey 1974. (See the range of these species in HeilmannClausen, 1987).

The lower boundary of the Cretaceous should thus be placed between samples St-18,w (1216m b.r.t.) and St-19,w (1210m b.r.t.). It is probably located at $1215 \mathrm{~m}$ b.r.t., at the top of the sandstone sequence. This 
boundary represents an extensive hiatus, probably comprising the Middle and Late Jurassic.

Deposits of uppermost Early Jurassic age have not been recorded from the nearby Slagelse- 1 borehole, possibly due to uplift of the Ringkøbing-Fyn High during the Mid Kimmerian Tectonic Phase.

The chronostratigraphical subdivision of the sequence investigated from the Stenlille-2 borehole is thus suggested to be as follows:

$1210 \mathrm{~m}$ b.r.t. $(\mathrm{St}-19, \mathrm{w})$

Lower Cretaceous

Hiatus

$1216 \mathrm{~m}-1222 \mathrm{~m}$ b.r.t.

(St-18,w to St-17,w)

Toarcian

$1228 \mathrm{~m}-1234 \mathrm{~m}$ b.r.t.

(St-16,w to St-15,w)

$1240 \mathrm{~m}-1258 \mathrm{~m}$ b.r.t.

(St-14,w to St-11,w)

$1341 \mathrm{~m}-1390 \mathrm{~m}$ b.r.t.

(St-2,s to St-9,w)

$1392 \mathrm{~m}-1494 \mathrm{~m}$ b.r.t.

(St-8,w to St-6,c)

$1496 \mathrm{~m}$ b.r.t. (St-5,c)

$1510 \mathrm{~m}$ to $1513 \mathrm{~m}$ b.r.t.

(St-3,c to St-1,c)

\section{Gassum-1}

A spore/pollen zonation and dating of the Jurassic sequence in the Gassum-1 borehole was presented by Dybkjær (1988). However, on the basis of the dinoflagellate cyst zonation, and the dating proposed here, it was possible to propose a more detailed chronostratigraphical subdivision of the Jurassic sequence in this borehole. The dinoflagellate cyst zonation and the resulting dating are shown in fig. 10. All the investigated samples were core samples.

The Rhaetogonyaulax rhaetica Zone:

This zone was not recorded in Gassum-1.

The Dapcodinium priscum Zone:

Samples GA-3 to GA-26 (1513m-1420m b.r.t.).

The Liasidium variabile Zone:

Sample GA-36 (1373m b.r.t.).

The Nannoceratopsis gracilis Zone:

Samples GA-49 to GA-60 (1303m-1210m)

The following chronostratigraphical subdivision is proposed from a combination of this dinoflagellate cyst zonation and the previous spore/pollen zonation of Dybkjær (1988):
$1144 \mathrm{~m}-1149 \mathrm{~m}$ b.r.t.

(GA-71 to GA-67)

$1173 \mathrm{~m}$ b.r.t. (GA-65)

Middle Volgian

Kimmeridgian to

Lower Volgian

Hiatus

$1210 \mathrm{~m}-1303 \mathrm{~m}$ b.r.t.

(GA-60 to GA-49)

$1305 \mathrm{~m}-1360 \mathrm{~m}$ b.r.t.

(GA-47 to GA-38)

Upper Pliensbachian

Pliensbachian

1373m-1404m b.r.t.

(GA-36 to GA-29)

Sinemurian

$1420 \mathrm{~m}-1439 \mathrm{~m}$ b.r.t.

(GA-26 to GA-20)

Lower Sinemurian

$1464 \mathrm{~m}-1513 \mathrm{~m}$ b.r.t.

(GA-18 to GA-4)

$1534 \mathrm{~m}-1536 \mathrm{~m}$ b.r.t.

(GA-3 to GA-1)

Hettangian

Upper Rhaetian

\section{Comparison with previous work}

\section{Fjerritslev-2}

The results of the present study correlate very well with the ostracod-stratigraphy presented by Michelsen (1975) (fig. 7), with the exception of the dating of the core $1561 \mathrm{~m}-1564 \mathrm{~m}$ b.r.t. According to Michelsen (1975), this core contains an ostracod fauna of Late Pliensbachian age, whereas the palynomorph assemblage indicates a Toarcian age.

\section{Frederikshavn-2}

The stratigraphical results of this study are broadly compatible with the ostracod-stratigraphy presented by Michelsen (1975) (fig. 8).

The core from $886 \mathrm{~m}$ to $880 \mathrm{~m}$ b.r.t. (samples Frh-8,c to Frh-12,c) is dated here as being of Early Sinemurian age on the basis of the presence of Dapcodinium priscum. The dating of this sequence as Late Sinemurian by Michelsen (1975) was based on the occurrence of the ostracod species Progonoidea aucuticostata which is only known from the Late Sinemurian.

There is also a difference in the dating of the cores from $789 \mathrm{~m}$ to $783 \mathrm{~m}$ b.r.t., and $783 \mathrm{~m}$ to $780 \mathrm{~m}$ b.r.t. (sample Frh-15,c to Frh-22,c). Michelsen (1975) assigned the first of these to the Early Pliensbachian, and the second to the Late Pliensbachian, while both sequences are dated as Toarcian in this study. 


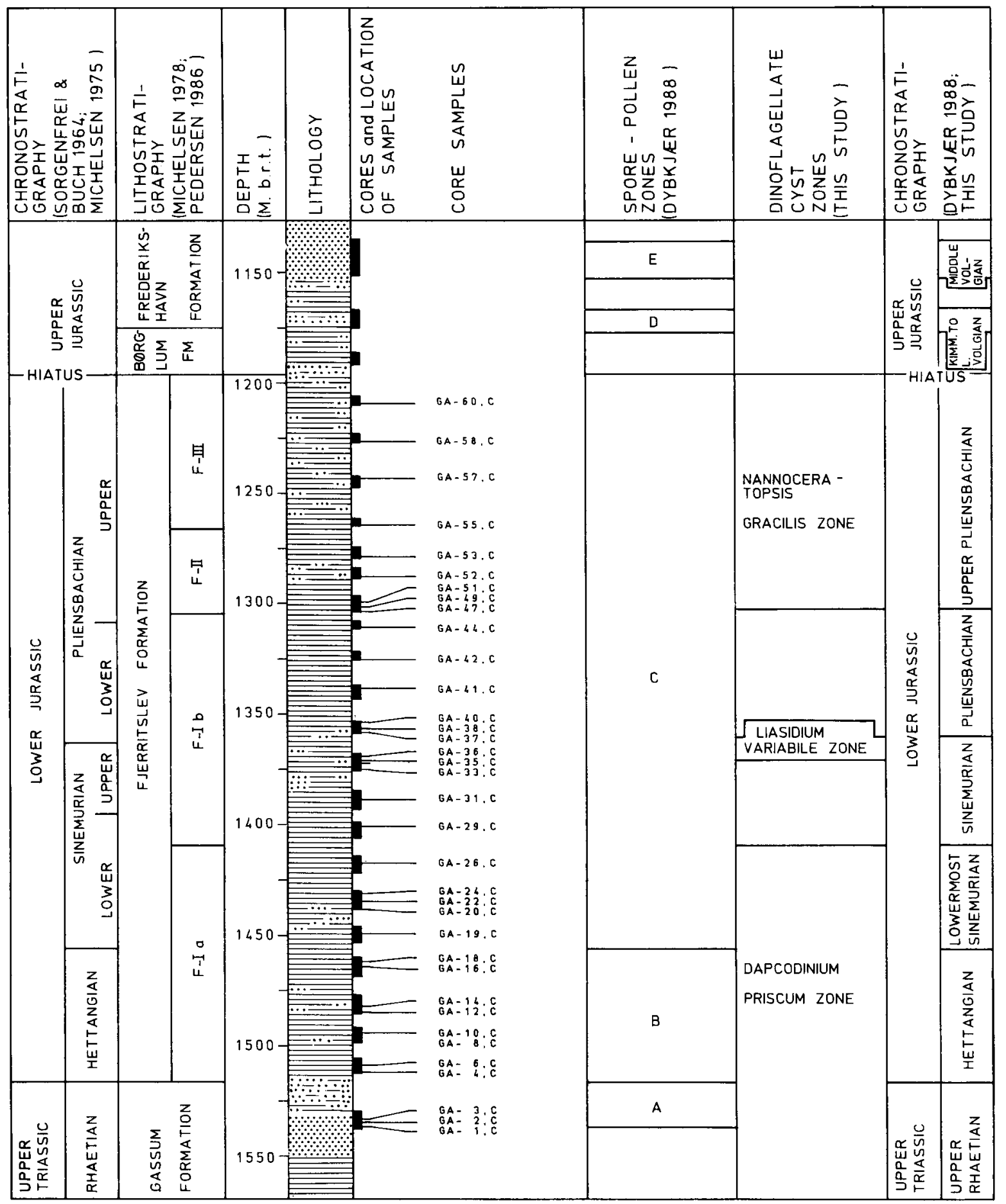

Fig. 10. The Lower Jurassic sequence of the Gassum-1 borehole, showing the distribution of samples, palynological zones, and chronostratigraphy. Legend: see text to fig. 7 .

These disagreements concerning the dating of the sequences from the Fjerritslev-2 and Frederikshavn-2 boreholes indicate that an integrated biostratigraphical study, comprising palynomorphs as well as ostracods and other fossil-groups (especially ammonites) is necessary to clarify these problems.

\section{Stenlille-2}

No previous biostratigraphical studies of the Stenlille-2 borehole have been published. The chronostratigraphical subdivision shown in fig. 9, from an unpublished report by Frandsen (1988), is based on preliminary results from ostracod- and palynostratigraphy in Stenlille-1 (Michelsen 1980, Hansen 1981), correlated to Stenlille- 2 by means of petrophysical logs.

This subdivision does not correlate very well with the stratigraphical results from the present study. The disagreements in the lower part of the sequence will not be discussed in detail, as the previous dating was only 
preliminary, but a major disagreement in the uppermost part of the investigated sequence will be discussed. The two sidewall core samples St-15,w and St 16 ,w (1234m and $1228 \mathrm{~m}$ b.r.t.) are, in this study, assigned an Early Toarcian age, while the earlier studies (of cuttings samples) in Stenlille-1 indicated a Late Jurassic/Early Cretaceous age for this level. This disagreement is probably due to caving in the cuttings samples from Stenlille-1, used in the earlier investigations. The brief palynological investigation of samples St-17,w to St-19,w (this study) revealed that a major hiatus, comprising the Middle and Late Jurassic, is located between samples St-18,w (1216m b.r.t.) and St-19,w (1210m b.r.t.).

\section{Gassum-1}

The chronostratigraphical subdivision of the Jurassic sequence in Gassum-1 presented by Dybkjær (1988) has been improved in the present study by using the dinoflagellate cyst zonation. The resulting, more detailed, chronostratigraphical subdivision of the sequence corresponds very well with the subdivision of Michelsen (1975), based on ostracods.

\section{Chronostratigraphic boundaries compared with lithostratigraphic units}

An overall picture of the lateral and vertical distribution of the resulting chronostratigraphical boundaries in relation to the lithostratigraphical subdivision of Michelsen (1978) is shown in fig. 11. The ages of the members of the Fjerritslev Formation according to Michelsen (1978, fig. 3) are mentioned on p. 10.

The suggested presence of the F-III and F-IV members in Stenlille-2 should be regarded solely as a proposal; it is NOT based on lithological evidence. A relationship with these lithological units is, however, strongly indicated by the kerogen assemblages recorded here, (see p. 64) and by the Toarcian age of the samples (St-15,w and St-16,w) representing this interval. The sandy sequence immediately below the hiatus in Stenlille-2, represented by sample St-17,w and St-18,w, was dated as Toarcian, but is not referred to any lithostratigraphic unit.

It is clear that the top of the Gassum Formation is diachronous, as also stated by Michelsen (1973, 1975, 1978). In the central and southern parts of the basin (e.g. in the Fjerritslev-2, Gassum-1 and Stenlille-2 boreholes) the sand-rich Gassum Formation was succeeded by mud-dominated deposits of the Fjerritslev Formation during topmost Rhaetian to Early Hettangian times, whereas, according to this study, this depositional shift did not occur in the northeastern parts of the basin, e.g. in the Frederikshavn-2 borehole, before the earliest Sinemurian. According to Michelsen (1975), the overstepping in the northeastern parts did not take place until the Late Sinemurian.

The transition from F-Ia member to F-Ib member is dated as Sinemurian in the Gassum-1 and Stenlille-2 boreholes. In Fjerritslev-2, this transition is dated as Sinemurian or at the Sinemurian-Pliensbachian boundary. In Frederikshavn-2 the "old" F-I member (as defined by Michelsen 1978) has not been subdivided. According to Michelsen (1978, fig. 3) the F-Ia member is of Hettangian to Early Sinemurian age, whereas the F-Ib member is of Late Sinemurian to earliest Early Pliensbachian age.

The boundary between the F-Ib member (or the "old" F-I member in Frederikshavn-2) and the F-II member occurs within the Sinemurian or Pliensbachian in all four boreholes. It was not possible to date this event more precisely on the basis of palynological evidence.

The boundary between the F-II member and the F-III member occurs within the Pliensbachian in the Gassum-1 borehole. In Stenlille-2 and Frederikshavn-2, this contact occurs at the Pliensbachian-Toarcian boundary, or (in the latter borehole) within the Toarcian. In Fjerritslev-2, this boundary can not be dated more accurately than Pliensbachian or Toarcian. According to Michelsen (1978, fig. 3), the F-II member is of Early to middle Late Pliensbachian age, and the F-III member of middle Late Pliensbachian to Toarcian age.

In the Stenlille- 2 borehole, the transition from the interval here referred to the F-III member to the interval referred to the F-IV member occurs within the Toarcian. In Fjerritslev-2 and Frederikshavn-2, this boundary cannot be dated more accurately than Toarcian to Middle Jurassic. The F-IV member is missing in the Gassum-1 borehole.

The boundary between the Fjerritslev Formation and the overlying Haldager Sand Formation is dated as Middle Jurassic in the Fjerritslev-2 borehole, and as Middle Jurassic, possibly transitional Toarcian-Middle Jurassic in Frederikshavn-2. Due to the major hiatus in the Gassum-1 borehole, the sequence succeeding the Fjerritslev Formation in this borehole is of Late Jurassic age. The uppermost part of the Fjerritslev Formation is here of Late Pliensbachian age. The upper boundary of the Fjerritslev Formation has not been defined in Stenlille-2. The beds immediately below the hiatus have been assigned a Toarcian age. 


\section{FREDERIKS- HAVN - 2}

(A)
FJERRIT. SLEV - 2

( B )
GASSUM - 1

(C)
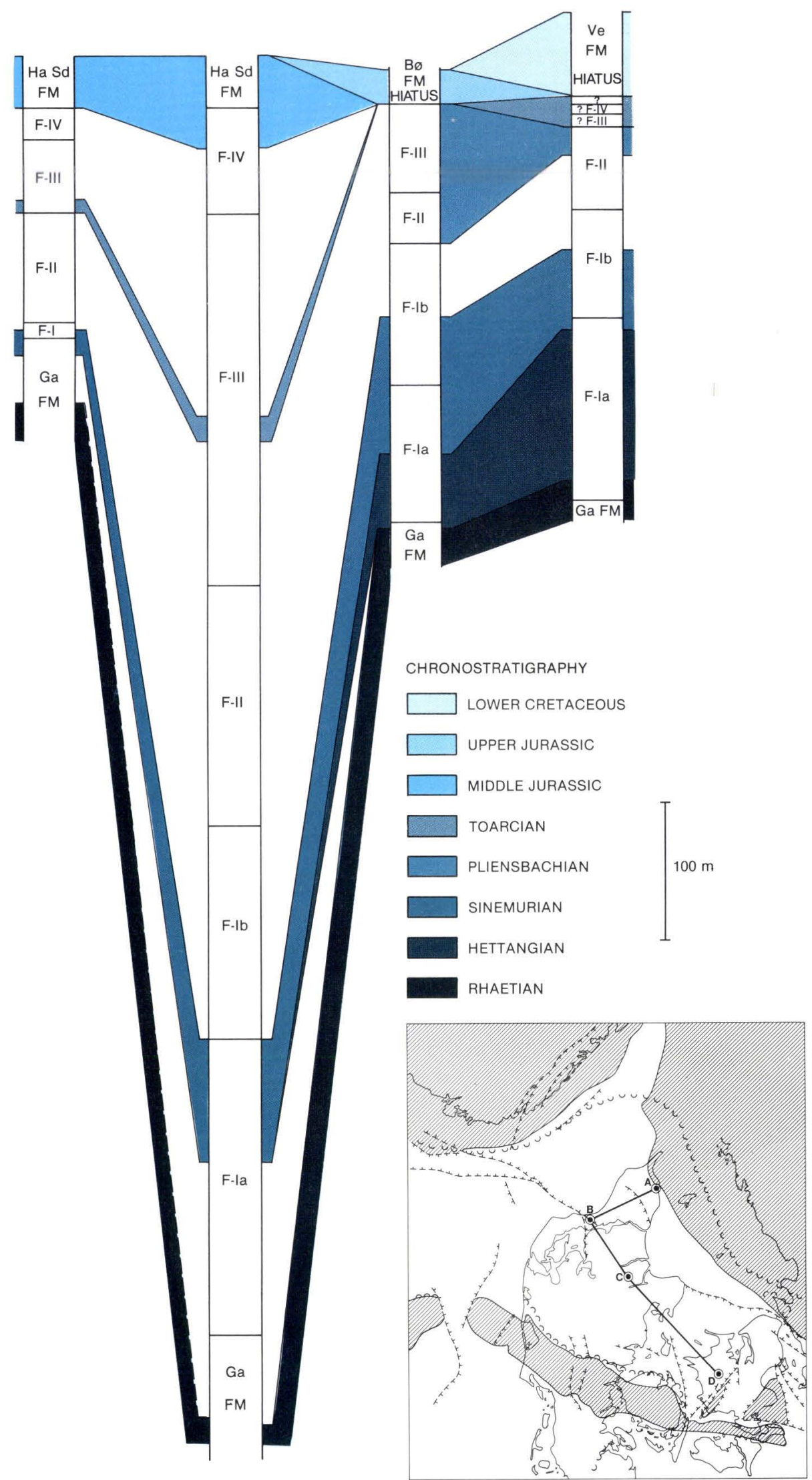

Fig. 11. Correlation of the lithostratigraphic units of the Fjerritslev Formation, based on the chronostratigraphic results presented here. The presence of the F-III Member and the F-IV Member in the Stenlille-2 borehole is based on the biostratigraphical-and palynofacies results from this study. The blank areas indicate intervals of questionable age.

Ga FM: Gassum Formation. Ha Sd FM: Haldager Sand Formation.

Bø FM: Børglum Formation. Ve FM: Vedsted Formation. 


\section{Palynofacies analysis}

\section{Introduction}

The term "palynofacies" is used here to refer to the general aspect of the total kerogen content in the investigated slides, in accordance with the original definition of the term by Combaz (1964). Palynofacies analysis is most commonly utilized for palaeoenvironmental interpretations but it is also a useful technique for studies of maturation and source potential.

Interpretation of the broad depositional environment of the Fjerritslev Formation has been included in several previous studies (e.g. Michelsen 1975, 1978, Pedersen 1983, 1985, 1986, Thomsen et al. 1987). The present study aims to characterize the general composition of the organic matter in a well-documented depositional environment, and to show the variability that may occur within such a lithologically uniform formation as the Fjerritslev Formation.

\section{Kerogen classification}

Unfortunately, there are large differences of opinion concerning the classification and terminology that should be applied to the particulate organic matter found in sediments. This controversy has been intensified by the use of different methods (transmitted light versus reflected light microscopy) and by the differing approaches and objectives of the investigations that employ these methods (e.g. "kerogen typing" for source rock assessment versus "palynofacies" for palaeoenvironmental analysis). The current confusion emphasises the fact that coal maceral terminology should never be applied to transmitted light observations.

The term "kerogen" is used here in the sense of Brooks (1981, p. 2) to refer to "disseminated organic matter of rocks that is insoluble in non-oxidising mineral acids, bases, and organic solvents".

\begin{tabular}{|c|c|c|c|}
\hline MAIN CATEGORIES & SUB-CATEGORIES & DESCRIPTION/DEFINITION & REMARKS \\
\hline Palynomorphs & & $\begin{array}{l}\text { Microspores, pollen, acritarchs, dinoflagel- } \\
\text { late cysts, prasinophysean algae, limnic } \\
\text { algae, and foraminiferal testlinings }\end{array}$ & $\begin{array}{l}\text { The percentage variations of the main } \\
\text { morphological groups of palynomorphs are } \\
\text { based on the biostratigraphical counting (figs } \\
13,15 \text { and } 17 \text { ). }\end{array}$ \\
\hline \multirow{5}{*}{$\begin{array}{l}\text { Terrestrial } \\
\text { plant } \\
\text { debris } \\
\text { (phytoclasts) }\end{array}$} & Brown wood & $\begin{array}{l}\text { Partly or totally translucent, brownish to } \\
\text { black, rounded to angular fragments, often } \\
\text { exhibiting longitudinal structural thicken- } \\
\text { ings }\end{array}$ & \multirow{2}{*}{$\begin{array}{l}\text { Batten (1973) introduced the terms "brown } \\
\text { wood" and "black wood", but with slightly } \\
\text { different definitions than adopted here. The } \\
\text { two categories were subdivided into three } \\
\text { subgroups, based on the size of the grains: } \\
<20 \mu \mathrm{m}, 20-80 \mu \mathrm{m} \text {, and }>80 \mu \mathrm{m} \text {, in order to } \\
\text { assess sorting effects related to the energy } \\
\text { levels in the depositional environment. }\end{array}$} \\
\hline & Black wood & $\begin{array}{l}\text { Totally opaque, rounded to angular with } \\
\text { no visible structures }\end{array}$ & \\
\hline & $\begin{array}{l}\text { Cuticle and } \\
\text { membranes }\end{array}$ & $\begin{array}{l}\text { Yellow to colourless, thin, platy fragments, } \\
\text { with (cuticle) or without (membranes) } \\
\text { cellular structures. }\end{array}$ & $\begin{array}{l}\text { Most of the membraneous particles recorded } \\
\text { probably represent degraded cuticle. }\end{array}$ \\
\hline & Resins & & \multirow{2}{*}{$\begin{array}{l}\text { These two categories were recorded in such } \\
\text { low numbers (maximum one particle per } \\
\text { slide) that they were excluded from the } \\
\text { calculation and presentation of percentage } \\
\text { variations. }\end{array}$} \\
\hline & Fungal remains & Hyphae and spores & \\
\hline $\begin{array}{l}\text { Amorphous organic } \\
\text { matter (A.O.M.) }\end{array}$ & & & $\begin{array}{l}\text { Several varieties of A.O.M. were recog- } \\
\text { nized, but it was impossible to subdivide the } \\
\text { A.O.M. into well-defined subgroups. }\end{array}$ \\
\hline
\end{tabular}

Table 7. 
The deposition of kerogen particles depends on their origin, mode of transportation, buoyancy and density, just as for mineral particles. They can be reworked several times and may become chemically oxidised or biodegraded. However, the resulting kerogen assemblage in a sediment still reflects many aspects of the depositional environment, such as the energy regime, the redox conditions, and the salinity. In order to obtain as much information about these factors as possible, a relatively detailed classification of the kerogen particles must be made. The kerogen particles recorded in this study were grouped into the categories shown in Table 7.

The palaeoenvironmental indications of these categories are discussed in details in Appendix F.

\section{Palaeoenvironmental parameters}

The reliability of a specific kerogen-category as an indicator of changes in the depositional environment depends very much on the overall depositional setting and the stratigraphic period in question. For example, the ratio dinoflagellate cysts/sporomorphs has been used (e.g. Davey 1971, Scott 1982, Piasecki 1986) as an indication of the degree of freshwater-influence on a marine environment. This ratio was not used in this study, since the diversification of dinoflagellate cyst species was in its initial stages in the Early Jurassic. The variation recorded could thus be a reflection of the evolution of this group rather than of environmental conditions. The ratio of the total marine palynomorphs (dinoflagellate cyst, acritarchs, prasinophycean algae, and foraminiferal test-linings) versus the terrestrial + limnic palynomorphs (microspores, pollen and limnic algae) was calculated instead.

Additional problems arise if one tries to interpret variations in the relative percentage-abundances of the kerogen categories. It is not possible to deduce whether the individual category actually varies, or if the apparent variation is due to changes in abundance of other kerogen-categories. In order to make reliable interpretations, therefore it is necessary to use ratios of specific kerogen-categories, or to calculate "absolute" abundances, by including the Total Organic Carbon (T.O.C.)-values.

The parameters presented in table 8 were thought to be valuable as environmental indicators in the sequences investigated here.

\begin{tabular}{|c|c|c|c|}
\hline PARAMETER & DEFINITION & ENVIRONMENTAL SIGNIFICANCE & REMARKS \\
\hline PhytOC & $\begin{array}{l}\text { (\% brown wood }+ \\
\% \text { black wood }+ \\
\% \text { cuticle }) \\
\times \text { T.O.C. }\end{array}$ & $\begin{array}{l}\text { An increase in the PhytOC-value indicates an } \\
\text { increased amount of terrestrially-derived } \\
\text { organic matter, either due to closer proximity } \\
\text { to eustaries or river-mouths, or to an increased } \\
\text { supply. }\end{array}$ & \multirow{2}{*}{$\begin{array}{l}\text { The parameters PhytOC and AmexOC were } \\
\text { introduced by Tyson (1988). } \\
\text { Here the AmexOC-parameter has been used } \\
\text { in a slightly modified form to include all } \\
\text { A.O.M. recognized under the light-micro- } \\
\text { scope, whereas Tyson (1989) only included } \\
\text { fluorescent A.O.M. and exinitic compo- } \\
\text { nents. }\end{array}$} \\
\hline AmexOC & $\begin{array}{l}\% \text { Amorphous } \\
\text { Organic Matter } \\
\text { (A.O.M.) } \\
\times \text { T.O.C. }\end{array}$ & $\begin{array}{l}\text { High AmexOC-values indicate an environment } \\
\text { with variable degrees of oxygen-deficiency in } \\
\text { the bottom waters. }\end{array}$ & \\
\hline$\frac{\text { Saccate pollen }}{\text { spores }}$ & $\begin{array}{l}\text { The ratio of bi- } \\
\text { saccate pollen to } \\
\text { microspores }\end{array}$ & $\begin{array}{l}\text { An increase in this ratio indicates increased } \\
\text { distance to shorelines and freshwater sources. }\end{array}$ & \\
\hline$\frac{P+N}{A}$ & $\begin{array}{l}\text { The ratio of: } \\
\text { (Polygonomorphitae } \\
\text { + Netromorphitae)/ } \\
\text { Acanthomorphitae }\end{array}$ & $\begin{array}{l}\text { An increase in this ratio indicates increased } \\
\text { water-depth. }\end{array}$ & $\begin{array}{l}\text { Polygonomorphitae, Netromorphitae, and } \\
\text { Acanthomorphitae represent three acritarch- } \\
\text { subgroups. }\end{array}$ \\
\hline $\begin{array}{l}\text { \% Marine } \\
\text { palynomorphs }\end{array}$ & $\begin{array}{l}\text { \% Marine palyno- } \\
\text { morphs in relation } \\
\text { to the total number } \\
\text { of palynomorphs }\end{array}$ & $\begin{array}{l}\text { An increase in the relative abundance of ma- } \\
\text { rine palynomorphs indicates a decrease in } \\
\text { freshwater influence within the marine envi- } \\
\text { ronment. }\end{array}$ & $\begin{array}{l}\text { Marine palynomorphs encompass dinoflagel- } \\
\text { late cysts, acritarchs, prasinophysean algae, } \\
\text { and foraminiferal testlinings. }\end{array}$ \\
\hline
\end{tabular}

Table 8 .

The parameters outlined above are used in the following section to interpret the vertical and lateral variations in the depositional environment of the Fjerrit- slev Formation. The usefulness of these parameters will be evaluated by comparing the results with earlier environmental interpretations. 


\section{Palynofacies results}

\section{Introduction}

The results from the palynofacies investigation are presented in figs 12, 14, 16 and 18, and in appendices A-D.

On the basis of the results from the biostratigraphical counting, the relative abundances of the main morphological groups of palynomorphs have been calculated for the three boreholes Fjerritslev-2, Frederikshavn-2, and Stenlille-2. These results are presented in figs 13,15 and 17. Corresponding curves for the Jurassic sequence in the Gassum-1 borehole were presented by Dybkjær (1988, fig. 10). In addition, the relative abundance of marine palynomorphs, and the ratios of saccate pollen/spores, and (Polygonomorphitae $+\mathrm{Ne}$ tromorphitae)/Acanthomorphitae (three acritarch subgroups) are shown. These results will be included in the interpretation of the results from the palynofacies investigation.

\section{General environmental interpretation of the Gassum and Fjerritslev Formations}

The kerogen assemblages in the Gassum Formation, in all four investigated boreholes, generally indicate a low salinity environment with a very high influx of terrestrially derived organic matter and well oxygenated bottom water. These observations correlate very well with earlier interpretations of this formation as being of fluvio-deltaic origin (Bertelsen 1978) or shallow marine to fluvial (Nielsen, Larsen \& Frandsen 1989). In the uppermost parts of the Gassum Formation the records of marine palynomorphs herald the marine depositional environment of the succeeding Fjerritslev Formation.

The kerogen assemblages in the samples referred to the Fjerritslev Formation generally show the same overall composition in all four boreholes. The presence of marine palynomorphs in all samples clearly indicates a marine depositional environment for the whole of this formation. However, the dominance of brown wood among the kerogen particles, especially in the lower part of the formation, indicates a high influx of terrestrially-derived organic matter. This is further supported by low relative abundances of marine palynomorphs, and of saccate pollen. The dominance, among the marine palynomorphs, of acanthomorph acritarchs, indicates a shallow-water environment. Low relative abundances of amorphous organic matter (A.O.M.) (except for a few samples referred to F-III and F-IV member) indicate generally well-oxygenated bottom waters. The brown and black wood particles are mainly of small- or medium-size, with only sporadic representation of coarse particles. According to Davey (1971), this indicates relatively nearshore deposition in a low energy environment. Fluctuations in the energyregime are, however indicated by the changing lithology, especially in the most proximal borehole, Frederikshavn-2.

The results from the palynofacies investigations of the Fjerritslev Formation clearly support the earlier environmental interpretations by Michelsen (1978) and Pedersen $(1985,1986)$.

\section{Stratigraphic variation}

The stratigraphic variations in the kerogen assemblages recorded from the Fjerritslev-2 and Frederikshavn-2 boreholes generally correlate very well with the lithostratigraphic subdivisions of Michelsen (1978), although detailed comparison was not possible because of incomplete core coverage.

The lithostratigraphic subdivision of the Stenlille-2 borehole by Frandsen (1988), correlates with the va-

Fig. 12. Palynofacies results from the Fjerritslev-2 borehole.

I: $\quad$ Total Organic Carbon- (T.O.C.-) content.

II a-e: Relative abundances of the various categories of kerogen particles. $100 \%=$ total kerogen particles counted. The two categories, brown wood (IIb) and black wood (IIc), are further subdivided into size categories, $<20$ microns, 20-80 microns, and $>80$ microns.

III a,b: PhytOC $=(\%$ brown wood $+\%$ black wood $+\%$ cuticle $) \times$ T.O.C. AmexOC $=\%$ Amorphous Organic Matter (A.O.M.) $\times$ T.O.C.

IV: $\quad$ Marine palynomorphs as a percentage of total palynomorphs, based on the results from the biostratigraphical investigation.

$V$ a: $\quad$ Palynomorph preservation. Palynomorphs were not recorded in samples marked with an asterisk.

$V b: \quad$ Degree of sorting. 
THE FJERRITSLEV No. 2 BOREHOLE

CURONO HTHO DEPTH SAMPLES TOC

PAD

STRAT' - STRATI- DRAPHY M. B.,

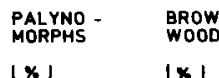

BLACK CU- A.O.M. PHYTOC
WOOD
IXI

AMEXOC MARINE PALYNO- DEGREE OF

ITHIS IMOYCHELSEN

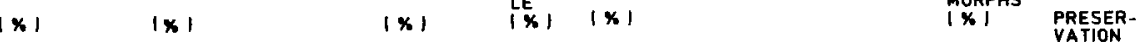

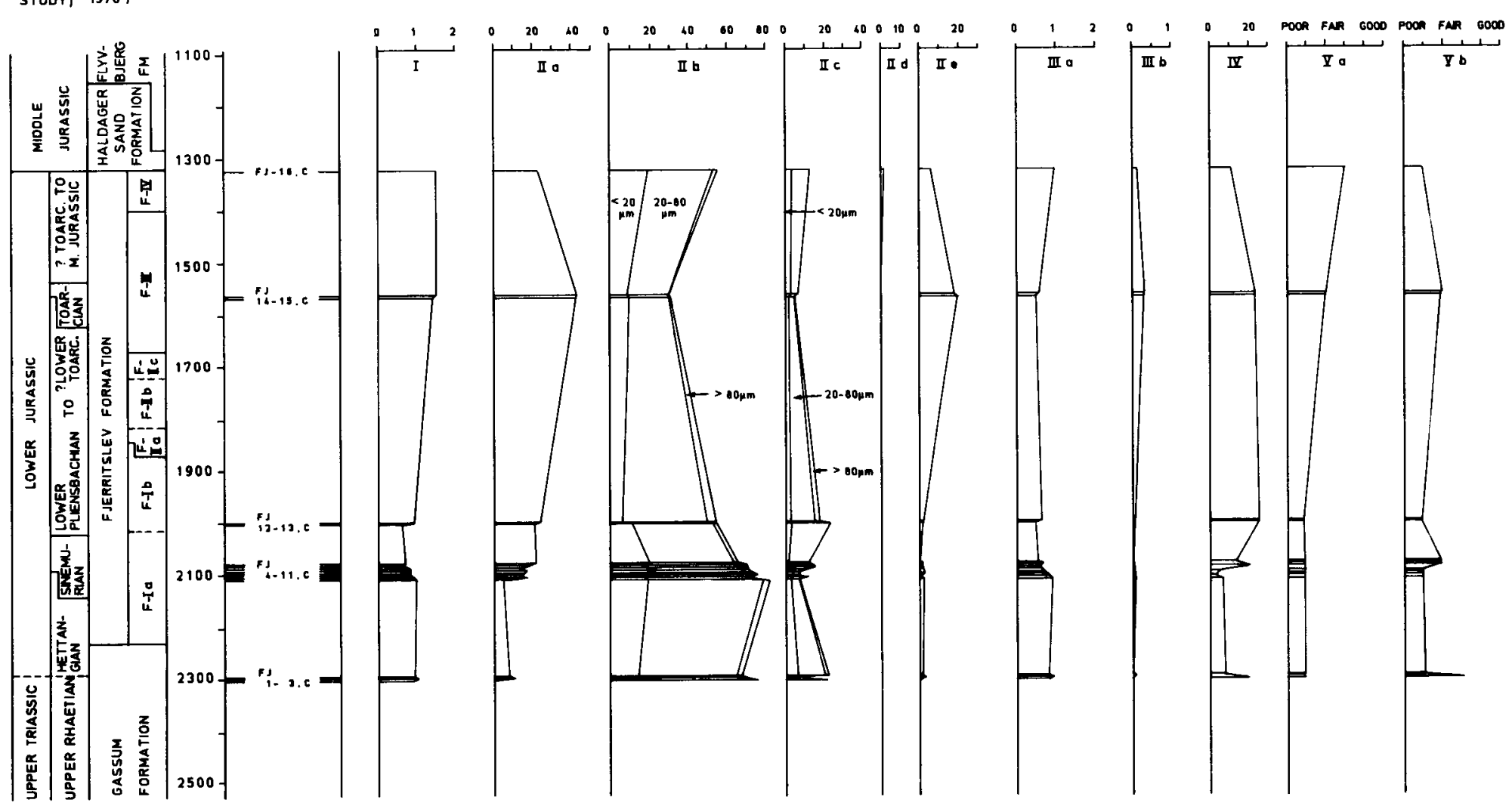


riations in the kerogen assemblages in the lower part of the sequence. In the upper part of the sequence, assigned to the Lower Cretaceous by Frandsen (1988), the intervals represented by samples St- 15 , w and St-16,w showed kerogen assemblages that are more closely comparable with assemblages recorded from the F-III member and the F-IV member, respectively, from the Fjerritslev-2 borehole. This is supported by the biostratigraphical investigation which referred these two samples to the Toarcian. In order to compare the sequences investigated, these samples will be included in discussion of the F-III and F-IV members, respectively.

The stratigraphic variations in the kerogen-assemblages in the Fjerritslev-2, Frederikshavn-2 and Stenlille-2 boreholes generally show a high degree of correlation. The stratigraphic variation in the kerogen-assemblages from the Gassum-1 borehole, however, does not correlate with those recorded in the other three boreholes, nor with the lithostratigraphic subdivision of this sequence proposed by Pedersen (1986, fig. 6).

General variations in the kerogen assemblages from Fjerritslev-2, Frederikshavn-2 and Stenlille-2 are discussed below in relation to the lithostratigraphical units. The kerogen assemblages from Gassum-1 will be discussed separately. The differences in the kerogen assemblages between the lithostratigraphical units are shown for each of the four boreholes in fig. 19 (part c).

\section{The Gassum Formation:}

Samples referred to the Gassum Formation were obtained from all three boreholes. The samples are relatively coarse-grained, comprising sandstone, siltstone and sandy and silty claystone, in contrast to the samples referred to the Fjerritslev Formation (see appendices A-C).

The kerogen assemblages are strongly dominated by brown wood (figs 12, 14 and 16). As relatively high T.O.C.-values were also recorded (especially from the Frederikshavn-2 borehole, sample Frh-1,c and Frh-4,c), maximum PhytOC-values characterize this level, indicating a high influx of terrestrially-derived organic matter, and/or proximity to the source. The amount of black wood varies, but is generally high, especially in some of the most coarse-grained samples (for example Fj-1,c, Fj-3,c and Frh-4,c). Well-oxygenated bottom waters is indicated by the distinctly low AmexOC-values.

The relative abundance of marine palynomorphs is generally low, but show relatively high abundances in a few samples (for example $\mathrm{Fj}-2, \mathrm{c}$ and $\mathrm{St}-2, \mathrm{c}$ ) from the uppermost part of the Gassum Formation.

Among the terrestrial palynomorphs, non-saccate pollen dominate strongly in the Fjerritslev- 2 and Stenlille-2 boreholes, whereas distinctly low amounts of bisaccate pollen were recorded. Among the non-saccate pollen the two species Ricciisporites tuberculatus and Corollina torosus clearly form the major part. The former species is known to occur in high relative abundances in relatively coarse-grained samples, and indicates proximity to a freshwater source. The environmental significance of Corollina torosus is more complex and not fully understood.

In Frederikshavn-2 the terrestrial palynomorphs are dominated by spores but non-saccate pollen also show high relative abundances.

The transition from the Gassum Formation to the Fjerritslev Formation is clearly reflected in the kerogen assemblages in all three boreholes. A distinct decrease in the PhytOC-values (see fig. 19, and Appendix E)

Fig. 13. Relative abundances of the main morphological groups of palynomorphs in the Fjerritslev-2 borehole.

I: $\quad$ Marine versus terrestrial + limnic palynomorphs. $100 \%=$ total of palynomorphs.

II a-c: Relative abundances of the main morphological groups of terrestrial palynomorphs. $100 \%=$ total of terrestrial palynomorphs.

III: Ratio of saccate pollen/microspores.

IV a-g: Relative abundances of the main morphological groups of aquatic palynomorphs. $100 \%=$ total of aquatic palynomorphs (=marine palynomorphs + freshwater algae).

V: Ratio of (Polygonomorphitae + Netromorphitae)/ Acanthomorphitae. 
THE FJERRITSLEV No. 2 BOREHOLE

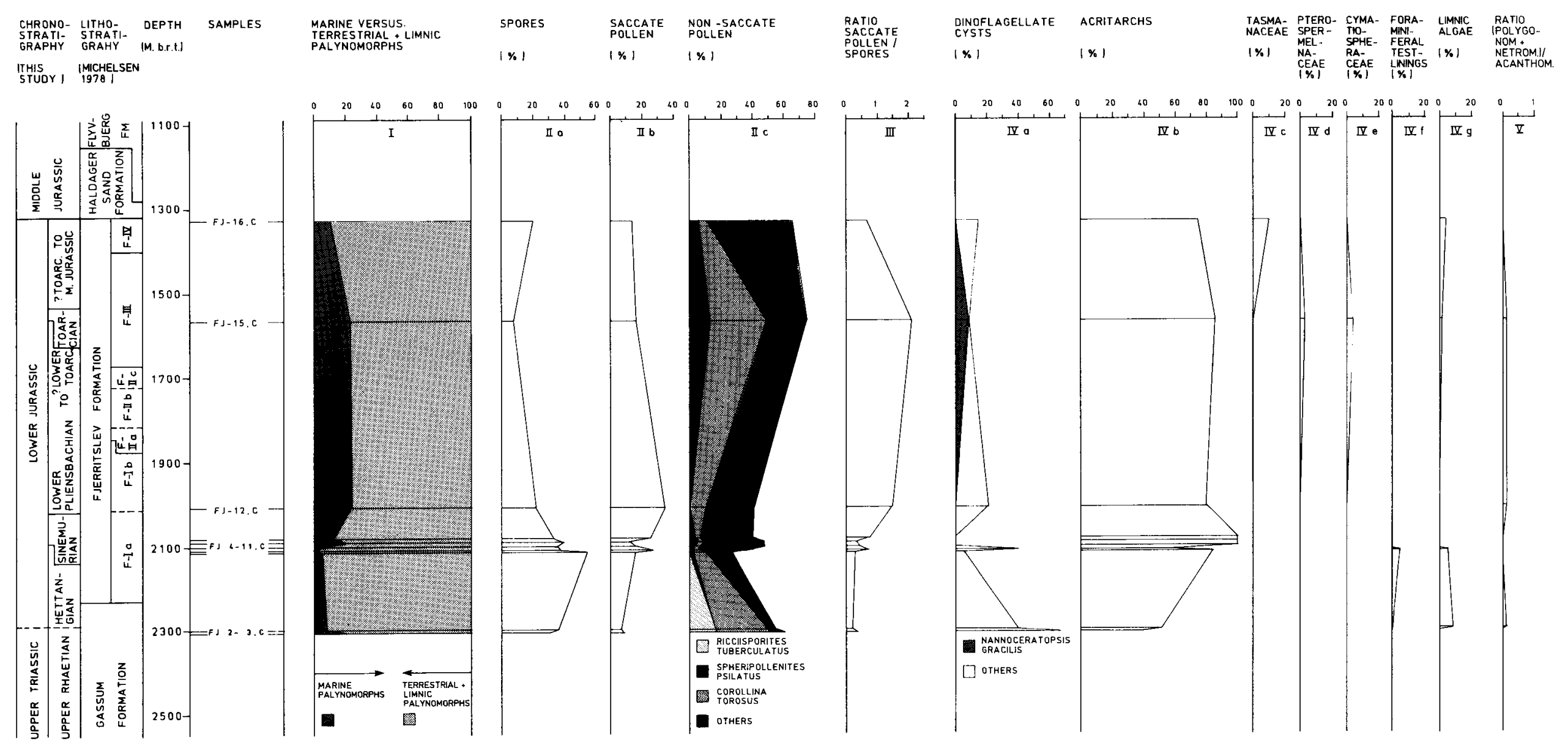


clearly indicates a reduced influx of terrestrially-derived organic matter. An associated increase in the ratio of saccate pollen/spores indicates an increased distance to shorelines (or river-mouths). The increase in the ratio (Polygonomorphitae + Netromorphitae)/ Acanthomorphitae (in Frederikshavn-2 and Stenlille-2) further indicates a general increase in water depth. The AmexOC-values and the relative abundances of marine palynomorphs are more or less constant. The decrease in the relative abundance of marine palynomorphs in Stenlille-2 is due to the atypically high levels of marine palynomorphs in sample $\mathrm{St}-2$,c which is the uppermost sample referred to the Gassum Formation.

Together the changes in the kerogen assemblages clearly reflect the overall sea-level rise resulting in the transition from the fluvio/deltaic Gassum Formation to the marine Fjerritslev Formation.

In the Frederikshavn-2 borehole the "old" F-I member, as defined by Michelsen (1978), has not been subdivided into a F-Ia and F-Ib member. The samples referred to the F-I member in this borehole generally show a dominance of brown wood, although not to the extent observed in the Gassum Formation. The PhytOC-values are significantly lower than those recorded from the Gassum Formation, mainly because of lower T.O.C.-values. Low AmexOC values indicate well-oxygenated bottom waters. Among the terrestrial palynomorphs, the ratio of saccate pollen/spores shows distinctly higher values than in the Gassum Formation indicating a greater distance to the shoreline. Acanthomorph acritarchs dominate the marine palynomorphs, indicating a shallow-water environment.

\section{The F-Ia member:}

The F-Ia member is represented in the Fjerritslev- 2 and
Stenlille-2 boreholes. The kerogen assemblages recorded from this member are generally dominated by brown wood, but show marked variations, even between closely spaced samples.

These observations correspond very well with the lithological interpretations by Michelsen (1978) and Pedersen (1986). The F-Ia member shows the greatest lithological variation of the entire formation, and was interpreted as being the most coast-near, deposited in a well-oxygenated shallow-water environment and with changing energy levels.

\section{The F-Ib member:}

No cores exist from the interval referred to the F-Ib member in the Stenlille-2 borehole.

The samples referred to the F-Ib member in Fjerritslev-2 show slightly lower PhytOC-values than the samples referred to the F-Ia member, indicating a reduced supply of terrestrially derived organic matter. A decrease in freshwater influence is indicated by a general increase in the relative abundance of marine palynomorphs. A concurrent increase in the ratio of (Polygonomorphitae + Netromorphitae)/Acanthomorphitae indicates an increase in water depths passing from the F-Ia to the F-Ib member. These interpretations are supported by a distinct increase in the ratio of saccate pollen/spores, indicating a greater distance to the shoreline.

In accordance with Michelsen (1978) the kerogen assemblages from this member indicate a depositional environment very similar to that envisaged for the F-Ia member, but with slightly deeper water conditions. However, according to Michelsen $(1975,1978)$, the ostracod fauna indicated reducing conditions; no indications of oxygen deficiency in the bottom waters were recorded here. 
THE FREDERIKSHAVN NO. 2 BOREHOLE

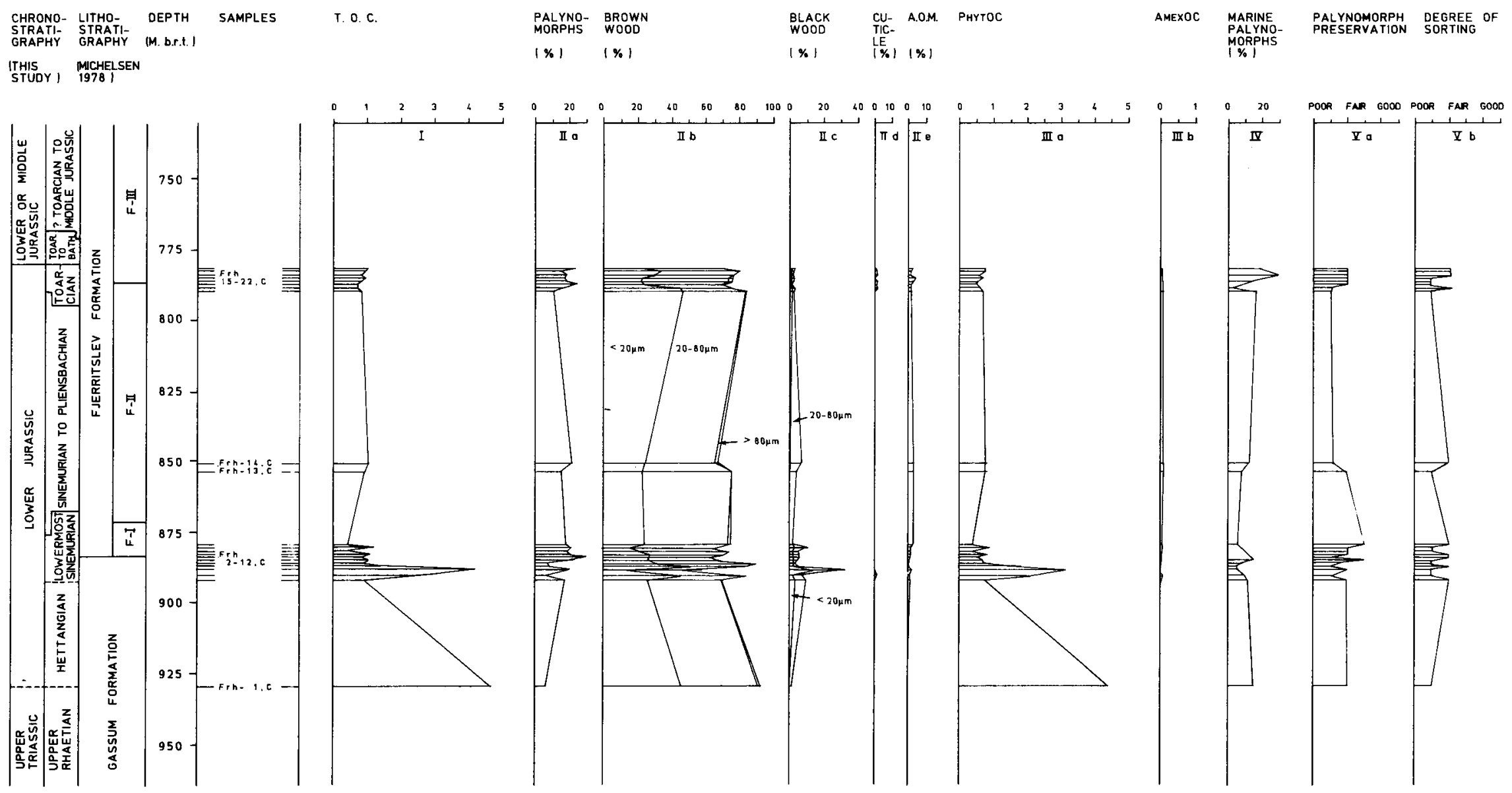


Due to incomplete coring, samples from the F-Ib member and F-II member were not obtained from the same borehole. Thus possible changes in the kerogen assemblage between these two units cannot be investigated.

In the Frederikshavn- 2 borehole, a weak increase in relative abundance of PhytOC-values was recorded passing from the F-I member to the F-II member (see Appendix E), indicating an increased influx of terrestrially-derived organic matter. This conflicts, however, with a concurrent increase in the ratios saccate pollen/spores and (Polygonomorphitae + Netromorphitae)/Acanthomorphitae, indicating increased distance to the shoreline, and a deeper-water regime, respectively. The reason for this apparent contradiction is presently not clearly understood.

In the Stenlille-2 borehole, a marked decrease in PhytOC-values from the F-Ia member to the F-II member indicates a reduced influx of terrestrially-derived organic matter. The concurrent increase in the ratio of saccate pollen/spores, and a weak increase in the ratio of (Polygonomorphitae + Netromorphitae)/Acanthomorphitae indicate increased distance to the shoreline and increased water depth.

\section{The F-II member:}

The F-II member is represented by samples from the Frederikshavn- 2 and Stenlille- 2 boreholes. They are generally dominated by brown wood, especially in Frederikshavn-2, while samples from Stenlille-2 also show rather high relative abundances of palynomorphs. Amongst the palynomorphs, non-saccate pollen dominate in the Frederikshavn-2 borehole, whereas the three groups of terrestrial palynomorphs in the Stenlille-2 borehole were recorded in more or less equal numbers. Low AmexOC-values from both boreholes indicate well-oxygenated bottom waters.

The overall kerogen assemblage of the F-II member corresponds very well with the earlier interpretations by Michelsen (1978) and Pedersen (1986), indicating a relatively shallow-water environment with well-oxygenated bottom waters.

The transition from the F-II member to the F-III member is represented in cores from the Stenlille-2 and Frederikshavn-2 boreholes.

The transition is clearly reflected in the kerogen assemblages in Stenlille-2. A decrease in PhytOC-values, and a simultaneous marked increase in AmexOC-values, clearly indicate significant environmental changes including a marked reduction in influx of terrestriallyderived organic matter, combined with pronounced oxygen-deficiency in the bottom waters. The decrease in ratios of saccate pollen/spores and (Polygonomorphitae + Netromorphitae)/Acanthomorphitae and the decrease in relative abundance of marine palynomorphs could be due to the overwhelming dominance $(98 \%)$, within the palynomorphs, of one species of alete pollen, Spheripollenites psilatus. This results in there being no record of bisaccate pollen, polygonomorph acritarchs or netromorph acritarchs, and a relative abundance of marine palynomorphs of only $7 \%$.

In Frederikshavn-2, this transition is not reflected in the kerogen assemblage. No distinct changes were recorded in the PhytOC- or the AmexOC-values. However, decreases in the ratios of saccate pollen/spores and (Polygonomorphitae + Netromorphitae)/Acanthomorphitae, indicate a reduced distance to the shoreline, and a shallow-water regime. These interpretations contrast with the marked increase in the relative abundance of marine palynomorphs, indicating a decreased freshwater influence.

Fig. 15. Relative abundance of the main morphological groups of palynomorphs in the Frederikshavn-2 borehole. For further $\rightarrow$ explanation, see text to fig. 13. No specimens referred to the Pterospermellaceae (IVd) were recorded from this borehole. 
THE FREDERIKSHAVN No. 2 BOREHOLE

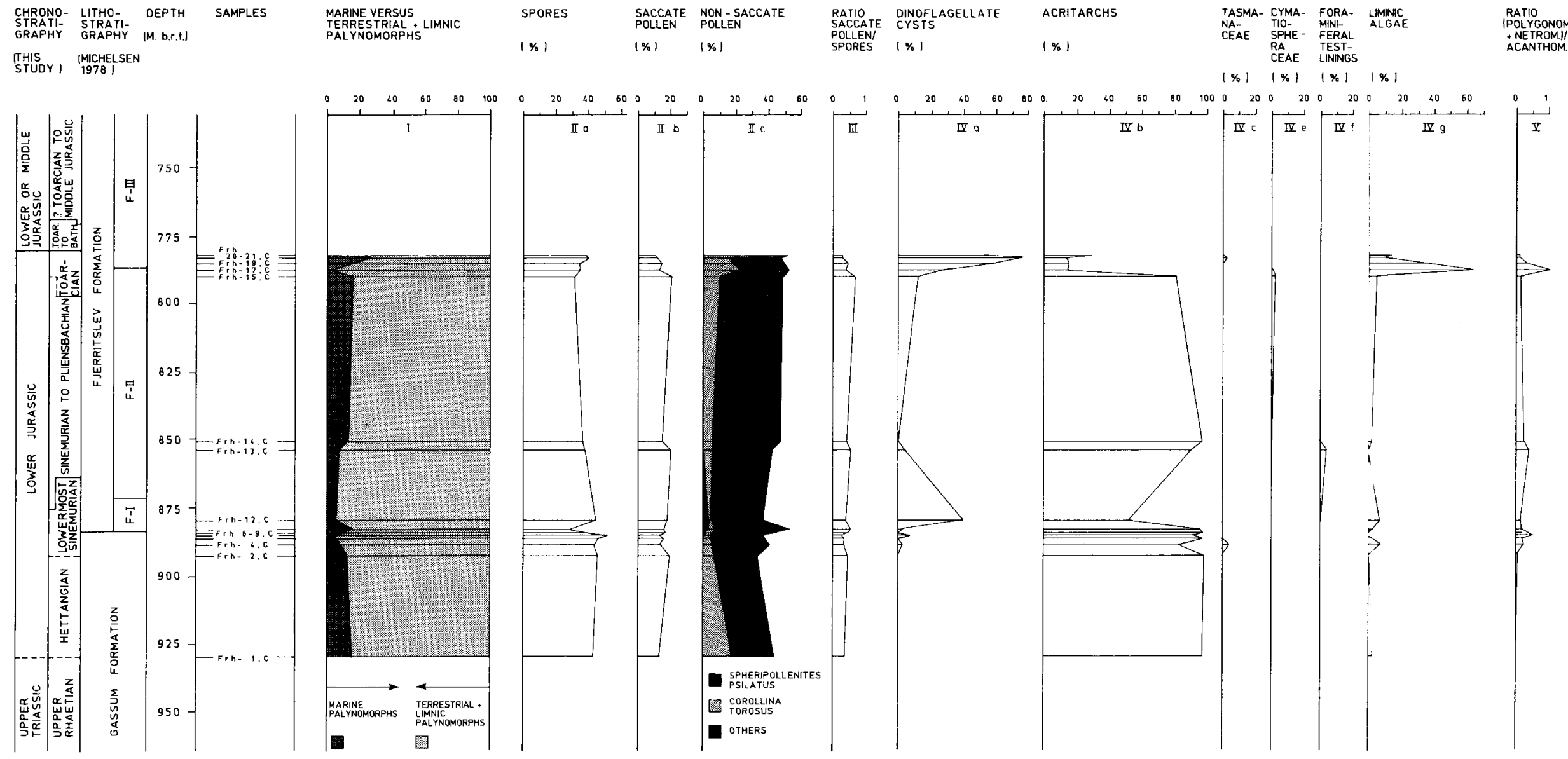




\section{The F-III member:}

Core samples referred to the F-III member are available from the Fjerritslev-2, Frederikshavn-2, and (probably) from the Stenlille-2 boreholes (see discussion on p. 52).

The kerogen assemblages from the F-III member in Fjerritslev-2 and Stenlille-2 are clearly different from the underlying F-II member assemblages. The main difference is the high AmexOC-values in these samples, a result of high relative abundances of A.O.M. combined with relatively high T.O.C.-values. These observations indicate oxygen deficiency in the bottom waters, resulting in a high preservation of organic matter. The PhytOC-values in Fjerritslev-2 are comparable with those from the F-Ia, F-Ib and F-II members, indicating that the supply of terrestrial phytoclasts was relatively constant. In Stenlille 2, however, a distinct minimum in PhytOC has been recorded, indicating a very low influx of terrestrially-derived organic matter. Amongst the terrestrial palynomorphs, the non-saccate pollen are dominant; the species Spheripollenites psilatus shows particularly high relative abundances. The marine palynomorphs show rather high relative abundances in Fjerritslev-2, while low relative abundances were recorded in Stenlille-2.

This association of high relative abundances of A.O.M. and Spheripollenites is recognized widely across NW-Europe in black bituminous shales deposited during the Early Toarcian transgressive anoxic event (Wall 1965, Wille 1982, Riegel et al. 1986). Correlation with this "anoxic event" is further indicated by the composition of the marine palynomorph assemblage. The only dinoflagellate cyst genus recorded from this level in this study is Nannoceratopsis. Furthermore, relatively high abundances of Prasinophysean algae and a maximum of Pterospermella were recorded. Nan- noceratopsis is one of the few dinoflagellate cyst genera that has been recorded from Early Toarcian bituminous strata where it occurs together with Prasinophycean algae (Wall 1965, Wille 1982, Riegel et al. 1986).

The relatively high T.O.C. values recorded from the F-III member, reflect good preservation of organic matter, probably due to oxygen deficiency in the bottom waters (resulting in reduced levels of bioturbation and thus less bacterial degradation (see Tyson 1987)). This is further supported by the relatively good palynomorph preservation at this level compared with the underlying samples (figs 12 and 16).

The kerogen assemblages recorded from samples referred to the F-III member in the Frederikshavn-2 borehole do not show any appreciable difference from the assemblages referred to the F-I and F-II members. The assemblage is overwhelmingly dominated by brown wood, with only a few percent of A.O.M. The palynomorph assemblage is diverse, with a composition comparable to that seen in the sequence below.

The kerogen assemblages of the F-III member in the Fjerritslev-2 and Stenlille-2 boreholes clearly support the interpretation by Michelsen (1978) of a deeperwater environment, with progressively reducing conditions in the bottom waters. One level of the Stenlille-2 borehole, sample St-15,w (1234m b.r.t.) assigned an Early Toarcian age, showed a kerogen assemblage indicating severe oxygen-deficiency. A corresponding, but less oxygen-deficient level, was recorded from Fjerritslev-2, sample Fj-15,c (1561m b.r.t.).

In contradiction, the kerogen assemblages from Frederikshavn-2 clearly indicate that neither oxygen deficiency nor special palynomorph assemblages developed in this area during the deposition of F-III member.

The transition from the F-III member to the F-IV member is represented in the Fjerritslev-2 and, accord-

Fig. 16. Palynofacies results from the Stenlille-2 borehole. For further explanation, see text to fig. 12. 
THE STENLILLE NO. 2 BOREHOLE

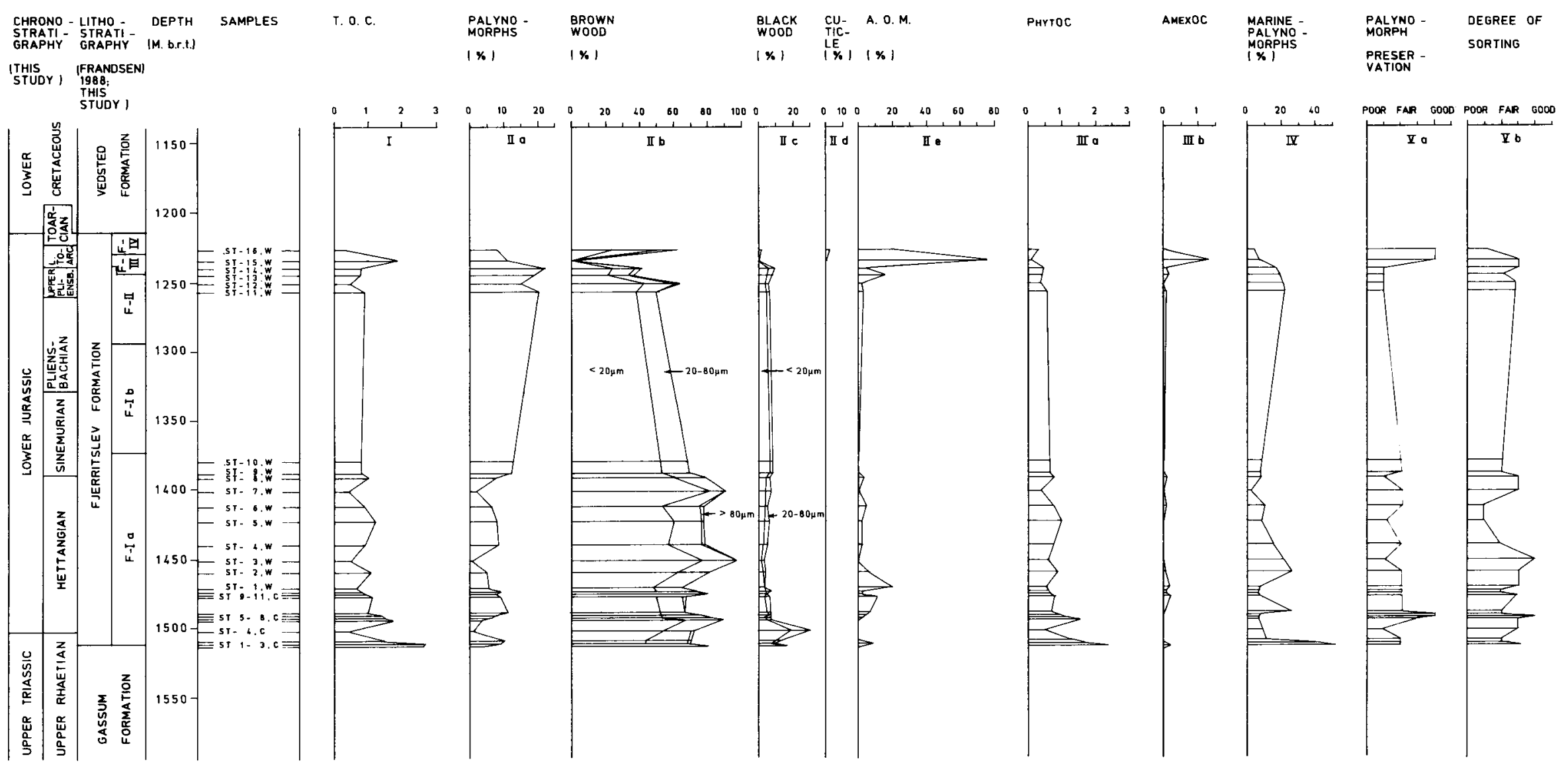


ing to the interpretation given here, the Stenlille- 2 boreholes, where it is clearly reflected by changes in the kerogen assemblages. Marked increases in PhytOCvalues and decreases in AmexOC-values (fig. 19) indicate an increased input of terrestrially-derived organic matter, and increasing oxygen levels in the bottom waters. In addition the ratios of saccate pollen/spores and (Polygonomorphitae + Netromorphitae)/Acanthomorphitae decrease, indicating shallower water and a shorter distance to the shoreline.

\section{The F-IV member:}

The F-IV member is represented by one sample from the Fjerritslev-2 and one sample from the Stenlille-2 borehole (see discussion on p. 52). The kerogen assemblages are dominated by brown wood, and show higher PhytOC-values than in the F-III member, indicating a higher input of terrestrially-derived organic matter. The AmexOC-values are clearly lower than in the F-III member, but generally higher than in the F-Ia, F-Ib and F-II members. These observations indicate mildly reducing conditions in the bottom waters, as supported by fairly good palynomorph preservation (figs 12 and 16). Non-saccate pollen dominate the terrestrial palynomorphs. The relative abundance of spores is, however, higher than in the F-III member. The two species of non-saccate pollen, Spheripollenites psilatus and especially Corollina torosus, show significantly lower relative abundances than in the F-III member. The marine palynomorphs show a low relative abundance, especially in Stenlille-2, where this group consists exclusively of acanthomorph acritarchs, strongly indicating a shallow water regime. In Fjerritslev-2, a more diverse aquatic palyno-flora was recorded. A maximum in the relative abundance of fresh- water algae indicates proximity to a freshwater source. The associated maximum of Tasmanites is suggestive of brackish water conditions.

Michelsen (1978) proposed a "lagoonal environment" with "strongly reducing conditions" for the deposition of F-IV member. The kerogen assemblages of the F-IV member could very well reflect a lagoonal environment, but with only slightly reducing conditions in the bottom waters.

\section{Variations in kerogen-assemblages from Gassum-1}

Slides used for biostratigraphical counting by Dybkjær (1988) were also utilized for kerogen particle counting in this study. Some additional slides (of which several were more or less barren of palynomorphs) were included so as to cover as much lithological variation as possible. In contrast to the other boreholes, the Gassum-1 sequence was extensively cored, allowing more systematic sampling. Samples from the Fjerritslev Formation are lithologically very homogenous, consisting of claystone or silt-streaked claystone. Samples from the Gassum and Bream Formations are generally more coarse-grained.

Variations in the kerogen assemblages from Gassum-1 support neither the lithostratigraphical subdivision indicated by Pedersen (1986, fig. 6) (see fig. 18) nor the general environmental interpretations of the lithological units (fig. 19). Only with respect to the transition from the Gassum Formation to the Fjerritslev Formation do the kerogen assemblages indicate environmental changes that are comparable with earlier interpretations.

Fig. 17. Relative abundance of the main morphological groups of palynomorphs in the Stenlille-2 borehole. For further explanation, see text to fig. 13. No specimens referred to foraminiferal test-linings (IVf) were recorded from this borehole. 
THE STENLILLE No. 2 BOREHOLE

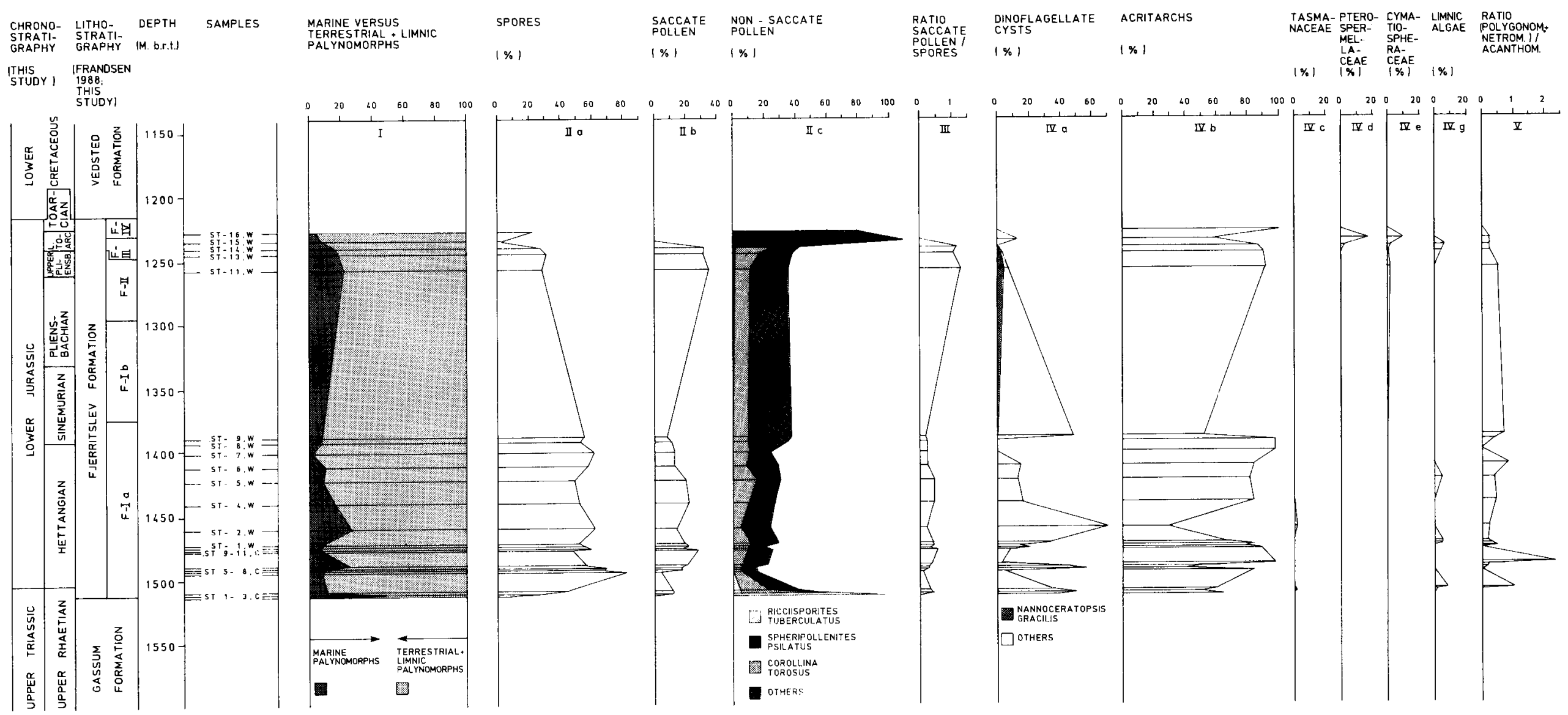




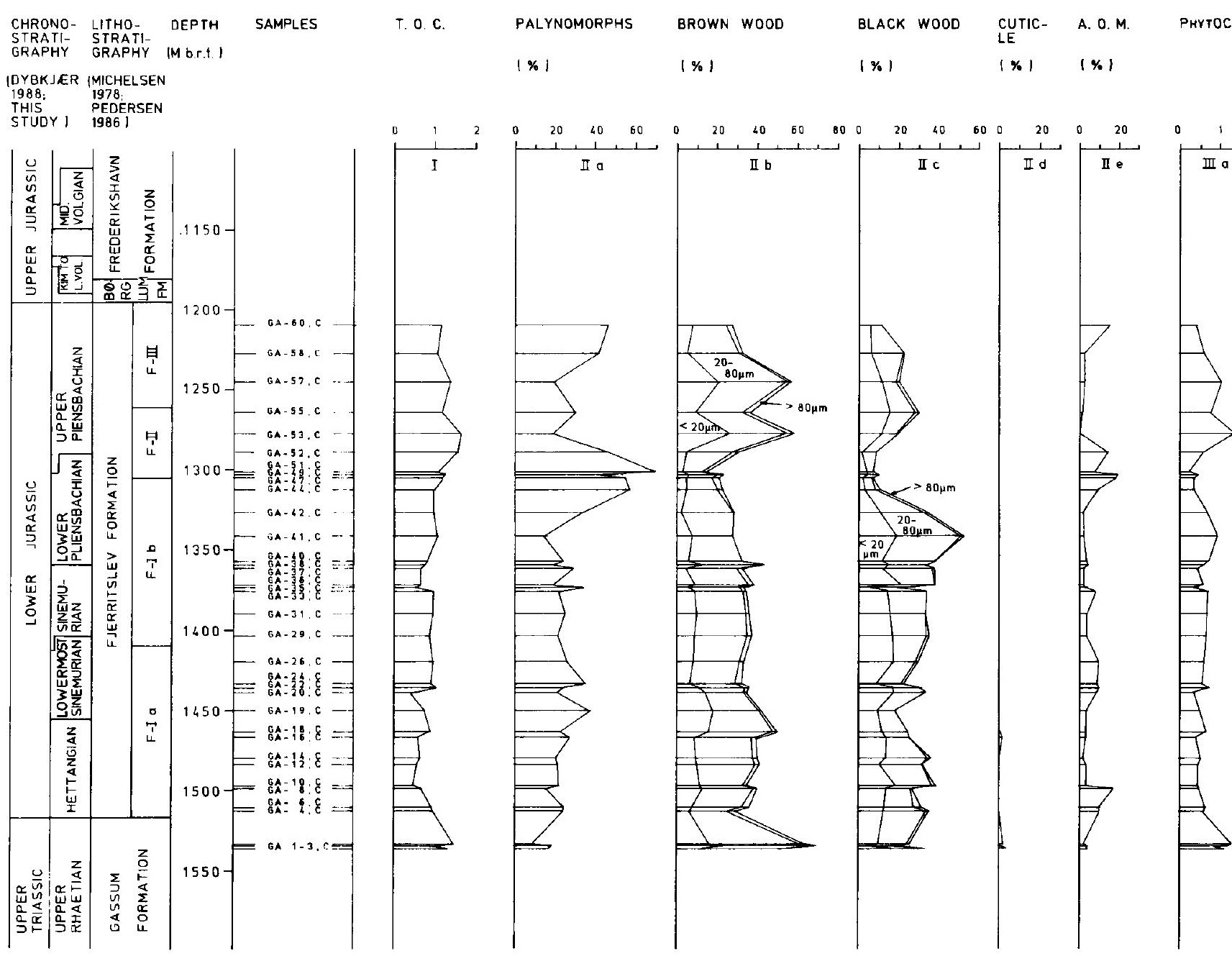

Fig. 18. Palynofacies results from the Gassum-1 borehole.

IV: $\quad$ After Dybkjar (1988).

VI $a, b$ : After Michelsen (1975). The diversity curve shown here is the reverse of that presented by Michelsen (1975, fig. 22), redrawn such that high values indicate high diversity.

VI c: $\quad$ After Pedersen (1986).

VI d: After Nørvang (1957) and Pedersen (1986).

For further explanation, see text to fig. 12.

The kerogen curves show two overall patterns (fig. 18):

a) The curves for palynomorphs, brown wood, black wood, and PhytOC comprise a lower part, with relatively constant values, and an upper part with more variable values.

b) The curves for AmexOC (and relative percentage of A.O.M.) and marine palynomorphs generally correlate very well, showing minor variations throughout the investigated sequence. These minor variations are generally reflected in the patterns shown by the palynomorphs and, inversely, by the brown wood and PhytOC. Furthermore, these trends correlate with the relative abundance of saccate pollen, and show an inverse relationship with the curve for trilete spores (see Dybkjær 1988, fig. 10).
The variations within the kerogen assemblages, and the environmental indications of these changes, are discussed below. The results of the biostratigraphical investigation (Dybkjær 1988) have been included to support the interpretations.

The kerogen assemblages in the samples referred to the Gassum Formation are strongly dominated by phytoclasts, particularly brown wood, indicating a high influx of terrestrially-derived organic matter. Significant terrestrial influence is further supported by the low relative abundances of marine palynomorphs, and the dominance of spores among the terrestrial palynomorphs. Low AmexOC-values indicate well-oxygenated bottom waters.

A marked decrease in the influx of terrestrially-derived organic matter at the transition from the Gassum Formation to the Fjerritslev Formation is indicated by a significant decrease in the PhytOC-values, and an increase in the relative abundance of marine palynomorphs (fig. 19). An increase in AmexOC-values indicates a relative drop in oxygen content of bottom waters. Furthermore, distinct increases in the ratios of saccate pollen/spores and (Polygonomorphitae $+\mathrm{Ne}$ tromorphitae)/Acanthomorphitae indicate increased 

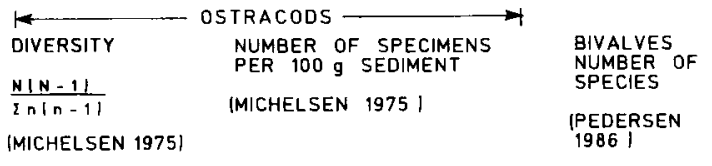

BENTHIC

FORAMINIFERA,

SPECIES

(NORVANG 1957;

(NORVANG $1957 ;$
PEDERSEN 1986)
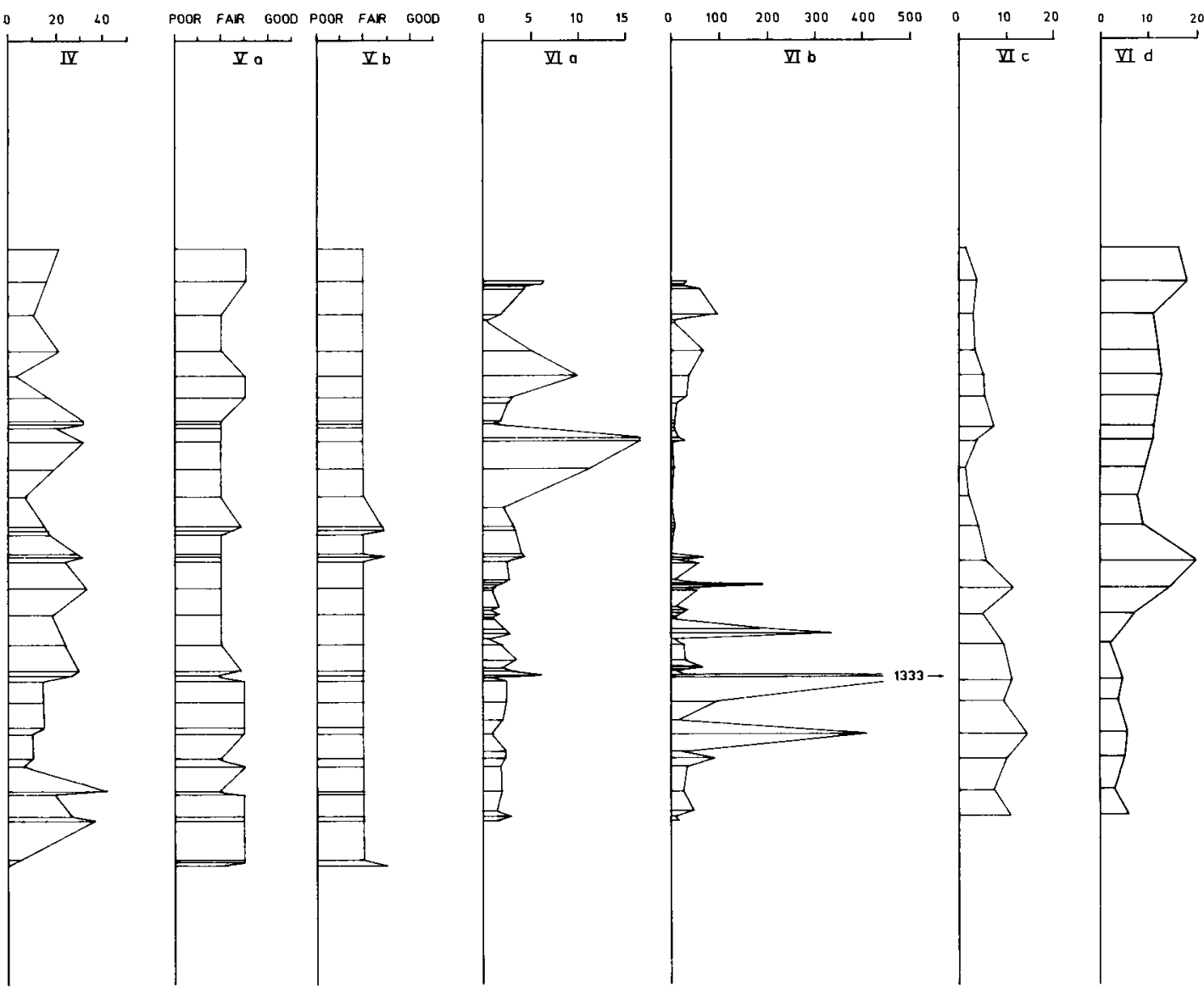

distance to the shoreline, and increased water depths, respectively.

Above this level, in the F-Ia and F-Ib members, up to about sample GA-40 ( $1358 \mathrm{~m}$ b.r.t.), the palynomorph-category, as well as the categories of brown wood, black wood, and PhytOC, only show minor variations. Brown wood generally shows a weak dominance over palynomorphs and black wood.

Above sample GA-40 the kerogen-curves for palynomorphs, brown wood and black wood show significantly greater oscillations. Generally higher T.O.C. values were recorded above this level.

In the lower half of F-II member (GA-44 to GA-52) (1313m-1289m b.r.t.), a minimum of PhytOC was recorded, indicating a significant decrease in the supply of terrestrially derived organic matter. Relatively high AmexOC-values, high relative abundances of saccate pollen, and the dominance of saccate pollen among the terrestrial palynomorphs support this interpretation.

The upper part of the F-II member and most of the F-III member (samples GA-53 to GA-58) $(1277 \mathrm{~m}-1227 \mathrm{~m}$ b.r.t.) are characterized by relatively high PhytOC-values, indicating a relatively high influx of terrestrially-derived organic matter. This is supported by generally low abundances of marine palyno- morphs and low AmexOC-values. The palynomorph assemblage in sample GA-53 is dominated by Ricciisporites tuberculatus (presumed to be reworked); high relative abundances of limnic algae were also recorded. These observations may indicate a short-lived regressive phase resulting in erosion and reworking of older sediments in the marginal areas of the basin (Dybkjær 1988).

A decrease in PhytOC was recorded immediately below the top of the Fjerritslev Formation (sample GA-60)(1210m b.r.t.), in the upper part of the F-III member. At the same level, palynomorphs (mainly the genera Spheripollenites and Corollina) show a high relative abundance. These observations indicate a renewed reduction in the supply of terrestrially-derived organic matter, a conclusion supported by an increase in both the abundance of marine palynomorphs and in AmexOC.

Eventual relations between the observed variations in the kerogen assemblages and previous recorded variations of the bottom fauna from the Gassum-1 borehole (Michelsen 1975, Pedersen 1986), are discussed in the following.

The distinct change in the curve-patterns near the 
boundary between the F-Ib member and the F-II member (sample GA-40, $1358 \mathrm{~m}$ b.r.t.) probably corresponds to the marked drop in diversity and density of both ostracods (Michelsen 1978) (see fig. 18) and bivalves (Pedersen 1986, fig. 6), immediately below this level. This event represents a "turnover" in the ostracod fauna with the appearance of several new species. The bivalve assemblage changes from a "normal shale facies fauna" to a "restricted shale facies fauna" (Morris 1979, Pedersen 1986). The changes in the kerogen curve pattern could thus be due, in part, to a decrease in bioturbation as a result of the dramatic decrease in benthonic fauna. Intensive bioturbation in the lower part of the sequence (Pedersen 1986) probably homogenized the organic matter. Larger changes in the kerogen assemblages would, however, be expected to be preserved despite intensive bioturbation. The kerogen assemblage in the lower part of the sequence thus seems to have been relatively constant. Abrupt and significant variations in the kerogen assemblages were recorded in the sequence with a restricted benthonic fauna, probably in part because of significantly reduced bioturbation. However, the full implications of this marked shift in kerogen assemblages is not clear.
Pedersen (1986) related the decrease in the benthonic fauna to a decrease in oxygen in the bottom waters, presumably in response to the Late Sinemurian-Early Pliensbachian sea-level rise (Hallam 1981). Such a decrease in oxygenation is not supported by the AmexOC-values.

The almost total absence of a benthonic fauna in the uppermost sample of the Fjerritslev Formation (F-III member) was suggested by Pedersen (1986) to indicate the initiation of the Early Toarcian anoxic event. Increases in AmexOC and in the relative abundance of marine palynomorphs, combined with increasing relative abundances of Spheripollenites and Corollina (Dybkjær 1988), support this suggestion.

\section{Correlation with eustatic sea-level changes}

Significant variation in lithology and in the kerogen assemblages, in the four boreholes, possibly resulted from "pulses" in the Early Jurassic sea-level rise, as shown in the sea-level curve of Hallam (1981) (see fig. 19).
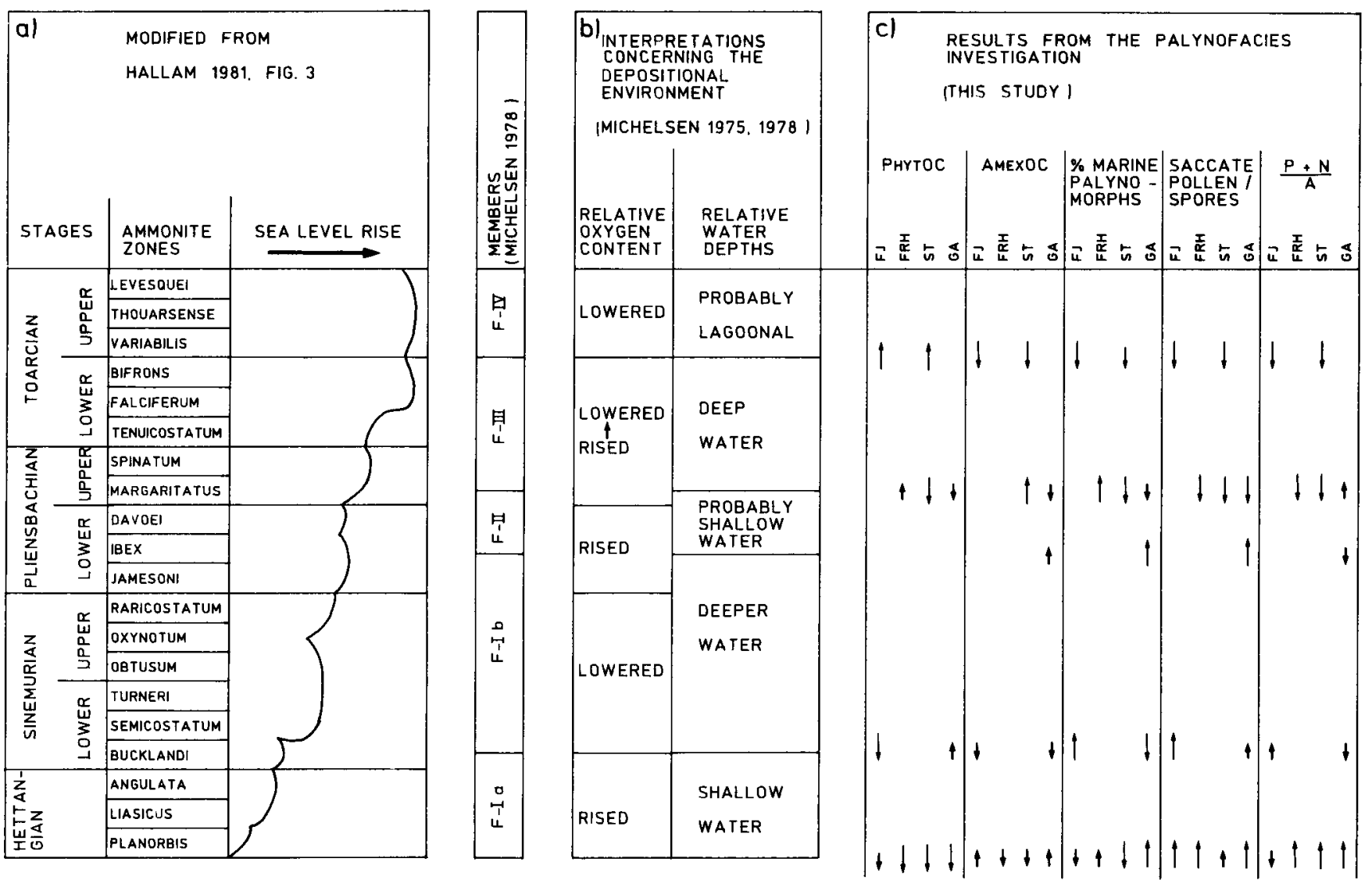

Fig. 19. Comparison of a) Hallam's (1981) sea-level curve, and b) Michelsen's (1975, 1978) interpretations of the depositional environment of the lithostratigraphical units, with c) the results from the palynofacies investigation presented here. The arrows in (c) indicate whether there is a tendency for the parameters to increase or decrease passing from one lithostratigraphic unit to the other; these are based on comparisons of the mean values for each unit. The exact numbers are presented in Appendix E. Where there is no arrow either one of the lithostratigraphic units are not represented (or not defined) in the borehole, or no core samples exist from the unit.

$\begin{array}{ll}1: \text { distinct rise } & 1 \text { : weak rise } \\ j \text { : distinct fall } & 1 \text { : weak fall }\end{array}$ 
The basal Hettangian phase of sea-level rise was probably responsible for the change in sedimentation from the Gassum Formation to the Fjerritslev Formation in the distal to central parts of the subbasin - the Fjerritslev-2, Gassum-1, and Stenlille-2 boreholes. The transition from the Gassum Formation to the Fjerritslev Formation in Frederikshavn-2 is, according to Pedersen (1986), correlatable with the Late Sinemurian-Early Pliensbachian phase of sea-level rise. However, the biostratigraphic data presented here indicates an Early Sinemurian age for this event.

The Late Sinemurian-Early Pliensbachian sea-level rise could explain the significant changes in the benthonic fauna and in the curve-patterns of the kerogen categories in the Gassum-1 borehole (see discussion above).

According to Pedersen (1986) the transition from the F-II to the F-III member can possibly be related to a Late Pliensbachian rise in sea-level; the variable degrees of oxygen-deficiency in the middle to upper part of the F-III member, and in the F-IV member can be related to the Early Toarcian sea-level rise.

Indications of the major "pulses" of Early Jurassic sealevel rise, in the Gassum-1 borehole, have been studied by Pedersen (1986) and Dybkjær (1988).

Based on the idea that the initial phases of smaller transgressions induce oxygen deficiency on the seafloor (Hallam \& Bradshaw 1979), Pedersen proposed a relationship between the above mentioned major change in the bottom fauna and the Late SinemurianEarly Pliensbachian phase of sea-level rise. Furthermore, it was suggested that the total absence of benthonic fossils in the uppermost sample referred to the Fjerritslev Formation, dated as Late Pliensbachian, could reflect the initiation of the Early Toarcian phase of sea-level rise.

Dybkjær (1988) investigated the palynomorph assemblages in the Lower Jurassic sequence in Gassum-1 and demonstrated a possible relationship between levels of maximum relative abundance of marine palynomorphs and the major "pulses" in sea-level rise during the Early Jurassic, as presented by Hallam (1981).

The relationship between the AmexOC-curve and the curve of marine versus terrestrial palynomorphs in Gassum-1 supports the correlation with Hallam's (1981) phases of sea-level rise.

\section{Geographical variation}

The four boreholes revealed some mutual differences in the kerogen assemblages that are probably related to their palaeogeographic situation within the Danish Subbasin.

A comparison of the composition of the organic matter from the four boreholes is given in fig. 20. In order to compare the results in this way, stage for stage, it has been necessary to make some assumptions concerning the age of some of the investigated samples. Sample Fj-11,c, from Fjerritslev-2, has been treated as being of Sinemurian age, and samples $\mathrm{Fj}-12, \mathrm{c}$ and $\mathrm{Fj}-13, \mathrm{c}$ as being of Pliensbachian age. Samples Frh-13,c and Frh-14,c, from Frederikshavn-2, have been assumed to be of Pliensbachian age while sample St-5,c from Stenlille-2, is regarded as the lowermost sample of Hettangian age. Furthermore, it should be noted that due to the sparse core coverage, samples within a broad stratigraphic interval are compared, e.g. samples from the Lower Pliensbachian in one borehole are compared with samples representing the Upper Pliensbachian from another borehole.

In the Hettangian stratigraphic interval, the mean values of the Gassum-1 borehole clearly indicate a more distal location than those of the Fjerritslev- 2 and Stenlille-2 boreholes, showing a lower PhytOC mean value, a higher mean ratio of saccate pollen/spore, and a higher mean value of $\%$ marine palynomorphs.

In the Sinemurian, the most significant differences are seen between the distally located Gassum-1 borehole and the most marginally situated borehole, Frederikshavn-2. Gassum-1 clearly shows a lower mean PhytOC value, a higher mean ratio of saccate pollen/ spores, and a significantly higher mean value of \% marine palynomorphs than Frederikshavn-2. A slightly higher mean AmexOC value was also recorded from Gassum-1. The mean values from the two other boreholes show trends inbetween the Gassum-1 and Frederikshavn-2.

Also in the Pliensbachian interval, the mean values of the Frederikshavn- 2 clearly reflect the marginal location of this borehole, compared to the others, showing the highest mean PhytOC values, the lowest ratio of saccate pollen/spores, and the lowest relative abundance of marine palynomorphs.

In the Toarcian interval the mean values in Frederikshavn- 2 continuously reflect a more marginal position than the Fjerritslev-2 and Stenlille- 2 boreholes, showing the highest mean PhytOC value and the lowest mean AmexOC value. The marginal position of Frederikshavn-2 is further reflected by the differences in the mean ratio of saccate pollen/spores and in the mean value of $\%$ marine palynomorphs compared to the Fjerritslev-2 borehole.

The palynomorph assemblages in the two samples representing the Toarcian in Stenlille-2 are, as mentioned earlier, totally dominated by a single species, here referred to Spheripollenites psilatus. The mean values based on palynomorphs (the ratio saccate pollen/spores, the ratio $(\mathrm{P}+\mathrm{N}) / \mathrm{A}$, and \% marine palynomorphs) are therefore not reliable and not comparable with the results from the other boreholes.

The mean values of the ratio (Polygonomorphitae + 


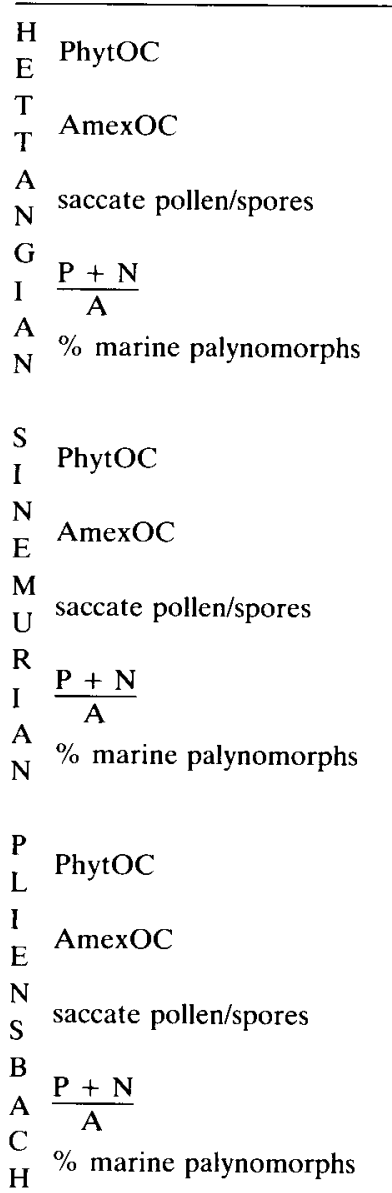

$$
\text { T PhytOC }
$$

AmexOC

A

C saccate pollen/spores

I $\frac{P+N}{A}$

$\mathrm{N} \%$ marine palynomorphs

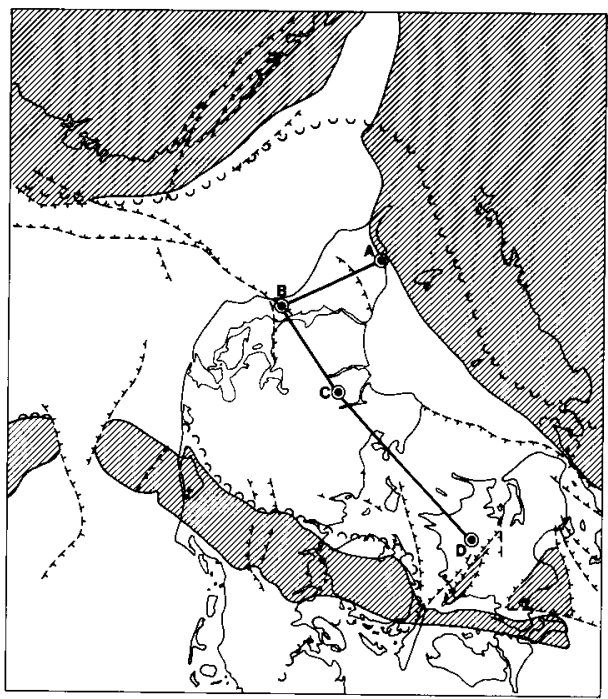

$0.97 \quad(n=1)$

$0.53(n=8)$

$0.75(n=15)$

$0.04 \quad(n=1)$

$0.05(n=8)$

$0.04 \quad(n=15)$

$0.27(\mathrm{n}=1)$

$0.80 \quad(\mathrm{n}=8)$

$0.30 \quad(n=14)$

$0.00 \quad(n=1)$

$0.23(n=8)$

$0.40 \quad(n=14)$

$7 \% \quad(n=1)$

$21 \% \quad(n=8)$

$11 \% \quad(n=14)$

$1.09 \quad(n=11)$

$0.67 \quad(n=7)$

$0.56 \quad(n=10)$

$0.64(n=1)$

$0.02(n=11)$

$0.01 \quad(n=7)$

$0.05 \quad(n=10)$

$0.00 \quad(n=1)$

$0.40 \quad(n=4)$

$0.56(n=4)$

$0.88 \quad(n=8)$

$0.13(n=1)$

$0.19(n=7)$

$0.02(n=4)$

$0.14(n=8)$

$0.67 \quad(n=1)$

$9 \% \quad(n=7)$

$10 \% \quad(n=4)$

$26 \% \quad(n=8)$

$7 \% \quad(n=1)$

$0.77(n=2)$

$0.58 \quad(n=2)$

$0.63(n=15)$

$0.41 \quad(n=4)$

$0.03(n=2)$

$0.01 \quad(n=2)$

$0.08 \quad(n=15)$

$0.05(n=4)$

$0.47(n=2)$

$1.47(\mathrm{n}=1)$

$1.08 \quad(n=10$

$1.15(\mathrm{n}=3)$

$0.30 \quad(n=2)$

$0.11 \quad(n=1)$

$0.09 \quad(n=10)$

$0.32(n=3)$

$10 \% \quad(n=2)$

$25 \% \quad(n=1)$

$20 \% \quad(n=10)$

$19 \% \quad(n=3)$

$0.66(n=8)$

$0.54 \quad(n=2)$

$0.14(n=2)$

$0.02(n=8)$

$0.27(n=2)$

$0.75(n=2)$

$0.43(n=5)$

$2.09 \quad(n=1)$

$0.32 \quad(n=5)$

$0.16(n=1)$

$0.00(\mathrm{n}=2)$

$0.09(\mathrm{n}=2)$

$16 \% \quad(n=5)$

$24 \% \quad(\mathrm{n}=1)$

Fig. 20. This figure shows the overall differences in the kerogen assemblages from the four boreholes in relation to their location in the Danish Subbasin. The mean value for each stage is presented together with the number of samples responsible for the mean value $(n)$. The Hettangian has not been investigated in the Frederikshavn-2 borehole, as these deposits are referred to the Gassum Formation.

No deposits of Toarcian age were recorded in the Gassum-1 borehole.

Fig. 21. Thermal Alteration Index (T.A.I.) related to depth. The recorded variations for each sample and the mean value are indicated. The boundary between immature and mature is also indicated. 
THE FJERRITSLEV NO. 2 BOREHOLE

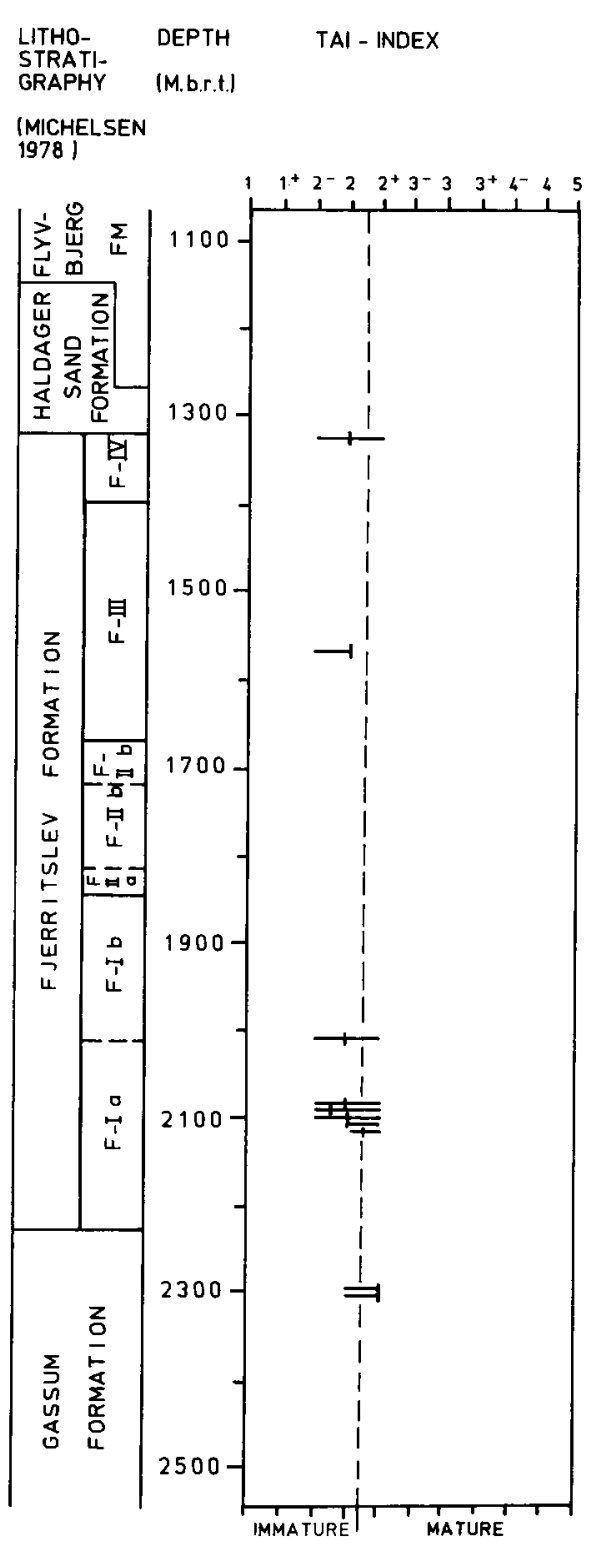

THE FREDERIKSHAVN No. 2 BOREHOLE

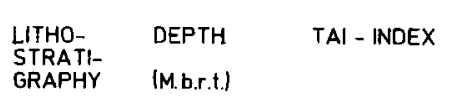

(MICHELSEN
1978 )

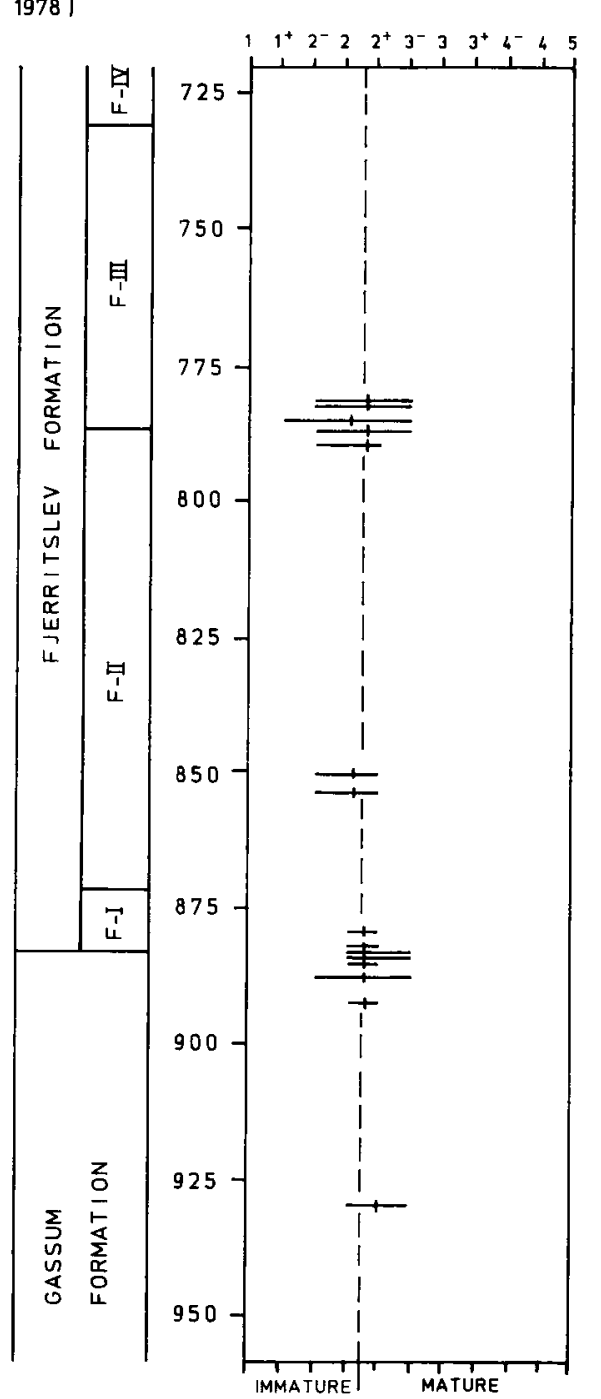

THE STENLILLE NO. 2 BOREHOLE

LITHO- DEPTH TAI - INDEX GRAPHY (M.b.r.t)

IFRANDSEN

STIUDY THS

STUDY 1 |

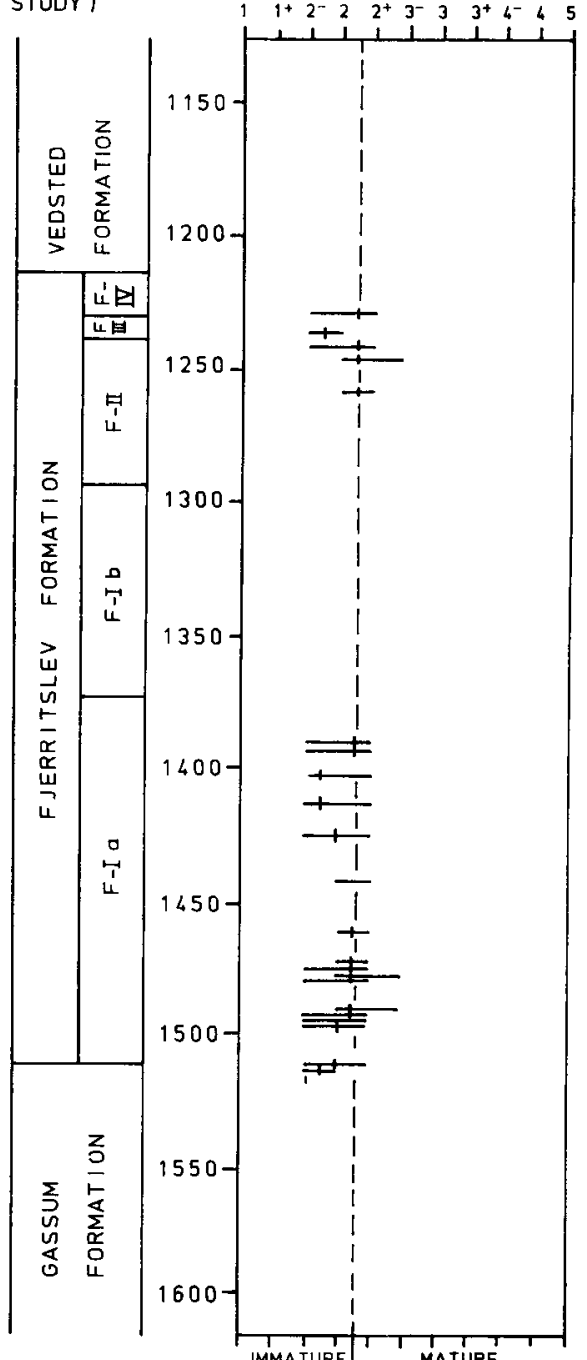

THE GASSUM No. 1 BOREHOLE

LITHO- DEPTH TAI - INDEX STRATL-
GRAPHY (M.b.r.t)

IMICHELSEN

1978: PEDER-

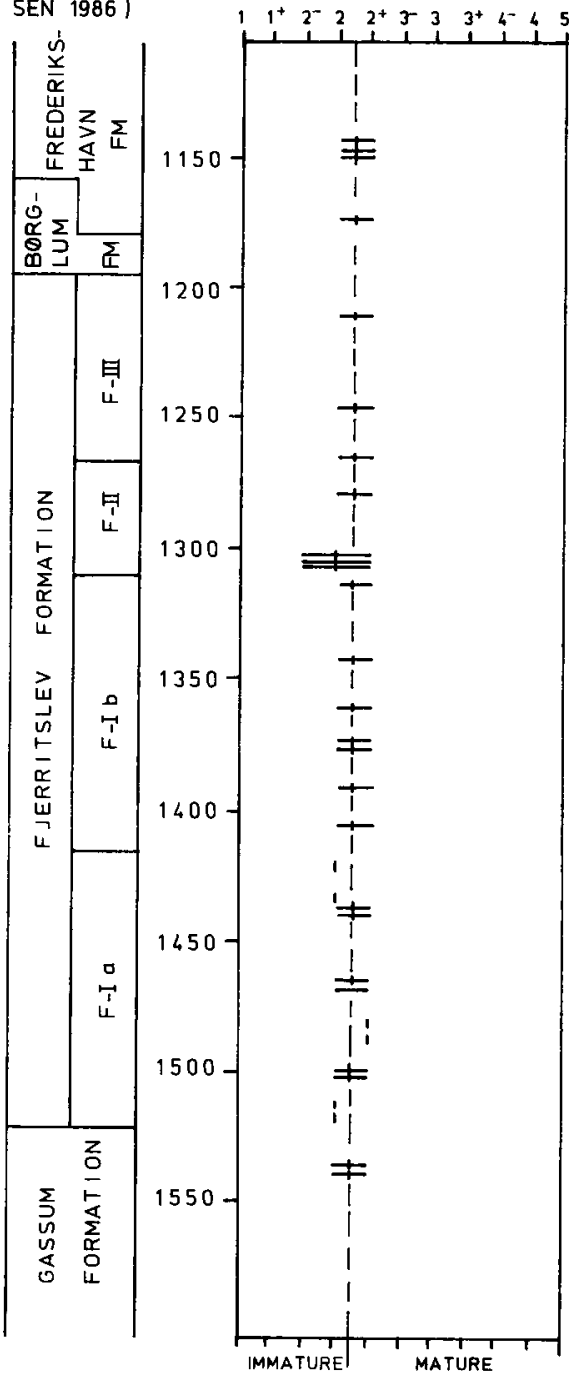


Netromorphitae)/Acanthomorphitae generally show the trends opposite to those expected. Theoretically a high ratio indicates deposition in a relatively deepwater environment, while low ratios should indicate a shallow-water depositional environment. Here the mean values from Frederikshavn- 2 are generally the highest. The usefulness of this ratio as an indication of water-depths should thus be investigated further.

With the exception of the ratio mentioned above, it can be concluded that the differences in the kerogen assemblages from the four boreholes are useful indication of their relative locations in the basin.

\section{Amount, type and maturation of organic matter}

According to Thomsen et al. (1987), the Fjerritslev Formation is the only Mesozoic sequence in the Norwegian-Danish Basin that qualifies as a potential source for oil.

A Total Organic Carbon (T.O.C.) value of $0.5 \%$ is the absolute minimum value for a marine shale to represent a potential source rock. Furthermore, the composition of the organic matter is critical for the hydrocarbon potential. The main distinction is made between terrestrial (non-aquatic) kerogen particles and particles derived from aquatic organisms. Kerogen comprising a large amount of terrestrial plant debris is generally only capable of generating a small amount of oil compared with kerogen made of marine or limnic organic matter. The terrestrially-derived kerogen could, however, provide a good source for hydrocarbon gas at greater depths (Tissot \& Welte 1984).

The highest recorded T.O.C. values are from samples referred to the Gassum Formation where they vary from $0.9 \%$ to $4.7 \%$ (see Appendices A-D and figs 12 , $14,16 \& 18$ ); the maximum values were from the Frederikshavn-2 borehole. The kerogen assemblages in these samples are strongly dominated by terrestrial material. T.O.C. values in the Fjerritslev Formation vary between $0.4 \%$ and $1.9 \%$; the highest values are from the F-III and F-IV members.

The kerogen assemblages in the F-Ia, F-Ib, and F-II members are strongly dominated by terrestrially-derived kerogen, especially brown wood. The composition of the kerogen assemblages in the F-III member varies a great deal from borehole to borehole, but shows a distinct decrease in the relative abundance of brown wood and a concurrent increase in A.O.M. and marine palynomorphs compared to the F-Ia, F-Ib, and F-II members. The kerogen assemblages in the F-IV member are dominated by terrestrially-derived particles, but the relative abundance of A.O.M. is higher than in the F-Ia, F-Ib, and F-II members.

The mean T.A.I.-values for each sample varies between 2- and 2+ (fig. 21). Maturity shows an overall increase with depth in Fjerritslev-2 and Frederikshavn-2, whereas no trends were recognized in Stenlille-2 and Gassum-1. Thomsen et al. (1983) recorded a general increase in rank with depth in all investigated boreholes, including Fjerritslev-2, Frederikshavn-1 and Gassum-1, although their investigation encompassed the full sequence from Rhaetian to Lower Cretaceous.

It can be concluded that the Fjerritslev Formation does not generally represent a potential source rock for oil. A few levels in the F-III member, however, show the characteristics of a fair to good source rock. The T.A.I. values indicate that the organic matter is generally immature, or only at the earliest stage of maturity. These results correspond very well with results from previous investigations (see p. 12-13). 


\section{Acknowledgements}

The Geological Survey of Denmark and Dansk Olie \& Gasproduktion A/S are thanked for providing the core material, and for permission to publish the results. The study constitutes the bulk of a Ph.D. thesis prepared under the supervision of Kaj Raunsgaard Pedersen, who is thanked for encouragement and helpful discussion. Several persons provided technical assistance, especially Bitten Larsen, Mette Dybdal, Lis Olesen and Søren Bo Andersen from the Geological Institute, University of Aarhus, and Helle Zetterwall, from the
Geological Survey of Denmark. Elly Andersen kindly helped with the plates. An early draft was read by Richard Tyson and Roger M. Konieczny who suggested many improvements. Stefan Piasecki and Olaf Michelsen reviewed the manuscript and made further helpful suggestions. Richard Wilson, Hanne B. Sørensen and Jon Ineson kindly corrected the English.

I am most grateful to all those mentioned above, and to others not mentioned by name who assisted me with discussion, information and encouragement. 
Alberti, G., 1961: Zur Kenntnis mesozoisher und alttertiärer Dinoflagellaten und Hysterichosphaerideen von Nord- und Mitteldeutschland, sowie einigen anderen europäischen Gebieten. Palaeontographica, Abt. A 116, 1-58.

Balme, B.E., 1957: Spores and pollen grains from the Mesozoic of Western Australia. Coal Res. C.S.I.R.O. Ref. T.C. 25, 1-48.

Balme, B.E. \& Segroves, K.L., 1966: Peltacystia gen. nov.: a microfossil of uncertain affinities from the Permian of Western Australia. J. Proc. R. Soc. West. Aust. 49, 26-31.

Batten, D.J., 1973: Use of palynologic assemblage-types in Wealden correlation. Palaeontology 16(1), 1-40.

Batten, D.J., 1974: Wealden Palaeoecology from the Distribution of Plant Fossils. Proc. Geol. Ass. 85(4), 433-458.

Batten, D.J., 1978: Early Cretaceous to Middle Jurassic miospores and palynofacies of the Northwest European continental shelf. In: Thusu, B.(ed.): Distribution of biostratigraphically diagnostic dinoflagellate cysts and miospores from N-W European continental shelf and adjacent areas. Cont. Shelf Inst. Publ. 100, 97-101.

Batten, D.J., 1980: Use of transmitted light microscopy of sedimentary organic matter for evaluation of hydrocarbon source potential. Proc. IV Int. Palynol. Conf. Lucknow (1976-1977) 2, 589594.

Batten, D.J., 1981: Palynofacies, organic maturation and source potential for petroleum. In: Brooks, J.: Organic maturation studies and fossil fuel exploration. Academic Press, London, 201-223.

Batten, D.J., 1982: Palynofacies, palaeoenvironments and petroleum. J. micropalaeontol. 1, 107-114.

Batten, D.J., 1983: Identification of amorphous sedimentary organic matter by transmitted light microscopy. In: Brooks, J. (ed.): Petroleum geochemistry and exploration of Europe. Geol. Soc. London, Blackwell Scient. Publ. 11, 275-287.

Batten, D.J. \& MacLellan, A.M., 1984: Paleoenvironmental significance of the conifer family Cheirolepidiaceae in the Cretaceous of Portugal. In: Reif, W.E. \& Westphal, F. (eds.): Third Symposium on Mesozoic Terrestrial Ecosystems. Short Papers, ATTEMPTO Verlag, 7-12.

Below, R., 1987: Evolution und systematik von dinoflagellatenzysten aus der ordning Peridiniales. I. Allgemeine grundlagen und subfamilie Rhaetogonyaulacoideae (Familie Peridiniaceae). Palaeontographica, Abt. B 205(1-6), 1-164.

Berry, W., 1937: Spores from the Pennington Coal, Rhea County, Tennessee. Am. Midland Naturalist 18, 155-160. In: Catalog of Fossil Spores and Pollen, vol. 7 (1959), 1-14.

Bertelsen, F., 1978: The Upper Triassic-Lower Jurassic Vinding and Gassum Formations of the Norwegian-Danish Basin. D.G.U. Ser. B $3.26 \mathrm{pp}$.

Bertelsen, F., 1979: Palynological investigations of the Triassic Jurassic section of the Hobro No. 1 borehole. In: Michelsen, O.: Report on the Jurassic of the Hobro No. 1 and Voldum No. 1 borings, Denmark. D.G.U., Årbog 1978, 141-149.

Bharadwaj, D.C. \& Singh, H.P., 1964: An Upper Triassic Miospore Assemblage from the Coals of Lunz, Austria. Palaeobotanist 12 (1), 28-44.

Boalch, G.T. \& Parke, M., 1971: The Prasinophycean genera (Chlorophyta) possibly related to fơssil genera, in particular the genus Tasmanites. In: Farinacci, A. (ed.): Proceedings of the Second Planktonic Conference, Roma 1970, 99-105.

Bolchovitina, N.A., 1953: Characteristic spore-pollen assemblages from the Cretaceous sediments of the Interior regions of the U.S.S.R. Akad. Nauk. S.S.S.R., Trudy Inst. Geol. Nauk 145(61), 1-148 (in russian).

Bolchovitina, N.A., 1956: Atlas of spores and pollen in Jurassic and Lower Cretaceous of the Viliusk Basin. Akad. Nauk S.S.S.R., Trudy Inst. Geol. 2. 185 pp. (in russian).
Bolchovitina, N.A., 1961: Fossil and recent Spores of the family Schizaeaceae. Akad. Nauk. S.S.S.R., Trudy Geol. Inst., 40. 175 pp. (in russian).

Bolchovitina, N.A., 1966: The fossil spores of the ferns of the family Gleicheniaceae (taxonomy and distribution). In: Neishtadt (ed.): The importance of palynological analysis for stratigraphic and paleofloristic investigations. Akad. Nauk S.S.S.R., Trudy Geol. Inst., 65-75 (in russian).

Boulter, M.C. \& Riddick, A., 1986: Classification and analysis of palynodebris from the Palaeocene sediments of the Forties Field. Sedimentology 33, 871-886.

Brenner, G.J., 1963: The spores and pollen of the Potomac Group of Maryland. Maryland Dept. Geol., Mines, and Water Res., Bull. 27. $215 \mathrm{pp}$.

Brenner, W., 1986: Bemerkungen zur Palynostratigraphie der RhätLias-Grenze in SW-Deutschland. N. Jb. Geol. Paläont. Abh. 173 (2), 131-166.

Brooks, J., (ed.) 1981: Organic Maturation Studies and Fossil Fuel Exploration. Academic Press, London. $441 \mathrm{pp}$

Brush, G.S. \& Brush, L.M., 1972: Transport of pollen in a sedimentladen channel: A laboratory study. Am. J. Sci. 272, 359-381.

Burgess, J.D., 1974: Microscopic Examination of Kerogen (Dispersed Organic Matter) in Petroleum Exploration. In: Dutcher, R.R., Hacquebard, P.A., Schopf, J.M. \& Simon, J.A. (eds.) Carbonaceous Materials as Indicators of Metamorphism. Geol Soc. America, Spec. Paper 153, 19-30.

Chaloner, W.G., 1968: The palaeoecology of fossil spores. In: Drake, E.T. (ed.): Evolution and Environment. Yale Univ. Press, New Haven, London, 125-138.

Clark, R.L., 1983: Fire history from fossil charcoal in lake and swamp sediments. 197 pp. Australian National Univ., Canberra (unpublished Ph.D. thesis).

Combaz, A., 1964: Les palynofacies. Rev. Micropaleontol. Paris 7 , 205-218.

Combaz, A., 1975: Essai de classification des roches carbonées et des constituants, organiques des roches sédimentaires. In: Alpern, B. (ed.): Pétrographie de la matière organique des sédiments, relations avec la paléotempérature et le potentiel pétrolier. Coll. Int. Sept. 1973. Editions du C.N.R.S., Paris, 93-102.

Cookson, I.C., 1947: Plant Microfossils from the Lignites of Kerguelen Archipelago. B.A.N.Z. Antarc. Res. Exped. 1929-1931, Rep. Ser.A. 2(8), 127-142

Cookson, I.C., 1953: Difference in microspore composition of some samples from a bore at Comaum, South Australia. Aust. Jour. Bot. 1(3), 462-473.

Cookson, I.C. \& Dettmann, M.E., 1959: On Schizosporis, a new formgenus from Australian Cretaceous deposits. Micropaleontology 5(2), 213-216.

Cookson, I.C. \& Eisenack, A., 1958: Microplankton from Australian and New Guinea Upper Mesozoic sediments. Proc. Roy. Soc. Victoria 70, 19-79.

Cornet, B. \& Traverse, A., 1975: Palynological contributions to the chronology and stratigraphy of the Hartford Basin in Connecticut and Massachusetts. Geoscience and Man 11, 1-33.

Correia, M., 1967: Relations possible entre l'état de conservation des éléments figures de la matiere organique (microfossiles, palynoplantologiques) et l'existence de gisements d'hydrocarbures. Rev. Inst. Francais Petrole, 22, 1285-1306.

Couper, R.A., 1953: Upper Mesozoic and Cainozoic spores and pollen grains from New Zealand. New Zealand Geol. Surv., Paleontol. Bull. 22, 1-77.

Couper, R.A., 1958: British Mesozoic microspores and pollen grains. A systematic and stratigraphic study. Palaeontographica, Abt. B 103(4-6), 75-179. 
Cross, A.T., Thompson, G.G. \& Zaitzeff, J.B., 1966: Source and distribution of palynomorphs in bottom sediments, southern part of Gulf of California. Marine Geol. 4, 467-524.

Dale, B., 1983: Dinoflagellate resting cysts: "benthic plankton". In: Fryxell, G.A. (ed.): Survival strategies of the algae. Cambridge Univ. Press, 69-136.

Damtoft, K., Andersen C. \& Thomsen, E., 1987: Prospectivity and hydrocarbon plays of the Danish Central Trough. In: Brooks, J. \& Glennie, K. (eds.): Petroleum Geology of North West Europe. Graham \& Trotman, 40.3-417

Danzé-Corsin, P. \& Laveine, J.P., 1963: Microflore. In: Briche, P., Danzé-Corsin, P. \& Laveine, J.P.: Flore infraliassique du Boullonnais (Macro- et Microflore). Mém. Soc. Géol. Nord. 13, 57-109.

Davey, R.J., 1969: Non-calcareous microplankton from the Cenomanian of England, northern France and North America, Part I. Brit. Mus. (Nat. Hist.) Bull. Geol. 17, 103-180.

Davey, R.J., 1970: Non-calcareous microplankton from the Cenomanian of England, northern France and North America. Part II. Brit. Mus. (Nat. Hist.) Bull. Geol. 18(8), 335-397.

Davey, R.J., 1971: Palynology and palaeo-environmental studies, with special reference to the continental-shelf sediments of South Africa. In: Farinacci, A. (ed.): Proceedings of the Second Plank tonic Conference, Roma 1970, 331-347. Davey, R.J. \& Rogers, J., 1975: Palynomorph distribution in recent offshore sediments along two traverses off South West Africa. Marine Geol. 18, 213-225.

Davey, R.J. \& Verdier, J.P., 1971: An investigation of microplankton assemblages from the Albian of the Paris Basin. Verhand Koninklijke Nederlandsche Akad. Wetensch., Afd. Natuurkunde, I. rk., 26, 1-58.

Davey, R.J. \& Verdier, J.P., 1976: A review of certain nontabulate Cretaceous hystrichospherid dinocysts. Rev. Palaeobot. Palynol. 22, 307-335.

Davey, R.J. \& Williams, G.L., 1966: The genus Hystrichosphaeridium and its allies. In: Davey, R.J., Downie, C., Sarjeant, W.A.S \& Williams, G.L.: Studies on Mesozoic and Cainozoic dinoflagellate cysts. Brit.Mus. (Nat. Hist.) Bull. Geol. 3, 53-106.

de Jersey, N.J., 1962: Triassic spores and pollen grains from the Ipswich Coalfield. Publ. geol. Surv. Queensland 307. 18 pp

Déak, H.M., 1962: Deux nouveaux genres de spore de la série d'argiles et de marnes aptiennes. Földtani Közlöng, Budapest, 92 , 230-235.

Deflandre, G., 1938: Sur le microplancton des mers jurassiques, conservé à l'état de matière organique dans les marnes des Villerssur-Mer. Compter rendus de l'Académie des sciences, Paris 206 , 687-689.

Deflandre, G., 1954: Systématique des Hystrichosphaeridés: sur l'acception du genre Cymatiosphaera O. Wetzel. C.R. Somm. Séanc. Soc. Géol. Fr., 257-258.

Deflandre, G. \& Cookson, I.C., 1955: Fossil microplankton from Australian Late Mesozoic and Tertiary sediments. Austral. Jour. Mar. Freshw. Res. 6, 242-313.

Delcourt, A.F., Dettmann, M.E. \& Hughes, N.F., 1963: Revision of some Lower Cretaceous microspores from Belgium. Palaeontology 6, 282-292.

Delcourt, A.F. \& Sprumont, G., 1955: Les spores et grains de pollen du Wealden du Hainaut. Bull. Soc. belge. Géol. Paléont. Hydrol. 4(5). $73 \mathrm{pp}$

Dettmann, M.E., 1963: Upper Mesozoic microfloras from South Eastern Australia. Proc. Roy. Soc. Victoria. 77(1), 1-148.

Dev, S., 1961: The fossil flora of the Jabalpur Series - 3. Spores and pollen grains. Palaeobotanist 8(1-2), 43-56.

Diver, W.L. \& Peat, C.J., 1979: On the interpretation and classification of Precambrian organic-walled microfossils. Geology 7, 401404

Dorning, K.J., 1981: Silurian acritarchs from the type Wenlock and Ludlow of Shropshire, England. Rev. Palaeobot. Palynol. 34, 175 203

Dow, W.G., 1977: Kerogen studies and geological interpretations. J Geochem. Expl. 7, 79-99.

Downie, C., Evitt, W.R. \& Sarjeant, W.A.S., 1963: Dinoflagellates, hystrichospheres and the classification of the acritarchs. Stanford Univ. Publ. Geol. Sci. 7(3), 1-16.

Drugg, W.S., 1978: Some Jurassic dinoflagellate cysts from England France and Germany. Palaeontographica, Abt. B 168 (1-3), $61-79$.
Dybkjær, K., 1988: Palynological zonation and stratigraphy of the Jurassic section in the Gassum No. 1-borehole, Denmark. D.G.U. Ser. A $21.73 \mathrm{pp}$.

Dörhöfer, G., 1977: Palynologie und Stratigraphie der BückebergFormation (Berriasium - Valanginium) in der Hilsmulde (NWDeutschland). Geol. Jahrb. A 42, 1-122.

Dörhöfer, G., 1979: Distribution and Stratigraphic utility of Oxfordian to Valanginian Miospores in Europe and North America. AASP Contributions Series 5B, 101-132.

Döring, H., 1965: Dic sporenpaläcontologische Gliederung des Wealden in Westmecklenburg (Struktur Werle). Geologie, Berlin 14(47), 1-118.

Döring, H., 1966: Die sporenstratigraphische Gliederung der Unterkreide im nördlichen Mitteleuropa. In: Döring, H., Krutzsch, W., Mai, D.H. \& Schulz, E.: Erläuterungen zu den sporenstratigraphischen Tabellen vom Zechstein bis zum Oligozän. Abh. zentr. geol. Inst. Berlin 8, 61-78.

Döring, H., Krutzsch, W., Mai, D.H. \& Schulz, E., 1963: Retitriletes. In: Krutzsch, W., 1963: Atlas der mittel- und jungtertiären dispersen Sporen- und Pollen- sowie der Mikroplanktonformen des Nördlichen Mitteleuropas. Lief. II VEB Deutscher Verlag der Wissenschaften, Berlin, 8-18.

Döring, H., Krutzsch, W., Mai, D.H. \& Schulz, E., 1966: Erläuterungen zu den sporenstratigraphischen Tabellen vom Zechstein bis zum Oligozän. Abh. zentr. geol. Inst. Berlin 8. $149 \mathrm{pp}$.

Döring, H., Krutzsch, W., Schulz, E. \& Timmermann, E., 1966: Über einige neue Subformgenera der Sporengattung Stereisporites TH. und PF. aus dem Mesozoikum und Alttertiär Mitteleuropas. Geologie, Berlin 15(55), 72-89

Ehrenberg, C.G., 1838: Über das Massenverhältniss der jetzt lebenden Kiesel-Infusorien und über ein neues Infusorien Conglomerat als Polirschiefer von Jastraba in Ungarn. Abhand. Preus. Akad. Wissensch., 1836, 109-135

Eisenack, A., 1958: Tasmanites Newton und Leiosphaeridia n.g. als Gattungen der Hystrichosphaeridea. Palaeontographica, Abt. A $110,1-19$.

Eisenack, A., 1972: Kritische Bemerkung zur Gattung Pterospermopsis (Chlorophyta, Prasinophyceae). N. Jb. Geol. Paläont. Monatsh. 10, 596-601.

Erdtman, G., 1948: Did Dicotyledonous Plants exist in Early Jurassic Times? Geol. Fören. Stockh. Förh. 70, 265-271.

Erkmen, U. \& Sarjeant, W.A.S., 1980: Dinoflagellate cysts, acritarchs and tasmanitids from the uppermost Callovian of England and Scotland: with a reconsideration of the "Xanthidium pilosum" problem. Geobios 13, 45-99.

Evitt, W.R., 1961 a: Dapcodinium priscum n. gen., n. sp., a Dinoflagellate from the Lower Lias of Denmark. J. Palaeont. 35(5), 996-1002.

Evitt, W.R., 1961b: The dinoflagellate Nannoceratopsis Deflandre: morphology, affinities and infraspecific variability. Micropaleontology $7(3), 305-317$.

Fenchel, T.M. \& Jørgensen, B.B., 1977: Detritus food chains of aquatic ecosystems: the role of bacteria. In: Alexander, M. (ed.): Advances in Microbial Ecology 1. Plenum Press, New York, 1-58.

Filatoff, J., 1975: Jurassic Palynology of the Perth Basin, Western Australia. Palaeontographica, Abt. B 154(1-4), 1-113.

Filatoff, J. \& Price, P.L., 1988: A pteridacean spore lineage in the Australian Mesozoic. Mem. Ass. Australas. Palaeontols 5, 89-124.

Fisher, M.J., 1980: Kerogen distribution and depositional environments in the Middle Jurassic of Yorkshire, U.K. Proc. IV. Int. Palynol. Conf. Lucknow (1976-77) 2, 574-580.

Fisher, M.J. \& Hancock, N.J., 1985: The Scalby Formation (Middle Jurassic, Ravenscar Group) of Yorkshire: reassesment of age and depositional environment. Proc. Yorkshire Geol. Soc. 45(4), 293 298.

Frandsen, N., 1988: Stenlille Wells. Sedimentology of the Gassum Formation and the Lower Fjerritslev Formation. 22 pp. Dansk Olie og Gasprod. A/S (unpublished report)

Frebold, H., 1948: The Stratigraphical Subdivision of the Lower Cretaceous and the Jurassic in Gassum Well No. 1. (Based on Megafossils). 7 pp. DapCo (unpublished report).

Gregersen, A. \& Sorgenfrei, T., 1951: Efterforskningsarbejdet i Danmarks dybere undergrund. Meddr. dansk geol. Foren. 12, $141-151$

Groot, J.J., 1966: Some observations on pollen grains in suspension in the estuary of the Delaware River. Marine Geol. 4, 409-416. 
Groot, J.J. \& Penny, J.S., 1960: Plant microfossils and age of nonmarine Cretaceous sediments of Maryland and Delaware. Micropaleontology 6(2), 225-237.

Guy, D.J.E., 1971: Palynological investigations in the Middle Jurassic of the Vilhelmsfält boring, southern Sweden. Publ. Inst. Min Palaeont. Quatern. Geol. Lunds Univ. 168. 104 pp.

Guy-Ohlson, D., 1986: Jurassic palynology of the Vilhelmsfält Bore No. 1, Scania, Sweden, Toarcian - Aalenian. Sec. Palaeobot., Swedish Mus. Nat. Hist., Stockholm. 127 pp.

Guy-Ohlson, D., 1988: The use of dispersed palynomorphs referable to the formgenus Chasmatosporites (Nilsson) Pocock et Jansonius in Jurassic biostratigraphy. IV Congr. Argentino de paleontol. y bioestratigr., Nov. 1986, ACTAS 3, Mendoza 1988.

Guy-Ohlson, D., Lindqvist, B. \& Norling, E., 1987: Reworked Carboniferous spores in Swedish Mesozoic sediments. Geol. Fören. Stockh. Förh. 109(4), 295-306

Habib, D., 1979: Sedimentology of palynomorphs and palynodebris in Cretaceous carbonaceous facies south of Vigo Seamount. Initia Rep. D.S.D.P. 47(2), 451-465.

Hallam, A., 1963: Eustatic control of major cyclic changes in Jurassic sedimentation. Geol. Mag. 100(5), 444-450.

Hallam, A., 1967: An environmental study of the Upper Domerian and Lower Toarcian in Great Britain. Phil. Trans. Roy. Soc. Lond. 252B, 393-445

Hallam, A., 1978: Eustatic cycles in the Jurassic. Palaeogeogr. Palaeoclimatol. Palaeoecol. 23, 1-32.

Hallam, A., 1981: A revised sea-level curve for the early Jurassic. Jl. geol. Soc. London 138(6), 735-743.

Hallam, A., 1985: A review of Mesozoic climates. Jl. geol. Soc. London $142,433-445$.

Hallam, A., 1987: Radiations and extinctions in relation to environmental change in the marine Lower Jurassic of northwest Europe. Paleobiology 13(2), 152-168.

Hallam, A. \& Bradshaw, M.J., 1979: Bituminous shales and oolitic ironstones as indicators of transgressions and regressions. Jl. geol. Soc. London 136, 157-164.

Hancock, N.J. \& Fisher, M.J., 1981: Middle Jurassic North Sea Deltas with particular reference to Yorkshire. Petrol. Geol. Continental Shelf N.W. Europe, 186-195.

Hansen, J.M., 1981: Stenlille No. 1. Palynostratigraphy of the Base Chalk to the Base Gassum Fm. (with remarks on the palynofacies). 6 pp. D.G.U. (unpublished report).

Harland, R., Morbey, S.J. \& Sarjeant, W.A.S., 1975: A revision of the Triassic to lowest Jurassic dinoflagellate Rhaetogonyaulax. Palaeontology 18(4), 847-864.

Heilmann-Clausen, C., 1987: Lower Cretaceous dinoflagellate biostratigraphy in the Danish Central Trough. D.G.U. Ser. A 17. 89 pp.

Herngren, G.F.W. \& de Boer, K.F., 1974: Palynology of Rhaetian, Liassic and Dogger strata in eastern Netherlands. Geol. en Mijnbouw 53(6), 343-368.

Herring, J., 1985: Charcoal fluxes into sediments of the North Pacific Ocean: The Cenozoic record of burning. In: Sundquist, E.T. \& Broecker, W.S. (eds.): The Carbon Cycle and Atmospheric $\mathrm{CO}^{2}$ : Natural Variations Archean to present. Geophys. Monogr. 32, $419-442$.

Heusser, L., 1978: Spores and pollen in the marine realm. In: Haq, B.U. \& Boersma, A. (eds.): Introduction to marine micropaleontology. Elsevier North-Holland Inc., New York, 327-339.

Heusser, L., 1983: Pollen distribution in the bottom sediments of the western North Atlantic Ocean. Marine Micropal. 8, 77-88

Heusser, L.E., 1988: Pollen distribution in marine sediments on the continental margin off northern California. Marine Geol. 80, 131147.

Heusser, L.E. \& Balsam, W.L., 1977: Pollen distribution in the Northeast Pacific Ocean. Quatenary Research 7(1), 45-62.

Hiltman, W., 1967: Über die Sporenfuhrung des Kernprofils der Bohrung Contern FG11 (Unterer Lias, Luxemburg). Publs. Serv. géol. Luxembourg 17, 137-206.

Hoelstad, T., 1985: Palynology of the uppermost Lower to Middle Jurassic strata on Bornholm, Denmark. Bull. geol. Soc. Denmark 34, 111-132

Horst, U., 1943: Mikrostratigraphischer Beitrag zum Vergleich des Namur von West-Oberschlesien und Märisch-Ostrau. Die Megaund Mikrosporen der hauptsächlichen Flöze beider Reviere. Diss. Techn. Hochsch. Berlin.
Hughes, N.F. \& Moody-Stuart, J.C., 1967: Palynological facies and correlation in the English Wealden. Rev. Palaeobot. Palynol. 1, 259-268.

Johnson, C.D. \& Hills, L.V., 1973: Microplankton zones of the Savik Formation (Jurassic), Axel Heiberg and Ellesmere Islands, district of Franklin. Bull. Can. Petr. Geol. 21(2), 178-218.

Kedves, M. \& Simoncsics, P., 1964: Microstratigraphy of the carbonate manganese ore layers of the shaft III of Urkút on the basis of palynological investigations. Acta Min. Pet. 16(2), 3-48.

Kemp, E., 1970: Aptian and Albian miospores from southern England. Palaeontographica, Abt. B 131(1-4), 73-143.

Klaus, W., 1960: Sporen der kernischen Stuffe der ostalpinen Trias Jb. Geol. Bundesanst. 5, 107-183.

Koreneva, E.N., 1964: Spores and pollen from bottom sediments in the western part of the Pacific Ocean. Trudy Akad. Nauk S.S.S.R. 22, 221-251 (in russian)

Krutzsch, W., 1955: Über einige liassische und angiospermide Sporomorphen. Geologie, Berlin 4(1), 65-76.

Krutzsch, W., 1959: Mikropaläontologische (sporenpaläontologische) Untersuchungen in der Braunkohle des Geiseltales. Geologie, Berlin 8(21-22). 425 pp.

Krutzsch, W., 1963: Atlas der mittel- und jungtertiären dispersen Sporen- und Pollen- sowie der Mikroplanktonformen des Nördlichen Mitteleuropas. Lief. II, III. VEB Deutscher Verlag der Wissenschaften, Berlin. 141pp; 128 pp.

Larsen, G., 1966: Rhaetic-Jurassic-Lower Cretaceous Sediments in the Danish Embayment (A Heavy-Mineral Study). Danm. geol. Unders. II Rakke 91. 127 pp.

Leschik, G., 1955: Die Keuper flora von Neuewelt bei Basel. II. Die Iso- und Mikrosporen. Schw. Palaeontol. Abh. 72, 1-70.

Lindgreen, H. \& Thomsen, E., 1982: Investigations on the source rock potential of the Danish onshore area. 91 pp. D.G.U. (unpublished report).

Loeblich, A.R. Jr., 1970: Morphology, ultrastructure and distribution of Paleozoic acritarchs. In: Yochelsen, E.L. (ed.): Second North American Paleontological Convention, Chicago 1969. Proc., 705-788.

Loeblich, A.R. Jr. \& Loeblich, A.R. III, 1966: Index to the genera, subgenera, and sections of the Pyrrhophyta. Stud. Trop. Oceanogr., Miami, no.3.

Loeblich, A.R. Jr. \& Loeblich, A.R. III, 1968: Index to the genera, subgenera, and sections of the Pyrrhophyta, II; J. Paleont. 42, 210-213.

Luber, A.A. \& Waltz, I.E., 1938: Classification and stratigraphical value of spores of some Carboniferous coal deposits in the U.S.S.R. Trans. Central Geol. Prosp. Inst. 105, 1-45 (in russian). Lund, J.J., 1977: Rhaetic to Lower Liassic palynology of the onshore south-eastern North Sea Basin. Danm. geol. Unders. II Række 109. $130 \mathrm{pp}$.

Lund, J.J. \& Ecke, H.-H., 1988: Dinoflagellate cyst stratigraphy applied to the Middle to Late Jurassic of the Regensburg Passau area, Bavaria. Bull. Centres Rech. Explor.-Prod. Elf Aquitaine 12(1), 345-359.

Lund, J.J. \& Pedersen, K.R., 1985: Palynology of the marine Jurassic formations in the Vardekløft ravine, Jameson Land, East Greenland. Bull. geol. Soc. Denmark 33(3-4), 371-399.

Lundblad, B., 1954: Contributions to the geological history of the Hepaticae. Fossil Marchantiales from the Rhaetic-Liassic coalmines of Skromberga (prov. of Scania), Sweden. Sv. Bot. Tidskr. 48(2), 381-417.

Maljavkina, V.S., 1949: Index of spores and pollen, Jurassic-Cretaceous. Trudy VNIGRI 33, 1-137 (in russian).

Masran, Th.C. \& Pocock, S.A.J., 1981: The classification of plantderived particulate organic matter in sedimentary rocks. In: Brooks, J. (ed.): Organic maturation studies and fossil fuel exploration. Academic Press, London, 145-175.

Melia, M.B., 1984: The distribution and relationship between palynomorphs in aerosols and deep-sea sediments off the coast of Northwest Africa. Marine Geol. 58, 345-371.

Michelsen, O., 1973: On Liassic holothurian and ostracod assemblages from the Danish Embayment. D.G.U., Arbog 1972, 49-68.

Michelsen, O., 1975: Lower Jurassic biostratigraphy and ostracods of the Danish Embayment. Danm. geol. Unders. II Række 104. 287 pp. 
Michelsen, O., 1976: Preliminary report on the Jurassic litho-stratigraphic nomenclature in the Danish North Sea area. D.G.U., Årbog 1975, 105-116.

Michelsen, O., 1978: Stratigraphy and distribution of Jurassic deposits of the Norwegian-Danish Basin. D.G.U. Ser. B 2. 28 pp.

Michelsen, O., 1980: Jurassic of the Stenlille No. 1 Boring. 4 pp. D.G.U. (unpublished report).

Michelsen, O., 1989: Revision of the Jurassic lithostratigraphy of the Danish Subbasin. D.G.U. Ser. A 24. 22pp.

Michelsen, O. \& Bertelsen, F., 1979: Geotermiske reservoirformationer i den danske lagserie. D.G.U., Ärbog 1978, 151-163.

Michelsen, O., Frandsen, N., Holm, L., Jensen, T.F., Møller, J.J. \& Vejbæk, O.V., 1987: Jurassic - Lower Cretaceous of the Danish Central Trough; - depositional environments, tectonism, and reservoirs. D.G.U. Ser. A 16.45 pp.

Moore, L.R., 1968: Cannel Coals, Bogheads and Oil Shales. In: Murchison, D.C. \& Westoll, T.S. (eds.): Coal and coal bearing strata. Oliver \& Beyd, Edinburgh, 19-28.

Morbey, S.J., 1975: The palynostratigraphy of the Rhaetian stage, Upper Triassic in the Kendelbachgraben, Austria. Palaeontographica, Abt. B 152(1-3), 1-75.

Morbey, S.J., 1978: Late Triassic and Early Jurassic Subsurface palynostratigraphy in Northwestern Europe. Palinologia, núm. extraord. 1, 355-368.

Morris, K.A., 1979: A classification of Jurassic marine shale sequences: an example from the Toarcian (Lower Jurassic) of Great Britain. Palacogeogr., Palaeoclimatol., Palaeoecol., 26, 117-126.

Morris, K.A., 1980: Comparison of major sequences of organicrich mud deposition in the British Jurassic. Jl. geol. Soc. London 127, 157-170.Mudie, P.J., 1982: Pollen distribution in recent marine sediments, eastern Canada. Can. J. Earth Sci. 19(4), 729-747.

Müller, J., 1959: Palynology of Recent Orinoco delta and shelf sediments: Reports of the Orinoco Shelf Expedition; Volume 5. Micropaleontology, 5(1), 1-32.

Mädler, K., 1963: Die figurierten organischen Bestandteile der posidonienschiefer. In: Schmitz, H.H.: Zur Kenntnis des nordwestdeutschen Posidonienschiefers. Beih. Geol. Jahrb. 58, 1-119.

Mädler, K., 1964a: Bemerkenswerte Sporenformen aus dem Keuper und unteren Lias. Fortsch. Geol. Rheinld. Westf. 12, 169-200.

Mädler, K., 1964b: Die geologische Verbreitung von Sporen und pollen in der deutschen Trias. Beih. Geol. Jahrb. 65, 1-147.

NAM \& RGD (Nederlandse Aardolie Maatschappij B.V. \& Rijks Geologische Dienst), 1980: Stratigraphic Nomenclature of the Nederlands. Verh. van het Koninklijk Nederl. Geologisch Mijnbouwkundig Genootschap 32. 77 pp.

Naumova, S.N., 1934: Petrographical examinations of the coals from the Bobrikov coal mines Moscow basin. Transactions of the united geological and prospecting service of USSR 335. 46 pp. (in russian, english summary).

Naumova, S.N., 1938: Microspores from the coals of the Moscow basin. In: Petrography of coals and limestones of the Moscow basin (Symposium). Transactions of the all-union scicntific research institute of econimic mineralogy 119, 21-32 (in russian, english summary).

Nielsen, L.H. \& Koppelhus, E.B., 1991: Reworked Carboniferous palynomorphs from the Lower Jurassic of Bornholm and their palaeogeographic significance. Bull. geol. Soc. Denmark 38, 253266.

Nielsen, L.H., Larsen, F. \& Frandsen, N., 1989: Upper TriassicLower Jurassic tidal deposits of the Gassum Formation on Sjælland, Denmark. D.G.U. Ser. A 23. 30pp.

Nilsson, T., 1958: Über das Vorkommen eines mesozoischen Sapropelgesteins in Schonen. Lunds Univ. Årsskr. N.F. Avd. 2, 54(10). 112 pp.

Norris, G., 1965: Triassic and Jurassic Miospores and Acritarchs from the Beacon and Ferrar Groups, Victoria Land, Antarctica. New Zealand Jour. Geol. Geophys. 8(2), 236-277.

Norris, G., 1967: Spores and pollen from the Lower Colorado Group (Albian - ?Cenomanian) of Central Alberta. Palaeontographica, Abt. B. 120(1-4), 72-115.

Norwood, J.A., Nørvang, A. \& von Elm, C., 1951: Final Report on Gassum No. 1. 134 pp. D.G.U. (unpublished report).

Nørvang, A., 1957: The Foraminifera of the Lias series in Jutland, Denmark. Meddr. dansk geol. Foren. 13(5), 1-413.

Orbell, G., 1973: Palynology of the British rhaeto-liassic. Bull. geol. Surv. Gr. Britain 44, 1-44.
Orlowska-Zwolinska, T., 1966: Lower Liassic age of the Wielichowo beds in the light of spore- and pollen analysis (Polish Lowland). Kwart. Geol. Inst. Warsz. 10(4), 1003-1021.

Parry, C.C., Whitley P.K.J. \& Simpson, R.D.H., 1981: Integration of palynological and sedimentological methods in facies analysis of the Brent Formation. Petrol. Geol. Continent N.W. Europe, 205215.

Patterson, W.A., Edwards, K.J. \& Maguire, D.J., 1987: Microscopic charcoal as a fossil indicator of fire. Quatenary Sci. Rev. 6, 3-23.

Pautsch, M.E., 1958: Keuper sporomorphs from Swierczyna, Poland. Micropaleontology 4(3), 321-325.

Pedersen, G.K., 1983: En sedimentologisk undersøgelse af den Nedre Jurassiske Fjerritslev Formation i Det danske Subbassin. 43 pp. University of Copenhagen (unpublished thesis).

Pedersen, G.K., 1985: Thin, fine-grained storm layers in a muddy shelf sequence: an example from the Lower Jurassic in the Stenlille I well, Denmark. Jl. geol. Soc. London, 357-374.

Pedersen, G.K., 1986: Changes in the bivalve assemblage of an early Jurassic mudstone sequence (The Fjerritslev Formation in the Gassum No. 1-well). Palaeogeogr. Palaeoclimatol. Palaeoecol. 53, 139-168.

Pedersen, K.R. \& Lund, J.J., 1980: Palynology of the plantbearing Rhaetian to Hettangian Kap Stewart Formation, Scoresby Sund, East Greenland. Rev. Palaeobot. Palynol. 31, 1-69.

Pflug, H.D., 1953: Zur Entstehung und Entwicklung des angiospermiden Pollens in der Erdgeschichte. Palaeontographica, Abt. B 95(4-6), 60-171.

Piasecki, S., 1986: Palynological analysis of the organic debris in the Lower Cretaceous Jydegård Formation, Bornholm, Denmark. Grana 25, 119-129.

Piel, K.M. \& Evitt, W.R., 1980: Paratabulation in the Jurassic dinoflagellate genus Nannoceratopsis and a comparison with modern taxa. Palynology 4, 79-104.

Playford, G., 1962: Lower Carboniferous microfloras of Spitsbergen. Palacontology 5(3), 550-618.

Playford, G. \& Dettmann, M.E., 1965: Rhaeto-Liassic plant microfossils from the Leigh Creek Coal Measures, South Australia. Senck. leth. 46(2/3), 127-181.

Pocock, S.A.J., 1961: Microspores from the Genus Murospora Somers from Mesozoic strata of Western Canada and Australia. J. Paleont. 35(6), 1131-1134.

Pocock, S.A.J., 1962: Mikrofloral analysis and age determination of strata at the Jurassic-Cretaceous boundary in the Western Canada Plains. Palaeontographica, Abt. B 111(1-3), 1-95.

Pocock, S.A.J., 1970: Palynology of the Jurassic sediments of Western Canada. Part I. Terrestrial species. Palaeontographica, Abt. B 130(1-2), 12-72.

Pocock, S.A.J., 1982: Identification and recording of particulate sedimentary orgainc matter. In: Staplin, F.L. et al. (eds.): How to Assess Maturation and Paleotemperatures. Short Course 7, Soc. Econ. Pal. Min., 13-130.

Pocock, S.A.J. \& Jansonius, J., 1961: The pollen genus Classopollis Pflug 1953. Micropalaeontology 7(4), 439-449.

Potonié, R., 1956: Synopsis der Gattungen der Sporae dispersae. 1. Teil: Sporites. Beih. Geol. Jahrb. 23. 103 pp.

Potonié, R. \& Kremp, G., 1954: Die Gattungen der paläozoischen Sporae dispersae und ihre Stratigraphie. Geol. Jb. 69, Hannover, 111-194.

Potonié, R. \& Venitz, H., 1934: Zur Mikrobotanik des miozänen Humodils der niederrheinischen Bucht. Arb. Inst. Paläobot. Petrogr. Brennsteine, 5, 5-54.

Reaugh, A.B., 1978: A new excystment mechanism in the Silurian acritarch Diexallophasis of Virginia. Palaeontology 21(4), 869-872.

Reid, P.C., 1972: The distribution of dinoflagellate cysts, acritarchs and pollen in coastal sediments from the British Isles. $277 \mathrm{pp}$. Sheffield (unpublished Ph.D. thesis).

Reinhardt, P., 1962: Sporae dispersae aus den Rhät Thüringens. Mbr. deutsch. Akad. Wiss. Berlin 3(11/12), 704-711.

Reinhardt, P., 1964: Über die Sporae dispersae der Thüringer Trias. Mbr. deutsch. Akad. Wiss. Berlin 6(1), 46-56.

Reissinger, A., 1950: Die "Pollenanalyse" ausgedehnt auf alle Sedimentgesteine der geologischen Vergangenheit. II Teil. Palaeontographica, Abt. B 90(4-6), 99-126.

Rhys, G.H., 1974: A proposed standard lithostratigraphic nomenclature from the Southern North Sea. Inst. Geol. Sci. Rep. No. 74/8. 14 pp. 
Riding, J.B., 1983: The palynology of the Aalenian (Middle Jurassic) sediments of the Jackdaw Quarry, Stanway Hill, Gloucestershire, England. Mercian Geologist 9, 111-120.

Riding, J.B., 1984: A palynological investigation of Toarcian to early Aalenian strata from the Blea Wyke area, Ravenscar, North Yorkshire. Proc. Yorkshire Geol. Soc. 45, 109-122.

Riegel, W., Loh, H., Maul, B. \& Prauss, M., 1986: Effects and causes in a black shale event - The Toarcian Posidonia Shale of NW Germany. In: Walliser, O. (ed.): Lecture Notes in Earth Sciences, vol. 8. Global Bio-Events. Springer-Verlag, Berlin, Heidelberg, 267-276.

Rogalska, M., 1954: Spore and pollen analysis of the Liassic coal of Blanowice in Upper Silesia. Inst. Geol. Warschau Bull. 89, 1-46.

Rolle, F., Koch, J.O., Frandsen, N. \& Surlyk, F., 1979: Jurassic environments in the Fenno-Scandian Border Zone. Symposium "Sedimentation jurassic W-européen". A.S.F. Publication spéciale No. 1, 15-31.

Ross, N.E., 1949: Investigations of the Senonian of the Kristianstad District, S. Sweden. I: On a Cretaceous Pollen and Spore Bearing Clay Deposit of Scania. Bull. geol. Inst. Univ. Uppsala 34, 25-46.

Sarjeant, W.A.S., 1963: Fossil dinoflagellates from Upper Triassic sediments. Nature, London 199, 353-354.

Sarjeant, W.A.S., 1968: Microplankton from the Upper Callovian and Lower Oxfordian of Normandy. Rev. Micropaléontol. 10, 221-242.

Scheuring, B.W., 1978: Mikrofloren aus den Meridekalken des Mte. San Giorgio (Kanton Tessin). Schweiz. Paläont. Abh. 100. 205 pp.

Schmidt, B.J., 1985a: Clay mineral investigation of the RhaeticJurassic-Lower Cretaceous sediments of the Børglum 1 and Uglev 1 wells, Denmark. Bull. geol. Soc. Denmark 34, 97-110.

Schmidt, B.J., 1985b: A coal petrographic source rock evaluation of the Rhaetic-Jurassic-Lower Cretaceous sediments of the Børglum 1 and Uglev 1 wells, Denmark. Bull. geol. Soc. Denmark 33, 239-252.

Schopf, J.M., 1948: Variable coalification: The process involved in coal formation. Econ. Geology 43(3), 207- 225.

Schopf, J.M., 1975: Modes of fossil preservation. Rev. Palaeobot. Palynol. 20, 27-53.

Schopf, J.M., Wilson L.R. \& Bentall, R., 1944: An Annotated Synopsis of Paleozoic Spores and the Definition of Generic Groups. Illinois Geol. Surv., Rept. Inv. 91. 73 pp. In: Catalog of Fossil Spores and Pollen 5 (1959), 1-4.

Schulz, E., 1962: Sporenpaläontologische Untersuchungen zur Rhät Lias-Grenze in Thüringen und der Altmark. Geologie, Berlin 11 (3), 308-320.

Schulz, E., 1966: Über einige neue Sporae dispersae aus dem älteren Mesophytikum Deutschlands. Geologie, Berlin 15(55), 130-151.

Schulz, E., 1967: Sporenpaläontologische Untersuchungen rätoliassischer Schichten im Zentralteil des Germanischen Beckens. Paläont. Abh. B 2(3), 427-633.

Schulz, E., 1970: Die Sporen der Gattung Stereisporites Thomson \& Pflug 1953 aus dem älteren Mesophytikum des Germanischen Beckens. Paläont. Abh. B 3(3-4), 683-719.

Schulz, E. \& Mai, D.H., 1966: Erläuterungen zur tabelle der stratigraphischen verbreitung der sporen und pollen im Lias und Dogger. In: Döring, H., Krutzsch, W., Mai, D.H. \& Schulz, E., 1966: Erläuterungen zu den sporenstratigraphischen Tabellen vom Zechstein bis zum Oligozän. Abh. zentr. geol. Inst. 8, 21-34.

Scott, R.W., 1982: Palynomorphs are neglected elements in paleocommunities. In: Mamet, B. \& Copeland, M.J. (eds.): Third North American Paleontological Convention. Proc., 471-476.

Scull, B.J., Felix, C.J., McCaleb, S.B. \& Shaw, W.G., 1966: The interdiscipline approach to paleoenvironmental interpretations. Transact. - Gulf Coast Ass. Geol. Soc. 16, 81-117.

Seilacher, A., 1982: Ammonite shells as habitats in the Posidonia Shales of Holzmaden - floats or benthic islands. N. Jb. Geol. Paläont. H.2, 98-114.

Singh, H.P., 1971: Palynology of the Lower Cretaceous sediments of India. Seminar on paleopalynology and Indian stratigraphy, 159166 .

Smelror, M., 1987: Early Silurian acritarchs and prasinophycean algae from the Ringerike District, Oslo Region (Norway). Rev. Palaeobot. Palynol. 52, 137-159.

Smith, A.H.V. \& Butterworth, M.A., 1967: Miospores in the coal seams of the Carboniferous of Great Britain. Spec. Papers Palaeont. 1. 324 pp. Palaeont. Assoc., London
Smith, D.M., Griffin, J.J. \& Goldberg, E.D., 1973: Elemental carbon in marine sediments: A baseline for burning. Nature 241, 268-270.

Somers, G., 1952: A preliminary study of the fossil spore content of the lower Jubilee seam of the Sydney coalfield, Nova Scotia. Publ. Nova Scotia Found., Halifax, 1-30

Sommer, F.W., 1956: South American Paleozoic sporomorphae without haptotypic structures. Micropaleontology 2, 175-181.

Sorgenfrei, T. \& Buch, A., 1964: Deep Tests in Denmark 1935-1959. Danm. geol. Unders. III Rakke $36.146 \mathrm{pp}$

Srivastava, S.K., 1976: The fossil pollen genus Classopollis. Lethaia $9,437-457$

Srivastava, S.K., 1987: Jurassic spore-pollen assemblages from Normandy (France) and Germany. Geobios 20(1), 5-79.

Stanley, E.A., 1965: Abundance of pollen and spores in marine sediments off the eastern coast of the United States. SEast Geol. $7(1), 25-33$.

Stanley, E.A., 1969: Marine palynology. Oceanogr. Mar. Biol. Ann. Rev. 7, 227-292

Staplin, F.L., 1961: Reef-controlled distribution of Devonian microplankton in Alberta. Palaeontology 4(3), 392-424.

Staplin, F.L., 1969: Sedimentary organic matter, organic metamorphism, and oil and gas occurrence. Bull. Can. Petr. Geol. 17(1), 47-66.

Staplin, F.L., 1977: Interpretation of thermal history from color of particulate organic matter - a review. Palynology 1, 9-18.

Stockmans, F. \& Williére, Y., 1963: Les Hystrichospheres ou mieux les acritarches du Silurien belge. Sondage de la Brassierie Lust a Courtrai (Kortrijk). Bull. Soc. belge Géol. Paléont. Hydrol. 71, $450-481$.

Summerhayes, C.P., 1981: Organic facies of Middle Cretaceous black Shales in deep North Atlantic. Bull. Am. Assoc. Petrol. Geol. 65(11), 2364-2380.

Summerhayes, C.P., 1987: Organic-rich Cretaceous sediments from the North Atlantic. In: Brooks \& Fleet (eds.): Marine Petroleum Source Rocks. Spec. publ. Geol. Soc. London 26, 301-316.

Summerhayes, C.P. \& Masran, T.C., 1983: Organic facies of Cretaceous and Jurassic sediments from Deep Sea Drilling Project Site 534 in the Blake-Bahama Basin, western North Atlantic. In: Sheridan, R.E., Gradstein, F.M. et al.: Initial Report D.S.D.P. 76, $469-480$.

Surlyk, F., Clemmesen, L.B. \& Larsen, H.C., 1981: Post-Paleozoic evolution of the East Greenland continental margin. In: Kerr, J.W. \& Ferguson, A.J. (eds.): Geology of the North Atlantic Borderlands. Mem. Can. Soc. Petrol. Geol. 7, 611-645.

Tappan, H., 1980: The Paleobiology of Plant Protists. W.H. Freeman \& Co., San Francisco. 1028 pp.

Thiergart, F., 1949: Der stratigraphische Wert mesozoischer Pollen und Spores. Palaeontographica, Abt. B 89, 1-34

Thomsen, E., Lindgreen, H. \& Wrang, P., 1983: Investigation on the source rock potential of Denmark. In: Kaasschieter, J.P.H. \& Reijers, T.J.A. (eds.): Petroleum geology of the southeastern North Sea and the adjacent onshore areas (The Hague, 1982). Geol. Mijnbouw 62, 221-239.

Thomsen, E., Damtoft, K. \& Andersen, C., 1987: Hydrocarbon plays in Denmark outside the Central Trough. In: Brooks, J. \& Glennie, K. (eds.): Petroleum Geology of North West Europe. Graham \& Trotman, 375-388.

Thomson, P.W. \& Pflug, H. 1953: Pollen und Sporen des Mitteleuropäischen Tertiärs. Palaeontographica, Abt. B 94(1-4), 1-138.

Thusu, B.(ed.), 1978: Distribution of Biostratigraphically Diagnostic Dinoflagellate Cysts and Miospores from the Northwest European Continental Shelf and Adjacent Areas. IKU 100. 111 pp.

Tissot, B., Durand, B., Espitalié, J. \& Combaz, A., 1974: Influence of Nature and Diagenesis of Organic Matter in Formation of Petroleum. Am. Ass. Petr. Geol. Bull. 58(3), 499-506.

Tissot, B.P. \& Welte, D.H., 1984: Petroleum Formation and Occurrence. Second Revised and Enlarged Edition. Springer-Verlag, Berlin, Heidelberg, New York,Tokyo. 699 pp.

Tralau, H., 1968: Botanical investigations into the fossil flora of Eriksdal in Fyledalen, Scania. II. The Middle Jurassic Microflora. Sver. Geol. Unders. Ser. C. 633. 185 pp.

Traverse, A., 1955: Occurrence of the oilforming alga Botryococcus in lignites and other Tertiary sediments. Micropalaeontology 1(4), $343-350$. 
Traverse, A. \& Ginsburg, R.N., 1966: Palynology of the surface sediments of Great Bahama Bank, as related to water movement and sedimentation. Marine Geol. 4, 417-459.

Tyson, R.V., 1984: Palynofacies investigation of Callovian (Middle Jurassic) sediments from DSDP Site 534, Blake-Bahama Basin, Western Central Atlantic. Mar. Petrol. Geol. 1, 3-13.

Tyson, R.V., 1987: The genesis and palynofacies characteristics of marine petroleum source rocks. In: Brooks, J. \& Fleet, A.J. (eds.): Marine Petroleum Source Rocks. Spec. publ. Geol. Soc. London 26, 47-67.

Tyson, R.V., 1989.: Late Jurassic palynofacies trends, Piper and Kimmeridge Clay Formations, U.K. onshore and northern North Sea. In: Batten, D.J. \& Keen, M.C. (eds.): Northwest European Micropalaeontology and Palynology. The British Micropal. Soc. Series, p. 135-172.

Vail, P.R. \& Todd, R.G., 1981: Northern North Sea Jurassic unconformities, chronostratigraphy and sea-level changes from seismic stratigraphy. In: Illing, L.V. \& Hobson, G.D.(eds.), 1981: Petroleum Geology of the Continental shelf of Northwest Europe. Heyden, London, 216-235.

Vakhrameev, V.A., 1970: Range and paleoecology of Mesozoic conifers. The Cheirolepidiaceae. Paleont. Jour. 1, 12-25.

Vakhrameev, V.A., 1982: Classopollis pollen as an indicator of Jurassic and Cretaceous climate. Internat. Geol. Rev. 24(1), 11901196.

van Helden, B.G.T., 1977: Correlation of microplankton assemblages with ammonite faunas from the Jurassic Wilkic Point Formation, Prince Patrick Island, District of Franklin. Geol. Surv. Can. 77-1B, 163-171.

Van Konijnenburg-van Cittert, J.H.A., 1981: Schizaeaceous spores in situ from the Jurassic of Yorkshire, England. Rev. Palaeobot. Palynol. 33, 169-181.

Venkatachala, B.S., 1981a: Hydrocarbon Source Rock Evaluation A New Palynological Approach. Petr. Asia Jour. 4(2), 79-93.

Venkatachala, B.S., 1981b: Differentiation of amorphous organic matter types in sediments. In: Brooks, J. (ed.): Organic maturation studies and fossil fuel exploration. Academic Press, London, 177-200.

Venkatachala, B.S. \& Góczán, F., 1964: The Spore-Pollen flora of the Hungarian "Kössen Facies”. Acta Geologica 8(1-4), 203-228.

Visscher, H. \& Brugman, W.A., 1981: Ranges of selected palynomorphs in the alpine triassic of Europe. Rev. Palaeobot. Palynol. $34,115-128$.
Vollset, J., \& Doré, A.G. (eds.), 1984: A revised Triassic and Jurassic lithostratigraphic nomenclature for the Norwegian North Sea. N.P.D. Bull. 3. 53 pp.

Wall, D., 1965: Microplankton, pollen, and spores from the Lower Jurassic in Britain. Micropaleontology 11(2), 151-190.

Warren, J.S., 1973: Form and variation of the dinoflagellate Sirmiodinium grossi Alberti, from the Upper Jurassic and Lower Cretaceous of California. J. Palaeont. 47, 101-114.

Warrington, G., 1981: The indigenous micropalaeontology of British Triassic shelf sea deposits. In: Neale, J.W. \& Brasier, M.D. (eds.): Microfossils from recent and fossil shelf seas. British Micropal. Soc., 61-70.

Well Data Summary Sheets, 1981: Volume 2. D.G.U. 186 pp.

Wetzel, O., 1933: Die in organischer substanz erhaltenen Mikrofossilien des baltischen Kreide-Feuersteins mit einem sediment-petrographischen und stratigraphischen Anhang. Palaeontographica, Abt. A 78, 1-110.

Wicander, R. \& Playford, G., 1985: Acritarchs and spores from the Upper Devonian Lime Creek Formation, Iowa, U.S.A. Micropalaeontology 31(2), 97-138.

Wille, W., 1982: Evolution and ecology of Upper Liassic dinoflagellates from SW Germany. N. Jb. Geol. Paläont. Abh. 164 (1-2), 74-82.

Wille, W. \& Gocht, H., 1979: Dinoflagellaten aus dem Lias Südwestdeutschlands. N. Jb. Geol. Paläont. Abh. 158(2), 221-258.

Williams, G.L., 1977: Dinocysts: Their classification, biostratigraphy and palaeoecology. In: Ramsay, A.T.S. (ed.): Oceanic Micropalaeontology. Academic Press, London, New York, San Francisco 2, 1231-1326.

Wilson, L.R. \& Webster, R.M., 1946: Plant microfossils from a Fort Union coal of Montana. Am. Jour. Bot. 33(4), 271-278.

Woollam, R. \& Riding, J.B., 1983: Dinoflagellate cyst zonation of the English Jurassic. Inst. Geol. Sci. Rep. 83(2). 42 pp.

Yingst, J.Y. \& Rhoads, D.C., 1980: The role of bioturbation in the enhancement of bacterial growth rates in marine sediments. In: Tenore, K.R. \& Coull, B.C. (eds.): Marine Benthic Dynamics. Univ. S. Carolina Press, 407-421.

Ziegler, P.A., 1982: Geological Atlas of Western and Central Europe. Shell Internat. Pet. Maatschappij, b.v. 130 pp. 
On plates 1-20 are shown specimens recorded in the present study. The number of the sample, from which the illustrated specimen was recorded, is given in the figure text. The slides containing the illustrated specimens are deposited at the Geological Survey of Denmark, together with a list of stage coordinates from the microscope. Plates 21 and 22 show new photos of the holotypes of some of the species erected by Nilsson (1958).

All magnifications are $\mathrm{x} 1000$, unless otherwise stated. 


\section{PLATE 1}

Fig. 1. Deltoidospora toralis (Leschik 1955) Lund 1977. Sample St-5,c.

Fig. 2. Deltoidospora minor (Couper 1958) Pocock 1970. Sample Frh-13,s.

Fig. 3. Deltoidospora cf. minor (Couper 1958) Pocock 1970. Sample Frh-19,c.

Fig. 4. Cibotiumspora jurienensis (Balme 1957) Filatoff 1975. Sample Fj-9,c.

Fig. 5. Tripartina variabilis Malyavkina 1949. Sample Frh-17,c.

Fig. 6. Intrapunctisporis toralis (Leschik 1955) Lund 1977. Proximal side (high focus). Sample Frh-17,c.

Fig. 7. Same specimen as fig. 6. Proximal side (lower focus).

Fig. 8. Punctatisporites globosus (Leschik 1955) Lund 1977. Sample Frh-12,c.

Fig. 9. Retusotriletes cf. mesozoicus Klaus 1960. NOTICE: Magnification x500. Sample St-11,c.

Fig. 10. Calamospora tener (Leschik 1955) Mädler 1964. Sample Frh-1,c.

Fig. 11. Stereisporites stereoides (Potonié \& Vernitz 1934) Thomson \& Pflug 1953. Sample St-6,c.

Fig. 12. Stereisporites antiquasporites (Wilson \& Webster 1946) Dettmann 1963. Sample St-6,c.

Fig. 13. Stereisporites punctus (Klaus 1960) Krutzsch 1963. Proximal side (high focus). Sample Frh-9,c.

Fig. 14. Same specimen as fig. 13. Distal side (low focus). 
Plate 1
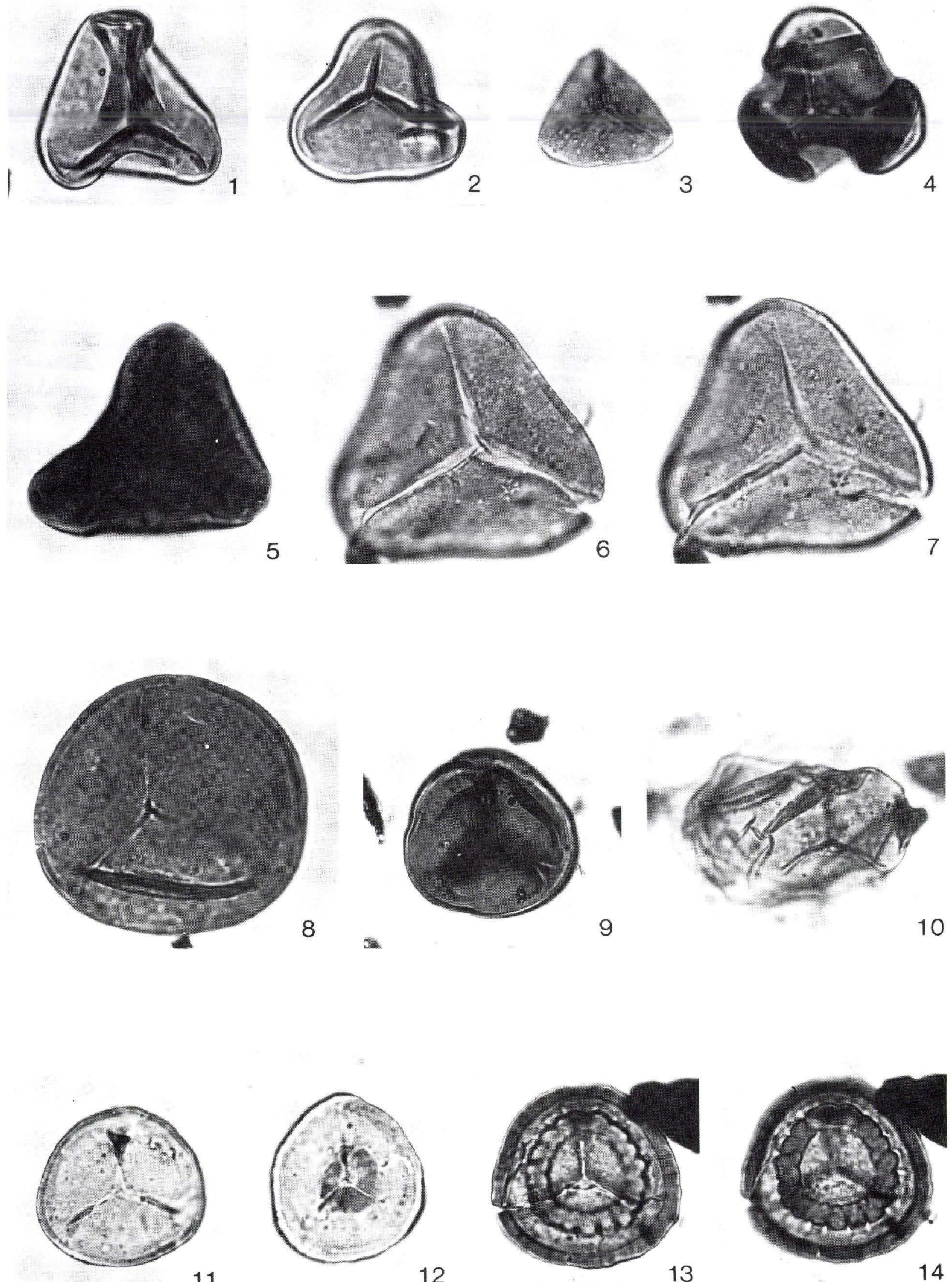

12
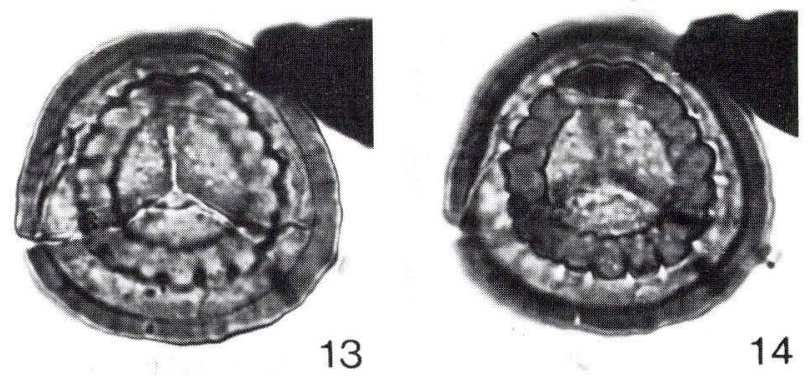
Fig. 1. Stereisporites aulosenensis (Schulz 1967) Schulz 1966. Sample Fj-16,c.

Fig. 2. Stereisporites cf. seebergensis Schulz 1966. Sample Fj-16,c.

Fig. 3. Stereisporites hauterivensis Döring 1966. Sample St-9,w.

Fig. 4. Trachysporites fuscus Nilsson 1958. Proximal side (high focus). Sample St-7,c.

Fig. 5. Same specimen as fig. 4. Distal side (low focus).

Fig. 6. Trachysporites asper Nilsson 1958. Sample Frh-12,c.

Fig. 7. Trachysporites sparsus (Bharadwaj \& Singh 1964) Lund 1977. Sample St-5,c.

Fig. 8. Trachysporites sparsus (Bharadwaj \& Singh 1964) Lund 1977. Sample St-3,c.

Fig. 9. Conbaculatisporites mesozoicus Klaus 1960. Sample St-11,c.

Fig. 10. Conbaculatisporites spinosus (Mädler 1964) Lund 1977. Sample St-14,w.

Fig. 11. Baculatisporites wellmanii (Couper 1953) Krutzsch 1959. Proximal side (high focus). Sample St-7,c.

Fig. 12. Same specimen as fig. 11. Distal side (low focus). 

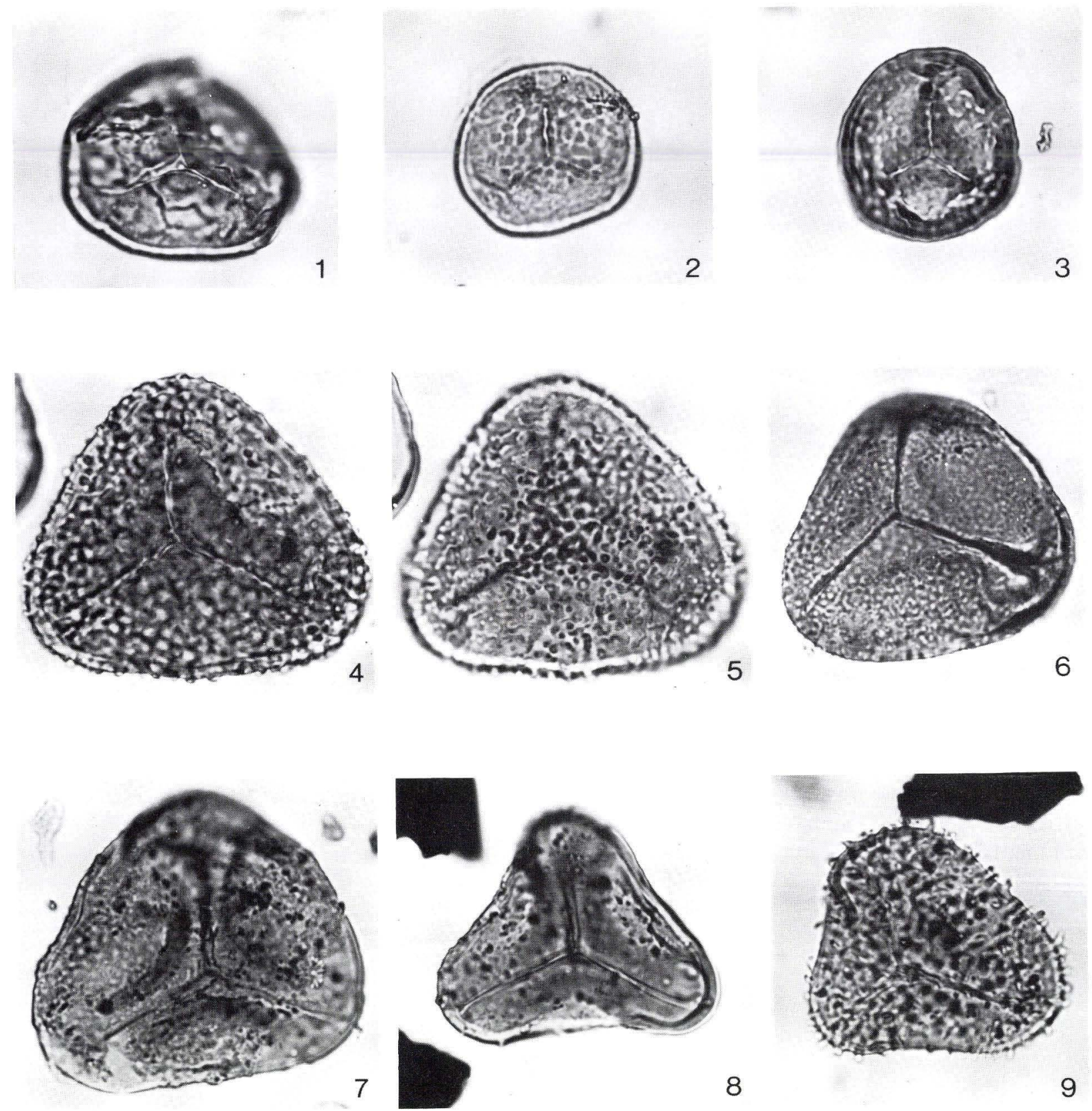

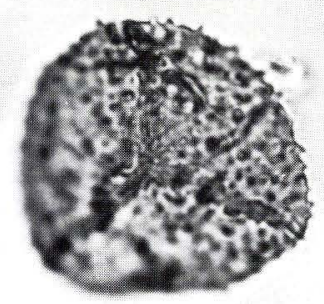

10

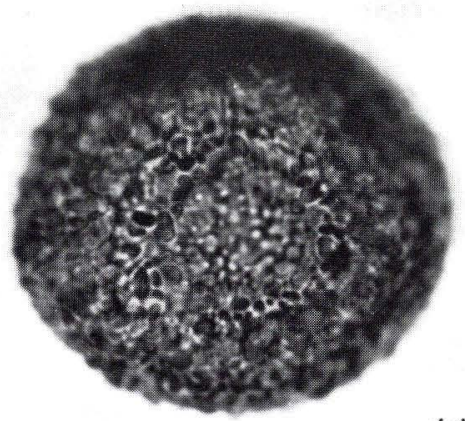

11

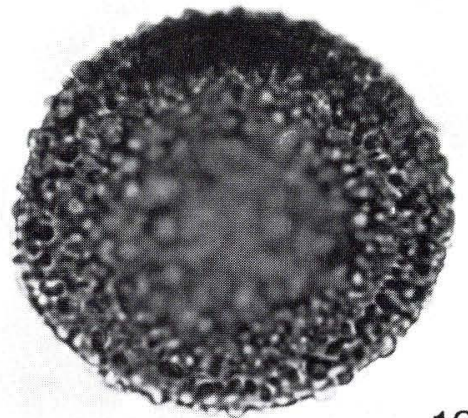

12 


\section{PLATE 3}

Fig. 1. Apiculatisporites ovalis (Nilsson 1958) Norris 1964. Proximal side (high focus). Sample St-7,c.

Fig. 2. Same specimen as fig. 1. Proximal side (lower focus).

Fig. 3. Baculatisporites oppressus (Leschik 1955) Lund 1977. Sample St-11,w.

Fig. 4. Apiculatisporites ovalis (Nilsson 1958) Norris 1964. Proximal side (high focus). Sample Frh-9,c.

Fig. 5. Same specimen as fig. 4. Distal side (low focus).

Fig. 6. Baculatisporites comaumensis (Cookson 1953) Potonié 1956. Sample Frh-18,c.

Fig. 7. Conbaculatisporites sp. 1. Sample Frh-16,c.

Fig. 8. Anapiculatisporites telephorus (Pautsch 1958) Klaus 1960. Distal side (high focus). Sample St-8,w

Fig. 9. Same specimen as fig. 8. Distal side (lower focus).

Fig. 10. Taurocusporites verrucatus Schulz 1967. Proximal side (high focus). Sample St-17,w.

Fig. 11. Same specimen as fig. 10. Proximal side (lower focus).

Fig. 12. Foraminisporis jurassicus Schulz 1967. Sample Frh-17,c. 
Plate 3
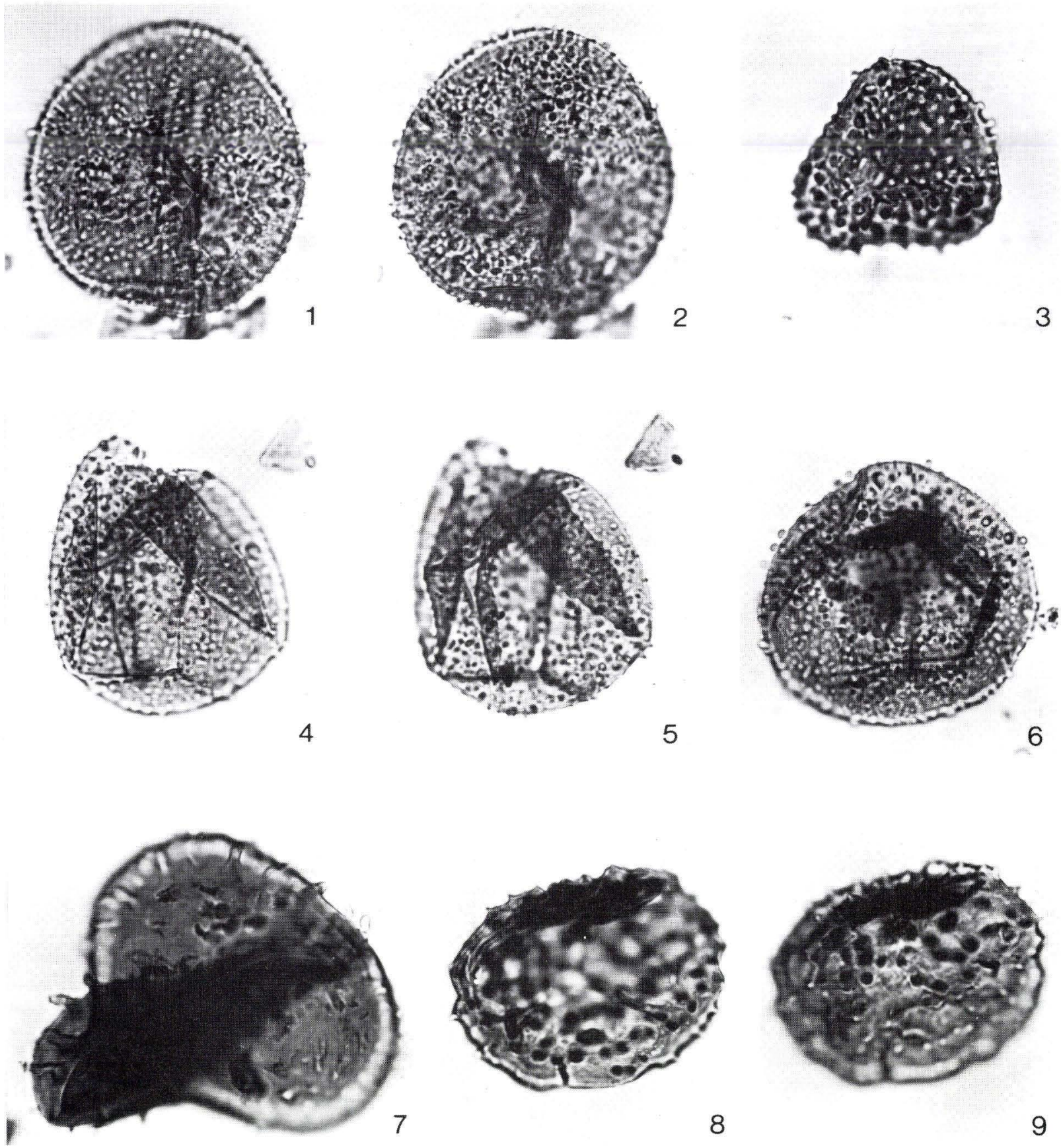

8

9

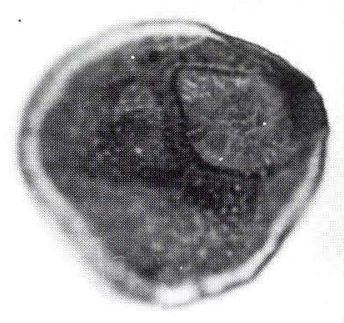

10

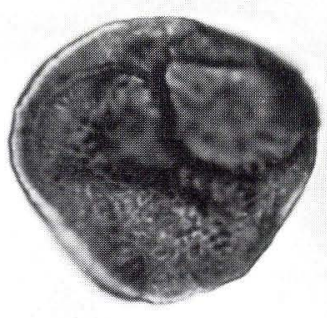

11

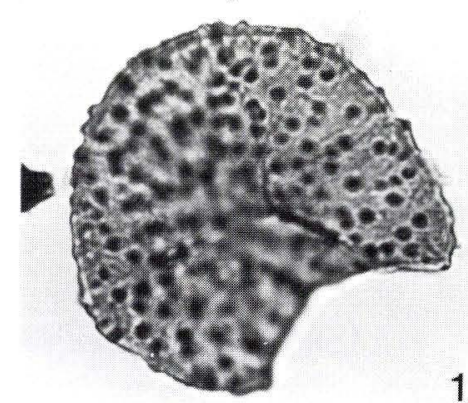


Fig. 1. Uvaesporites argenteaeformis (Bolchovitina 1953) Schulz 1967. Proximal side (low focus). Sample Frh-23,s.

Fig. 2. Same specimen as fig. 1. Distal side (higher focus).

Fig. 3. Same specimen as fig. 1. Distal side (high focus).

Fig. 4. Uvaesporites argenteaeformis (Bolchovitina 1953) Schulz 1967. Proximal side (high focus). Sample Frh-24,s.

Fig. 5. Manumia delcourtii (Pocock 1970) comb. nov. et emend. Sample Fj-30,s.

Fig. 6. Cf. Manumia sp. 1. Sample Fj-32,s.

Fig. 7. Same specimen as fig. 4. Distal side (low focus).

Fig. 8. Polypodiisporites polymicroforatus (Orlowska-Zwolinska 1966) Lund 1977. Sample Fj-3,c.

Fig. 9. Polypodiisporites polymicroforatus (Orlowska-Zwolinska (1966) Lund 1977. Sample Fj-2,c.

Fig. 10. Polypodiisporites ipsviciensis (de Jersey 1962) Playford \& Dettmann 1965. Sample Frh-10,c.

Fig. 11. Leptolepidites major Couper 1958. Proximal side (low focus). Sample St-16,w.

Fig. 12. Same specimen as fig. 11. Distal side (high focus). 
Plate 4
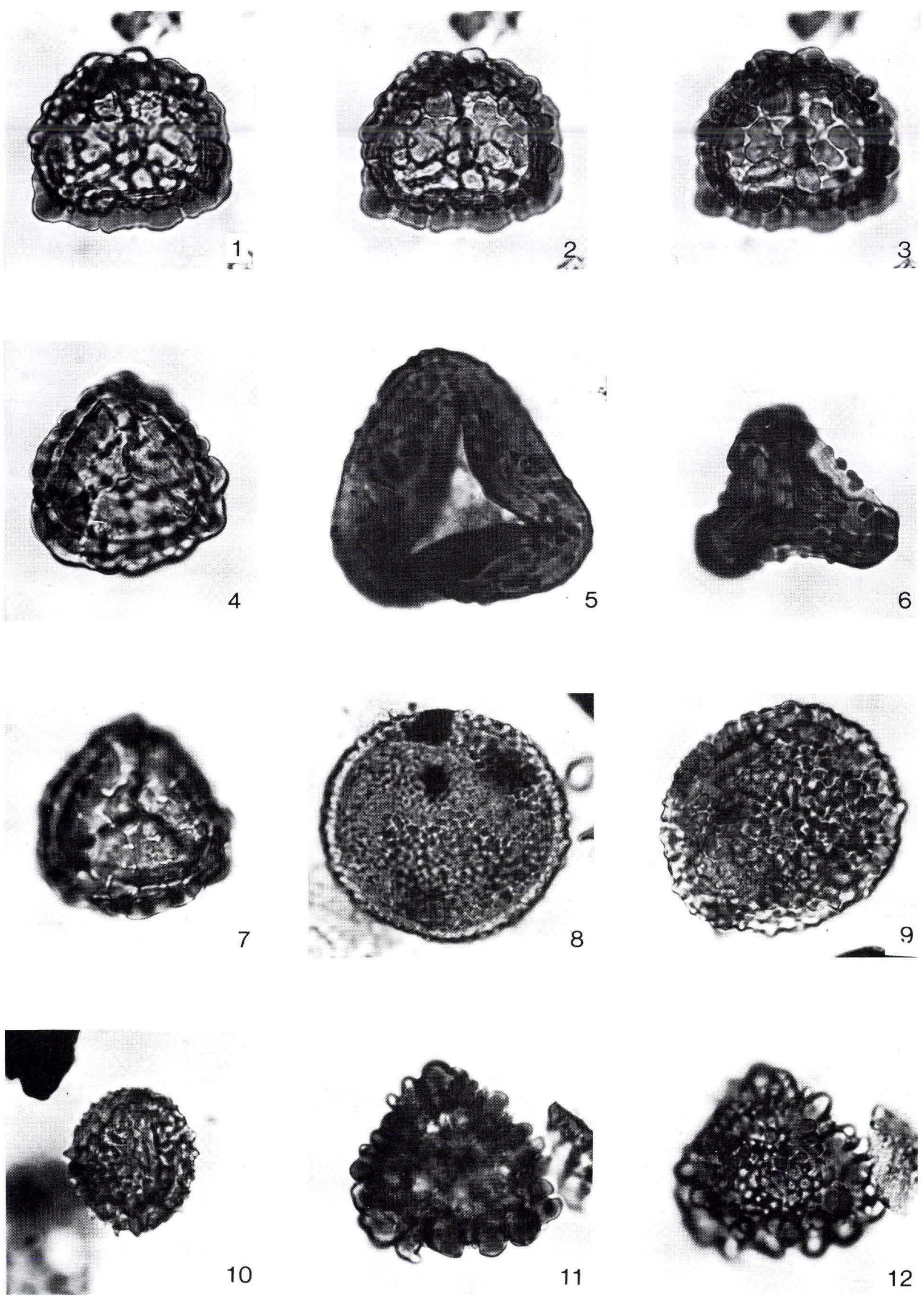

12 


\section{PLATE 5}

Fig. 1. Leptolepidites major Couper 1958. Sample Fj-14,c.

Fig. 2. Leptolepidites major Couper 1958. Sample St-16,w.

Fig. 3. Leptolepidites sp. 1. Proximal side (low focus). Sample St-16,w.

Fig. 4. Same specimen as fig. 3. Distal side (high focus).

Fig. 5. Leptolepidites sp. 2. Proximal side (low focus). Sample Frh-22,s.

Fig. 6. Same specimen as fig. 5. Distal side (high focus).

Fig. 7. Concavissimisporites variverrucatus (Couper 1958) Brenner 1963. Presumed caved. Sample Frh-20,s.

Fig. 8. Cf. Baculatisporites sp. Sample Fj-16,c.

Fig. 9. Lycopodiumsporites semimuris Danzé-Corsin \& Laveine 1963. Proximal side (high focus). Sample Fj-12,c.

Fig. 10. Same specimen as fig. 9. Distal side (low focus).

Fig. 11. Lycopodiumsporites gracilis (Nilsson 1958) Döring, Krutzsch, Mai \& Schulz 1963. Proximal side (high focus). Sample $\mathrm{Fj}-34, \mathrm{~s}$.

Fig. 12. Lycopodiumsporites austroclavatidites (Cookson 1953) Potonié 1956. Proximal side (low focus). Sample St-14,w.

Fig. 13. Same specimen as fig. 12. Distal side (high focus).

Fig. 14. Same specimen as fig. 11. Distal side (low focus). 
Plate 5
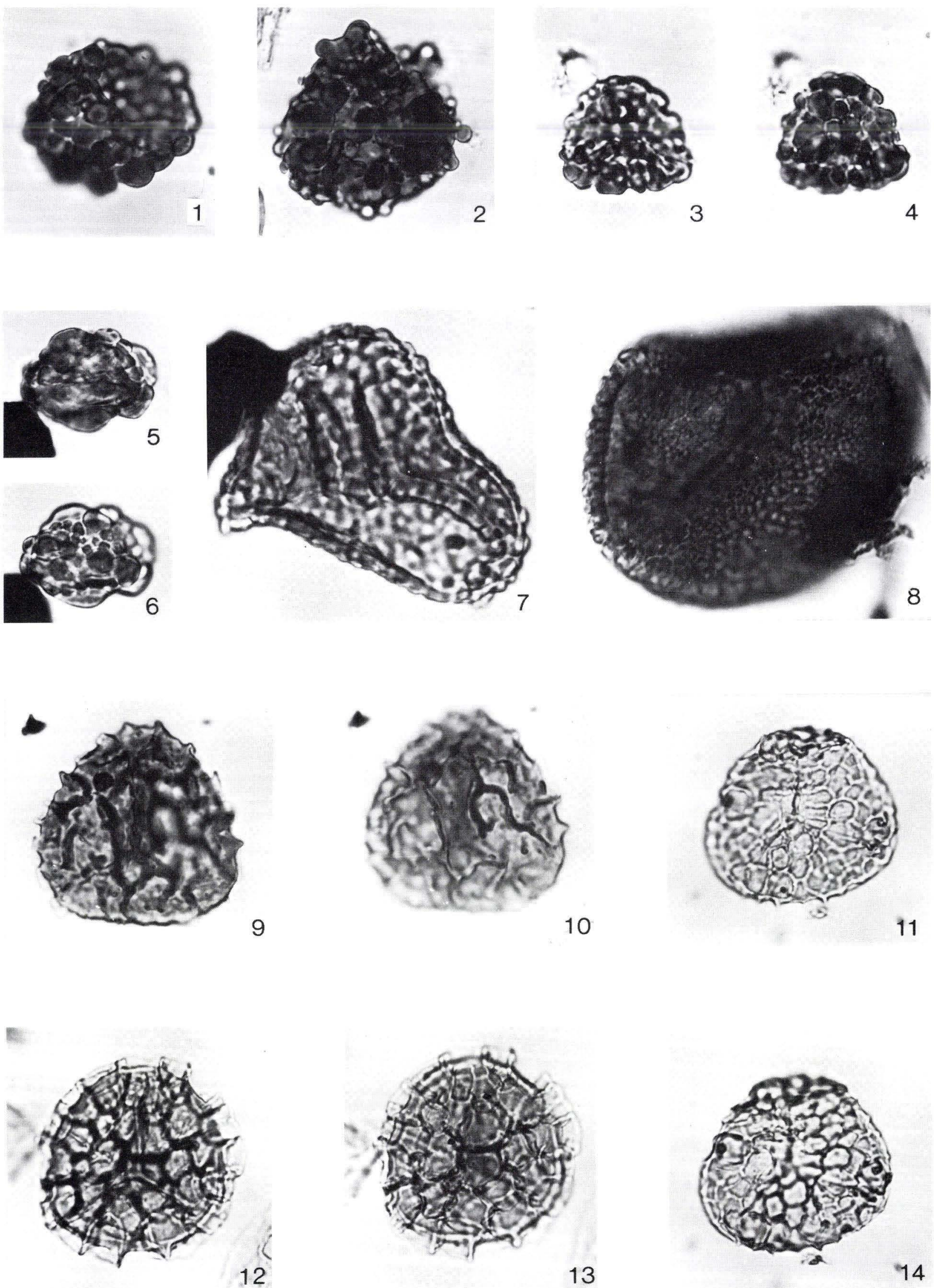

13

14 
PLATE 6

Fig. 1. Lycopodiumsporites sp.1. Proximal side (low focus). Sample Fj-16,c.

Fig. 2. Same specimen as fig. 1. Distal side (higher focus).

Fig. 3. Same specimen as figs 1 and 2. Distal side (high focus).

Fig. 4. Semiretisporis gothae Reinhardt 1962. NOTICE: Magnification x500. Sample St-3,c.

Fig. 5. Costatisulcites cf. ovatus Scheuring 3978. Sample Fj-4,c.

Fig. 6. Tigrisporites scurrandus Norris 1967. Proximal side (high focus). Sample Frh-9,c.

Fig. 7. Ischyosporites variegatus Couper 1958. Sample Frh-17,c.

Fig. 8. Same specimen as figs 6. Proximal side (lower focus). Sample Frh-17,s

Fig. 9. Cicatricosisporites hallei Delcourt \& Sprumont 1955. Presumed caved. Proximal side (high focus). Sample Frh-17,s.

Fig. 10. Same specimen as fig. 9. Distal side (low focus).

Fig. 11. Same specimen as fig. 6 and 8. Distal side (low focus). 

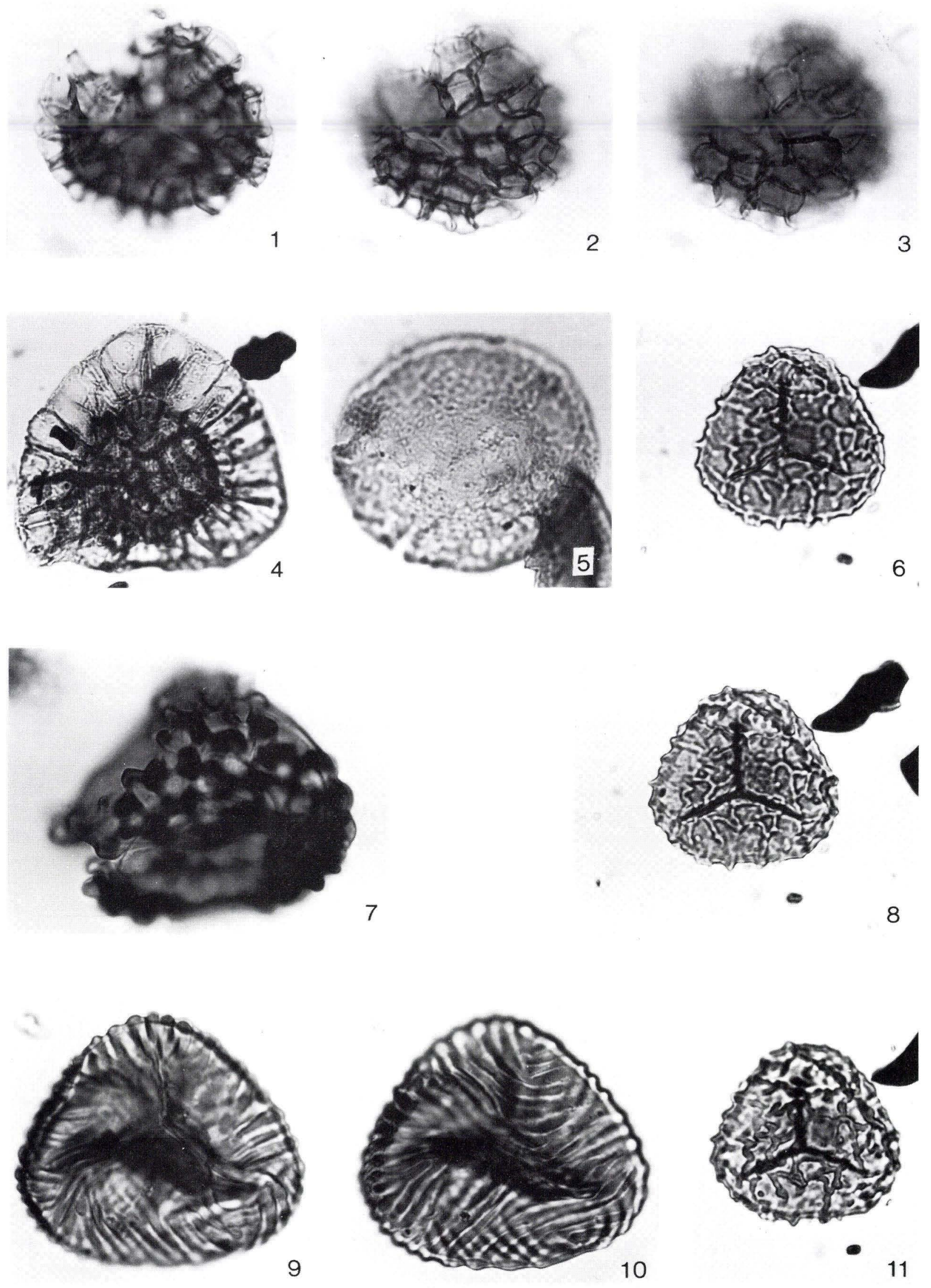
Fig. 1. Klukisporites lacunus Filatoff 1975. Sample Frh-19,c.

Fig. 2. Foveosporites labiosus Singh 1971. Presumed caved. Proximal side (high focus). Sample Fj-22,s.

Fig. 3. Same specimen as fig. 2. Distal side (low focus).

Fig. 4. Triancoraesporites ancorae (Reinhardt 1962) Schulz 1967. Sample St-3,c.

Fig. 5. Triancoraesporites ancorae (Reinhardt 1962) Schulz 1967. Sample St-3,c.

Fig. 6. Triancoraesporites reticulatus Schulz 1967. Sample St-3,c.

Fig. 7. Gleicheniidites senonicus Ross 1949. Could be caved. Proximal side (high focus). Sample Frh-23,s.

Fig. 8. Same specimen as fig. 7. Equatorial view (lower focus).

Fig. 9. Gleicheniidites cf. bulbosus Kemp 1970. Presumed caved. Sample Frh-20,s.

Fig. 10. Clavifera triplex (Bolchovitina 1953) Bolchovitina 1966. Presumed caved. Sample Frh-20,s.

Fig. 11. Zebrasporites interscriptus (Thiergart 1949) Klaus 1960. Sample St-8,c.

Fig. 12. Zebrasporites laevigatus (Schulz 1962) Schulz 1967. Sample St-3,c. 
Plate 7
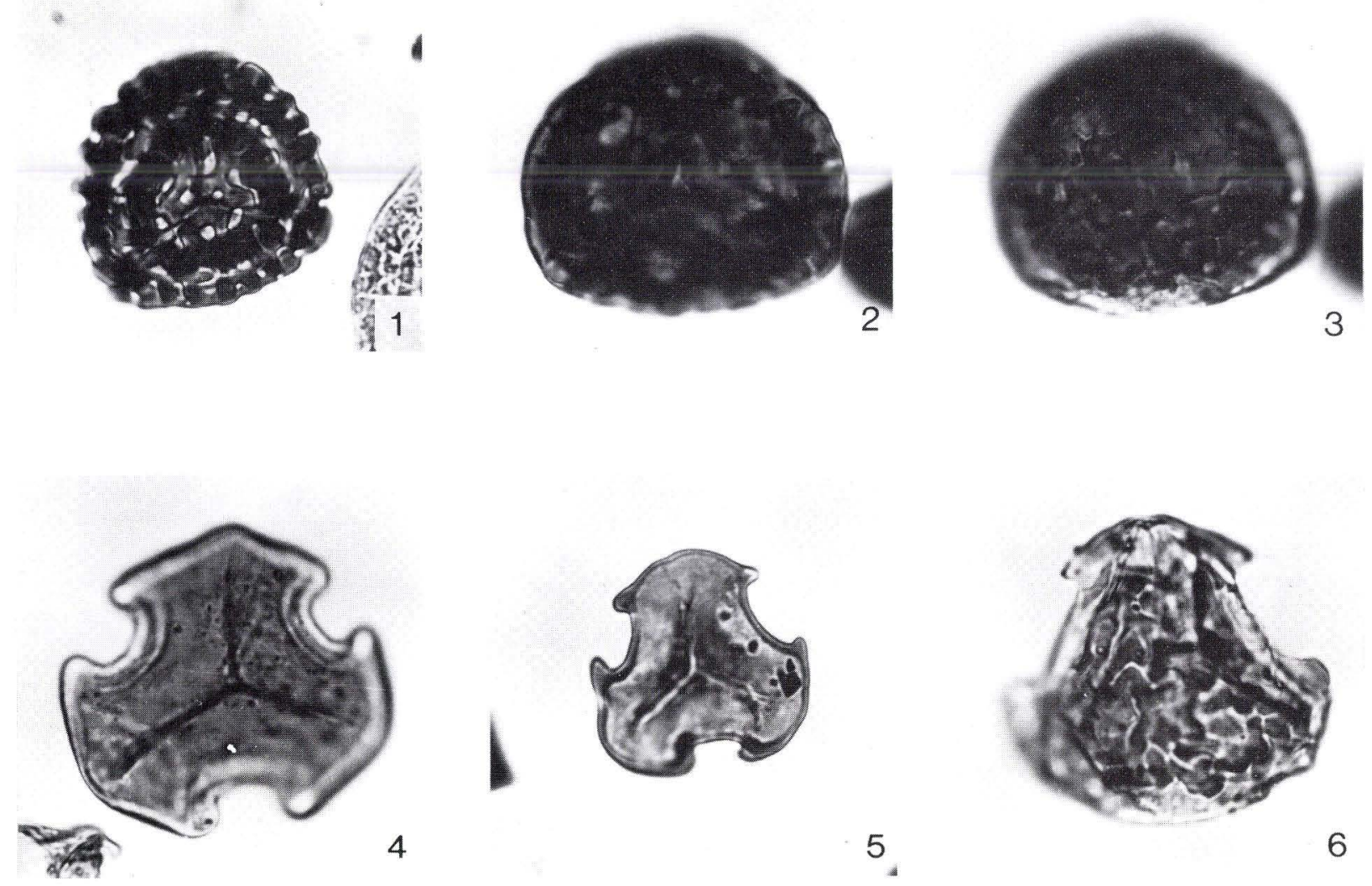

5.
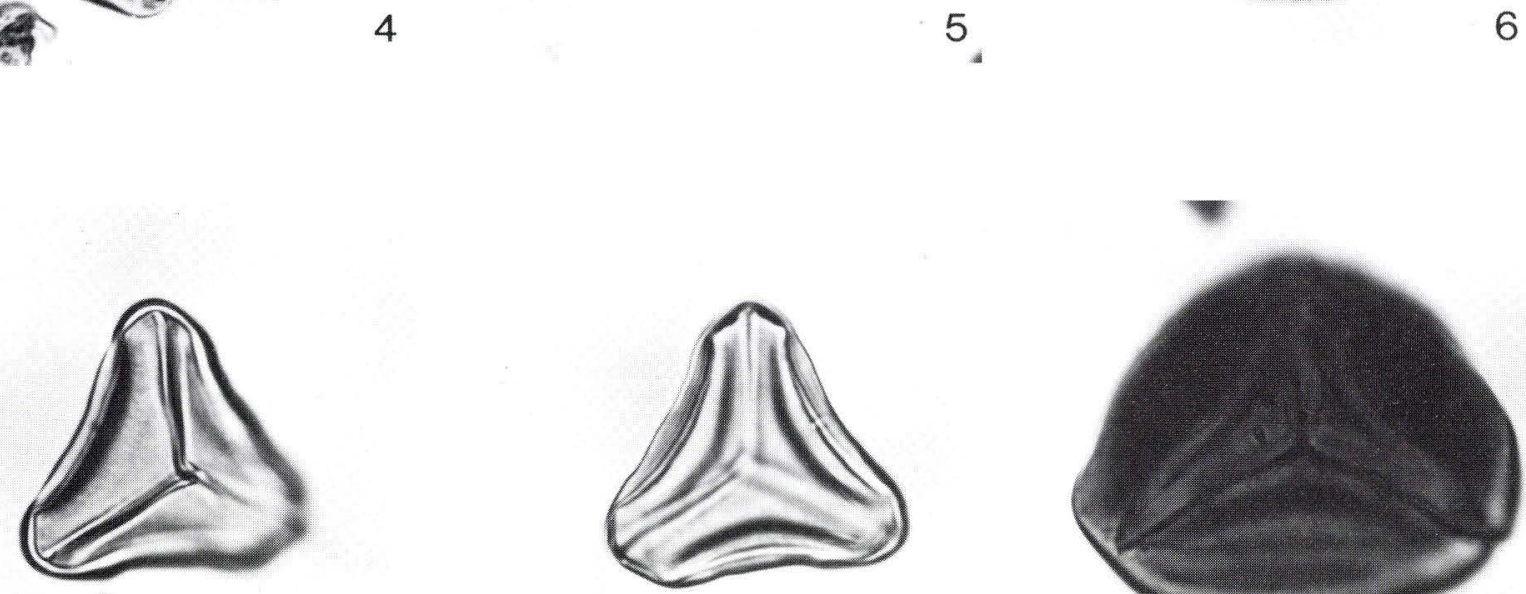

7

8
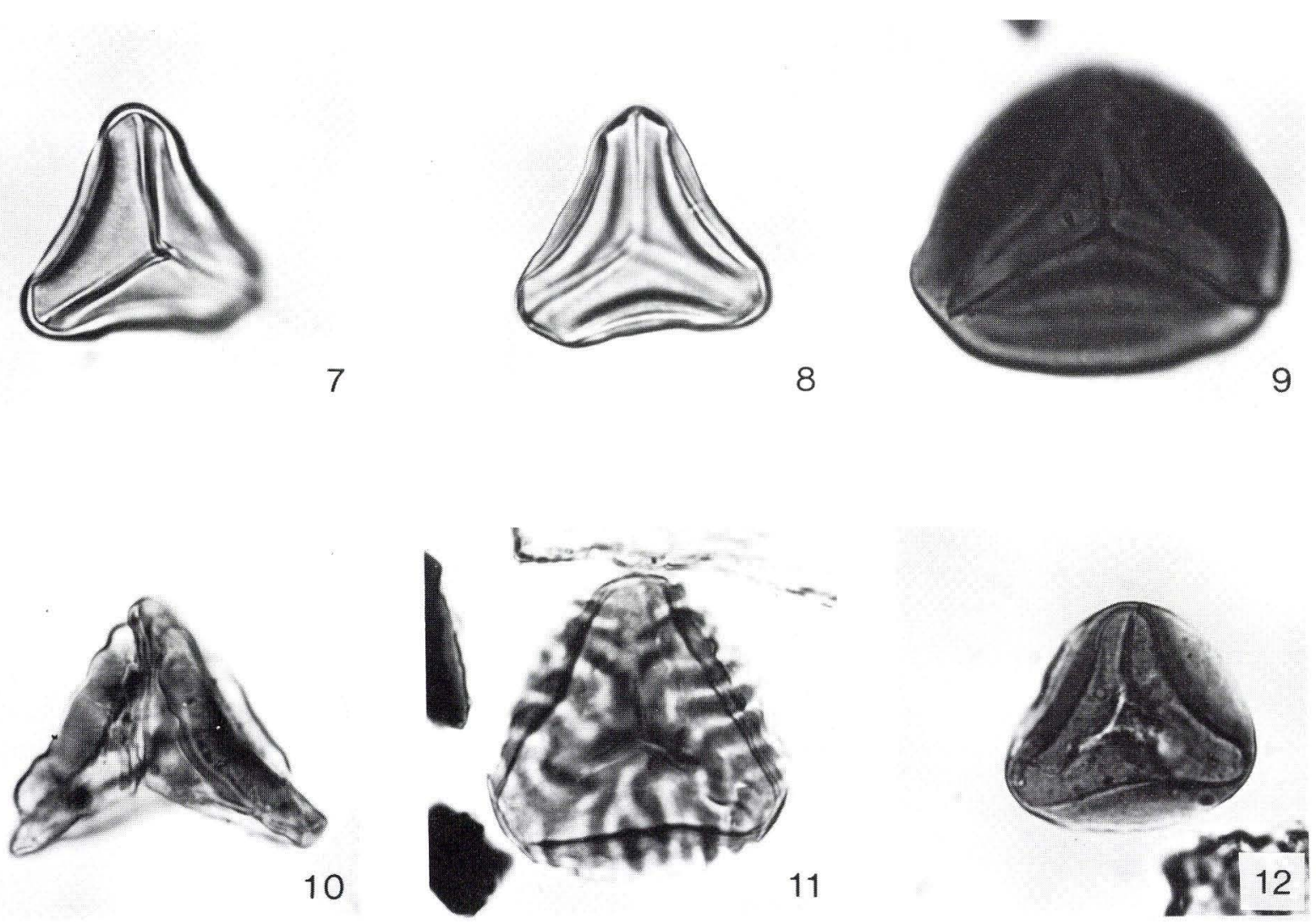


\section{PLATE 8}

Fig. 1. Camarozonosporites laevigatus Schulz 1967. Sample St-2,c.

Fig. 2. Perinosporites thuringiacus Schulz 1962. Proximal side (high focus). Sample St-3,c.

Fig. 3. Same specimen as fig. 2. Distal side (low focus).

Fig. 4. Camarozonosporites rudis Klaus 1960. Sample St-2,c.

Fig. 5. Lycospora salebrosacea (Maljavkina 1949) Schulz 1967. Could be reworked. Proximal side (high focus). Sample Fj-16,c.

Fig. 6. Same specimen as fig. 5. Distal side (low focus).

Fig. 7. Lycospora salebrosacea (Maljavkina 1949) Schulz 1967. Presumed reworked. Sample Fj-12,c.

Fig. 8. Densosporites fissus (Reinhardt 1962) Schulz 1967. Sample St-3,c.

Fig. 9. Densosporites cavernatus Orlowska-Zwolinska 1966. Proximal side (high focus). Sample St-3,c.

Fig. 10. Same specimen as fig. 9. Distal side (low focus).

Fig. 11. Cf. Densosporites ssp. Presumed reworked. Sample St-11,w.

Fig. 12. Cf. Densosporites ssp. Presumed reworked. Sample St-13,w.

Fig. 13. Cf. Densosporites ssp. Presumed reworked. Sample Fj-23,s. 
Plate 8

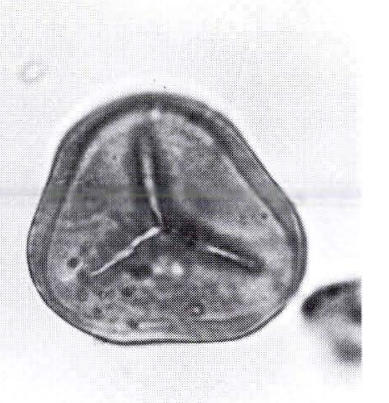

1

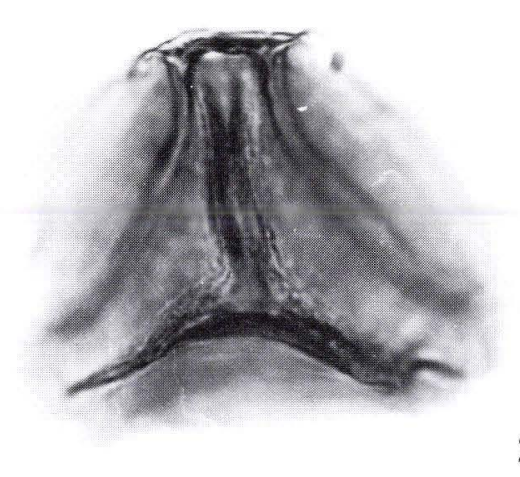

2

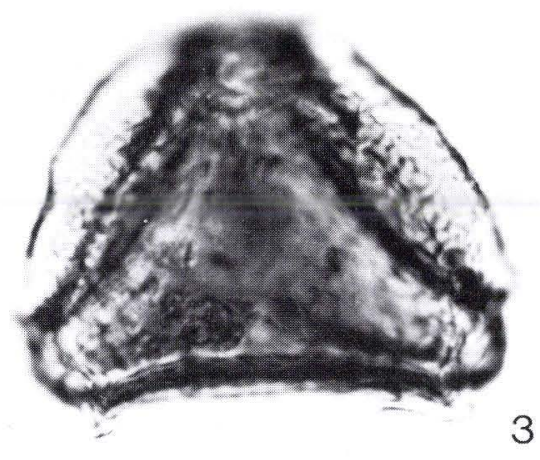

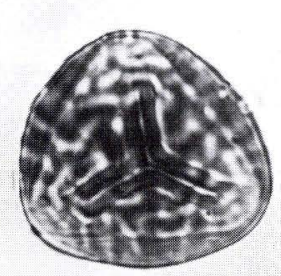

4

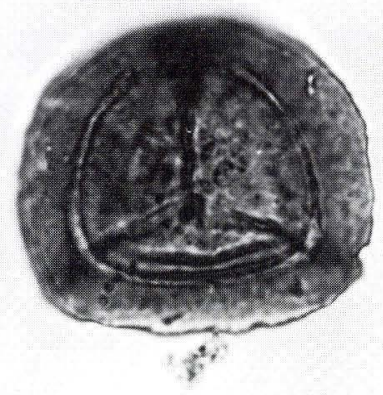

8
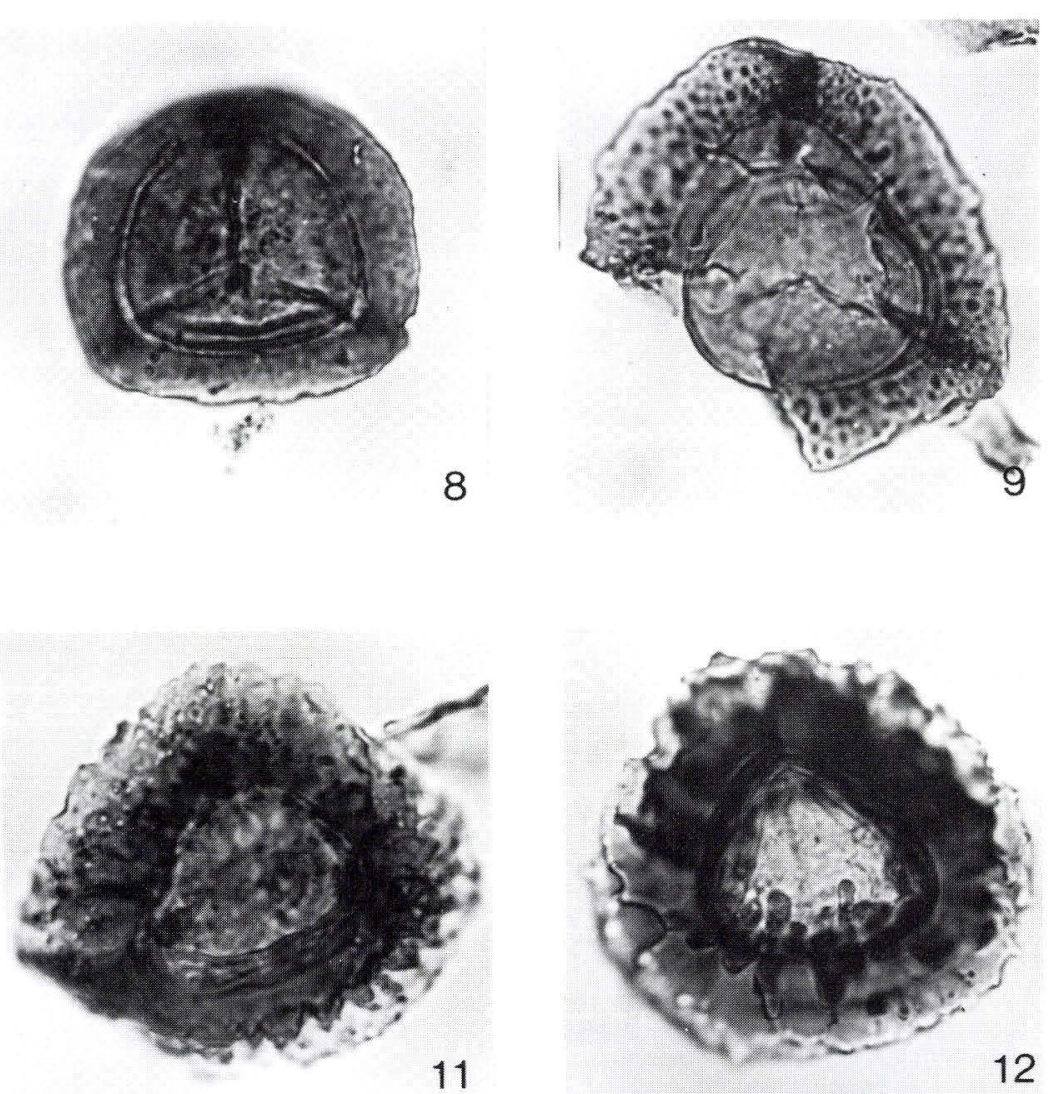

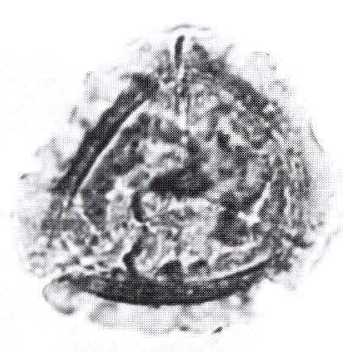

6

7

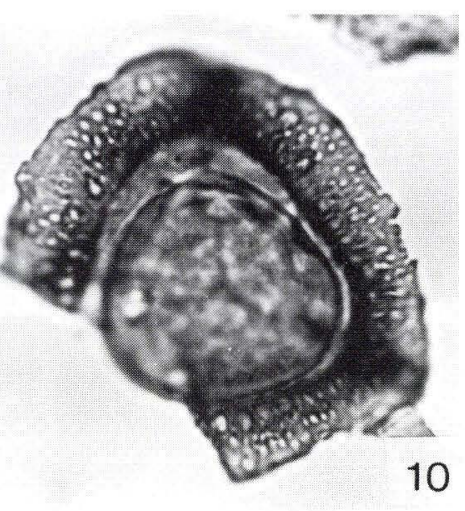




\section{PLATE 9}

Fig. 1. Cf. Crassispora sp. Presumed reworked. Sample Frh-21,c.

Fig. 2. Cingulizonates rhaeticus (Reinhardt 1961) Schulz 1967. Sample St-7,c.

Fig. 3. Cingutriletes infrapunctus (Schulz 1970) Morbey 1975. Sample Frh-2,c.

Fig. 4. Limbosporites lundbladii Nilsson 1958. Proximal side (low focus). Sample St-2,c.

Fig. 5. Same specimen as fig. 4. Distal side (high focus).

Fig. 6. Iraquispora laevigata (Mädler 1964) Lund 1977. Sample Frh-10,c.

Fig. 7. Murospora florida (Balme 1957) Pocock 1961. Sample Fj-8,s.

Fig. 8. Heliosporites altmarkensis Schulz 1962. Sample St-7,c.

Fig. 9. Cf. Murospora sp. Presumed reworked. Sample Fj-23,s. 
Plate 9
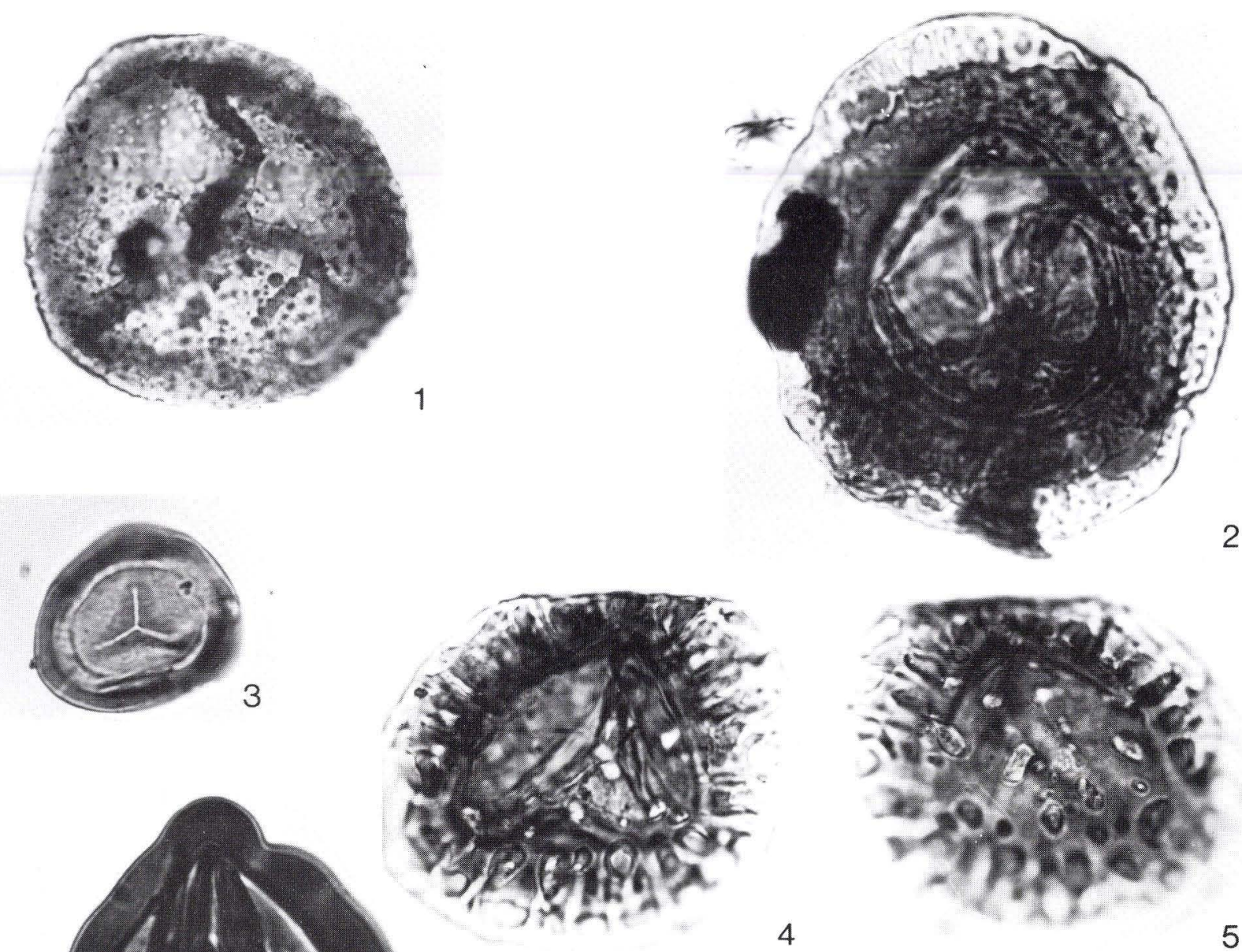

5
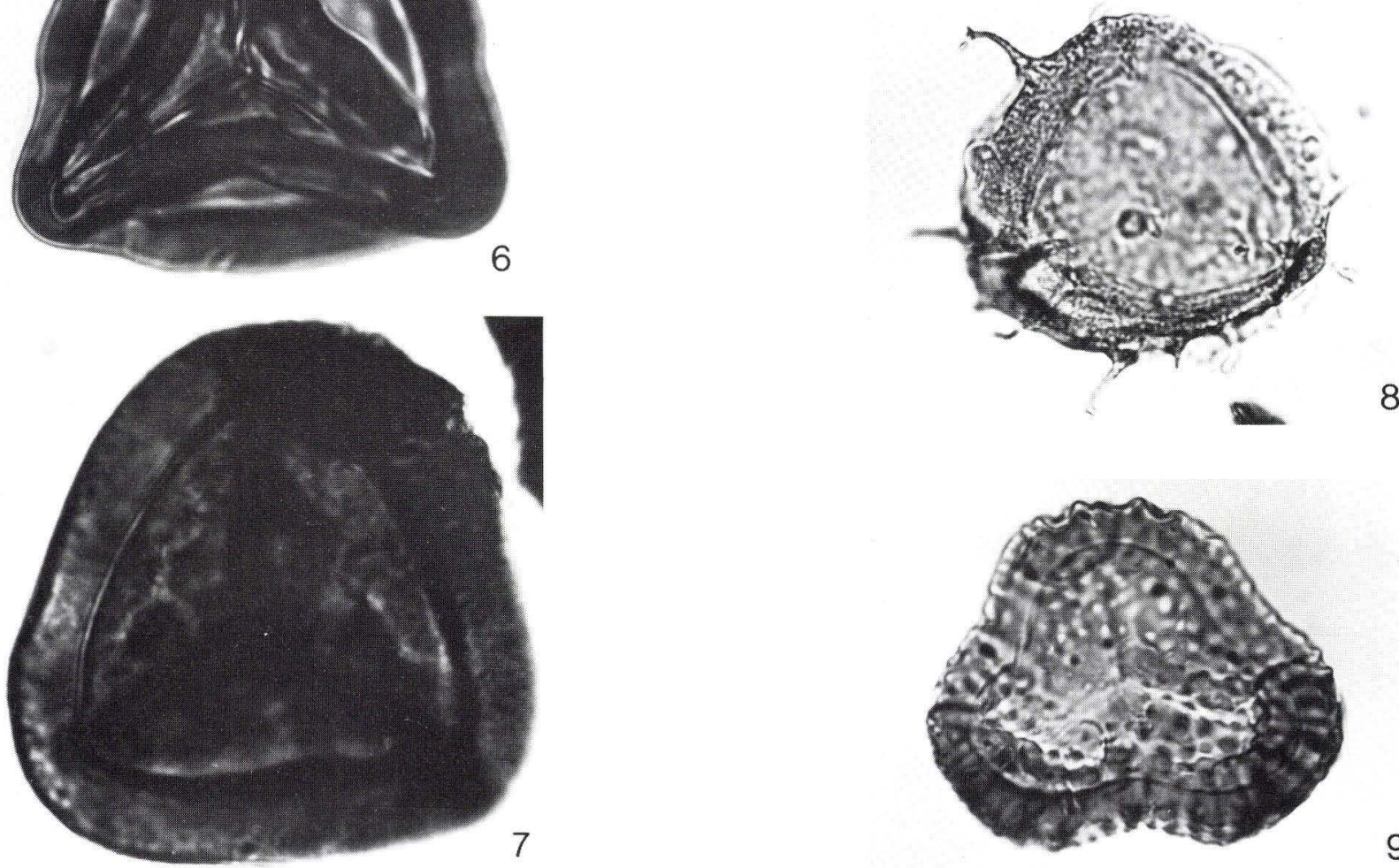


\section{PLATE 10}

Fig. 1. Contignisporites glebulentus Dettmann 1963 emend. Filatoff \& Price 1988. Presumed caved. Proximal side (high focus). Sample Frh-10,s.

Fig. 2. Same specimen as fig. 1. Distal side (low focus).

Fig. 3. Striatella jurassica Mädler 1964. Proximal side (low focus). Sample Frh-25,s.

Fig. 4. Same specimen as fig. 3. Distal side (high focus).

Fig. 5. Striatella seebergensis Mädler 1964 emend. Filatoff \& Price 1988. Sample St-10,c.

Fig. 6. Polycingulatisporites liassicus Schulz 1967. Proximal side (low focus). Sample St-18,w.

Fig. 7. Polycingulatisporites triangularis Playford \& Dettmann 1965. Proximal side (high focus). Sample St-5,c.

Fig. 8. Same specimen as fig. 7. Distal side (low focus).

Fig. 9. Same specimen as fig. 6. Distal side (high focus).

Fig. 10. Marattisporites scabratus Couper 1958. Sample Frh-8,c.

Fig. 11. Cf. Marattisporites sp. 1. Sample St-6,c. 
Plate 10
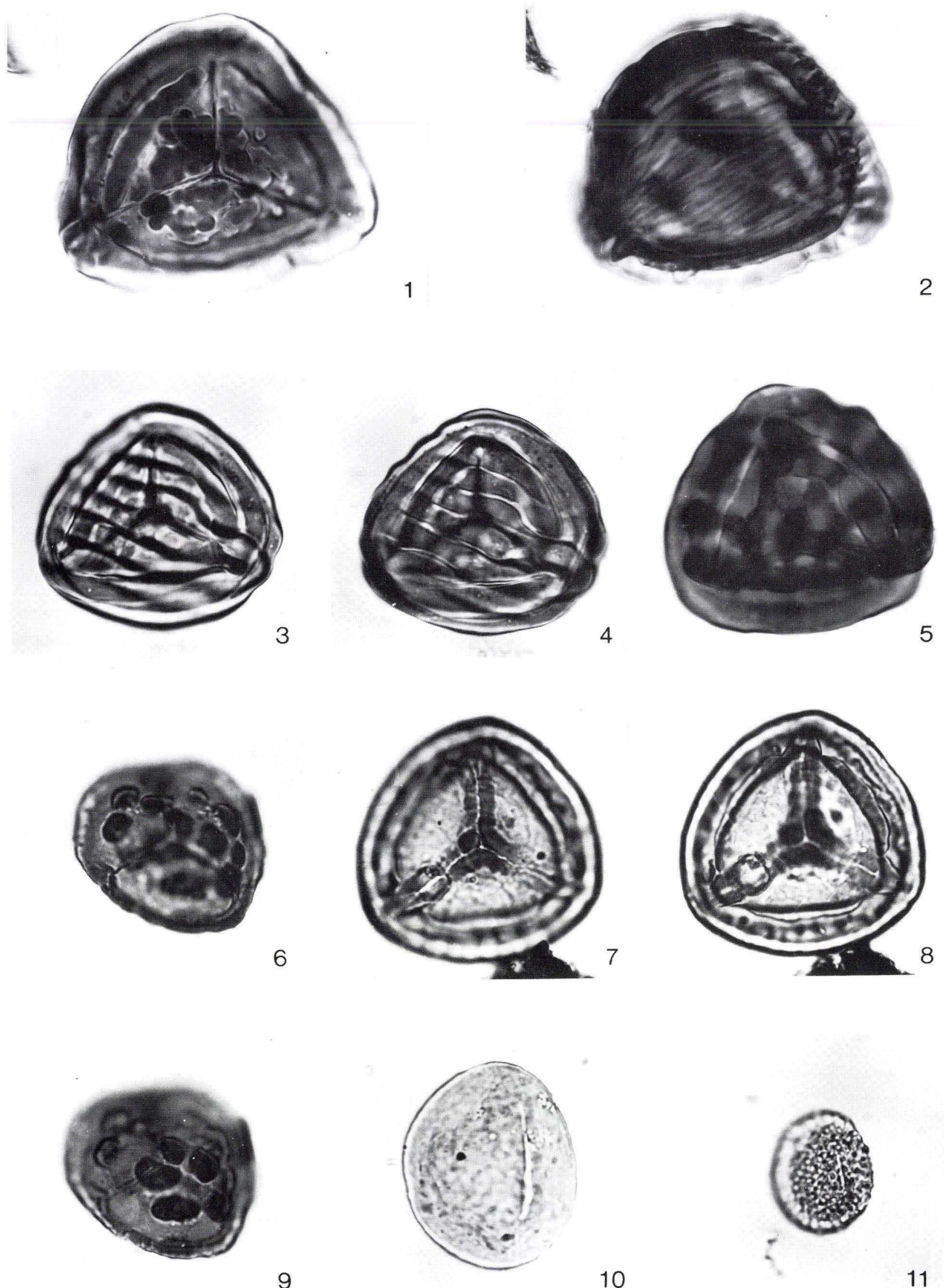


\section{PLATE 11}

Fig. 1. Aratrisporites minimus (Leschik 1955) Playford \& Dettmann 1965. Sample St-9,w.

Fig. 2. Aratrisporites fimbriatus (Klaus 1960) Playford \& Dettmann 1965. Sample St-3,c.

Fig. 3. Vitreisporites pallidus (Reissinger 1950) Nilsson 1958. Sample St-9,c.

Fig. 4. Vitreisporites bjuvensis Nilsson 1958. Sample St-3,c.

Fig. 5. Pinuspollenites minimus (Couper 1958) Kemp 1970. Sample St-7,c.

Fig. 6. Protopinus scanicus Nilsson 1958. Sample Frh-11,c.

Fig. 7. Pinuspollenites minimus (Couper 1958) Kemp 1970. Sample St-7,c.

Fig. 8. Alisporites robustus Nilsson 1958. Sample St-9,c.

Fig. 9. Parvisaccites radiatus Couper 1958. Presumed caved. Sample Frh-20,s.

Fig. 10. Ovalipollis ovalis Krutzsch 1955. Sampie St-2,c. 

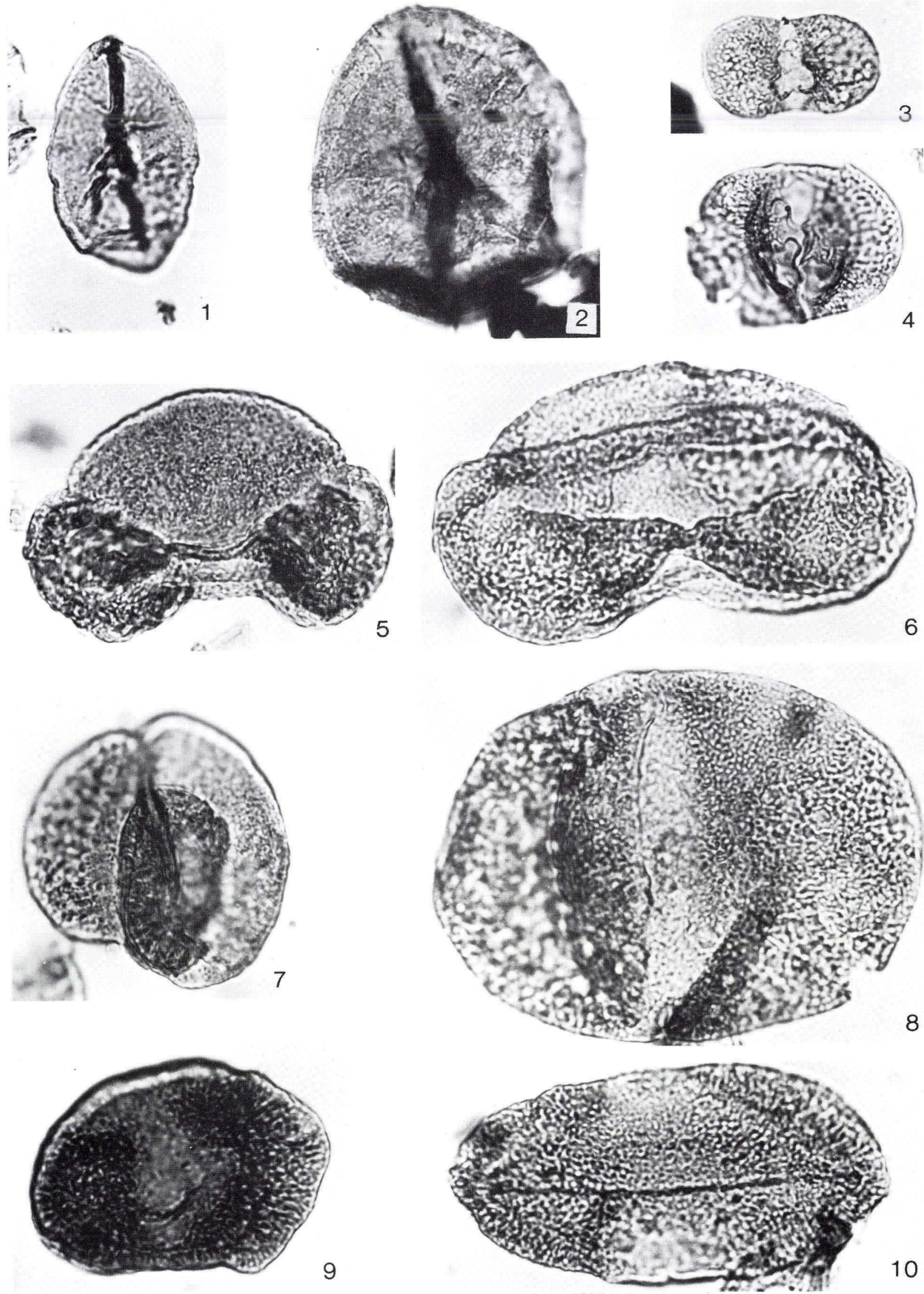


\section{PLATE 12}

Fig. 1. Quadraeculina anellaeformis Maljavkina 1949. Sample Frh-10,c.

Fig. 2. Umbrososaccus keuperianus Mädler 1964. Sample St-14,w.

Fig. 3. Taeneaesporites sp. Sample Fj-3,c.

Fig. 4. Perinopollenites elatoides Couper 1958. Sample Frh-9,c.

Fig. 5. Perinopollenites elatoides Couper 1958. Sample Frh-9,c.

Fig. 6. Perinopollenites elatoides Couper 1958. Loose innerbody. Sample Frh-8,c.

Fig. 7. Perinopollenites cf. elatoides Couper 1958. Sample Frh-9,c.

Fig. 8. Perinopollenites cf. elatoides Couper 1958. Broken velum. Sample Frh-12,c.

Fig. 9. Perinopollenites cf. elatoides Couper 1958. Loose innerbody. Sample Frh-9,c. 

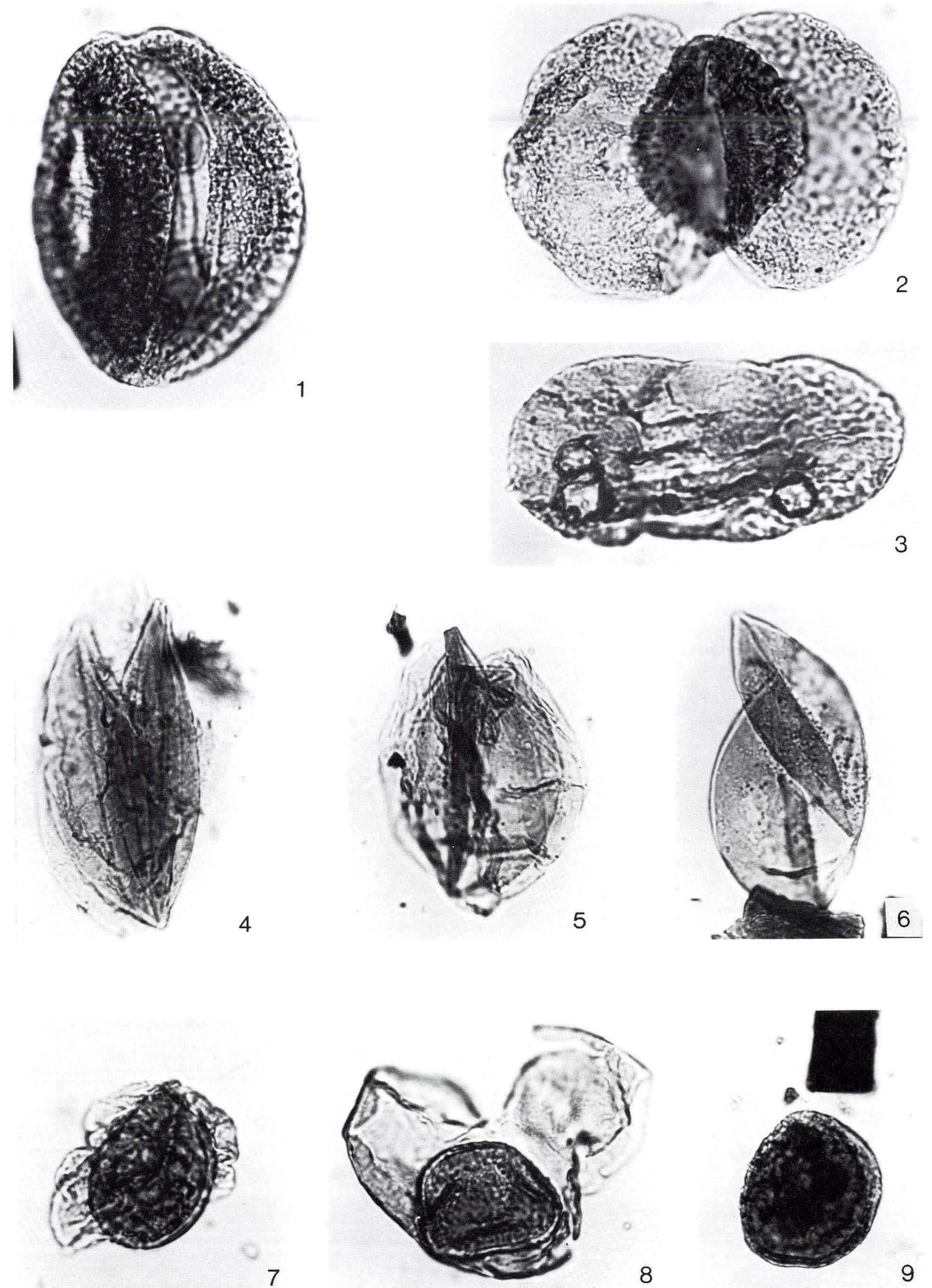


\section{PLATE 13}

Fig. 1. Cerebropollenites macroverrucosus (Thiergart 1949) Schulz 1967. Sample Fj-25,s.

Fig. 2. Cerebropollenites thiergartii Schulz 1967. Sample Frh-12,c.

Fig. 3. Cerebropollenites thiergartii Schulz 1967. Sample St-2,w.

Fig. 4. Cerebropollenites thiergartii Schulz 1967. Distinct sulcus. Proximal side (high focus). Sample Frh-17,c.

Fig. 5. Same specimen as fig. 4. Proximal side (low focus).

Fig. 6. Cerebropollenites thiergartii Schulz 1967. Distinct sulcus. Sample Frh-11,c.

Fig. 7. Spheripollenites psilatus Couper 1958. Cluster. NOTICE: Magnification x500. Sample Fj-31,s.

Fig. 8. Exesipollenites tumulus Balme 1957. Sample Fj-16,c. 

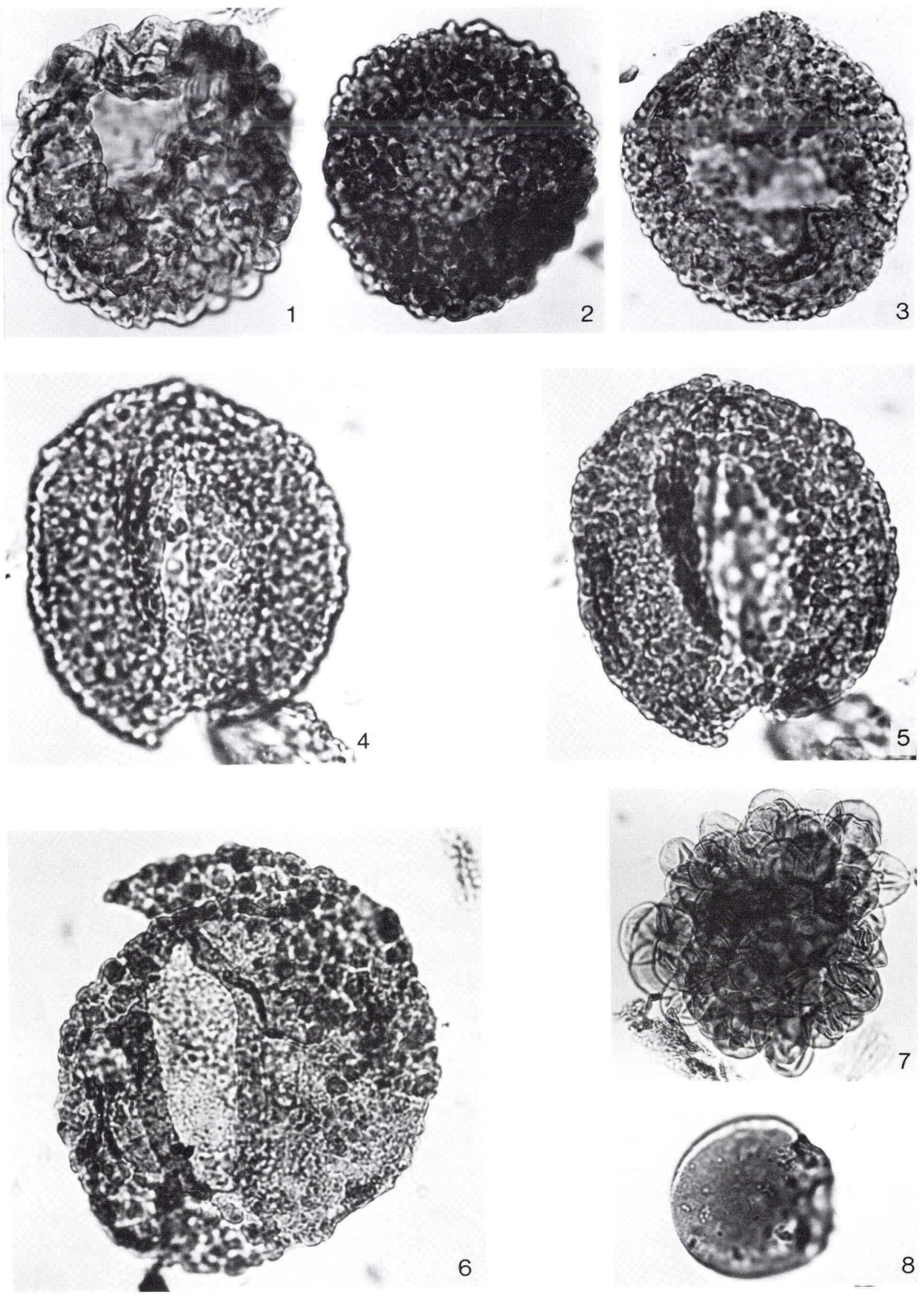
Fig. 1. Callialasporites trilobatus (Balme 1957) Dev 1961. Sample Frh-13,s.

Fig. 2. Callialasporites dampieri (Balme 1957) Dev 1961. Sample Frh-24,s.

Fig. 3. Chasmatosporites apertus (Rogalska 1954) Nilsson 1958. Sample Fj-30,s.

Fig. 4. Chasmatosporites hians Nilsson 1958. Proximal side (high focus). Sample Frh-7,c.

Fig. 5. Same specimen as fig. 4. Distal side (low focus).

Fig. 6. Chasmatosporites elegans Nilsson 1958. Sample St-7,w.

Fig. 7. Chasmatosporites major Nilsson 1958. Sample St-14,w.

Fig. 8. Ricciisporites tuberculatus Lundblad 1954. Tetrad. NOTICE: Magnification x500. Sample St-2,c.

Fig. 9. Riccisporites tuberculatus Lundblad 1954. Single grain. Sample St-3,c. 

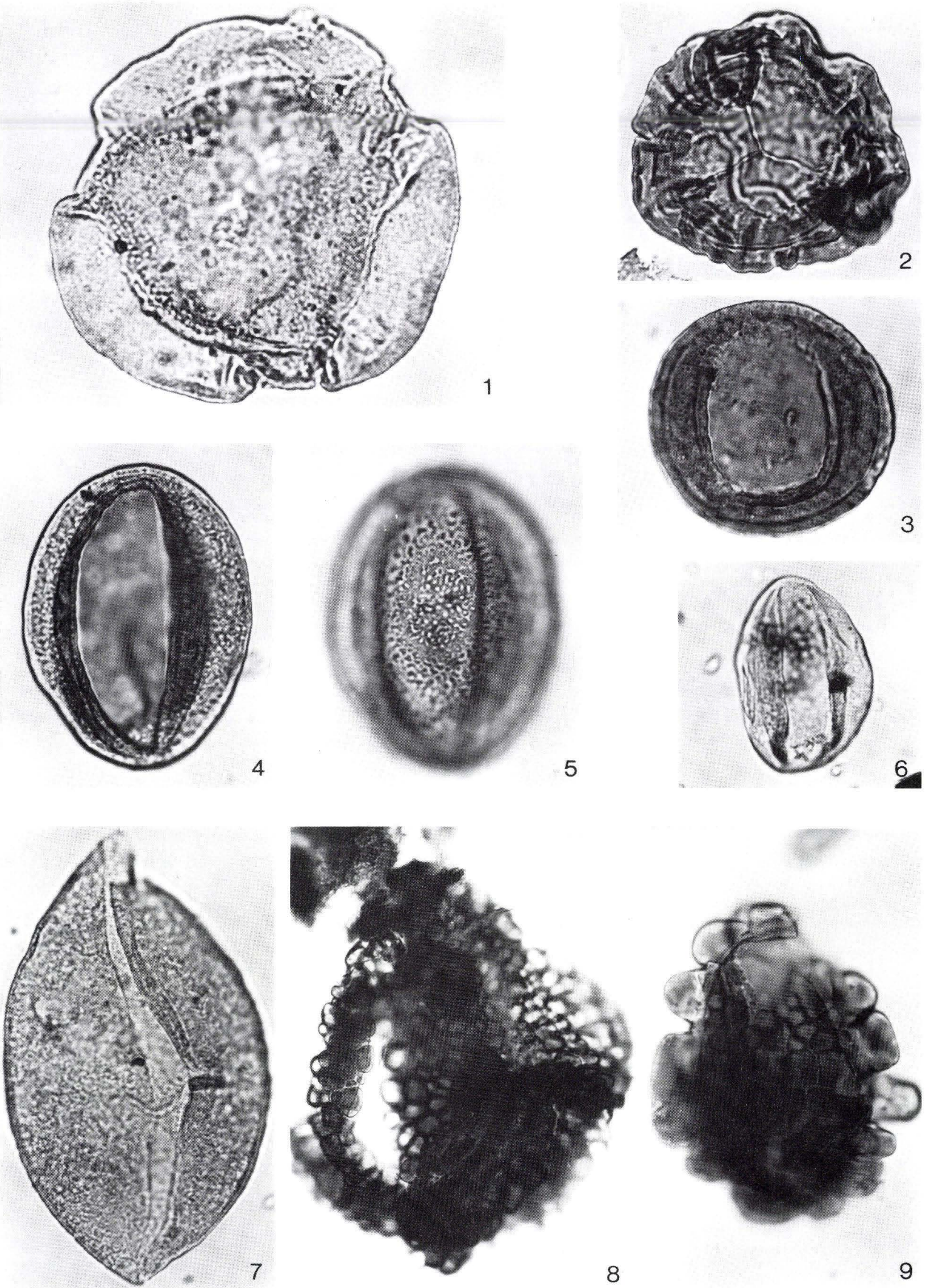


\section{PLATE 15}

Fig. 1. Monosulcites minimus Couper 1958. Sample Fj-21,s.

Fig. 2. Corollina torosus (Reissinger 1950) Klaus 1960. Tetrad. High focus. Sample Fj-33,s.

Fig. 3. Same specimen as fig. 2. Low focus.

Fig. 4. Corollina torosus (Reissinger 1950) Klaus 1960. Single grain. Sample St-11,c.

Fig. 5. Corollina torosus (Reissinger 1950) Klaus 1960. Single grain. Sample Fj-2,c.

Fig. 6. Corollina cf. meyeriana (Klaus 1960) Venkatachảla \& Góznan 1964. Sample Frh-12,c.

Fig. 7. Corollina cf. meyeriana (Klaus 1960) Venkatachala \& Góznan 1964. Sample St-13,w.

Fig. 8. Nannoceratopsis gracilis (Alberti 1961) van Helden 1977. Sample Frh-22,c.

Fig. 9. Nannoceratopsis cf. senex van Helden 1977. Sample Frh-22,c.

Fig. 10. Nannoceratopsis sp. 1. Sample St-14,w.

Fig. 11. Nannoceratopsis cf. pellucida (Deflandre 1938) Evitt 1961. High focus. Sample Fj-15,c.

Fig. 12. Same specimen as fig. 11. Low focus.

Fig. 13. Dapcodinium priscum (Evitt 1961) Below 1987. Sample Fj-5,c. 
Plate 15
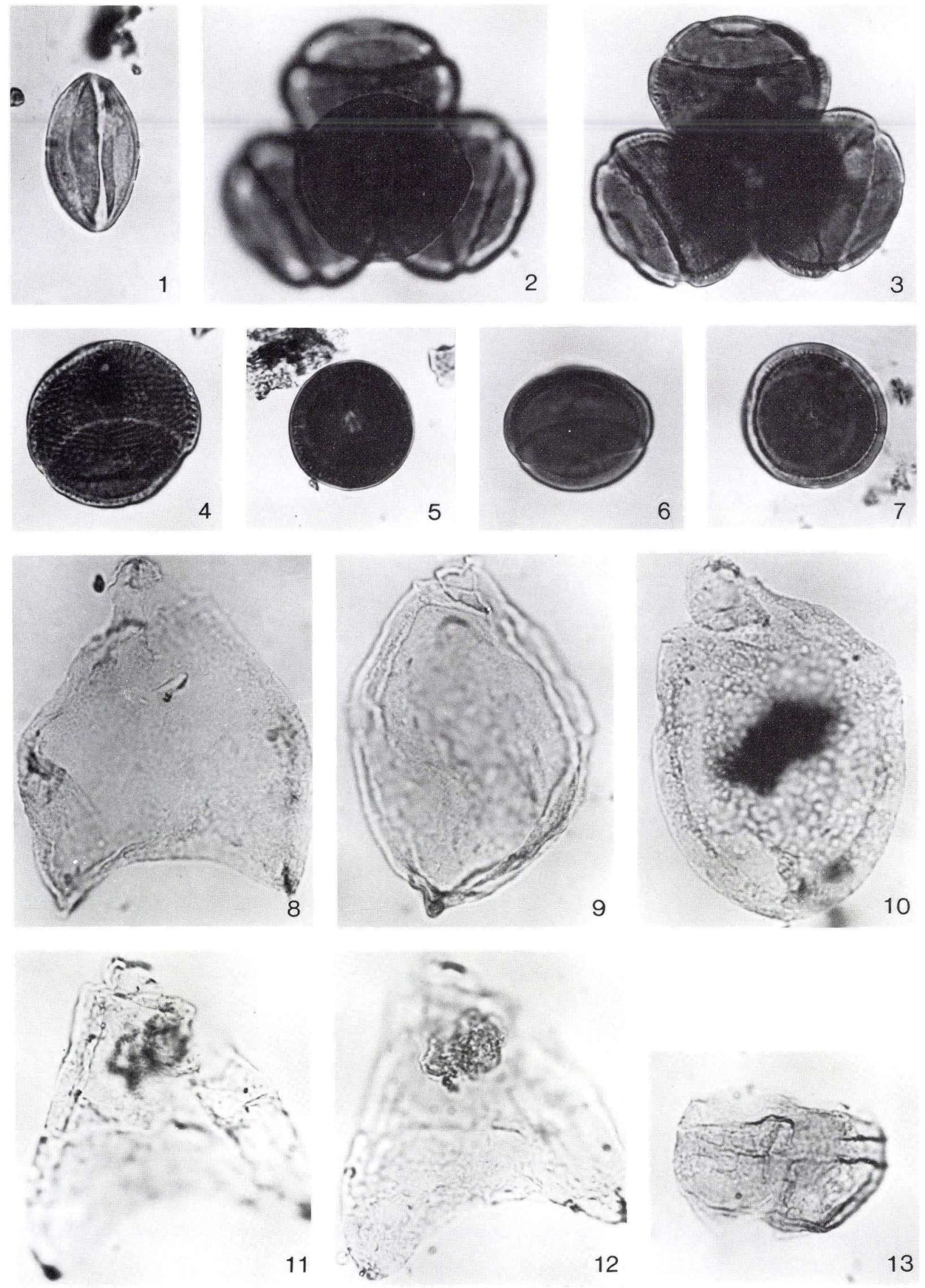
Fig. 1. Dapcodinium priscum (Evitt 1961) Below 1987. High focus. Sample St-6,c.

Fig. 2. Same specimen as fig. 1. Low focus.

Fig. 3. Liasidium variabile Drugg 1978. Sample Fj-9,s.

Fig. 4. Rhaetogonyaulax rhaetica (Sarjeant 1963) Below 1987. Sample Fj-2,c.

Fig. 5. Rhaetogonyaulax rhaetica (Sarjeant 1963) Below 1987. Sample St-2,c.

Fig. 6. Liasidium variabile Drugg 1978. Sample Fj-9,s.

Fig. 7. Escharisphaeridia pococki (Sarjeant 1968) Erkman \& Sarjeant 1980. High focus. Sample Fj-16,c.

Fig. 8. Same specimen as fig. 7. Low focus.

Fig. 9. Escharisphaeridia sp. Sample St-13,w. 
Plate 16
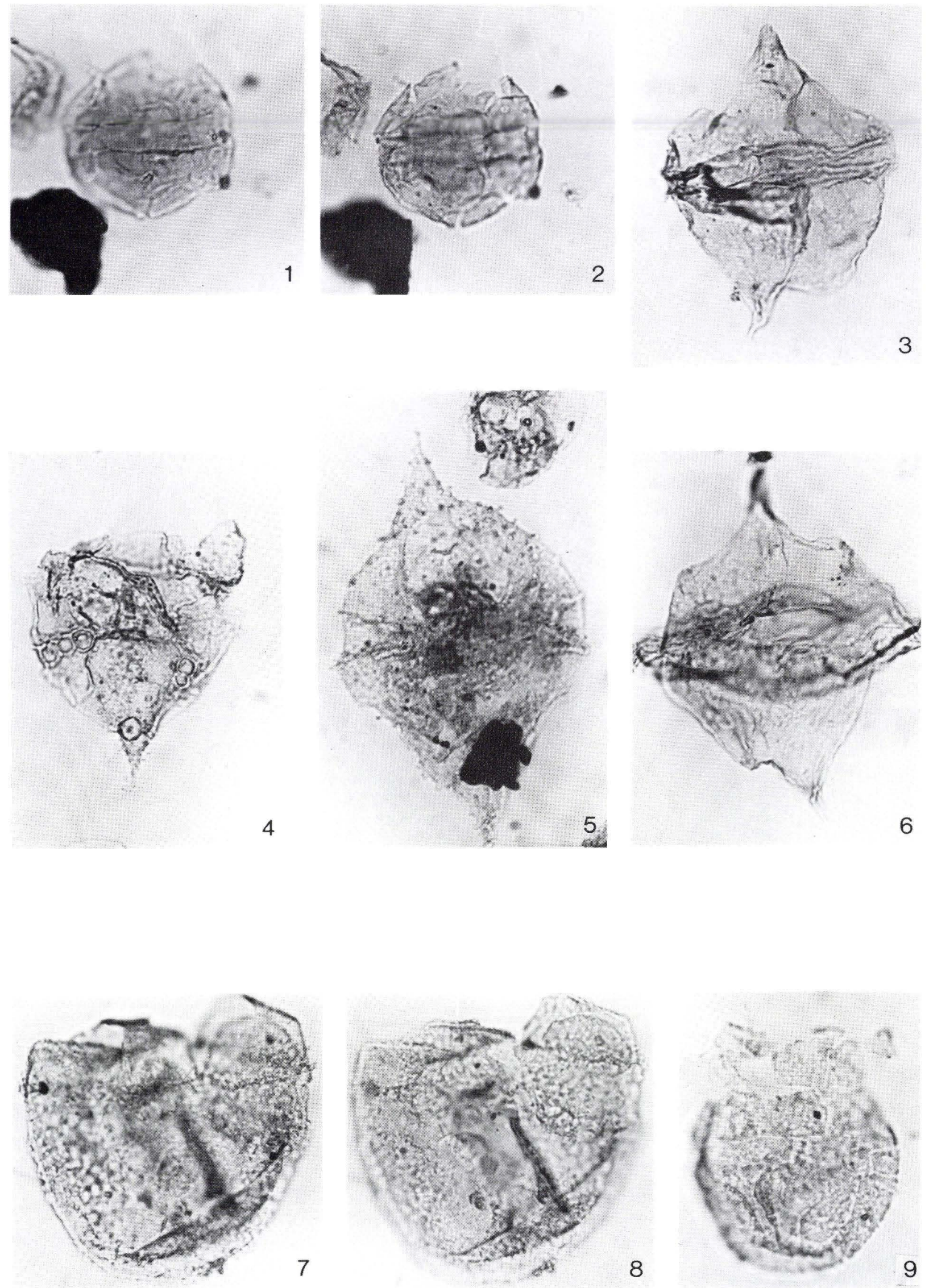


\section{PLATE 17}

Fig. 1. Dinocyst sp. 1. Sample Frh-19,c.

Fig. 2. Prolixosphaeridium sp. Sample Frh-14,c.

Fig. 3. Odontochitina cf. operculata Deflandre 1947. Presumed caved. NOTICE: Magnification x500. Sample Frh-11,s.

Fig. 4. Sirmiodinium grossii Alberti 1961. Presumed caved. High focus. Sample Frh-11,s.

Fig. 5. Same specimen as fig. 4. Low focus. 

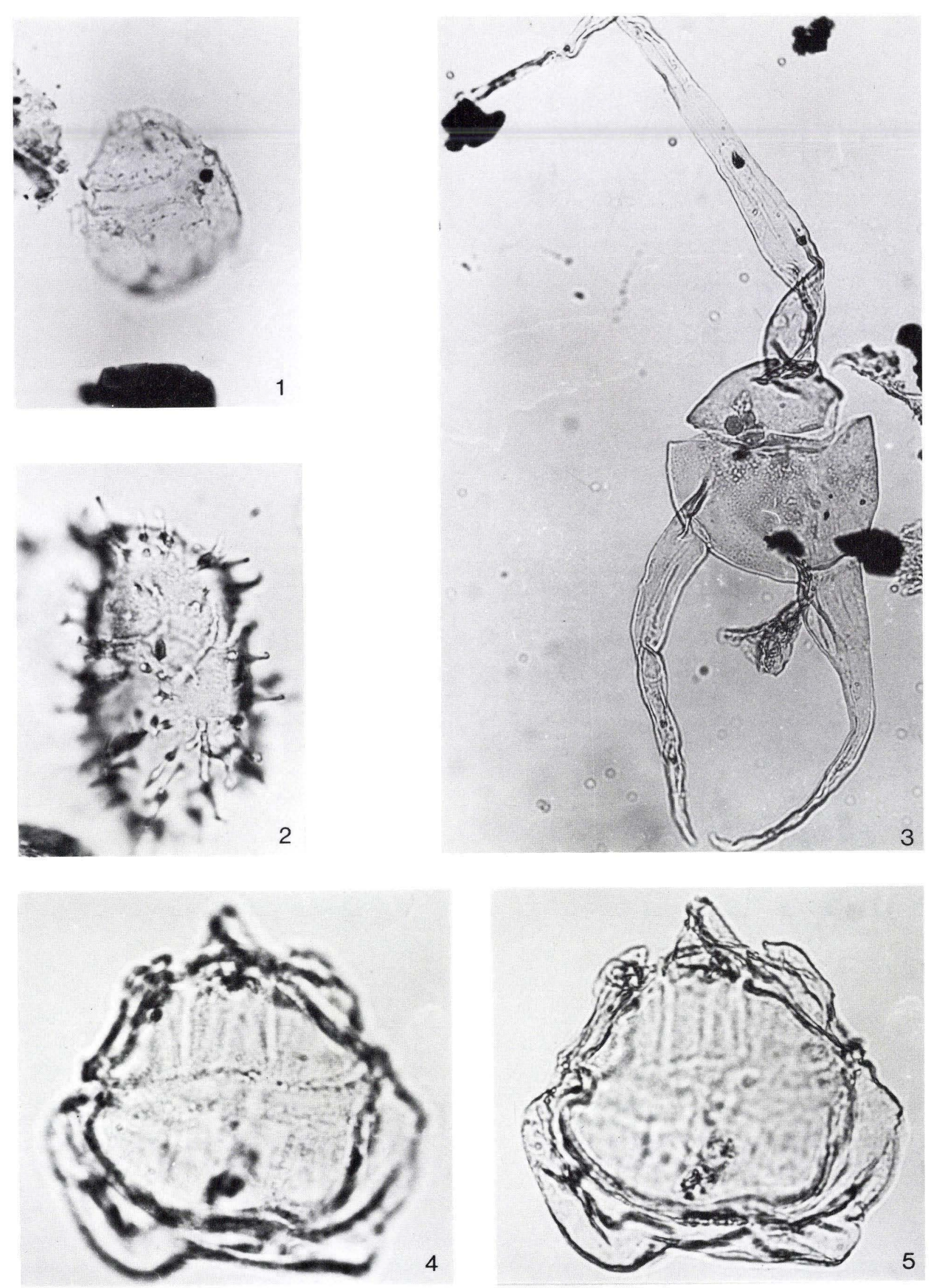
Fig. 1. Kleithriasphaeridium cf. readei (Davey \& Williams 1966) Davey \& Verdier 1976. Presumed caved. Sample Frh-10,s. Fig. 2. Protoellipsodinium spinosum Davey \& Verdier 1971. Presumed caved. High focus. Sample Frh-20,s.

Fig. 3. Same specimen as fig. 2. Low focus.

Fig. 4. Spiniferites ramosus (Ehrenberg 1838) Loeblich \& Loeblich 1966. Presumed caved. Sample Frh-20,s.

Fig. 5. Sphaeromorphitae, type 1. Sample St-2,c.

Fig. 6. Sphaeromorphitae, type 2. Sample St-2,w.

Fig. 7. Acanthomorphitae, type 1. Sample Fj-19,s.

Fig. 8. Acanthomorphitae, type 2. Sample St-11,w.

Fig. 9. Acanthomorphitae, type 3. Sample St-11,w. 



6 
Fig. 1. Acanthomorphitae, type 4. Sample Fj-21,s.

Fig. 2. Veryhachium sp. Sample Fj-16,c.

Fig. 3. Leiofusa jurassica Cookson \& Eisenack 1958. Sample St-8,c.

Fig. 4. Polygonomorphitae, type 1. Sample Fj-5,s.

Fig. 5. Polygonomorphitae, type 2. Sample St-7,c.

Fig. 6. Polygonomorphitae, type 3. Sample St-7,c.

Fig. 7. Cymatiosphaera, type 1. Sample St-11,w.

Fig. 8. Diexallophasis denticulata (Stockmans \& Williére 1963) Loeblich 1970. Presumed reworked. Sample St-17,w.

Fig. 9. Multiplicisphaeridium sp. Presumed reworked. Sample Frh-19,c.

Fig. 10. Species indet, type 1. Sample Frh-13,c. 
Plate 19
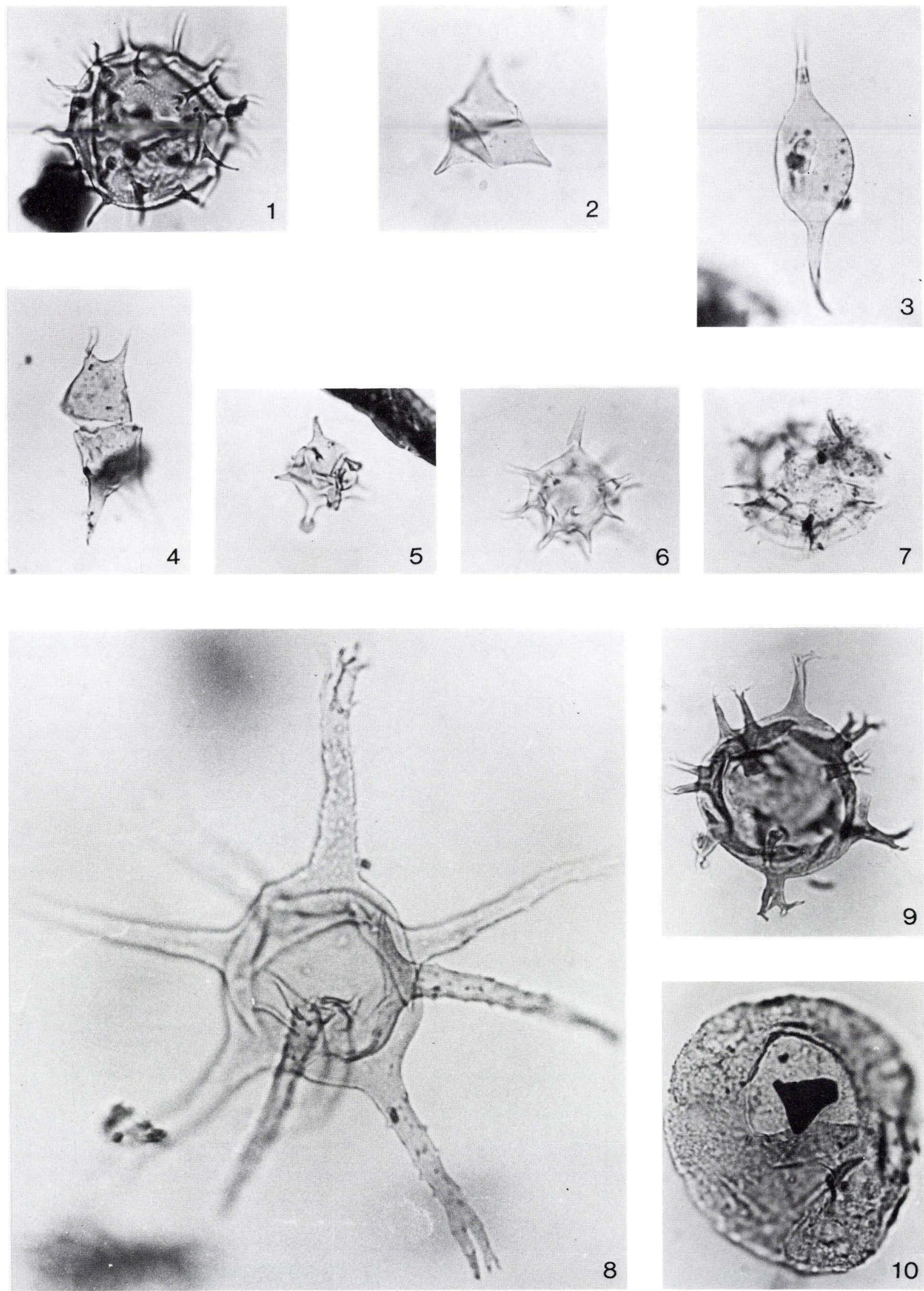
Fig. 1. Botryococcus sp. Sample St-14,w.

Fig. 2. Cymatiosphaera, type 2. Sample Fj-32,s.

Fig. 3. Schizocystia rara Playford \& Dettmann 1965. Sample Frh-15,c.

Fig. 4. Schizosporis reticulatus Cookson \& Dettmann 1959. NOTICE: Magnification x250. Sample Frh-18,c.

Fig. 5. Foraminiferal test-lining. Sample Fj-31,s.

Fig. 6. Fungal spores. Sample St-9,w.

Fig. 7. Species indet., type 2. High focus. Sample Frh-16,c.

Fig. 8. Same specimen as fig. 7. Low focus. 


Fig. 1. Trachysporites fuscus Nilsson 1958. The holotype. Proximal side (high focus).

Fig. 2. Trachysporites tuberosum Nilsson 1958. The holotype. Junior synonym to Trachysporites fuscus Nilsson 1958.

Fig. 3. Trachysporites asper Nilsson 1958. The holotype.

Fig. 4. Same specimen as fig. 1. Proximal side (lower focus).

Fig. 5. Apiculatisporites ovalis (Nilsson 1958) Norris 1964. The holotype. (Formerly Acanthotriletes ovalis Nilsson 1958). Proximal side (high focus).

Fig. 6. Same specimen as fig. 5. Proximal side (lower focus).

Fig. 7. Same specimen as figs 1 and 4. Distal side (low focus).

Fig. 8. Acanthotriletes trigonus Nilsson 1958. The holotype. Junior synonym to Apiculatisporites ovalis (Nilsson 1958) Norris 1964. 
Plate 21

PLATE 22

Fig. 1. Vitreisporites bjuvensis Nilsson 1958. The holotype. Distal side (high focus).

Fig. 2. Same specimen as fig. 1. Distal side (lower focus).

Fig. 3. Alisporites robustus Nilsson 1958. The holotype. Proximal side (high focus).

Fig. 4. Same specimen as fig. 3. Distal side (low focus).

Fig. 5. Schismatosporites ovalis Nilsson 1958. The holotype. Lateral view. NOTICE: Magnification x800.

Fig. 6. Chasmatosporites elegans Nilsson 1958. The holotype. 
Plate 22



\section{Appendix A \\ The Fjerritslev-2 borehole}

Sample litholgy

\begin{tabular}{|c|c|c|c|c|}
\hline $\begin{array}{l}\text { Lithostrat. } \\
\text { units }\end{array}$ & $\begin{array}{c}\text { Sample } \\
\text { no. }\end{array}$ & $\begin{array}{c}\text { Depth } \\
\text { (m.b.r.t.) }\end{array}$ & $\begin{array}{l}\text { Sample } \\
\text { lithology }\end{array}$ & T.O.C. \\
\hline F-IV Mb. & FJ-16,c & 1329 & si.cl.st. $\xi$ & 1.5 \\
\hline \multirow[t]{2}{*}{ F-III Mb. } & FJ-15,c & 1561 & si.cl.st. & 1.5 \\
\hline & FJ-14,c & 1563 & si.cl.st. & 1.4 \\
\hline \multirow[t]{5}{*}{ F-Ib Mb. } & FJ-13,c & 2001 & si.cl.st. & 0.9 \\
\hline & FJ-12,c & 2003 & si.cl.st. & 0.6 \\
\hline & FJ-11,c & 2084 & si.cl.st. $\xi$ & 0.7 \\
\hline & $\mathrm{FJ}-10, \mathrm{c}$ & 2085 & si.cl.st. & 0.7 \\
\hline & FJ- 9,c & 2087 & si.cl.st. & 0.8 \\
\hline \multirow[t]{6}{*}{ F-Ia Mb. } & FJ- 8,c & 2102 & si.cl.st. & 0.8 \\
\hline & FJ- 7,c & 2103 & si.cl.st. & 0.8 \\
\hline & FJ- $6, c$ & 2104 & si.cl.st. & 0.9 \\
\hline & FJ- $5, c$ & 2105 & clayst. & 1.0 \\
\hline & FJ- $4, c$ & 2106 & clayst. & 1.1 \\
\hline & FJ- 3,c & 2303 & cl.sa.st. & 0.9 \\
\hline Gassum & FJ- $2, \mathrm{c}$ & 2304 & sa.cl.st. & 1.0 \\
\hline Fm. & FJ- 1,c & 2305 & cl.sa.st. & 0.9 \\
\hline
\end{tabular}

$\xi$ : burrows

clayst.: claystone

si.cl.st.: silt-streaked claystone

sa.cl.st.: sand-streaked claystone

cl.sa.st.: clay-streaked sandstone

Brown wood, size groups, relative abundances

$100 \%=$ total of brown wood

\begin{tabular}{lcccc}
\hline $\begin{array}{l}\text { Sample } \\
\text { no. }\end{array}$ & $\begin{array}{c}<20 \\
\text { microns } \\
\%\end{array}$ & $\begin{array}{c}20-80 \\
\text { microns } \\
\%\end{array}$ & $\begin{array}{c}>80 \\
\text { microns } \\
\%\end{array}$ & Total \\
\hline FJ-16,c & 36 & 61 & 3 & 100 \\
FJ-15,c & 30 & 67 & 3 & 100 \\
FJ-14,c & 31 & 66 & 3 & 100 \\
FJ-13,c & 11 & 84 & 5 & 100 \\
FJ-12,c & 23 & 74 & 3 & 100 \\
FJ-11,c & 30 & 68 & 2 & 100 \\
FJ-10,c & 24 & 74 & 2 & 100 \\
FJ- 9,c & 34 & 63 & 3 & 100 \\
FJ- 8,c & 25 & 72 & 3 & 100 \\
FJ- 7,c & 29 & 69 & 3 & 100 \\
FJ- 6,c & 25 & 70 & 4 & 100 \\
FJ- 5,c & 23 & 74 & 3 & 100 \\
FJ- 4,c & 25 & 71 & 4 & 100 \\
FJ- 3,c & 22 & 75 & 3 & 100 \\
FJ- 2,c & 9 & 86 & 5 & 100 \\
FJ- 1,c & 34 & 65 & 1 & 100 \\
\hline
\end{tabular}

Kerogen categories

Relative abundances

\begin{tabular}{lcccccc}
\hline Sample & $\begin{array}{c}\text { Paly- } \\
\text { nom. } \\
\%\end{array}$ & $\begin{array}{c}\text { Br. } \\
\text { wood } \\
\%\end{array}$ & $\begin{array}{c}\text { Bl. } \\
\text { wood } \\
\%\end{array}$ & $\begin{array}{c}\text { Cuticle } \\
\text { no. }\end{array}$ & $\begin{array}{l}\% \\
\text { F.O.M. }\end{array}$ & Total \\
\hline FJ-16,c & 23 & 56 & 13 & 1 & 7 & 100 \\
FJ-15,c & 43 & 32 & 7 & 0 & 18 & 100 \\
FJ-14,c & 43 & 31 & 5 & 0 & 20 & 100 \\
FJ-13,c & 25 & 55 & 18 & 0 & 2 & 100 \\
FJ-12,c & 21 & 55 & 23 & 1 & 1 & 100 \\
FJ-11,c & 22 & 66 & 12 & 0 & 0 & 100 \\
FJ-10,c & 18 & 69 & 13 & 0 & 0 & 100 \\
FJ- 9,c & 12 & 71 & 16 & 0 & 1 & 100 \\
FJ- 8,c & 18 & 73 & 8 & 0 & 2 & 100 \\
FJ- 7,c & 15 & 75 & 8 & 0 & 2 & 100 \\
FJ- 6,c & 13 & 72 & 12 & 0 & 3 & 100 \\
FJ- 5,c & 17 & 74 & 8 & 0 & 1 & 100 \\
FJ- 4,c & 4 & 83 & 9 & 0 & 3 & 100 \\
FJ- 3,c & 8 & 67 & 23 & 0 & 1 & 100 \\
FJ- 2,c & 11 & 76 & 11 & 0 & 2 & 100 \\
FJ- 1,c & 0 & 77 & 23 & 0 & 0 & 100 \\
\hline
\end{tabular}

Black wood, size groups, relative abundances $100 \%=$ total of black wood

\begin{tabular}{lcccc}
\hline $\begin{array}{l}\text { Sample } \\
\text { no. }\end{array}$ & $\begin{array}{c}<20 \\
\text { microns } \\
\%\end{array}$ & $\begin{array}{c}20-80 \\
\text { microns } \\
\%\end{array}$ & $\begin{array}{c}>80 \\
\text { microns } \\
\%\end{array}$ & Total \\
\hline FJ-16,c & 22 & 78 & 0 & 100 \\
FJ-15,c & 43 & 52 & 5 & 100 \\
FJ-14,c & 20 & 80 & 0 & 100 \\
FJ-13,c & 14 & 80 & 6 & 100 \\
FJ-12,c & 13 & 86 & 1 & 100 \\
FJ-11,c & 11 & 86 & 3 & 100 \\
FJ-10,c & 21 & 79 & 0 & 100 \\
FJ- 9,c & 26 & 73 & 1 & 100 \\
FJ- 8,c & 25 & 73 & 2 & 100 \\
FJ- 7,c & 38 & 63 & 0 & 100 \\
FJ- 6,c & 30 & 68 & 1 & 100 \\
FJ- 5,c & 11 & 89 & 0 & 100 \\
FJ- 4,c & 38 & 56 & 6 & 100 \\
FJ- 3,c & 26 & 70 & 4 & 100 \\
FJ- 2,c & 8 & 90 & 2 & 100 \\
FJ- 1,c & 38 & 61 & 1 & 100 \\
\hline
\end{tabular}




\begin{tabular}{|c|c|c|c|c|c|c|c|c|c|c|c|c|}
\hline $\begin{array}{l}\text { Sample } \\
\text { no. }\end{array}$ & $\begin{array}{l}\text { Palyno- } \\
\text { morphs }\end{array}$ & $\begin{array}{c}\text { Brown } \\
\text { wood }\end{array}$ & $\begin{array}{l}<20 \\
\text { microns }\end{array}$ & $\begin{array}{c}20-80 \\
\text { microns }\end{array}$ & $\begin{array}{l}\quad>80 \\
\text { microns }\end{array}$ & $\begin{array}{l}\text { Black } \\
\text { wood }\end{array}$ & $\begin{array}{c}<20 \\
\text { microns }\end{array}$ & $\begin{array}{c}20-80 \\
\text { microns }\end{array}$ & $\begin{array}{l}\quad>80 \\
\text { microns }\end{array}$ & Cuticle & A.O.M & $\mathrm{n}$ \\
\hline FJ-16,c & 139 & 329 & 119 & 201 & 9 & 77 & 17 & 60 & 0 & 4 & 43 & 592 \\
\hline $\mathrm{FJ}-15, \mathrm{c}$ & 252 & 189 & 56 & 127 & 6 & 44 & 19 & 23 & 2 & 0 & 104 & 589 \\
\hline FJ-14,c & 242 & 176 & 55 & 116 & 5 & 30 & 6 & 24 & 0 & 1 & 110 & 559 \\
\hline $\mathrm{FJ}-13, \mathrm{c}$ & 137 & 294 & 32 & 246 & 16 & 95 & 13 & 76 & 6 & 1 & 12 & 539 \\
\hline $\mathrm{FJ}-12, \mathrm{c}$ & 111 & 297 & 68 & 219 & 10 & 125 & 16 & 108 & 1 & 3 & 3 & 539 \\
\hline $\mathrm{FJ}-11, \mathrm{c}$ & 113 & 346 & 104 & 235 & 7 & 63 & 7 & 54 & 2 & 0 & 1 & 523 \\
\hline FJ-10,c & 111 & 419 & 102 & 310 & 7 & 78 & 16 & 62 & 0 & 1 & 1 & 610 \\
\hline FJ- $9, c$ & 67 & 393 & 134 & 248 & 11 & 89 & 23 & 65 & 1 & 0 & 3 & 552 \\
\hline FJ- $8, \mathrm{c}$ & 97 & 401 & 99 & 288 & 14 & 44 & 11 & 32 & 1 & 0 & 11 & 553 \\
\hline FJ- $7, \mathrm{c}$ & 83 & 424 & 122 & 291 & 11 & 48 & 18 & 30 & 0 & 0 & 14 & 569 \\
\hline FJ- $6, c$ & 75 & 420 & 106 & 296 & 18 & 69 & 21 & 47 & 1 & 2 & 18 & 584 \\
\hline FJ- $5, \mathrm{c}$ & 94 & 421 & 97 & 312 & 12 & 44 & 5 & 39 & 0 & 1 & 6 & 566 \\
\hline $\mathrm{FJ}-4, \mathrm{c}$ & 24 & 461 & 114 & 327 & 20 & 52 & 20 & 29 & 3 & 0 & 19 & 556 \\
\hline FJ- 3,c & 45 & 359 & 79 & 268 & 12 & 123 & 32 & 86 & 5 & 1 & 7 & 535 \\
\hline $\mathrm{FJ}-2, \mathrm{c}$ & 62 & 414 & 37 & 358 & 19 & 60 & 5 & 54 & 1 & 0 & 11 & 547 \\
\hline FJ $-1, \mathrm{c}$ & 0 & 398 & 134 & 259 & 5 & 122 & 46 & 75 & 1 & 0 & 0 & 520 \\
\hline
\end{tabular}

\begin{tabular}{lccc}
\hline $\begin{array}{l}\text { Sample } \\
\text { no. }\end{array}$ & PhytOC & AmexOC & $\begin{array}{c}\text { Marine } \\
\text { palynom. \% }\end{array}$ \\
\hline FJ-16,c & 1.03 & 0.11 & 11 \\
FJ-15,c & 0.57 & 0.26 & 24 \\
FJ-14,c & 0.50 & 0.27 & - \\
FJ-13,c & 0.66 & 0.02 & - \\
FJ-12,c & 0.50 & 0.00 & 25 \\
FJ-11,c & 0.54 & 0.00 & 14 \\
FJ-10,c & 0.56 & 0.00 & - \\
FJ- 9,c & 0.72 & 0.00 & 20 \\
FJ- 8,c & 0.64 & 0.02 & - \\
FJ- 7,c & 0.66 & 0.02 & 5 \\
FJ- 6,c & 0.72 & 0.03 & - \\
FJ- 5,c & 0.83 & 0.01 & 1 \\
FJ- 4,c & 0.97 & 0.04 & 7 \\
FJ- 3,c & 0.82 & 0.01 & 9 \\
FJ- 2,c & 0.89 & 0.02 & 22 \\
FJ- 1,c & 0.85 & 0.00 & - \\
\hline
\end{tabular}

PhytOC $=(\%$ brown wood $+\%$ black wood $+\%$ cuticle $) \times$ T.O.C. AmexOC $=\%$ Amorphous Organic Matter (A.O.M.) $\times$ T.O.C.

Terrestrial palynomorphs Relative abundances

\begin{tabular}{lccccc}
\hline Sample & Spores & $\begin{array}{c}\text { Saccate } \\
\text { pollen }\end{array}$ & $\begin{array}{c}\text { Non- } \\
\text { saccate } \\
\text { pollen }\end{array}$ & $\begin{array}{c}\text { Total } \\
\text { spores } \\
\text { pollen }\end{array}$ & $\begin{array}{c}\text { Ratio: } \\
\text { saccate } \\
\text { pollen/ } \\
\text { spores }\end{array}$ \\
\hline & & $\%$ & $\%$ & $\%$ & \\
FJ-16,c & 20 & 14 & 66 & 100 & 0.71 \\
FJ-15,c & 8 & 17 & 75 & 100 & 2.09 \\
FJ-14,c & - & - & - & - & - \\
FJ-13,c & - & - & - & - & - \\
FJ-12,c & 23 & 34 & 42 & 100 & 1.47 \\
FJ-11,c & 33 & 26 & 41 & 100 & 0.78 \\
FJ-10,c & - & - & - & - & - \\
FJ- 9,c & 40 & 12 & 48 & 100 & 0.31 \\
FJ- 8,c & - & - & - & - & - \\
FJ- 7,c & 37 & 15 & 48 & 100 & 0.40 \\
FJ- 6,c & - & - & - & - & - \\
FJ- 5,c & 38 & 28 & 35 & 100 & 0.74 \\
FJ- 4,c & 56 & 15 & 29 & 100 & 0.27 \\
FJ- 3,c & 37 & 7 & 56 & 100 & 0.20 \\
FJ- 2,c & 33 & 8 & 59 & 100 & 0.23 \\
FJ- 1,c & - & - & - & - & - \\
\hline
\end{tabular}

$\%$ marine palynomorphs: $100 \%=$ total palynomorphs 
Aquatic palynomorphs

Relative abundances

\begin{tabular}{|c|c|c|c|c|c|c|c|c|}
\hline $\begin{array}{l}\text { Sample } \\
\text { no. }\end{array}$ & $\begin{array}{c}\text { Dinofl. } \\
\text { cysts } \\
\%\end{array}$ & $\begin{array}{c}\text { Acri- } \\
\text { tarchs } \\
\%\end{array}$ & $\begin{array}{c}\text { Tasma- } \\
\text { naceae } \\
\%\end{array}$ & $\begin{array}{c}\text { Ptero- } \\
\text { sperm. } \\
\quad \%\end{array}$ & $\begin{array}{c}\text { Cymat. } \\
\text { sphera. } \\
\%\end{array}$ & $\begin{array}{c}\text { Foram. } \\
\text { testl. } \\
\quad \%\end{array}$ & $\begin{array}{c}\text { Limnic } \\
\text { algae } \\
\%\end{array}$ & $\begin{array}{c}\text { Total } \\
\text { aquat. } \\
\text { palyn. } \\
\%\end{array}$ \\
\hline FJ-16,c & 13 & 75 & 9 & 0 & 0 & 0 & 3 & 100 \\
\hline FJ-15,c & 8 & 86 & 0 & 2 & 3 & 0 & 1 & 100 \\
\hline FJ-14,c & - & - & - & - & - & - & - & - \\
\hline $\mathrm{FJ}-13, \mathrm{c}$ & - & - & - & - & - & - & - & - \\
\hline $\mathrm{FJ}-12, \mathrm{c}$ & 20 & 80 & 0 & 0 & 0 & 0 & 0 & 0 \\
\hline $\mathrm{FJ}-11, \mathrm{c}$ & 0 & 100 & 0 & 0 & 0 & 0 & 0 & 0 \\
\hline FJ-10,c & - & - & - & - & - & - & - & - \\
\hline FJ- 9,c & 0 & 100 & 0 & 0 & 0 & 0 & 0 & 0 \\
\hline FJ- $8, \mathrm{c}$ & - & - & - & - & - & - & - & - \\
\hline FJ- 7,c & 0 & 100 & 0 & 0 & 0 & 0 & 0 & 0 \\
\hline FJ- $6, c$ & - & - & - & - & - & - & - & - \\
\hline FJ- 5,c & 40 & 60 & 0 & 0 & 0 & 0 & 0 & 0 \\
\hline FJ- 4,c & 5 & 84 & 0 & 0 & 0 & 5 & 5 & 11 \\
\hline FJ- 3,c & 42 & 50 & 0 & 0 & 0 & 0 & 8 & 8 \\
\hline FJ- 2,c & 68 & 32 & 0 & 0 & 0 & 0 & 0 & 0 \\
\hline FJ- 1,c & - & - & - & - & - & - & - & - \\
\hline
\end{tabular}

Acritarch groups

Ratio: (Polygonomorphitae + Netromorphitae)/Acanthomorphitae

\begin{tabular}{lc}
$\begin{array}{l}\text { Sample } \\
\text { no. }\end{array}$ & $\begin{array}{c}\text { Ratio: } \\
(\mathrm{P}+\mathrm{N}) / \mathrm{A}\end{array}$ \\
\hline FJ-16,c & 0.04 \\
FJ-15,c & 0.16 \\
FJ-14,c & - \\
FJ-13,c & - \\
FJ-12,c & 0.11 \\
FJ-11,c & 0.05 \\
FJ-10,c & - \\
FJ- 9,c & 0.02 \\
FJ- 8,c & - \\
FJ- 7,c & 0.00 \\
FJ- 6,c & - \\
FJ- 5,c & 0.00 \\
FJ- 4,c & 0.00 \\
FJ- 3,c & 0.09 \\
FJ- 2,c & 0.00 \\
FJ- 1,c & - \\
\hline
\end{tabular}


Mean values of the kerogen categories for each lithostratigraphical unit.

\begin{tabular}{|c|c|c|c|c|c|c|c|c|c|c|c|c|}
\hline & \multicolumn{2}{|c|}{ Fj. F. } & \multicolumn{2}{|c|}{ Ga. F. } & \multicolumn{2}{|c|}{ F-Ia M. } & \multicolumn{2}{|c|}{ F-Ib M. } & \multicolumn{2}{|c|}{ F-III M. } & \multicolumn{2}{|c|}{ F-IV M. } \\
\hline & mean & $\mathrm{n}$ & mean & $\mathrm{n}$ & mean & $\mathrm{n}$ & mean & $\mathrm{n}$ & mean & $\mathrm{n}$ & mean & n \\
\hline T.O.C. & 1.0 & 13 & 0.9 & 3 & 0.8 & 8 & 0.8 & 2 & 1.4 & 2 & 1.5 & 1 \\
\hline$\%$ palynomorphs & 21 & 13 & 7 & 3 & 15 & 8 & 23 & 2 & 43 & 2 & 23 & 1 \\
\hline$\%$ brown wood & 62 & 13 & 73 & 3 & 73 & 8 & 55 & 2 & 32 & 2 & 56 & 1 \\
\hline$\%$ black wood & 12 & 13 & 19 & 3 & 11 & 8 & 20 & 2 & 6 & 2 & 13 & 1 \\
\hline$\%$ cuticle & 0 & 13 & 0 & 3 & 0 & 8 & 0 & 2 & 0 & 2 & 1 & 1 \\
\hline$\%$ A.O.M. & 5 & 13 & 1 & 3 & 2 & 8 & 1 & 2 & 19 & 2 & 7 & 1 \\
\hline \multirow{2}{*}{$\begin{array}{l}\text { PhytOC } \\
\text { AmexOC }\end{array}$} & 0.68 & 13 & 0.85 & 3 & 0.71 & 8 & 0.58 & 2 & 0.54 & 2 & 1.03 & 1 \\
\hline & 0.06 & 13 & 0.01 & 3 & 0.02 & 8 & 0.01 & 2 & 0.27 & 2 & 0.11 & 1 \\
\hline$\%$ marine palynom. & 13 & 8 & 15 & 2 & 9 & 5 & 25 & 1 & 24 & 1 & 11 & 1 \\
\hline$\%$ spores & 32 & 8 & 35 & 2 & 41 & 5 & 23 & 1 & 8 & 1 & 20 & 1 \\
\hline$\%$ saccate pollen & 20 & 8 & 8 & 2 & 19 & 5 & 34 & 1 & 17 & 1 & 14 & 1 \\
\hline$\%$ non-sac. pollen & 48 & 8 & 58 & 2 & 40 & 5 & 42 & 1 & 75 & 1 & 66 & 1 \\
\hline sac. pollen/spores & 0.52 & 8 & 0.22 & 2 & 0.55 & 5 & 1.47 & 1 & 2.09 & 1 & 0.71 & 1 \\
\hline$\%$ dinofl. cysts & 11 & 8 & 55 & 2 & 9 & 5 & 20 & 1 & 8 & 1 & 13 & 1 \\
\hline$\%$ acritarchs & 86 & 8 & 41 & 2 & 89 & 5 & 80 & 1 & 89 & 1 & 75 & 1 \\
\hline$\%$ Tasmanaceae & 1 & 8 & 0 & 2 & 0 & 5 & 0 & 1 & 0 & 1 & 9 & 1 \\
\hline$\%$ Pterospermel. & 0 & 8 & 0 & 2 & 0 & 5 & 0 & 1 & 2 & 1 & 0 & 1 \\
\hline$\%$ Cymatiosph. & 0 & 8 & 0 & 2 & 0 & 5 & 0 & 1 & 3 & 1 & 0 & 1 \\
\hline$\%$ foram.testl. & 1 & 8 & 0 & 2 & 1 & 5 & 0 & 1 & 0 & 1 & 0 & 1 \\
\hline$\%$ limnic algae & 1 & 8 & 4 & 2 & 1 & 5 & 0 & 1 & 1 & 1 & 3 & 1 \\
\hline$(\mathrm{P}+\mathrm{N}) / \mathrm{A}$ & 0.05 & 8 & 0.05 & 2 & 0.01 & 5 & 0.11 & 1 & 0.16 & 1 & 0.04 & 1 \\
\hline
\end{tabular}




\section{Appendix B \\ The Frederikshavn-2 borehole}

Sample lithology

\begin{tabular}{|c|c|c|c|c|c|}
\hline $\begin{array}{l}\text { Lithostrat. } \\
\text { units }\end{array}$ & $\begin{array}{l}\text { Sample } \\
\text { no. }\end{array}$ & $\begin{array}{l}\text { Depth } \\
\text { (m.b.r.t.) }\end{array}$ & $\begin{array}{l}\text { Sample } \\
\text { lithology }\end{array}$ & & T.O.C. \\
\hline & Frh-22,c & 782 & si.cl.st. & $\psi \theta \xi$ & 1.0 \\
\hline \multirow[t]{5}{*}{ F-III Mb. } & Frh-21,c & 783 & cl.si.st. & $\psi \theta$ & 0.9 \\
\hline & Frh-20,c & 784 & cl.si.st. & $\psi \theta$ & 0.8 \\
\hline & Frh-19,c & 785 & si.cl.st. & $\psi \theta$ & 0.9 \\
\hline & Frh-18,c & 787 & si.cl.st. & $\psi \theta$ & 0.8 \\
\hline & Frh-17,c & 787 & clayst. & $\psi$ & 0.7 \\
\hline \multirow[t]{6}{*}{ F-II Mb. } & Frh-16,c & 788 & cl.si.st. & $\theta \xi$ & 0.7 \\
\hline & Frh-15,c & 789 & cl.sa.st. & & 0.8 \\
\hline & Frh-14,c & 851 & siltst. & $\psi \theta \xi$ & 1.0 \\
\hline & Frh-13,c & 854 & sa.cl.st. & $\theta$ & 0.9 \\
\hline & Frh-12,c & 880 & si.cl.st. & & 0.4 \\
\hline & Frh-11,c & 881 & si.cl.st. & & 1.2 \\
\hline \multirow[t]{6}{*}{ F-I Mb. } & Frh-10,c & 883 & si.cl.st. & & 0.4 \\
\hline & Frh- $9, \mathrm{c}$ & 884 & si.cl.st. & & 1.1 \\
\hline & Frh- 8,c & 885 & cl.si.st. & & 0.8 \\
\hline & Frh- 7,c & 886 & clayst. & & 1.0 \\
\hline & Frh- 6,c & 886 & sandst. & $\psi$ & 0.9 \\
\hline & Frh- 5,c & 887 & siltst. & $\psi$ & 1.5 \\
\hline Gassum & Frh- $4, \mathrm{c}$ & 889 & cl.si.st. & & 4.2 \\
\hline \multirow[t]{3}{*}{$\mathrm{Fm}$} & Frh- 3,c & 890 & cl.si.st. & & 2.3 \\
\hline & Frh- 2,c & 892 & cl.si.st. & & 1.0 \\
\hline & Frh- 1,c & 930 & clayst. & a & 4.7 \\
\hline
\end{tabular}

$\psi:$ plant remains

口: coal pieces

$\theta$ : shell remains

$\xi$ : burrows

clayst.: claystone

si.cl.st.: silt-streaked claystone

sa.cl.st.: sand-streaked claystone

siltst.: siltstone

cl.si.st.: clay-streaked siltstone

sandst.: sandstone

cl.sa.st.: clay-streaked sandstone
Kerogen categories

Relative abundances

\begin{tabular}{|c|c|c|c|c|c|c|}
\hline $\begin{array}{l}\text { Sample } \\
\text { no. }\end{array}$ & $\begin{array}{l}\text { Paly- } \\
\text { nom. } \\
\%\end{array}$ & $\begin{array}{c}\text { Br. } \\
\text { wood } \\
\%\end{array}$ & $\begin{array}{c}\text { Bl. } \\
\text { wood } \\
\%\end{array}$ & $\begin{array}{c}\text { Cuticle } \\
\%\end{array}$ & A.O.M. & $\begin{array}{c}\text { Total } \\
\%\end{array}$ \\
\hline Frh-22,c & 23 & 71 & 3 & 0 & 2 & 100 \\
\hline Frh-21,c & 15 & 81 & 2 & 1 & 1 & 100 \\
\hline Frh-20,c & 19 & 78 & 1 & 1 & 1 & 100 \\
\hline Frh-19,c & 17 & 77 & 2 & 0 & 4 & 100 \\
\hline Frh-18,c & 19 & 76 & 2 & 1 & 3 & 100 \\
\hline Frh-17,c & 26 & 70 & 1 & 1 & 2 & 100 \\
\hline Frh-16,c & 18 & 77 & 3 & 1 & 1 & 100 \\
\hline Frh-15,c & 11 & 86 & 2 & 0 & 1 & 100 \\
\hline Frh-14,c & 22 & 68 & 7 & 0 & 3 & 100 \\
\hline Frh-13,c & 15 & 78 & 4 & 0 & 3 & 100 \\
\hline Frh-12,c & 18 & 77 & 2 & 0 & 3 & 100 \\
\hline Frh-11,c & 21 & 66 & 11 & 0 & 2 & 100 \\
\hline Frh-10,c & 18 & 75 & 5 & 0 & 2 & 100 \\
\hline Frh- 9,c & 22 & 70 & 6 & 0 & 2 & 100 \\
\hline Frh- 8,c & 30 & 64 & 6 & 0 & 1 & 100 \\
\hline Frh- 7,c & 23 & 72 & 4 & 0 & 1 & 100 \\
\hline Frh- $6, \mathrm{c}$ & 4 & 92 & 3 & 0 & 0 & 100 \\
\hline Frh- 5,c & 8 & 86 & 5 & 1 & 0 & 100 \\
\hline Frh- 4,c & 22 & 45 & 31 & 0 & 2 & 100 \\
\hline Frh- 3,c & 5 & 87 & 8 & 0 & 1 & 100 \\
\hline Frh- 2,c & 17 & 71 & 11 & 0 & 1 & 100 \\
\hline Frh- $1, \mathrm{c}$ & 6 & 93 & 1 & 0 & 0 & 100 \\
\hline
\end{tabular}


Brown wood, size groups, relative abundances $100 \%=$ total of brown wood

\begin{tabular}{|c|c|c|c|c|}
\hline $\begin{array}{l}\text { Sample } \\
\text { no. }\end{array}$ & $\begin{array}{c}<20 \\
\text { microns } \\
\%\end{array}$ & $\begin{array}{c}20-80 \\
\text { microns } \\
\%\end{array}$ & $\begin{array}{c}>80 \\
\text { microns } \\
\%\end{array}$ & $\begin{array}{c}\text { Total } \\
\%\end{array}$ \\
\hline Frh-22,c & 32 & 67 & 1 & 100 \\
\hline Frh-21,c & 40 & 59 & 0 & 100 \\
\hline Frh-20,c & 38 & 61 & 0 & 100 \\
\hline Frh-19,c & 32 & 67 & 2 & 100 \\
\hline Frh-18,c & 30 & 69 & 1 & 100 \\
\hline Frh-17,c & 35 & 64 & 1 & 100 \\
\hline Frh-16,c & 60 & 40 & 0 & 100 \\
\hline Frh-15,c & 56 & 44 & 0 & 100 \\
\hline Frh-14,c & 38 & 61 & 1 & 100 \\
\hline Frh-13,c & 29 & 70 & 1 & 100 \\
\hline Frh-12,c & 33 & 66 & 1 & 100 \\
\hline Frh-11,c & 23 & 75 & 2 & 100 \\
\hline Frh-10,c & 31 & 68 & 1 & 100 \\
\hline Frh- $9, \mathrm{c}$ & 40 & 60 & 0 & 100 \\
\hline Frh- 8,c & 41 & 58 & 1 & 100 \\
\hline Frh- $7, \mathrm{c}$ & 42 & 56 & 2 & 100 \\
\hline Frh- 6,c & 55 & 44 & 1 & 100 \\
\hline Frh- 5,c & 30 & 70 & 0 & 100 \\
\hline Frh- 4,c & 24 & 74 & 2 & 100 \\
\hline Frh- 3,c & 51 & 49 & 0 & 100 \\
\hline Frh- 2,c & 37 & 62 & 1 & 100 \\
\hline Frh- $1, \mathrm{c}$ & 49 & 50 & 1 & 100 \\
\hline
\end{tabular}

Black wood, size groups, relative abundances $100 \%=$ total of black wood

\begin{tabular}{lcccc}
\hline $\begin{array}{l}\text { Sample } \\
\text { no. }\end{array}$ & $\begin{array}{c}<0 \\
\text { microns }\end{array}$ & $\begin{array}{c}20-80 \\
\text { microns }\end{array}$ & $\begin{array}{c}>80 \\
\text { microns }\end{array}$ & Total
\end{tabular}

$\% \quad \% \quad \%$

Frh-22,c

Frh-21,c

Frh-20,c

Frh-19,c

Frh-18,c

Frh-17,c

Frh-16,c

Frh-15,c

Frh-14,c

Frh-13,c

Frh-12,c

Frh-11,c

Frh-10,c

Frh- 9,c

Frh- 8,c

Frh- 7,c

Frh- 6,c

Frh- 5,c

Frh- 4,c

Frh- 3,c

Frh- 2,c

Frh- 1,c

$\begin{array}{rrrl}50 & 44 & 6 & 100 \\ 50 & 40 & 10 & 100 \\ 67 & 33 & 0 & 100 \\ 69 & 23 & 8 & 100 \\ 67 & 33 & 0 & 100 \\ 50 & 38 & 13 & 100 \\ 44 & 56 & 0 & 100 \\ 38 & 54 & 8 & 100 \\ 17 & 83 & 0 & 100 \\ 10 & 85 & 5 & 100 \\ 15 & 85 & 0 & 100 \\ 36 & 64 & 0 & 100 \\ 42 & 58 & 0 & 100 \\ 34 & 63 & 3 & 100 \\ 48 & 52 & 0 & 100 \\ 45 & 50 & 5 & 100 \\ 47 & 47 & 6 & 100 \\ 19 & 78 & 4 & 100 \\ 49 & 50 & 1 & 100 \\ 34 & 66 & 0 & 100 \\ 32 & 66 & 2 & 100 \\ 0 & 86 & 14 & 100 \\ & & & \end{array}$

Kerogen categories

Absolute abundance

\begin{tabular}{|c|c|c|c|c|c|c|c|c|c|c|c|c|}
\hline $\begin{array}{l}\text { Sample } \\
\text { no. }\end{array}$ & $\begin{array}{l}\text { Palyno- } \\
\text { morphs }\end{array}$ & $\begin{array}{l}\text { Brown } \\
\text { wood }\end{array}$ & $\begin{array}{c}<20 \\
\text { microns }\end{array}$ & $\begin{array}{c}20-80 \\
\text { microns }\end{array}$ & $\begin{array}{c}>80 \\
\text { microns }\end{array}$ & $\begin{array}{l}\text { Black } \\
\text { wood }\end{array}$ & $\begin{array}{c}<20 \\
\text { microns }\end{array}$ & $\begin{array}{c}20-80 \\
\text { microns }\end{array}$ & $\begin{array}{c}>80 \\
\text { microns }\end{array}$ & Cuticle & A.O.M & $\mathbf{n}$ \\
\hline Frh-22,c & 140 & 430 & 139 & 288 & 3 & 18 & 9 & 8 & 1 & 1 & 15 & 604 \\
\hline Frh-21,c & 84 & 448 & 181 & 266 & 1 & 10 & 5 & 4 & 1 & 4 & 6 & 552 \\
\hline Frh-20,c & 120 & 501 & 191 & 308 & 2 & 9 & 6 & 3 & 0 & 4 & 5 & 639 \\
\hline Frh-19,c & 103 & 463 & 147 & 308 & 8 & 13 & 9 & 3 & 1 & 2 & 23 & 604 \\
\hline Frh-17,c & 140 & 375 & 133 & 239 & 3 & 8 & 4 & 3 & 1 & 3 & 11 & 537 \\
\hline Frh-16,c & 103 & 433 & 259 & 172 & 2 & 16 & 7 & 9 & 0 & 3 & 4 & 559 \\
\hline Frh-15,c & 59 & 466 & 259 & 206 & 1 & 13 & 5 & 7 & 1 & 2 & 5 & 545 \\
\hline Frh-14,c & 119 & 362 & 137 & 221 & 4 & 35 & 6 & 29 & 0 & 2 & 14 & 532 \\
\hline Frh-13,c & 83 & 424 & 124 & 297 & 3 & 20 & 2 & 17 & 1 & 2 & 16 & 545 \\
\hline Frh-12,c & 101 & 432 & 143 & 284 & 5 & 13 & 2 & 11 & 0 & 0 & 17 & 563 \\
\hline Frh-11,c & 120 & 382 & 87 & 288 & 7 & 67 & 24 & 43 & 0 & 0 & 14 & 583 \\
\hline Frh- $9, \mathrm{c}$ & 129 & 401 & 159 & 240 & 2 & 32 & 11 & 20 & 1 & 0 & 12 & 574 \\
\hline Frh- 8,c & 164 & 346 & 142 & 200 & 4 & 31 & 15 & 16 & 0 & 0 & 3 & 544 \\
\hline Frh- 7,c & 126 & 392 & 166 & 220 & 6 & 20 & 9 & 10 & 1 & 1 & 4 & 543 \\
\hline Frh- 6,c & 27 & 588 & 323 & 260 & 5 & 17 & 8 & 8 & 1 & 2 & 3 & 637 \\
\hline Frh- 5,c & 45 & 467 & 138 & 327 & 2 & 27 & 5 & 21 & 1 & 3 & 0 & 542 \\
\hline Frh- $4, \mathrm{c}$ & 128 & 258 & 62 & 192 & 4 & 174 & 86 & 87 & 1 & 0 & 9 & 569 \\
\hline Frh- 3,c & 27 & 516 & 262 & 252 & 2 & 47 & 16 & 31 & 0 & 1 & 4 & 595 \\
\hline Frh- $2, \mathrm{c}$ & 94 & 393 & 147 & 244 & 2 & 62 & 20 & 41 & 1 & 0 & 3 & 552 \\
\hline Frh- 1,c & 33 & 537 & 261 & 270 & 6 & 7 & 0 & 6 & 1 & 0 & 0 & 577 \\
\hline
\end{tabular}




\begin{tabular}{lccc}
\hline $\begin{array}{l}\text { Sample } \\
\text { no. }\end{array}$ & PhytOC & AmexOC & $\begin{array}{c}\text { Marine } \\
\text { palynom. \% }\end{array}$ \\
\hline Frh-22,c & 0.76 & 0.03 & 20 \\
Frh-21,c & 0.75 & 0.01 & 29 \\
Frh-20,c & 0.63 & 0.01 & - \\
Frh-19,c & 0.70 & 0.03 & 15 \\
Frh-18,c & 0.60 & 0.02 & - \\
Frh-17,c & 0.50 & 0.01 & 2 \\
Frh-16,c & 0.60 & 0.01 & - \\
Frh-15,c & 0.74 & 0.01 & 16 \\
Frh-14,c & 0.77 & 0.03 & 13 \\
Frh-13,c & 0.77 & 0.03 & 7 \\
Frh-12,c & 0.35 & 0.01 & 5 \\
Frh-11,c & 0.90 & 0.03 & - \\
Frh-10,c & 0.30 & 0.01 & - \\
Frh- 9,c & 0.86 & 0.02 & 16 \\
Frh- 8,c & 0.52 & 0.00 & 8 \\
Frh- 7,c & 0.72 & 0.01 & 5 \\
Frh- 6,c & 0.87 & 0.00 & 5 \\
Frh- 5,c & 1.40 & 0.00 & - \\
Frh- 4,c & 3.16 & 0.07 & 9 \\
Frh- 3,c & 2.18 & 0.02 & - \\
Frh- 2,c & 0.78 & 0.01 & 12 \\
Frh- 1,c & 4.42 & 0.00 & 15 \\
\hline & & & \\
\hline
\end{tabular}

\begin{tabular}{|c|c|c|c|c|c|}
\hline $\begin{array}{l}\text { Sample } \\
\text { no. }\end{array}$ & Spores & $\begin{array}{l}\text { Saccate } \\
\text { pollen } \\
\%\end{array}$ & $\begin{array}{c}\text { Non- } \\
\text { pollen } \\
\text { pollen } \\
\%\end{array}$ & $\begin{array}{c}\text { Total } \\
\text { saccate } \\
\text { pollen } \\
\%\end{array}$ & $\begin{array}{l}\text { Ratio: } \\
\text { pollen/ } \\
\text { spores }\end{array}$ \\
\hline Frh-22,c & 38 & 11 & 51 & 100 & 0.28 \\
\hline Frh-21,c & 40 & 12 & 48 & 100 & 0.31 \\
\hline Frh-20,c & - & - & - & - & - \\
\hline Frh-19,c & 34 & 15 & 50 & 100 & 0.45 \\
\hline Frh-18,c & - & - & - & - & - \\
\hline Frh-17,c & 34 & 13 & 53 & 100 & 0.37 \\
\hline Frh-16,c & - & - & - & - & - \\
\hline Frh-15,c & 30 & 21 & 49 & 100 & 0.72 \\
\hline Frh-14,c & 36 & 15 & 49 & 100 & 0.41 \\
\hline Frh-13,c & 38 & 20 & 42 & 100 & 0.53 \\
\hline Frh-12,c & 45 & 18 & 37 & 100 & 0.40 \\
\hline Frh-11,c & - & - & - & - & - \\
\hline Frh-10,c & - & - & - & - & - \\
\hline Frh- 9,c & 28 & 16 & 55 & 100 & 0.57 \\
\hline Frh- 8,c & 41 & 17 & 42 & 100 & 0.42 \\
\hline Frh- 7,c & 51 & 13 & 36 & 100 & 0.25 \\
\hline Frh- 6,c & 45 & 16 & 39 & 100 & 0.36 \\
\hline Frh- 5,c & - & - & - & - & - \\
\hline Frh- 4,c & 43 & 14 & 43 & 100 & 0.33 \\
\hline Frh- 3,c & - & - & - & - & - \\
\hline Frh- 2,c & 46 & 20 & 34 & 100 & 0.44 \\
\hline Frh- $1, \mathrm{c}$ & 43 & 13 & 44 & 100 & 0.29 \\
\hline
\end{tabular}

PhytOC $=(\%$ brown wood $+\%$ black wood $+\%$ cuticle $) \times$ T.O.C AmexOC $=\%$ Amorphous Organic Matter (A.O.M.) $\times$ T.O.C.

$\%$ marine palynomorphs: $100 \%=$ total palynomorphs

Aquatic palynomorphs

Relative abundances

\begin{tabular}{|c|c|c|c|c|c|c|c|}
\hline $\begin{array}{l}\text { Sample } \\
\text { no. }\end{array}$ & $\begin{array}{c}\text { Dinofl. } \\
\text { cysts } \\
\%\end{array}$ & $\begin{array}{c}\text { Acri- } \\
\text { tarchs } \\
\%\end{array}$ & $\begin{array}{c}\text { Tasma- } \\
\text { naceae } \\
\% \\
\%\end{array}$ & $\begin{array}{c}\text { Cymat. } \\
\text { sphera. } \\
\quad \%\end{array}$ & $\begin{array}{c}\text { Foram. } \\
\text { testl. } \\
\quad \%\end{array}$ & $\begin{array}{c}\text { Limnic } \\
\text { algae } \\
\quad \%\end{array}$ & $\begin{array}{c}\text { Total } \\
\text { aquat. } \\
\text { palyn. } \\
\%\end{array}$ \\
\hline Frh-22,c & 57 & 28 & 0 & 0 & 0 & 15 & 100 \\
\hline Frh-21,c & 76 & 13 & 1 & 0 & 0 & 10 & 100 \\
\hline Frh-20,c & - & - & - & - & - & - & - \\
\hline Frh-19,c & 59 & 16 & 0 & 0 & 0 & 25 & 100 \\
\hline Frh-18,c & - & - & - & - & - & - & - \\
\hline Frh-17,c & 23 & 15 & 0 & 0 & 0 & 62 & 100 \\
\hline Frh-16,c & - & - & - & - & - & - & - \\
\hline Frh-15,c & 12 & 82 & 0 & 2 & 0 & 4 & 100 \\
\hline Frh-14,c & 0 & 98 & 0 & 0 & 0 & 2 & 100 \\
\hline Frh-13,c & 4 & 91 & 0 & 0 & 4 & 0 & 100 \\
\hline Frh-12,c & 40 & 53 & 0 & 0 & 0 & 7 & 100 \\
\hline Frh-11,c & - & - & - & - & - & - & - \\
\hline Frh-10,c & - & - & - & - & - & - & - \\
\hline Frh- $9, \mathrm{c}$ & 2 & 97 & 0 & 0 & 0 & 2 & 100 \\
\hline Frh- 8,c & 0 & 100 & 0 & 0 & 0 & 0 & 100 \\
\hline Frh- 7,c & 7 & 93 & 0 & 0 & 0 & 0 & 100 \\
\hline Frh- 6,c & 0 & 100 & 0 & 0 & 0 & 0 & 100 \\
\hline Frh- 5,c & - & - & - & - & - & - & - \\
\hline Frh- $4, \mathrm{c}$ & 3 & 84 & 3 & 0 & 0 & 9 & 100 \\
\hline Frh- 3,c & - & - & - & - & - & - & - \\
\hline Frh- 2,c & 0 & 100 & 0 & 0 & 0 & 0 & 100 \\
\hline Frh- $1, \mathrm{c}$ & 0 & 98 & 0 & 0 & 0 & 2 & 100 \\
\hline
\end{tabular}




\begin{tabular}{lc}
\hline $\begin{array}{l}\text { Sample } \\
\text { no. }\end{array}$ & $\begin{array}{c}\text { Ratio: } \\
(\mathrm{P}+\mathrm{N}) / \mathrm{A}\end{array}$ \\
\hline Frh-22,c & 0.10 \\
Frh-21,c & 0.13 \\
Frh-20,c & - \\
Frh-19,c & 0.25 \\
Frh-18,c & - \\
Frh-17,c & 1.00 \\
Frh-16,c & - \\
Frh-15,c & 0.12 \\
Frh-14,c & 0.19 \\
Frh-13,c & 0.40 \\
Frh-12,c & 0.14 \\
Frh-11,c & - \\
Frh-10,c & - \\
Frh- 9,c & 0.19 \\
Frh- 8,c & 0.47 \\
Frh- 7,c & 0.17 \\
Frh- 6,c & 0.27 \\
Frh- 5,c & - \\
Frh- 4,c & 0.04 \\
Frh- 3,c & - \\
Frh- 2,c & 0.05 \\
Frh- 1,c & 0.02 \\
\hline
\end{tabular}

Mean values of the kerogen categories for each lithostratigraphical unit.

\begin{tabular}{|c|c|c|c|c|c|c|c|c|c|c|}
\hline & \multicolumn{2}{|c|}{ Fj. F. } & \multicolumn{2}{|c|}{ Ga. F. } & \multicolumn{2}{|c|}{ F-I M. } & \multicolumn{2}{|c|}{ F-II M. } & \multicolumn{2}{|c|}{ F-III M. } \\
\hline & mean & $\mathrm{n}$ & mean & $\mathbf{n}$ & mean & $\mathbf{n}$ & mean & $\mathrm{n}$ & mean & $\mathbf{n}$ \\
\hline T.O.C. & 0.8 & 15 & 2.2 & 7 & 0.8 & 5 & 0.8 & 6 & 0.9 & 4 \\
\hline$\%$ palynomorphs & 20 & 15 & 12 & 7 & 22 & 5 & 19 & 6 & 19 & 4 \\
\hline$\%$ brown wood & 74 & 15 & 78 & 7 & 70 & 5 & 6 & 6 & 77 & 4 \\
\hline$\%$ black wood & 4 & 15 & 9 & 7 & 6 & 5 & 3 & 6 & 2 & 4 \\
\hline$\%$ cuticle & 0 & 15 & 0 & 7 & 0 & 5 & 1 & 6 & 0 & 4 \\
\hline$\%$ A.O.M. & 2 & 15 & 1 & 7 & 2 & 5 & 2 & 6 & 2 & 4 \\
\hline PhytOC & 0.65 & 15 & 1.93 & 7 & 0.59 & 5 & 0.66 & 6 & 0.71 & 4 \\
\hline AmexOC & 0.02 & 15 & 0.02 & 7 & 0.01 & 5 & 0.02 & 6 & 0.02 & 4 \\
\hline$\%$ marine palynom. & 13 & 10 & 9 & 5 & 10 & 3 & 9 & 4 & 21 & 3 \\
\hline$\%$ spores & 36 & 10 & 46 & 5 & 38 & 3 & 34 & 4 & 37 & 3 \\
\hline$\%$ saccate pollen & 16 & 10 & 15 & 5 & 17 & 3 & 17 & 4 & 13 & 3 \\
\hline$\%$ non-sac. pollen & 48 & 10 & 39 & 5 & 45 & 3 & 48 & 4 & 50 & 3 \\
\hline sac. pollen/spores & 0.45 & 10 & 0.33 & 5 & 0.46 & 3 & 0.51 & 4 & 0.35 & 3 \\
\hline$\%$ dinofl. cysts & 27 & 10 & 2 & 5 & 14 & 3 & 10 & 4 & 64 & 3 \\
\hline$\%$ acritarchs & 60 & 10 & 95 & 5 & 83 & 3 & 72 & 4 & 19 & 3 \\
\hline$\%$ Tasmanaceae & 0 & 10 & 1 & 5 & 0 & 3 & 0 & 4 & 0 & 3 \\
\hline$\%$ Pterospermel. & 0 & 10 & 0 & 5 & 0 & 3 & 0 & 4 & 0 & 3 \\
\hline$\%$ Cymatiosph. & 0 & 10 & 0 & 5 & 0 & 3 & 1 & 4 & 0 & 3 \\
\hline \% foram.testl. & 0 & 10 & 0 & 5 & 0 & 3 & 1 & 4 & 0 & 3 \\
\hline$\%$ limnic algae & 13 & 10 & 2 & 5 & 3 & 3 & 17 & 4 & 17 & 3 \\
\hline$(P+N) / A$ & 0.30 & 10 & 0.11 & 5 & 0.27 & 3 & 0.42 & 4 & 0.16 & 3 \\
\hline
\end{tabular}




\section{Appendix C \\ The Stenlille-2 borehole}

\begin{tabular}{|c|c|c|c|c|c|}
\hline $\begin{array}{l}\text { Lithostrat. } \\
\text { units }\end{array}$ & $\begin{array}{c}\text { Sample } \\
\text { no. }\end{array}$ & $\begin{array}{c}\text { Depth } \\
\text { (m.b.r.t.) }\end{array}$ & $\begin{array}{c}\text { Sample } \\
\text { lithology }\end{array}$ & & T.O.C. \\
\hline F-IV Mb. & St-16,w & 1228 & si.cl.st. & & 0.4 \\
\hline \multirow[t]{2}{*}{ F-III Mb. } & St-15,w & 1234 & clayst. & & 1.9 \\
\hline & St-14,w & 1240 & sa.cl.st. & & 0.8 \\
\hline \multirow[t]{12}{*}{ F-II Mb. } & St-13,w & 1246 & sa.cl.st. & & 0.8 \\
\hline & St-12,w & 1252 & cl.si.st. & & 0.5 \\
\hline & St- $11, w$ & 1258 & si.cl.st. & & 0.9 \\
\hline & St-10,w & 1380 & sa.cl.st. & & 0.8 \\
\hline & St- $9, w$ & 1390 & clayst. & & 0.8 \\
\hline & St- $8, w$ & 1392 & clayst. & & 1.0 \\
\hline & St- $7, w$ & 1401 & cl.sa.st. & & 0.4 \\
\hline & St- $6, w$ & 1413 & si.cl.st. & & 0.9 \\
\hline & St- $5, w$ & 1424 & sa.cl.st. & & 1.2 \\
\hline & St- $4, w$ & 1441 & clayst. & & 0.9 \\
\hline & St- 3,w & 1452 & cl.sa.st. & & 0.5 \\
\hline & St- $2, w$ & 1460 & clayst. & & 1.1 \\
\hline \multirow[t]{10}{*}{ F-Ia Mb. } & St- $1, w$ & 1472 & clayst. & & 0.7 \\
\hline & St-11,c & 1476 & si.cl.st. & & 0.8 \\
\hline & St-10,c & 1477 & clayst. & & 0.9 \\
\hline & St- $9, \mathrm{c}$ & 1478 & clayst. & & 1.1 \\
\hline & St- $8, \mathrm{c}$ & 1491 & clayst. & & 1.0 \\
\hline & St- $7, \mathrm{c}$ & 1493 & cl.sa.st. & $\xi$ & 1.4 \\
\hline & St- $6, \mathrm{c}$ & 1494 & sa.cl.st. & & 1.5 \\
\hline & St- $5, \mathrm{c}$ & 1496 & sa.cl.st. & & 1.7 \\
\hline & St- $4, \mathrm{c}$ & 1503 & sandst. & & 0.4 \\
\hline & St- $3, \mathrm{c}$ & 1510 & clayst. & & 1.5 \\
\hline Gassum & St- $2, c$ & 1512 & sa.cl.st. & & 2.7 \\
\hline $\mathrm{Fm}$ & St- $1, \mathrm{c}$ & 1513 & cl.sa.st. & $\boldsymbol{\square}$ & 2.6 \\
\hline
\end{tabular}

Kerogen categories

Relative abundances

\begin{tabular}{lrrrrrr}
\hline $\begin{array}{l}\text { Sample } \\
\text { no. }\end{array}$ & $\begin{array}{c}\text { Paly- } \\
\text { nom. } \\
\%\end{array}$ & $\begin{array}{c}\text { Br. } \\
\text { wood } \\
\%\end{array}$ & $\begin{array}{c}\text { Bl. } \\
\text { wood } \\
\%\end{array}$ & $\begin{array}{c}\text { Cuticle } \\
\%\end{array}$ & $\begin{array}{c}\text { A.O.M. } \\
\text { \% }\end{array}$ & Total \\
\hline St-16,w & 16 & 63 & 1 & 2 & 18 & 100 \\
St-15,w & 22 & 1 & 0 & 0 & 76 & 100 \\
St-14,w & 45 & 42 & 9 & 0 & 3 & 100 \\
St-13,w & 39 & 36 & 8 & 0 & 17 & 100 \\
St-12,w & 30 & 64 & 5 & 0 & 1 & 100 \\
St-11,w & 41 & 50 & 6 & 0 & 2 & 100 \\
St-10,w & - & - & - & - & - & - \\
St- 9,w & 24 & 69 & 7 & 0 & 0 & 100 \\
St- 8,w & 14 & 78 & 6 & 0 & 3 & 100 \\
St- 7,w & 3 & 90 & 7 & 0 & 0 & 100 \\
St- 6,w & 13 & 77 & 5 & 0 & 4 & 100 \\
St- 5,w & 16 & 77 & 6 & 0 & 1 & 100 \\
St- 4,w & 17 & 78 & 4 & 0 & 1 & 100 \\
St- 3,w & 1 & 97 & 2 & 0 & 0 & 100 \\
St- 2,w & 10 & 81 & 3 & 0 & 6 & 100 \\
St- 1,w & 11 & 65 & 3 & 0 & 20 & 100 \\
St-11,c & 18 & 73 & 7 & 0 & 2 & 100 \\
St-10,c & 14 & 79 & 4 & 0 & 2 & 100 \\
St- 9,c & 17 & 66 & 6 & 0 & 12 & 100 \\
St- 8,c & 22 & 66 & 6 & 0 & 7 & 100 \\
St- 7,c & 17 & 75 & 6 & 0 & 2 & 100 \\
St- 6,c & 14 & 79 & 6 & 0 & 1 & 100 \\
St- 5,c & 7 & 88 & 6 & 0 & 0 & 100 \\
St- 4,c & 1 & 70 & 29 & 0 & 0 & 100 \\
St- 3,c & 20 & 69 & 11 & 0 & 0 & 100 \\
St- 2,c & 18 & 68 & 6 & 0 & 8 & 100 \\
St- 1,c & 4 & 80 & 17 & 0 & 0 & 100 \\
\hline & & & & & & \\
\hline
\end{tabular}

$\xi$. burrows

clayst.: claystone

si.cl.st.: silt-streaked claystone

sa.cl.st.: sand-streaked claystone

cl.si.st.: clay-streaked siltstone

sandst.: sandstone

cl.sa.st.: clay-streaked sandstone 
Brown wood, size groups, relative abundances $100 \%=$ total of brown wood

\begin{tabular}{|c|c|c|c|c|}
\hline $\begin{array}{l}\text { Sample } \\
\text { no. }\end{array}$ & $\begin{array}{c}<20 \\
\text { microns } \\
\%\end{array}$ & $\begin{array}{c}20-80 \\
\text { microns } \\
\%\end{array}$ & $\begin{array}{c}>80 \\
\text { microns } \\
\%\end{array}$ & $\begin{array}{c}\text { Total } \\
\%\end{array}$ \\
\hline St-16,w & 38 & 48 & 14 & 100 \\
\hline St-15,w & 25 & 75 & 0 & 100 \\
\hline St-14,w & 60 & 38 & 2 & 100 \\
\hline St-13,w & 58 & 40 & 2 & 100 \\
\hline St-12,w & 68 & 30 & 2 & 100 \\
\hline St -11 ,w & 76 & 22 & 2 & 100 \\
\hline St $-10, w$ & - & - & - & - \\
\hline St $-9, w$ & 78 & 22 & 0 & 100 \\
\hline St $-8, w$ & 78 & 22 & 0 & 100 \\
\hline St- 7,w & 90 & 10 & 0 & 100 \\
\hline St- 6,w & 70 & 29 & 1 & 100 \\
\hline St- $5, w$ & 78 & 21 & 1 & 100 \\
\hline St- $4, w$ & 72 & 26 & 1 & 100 \\
\hline St- 3,w & 80 & 20 & 0 & 100 \\
\hline St- 2,w & 77 & 23 & 1 & 100 \\
\hline St- 1,w & 72 & 27 & 1 & 100 \\
\hline St-11,c & 70 & 29 & 1 & 100 \\
\hline St-10,c & 79 & 21 & 0 & 100 \\
\hline St- $9, c$ & 76 & 23 & 1 & 100 \\
\hline St- 8,c & 79 & 21 & 0 & 100 \\
\hline St- 7,c & 71 & 27 & 2 & 100 \\
\hline St- 6,c & 68 & 30 & 2 & 100 \\
\hline St- 5,c & 76 & 24 & 0 & 100 \\
\hline St- 4,c & 76 & 23 & 0 & 100 \\
\hline St- 3,c & 62 & 37 & 1 & 100 \\
\hline St- 2,c & 64 & 35 & 1 & 100 \\
\hline St- 1,c & 73 & 26 & 1 & 100 \\
\hline
\end{tabular}

Kerogen categories

Absolute abundance

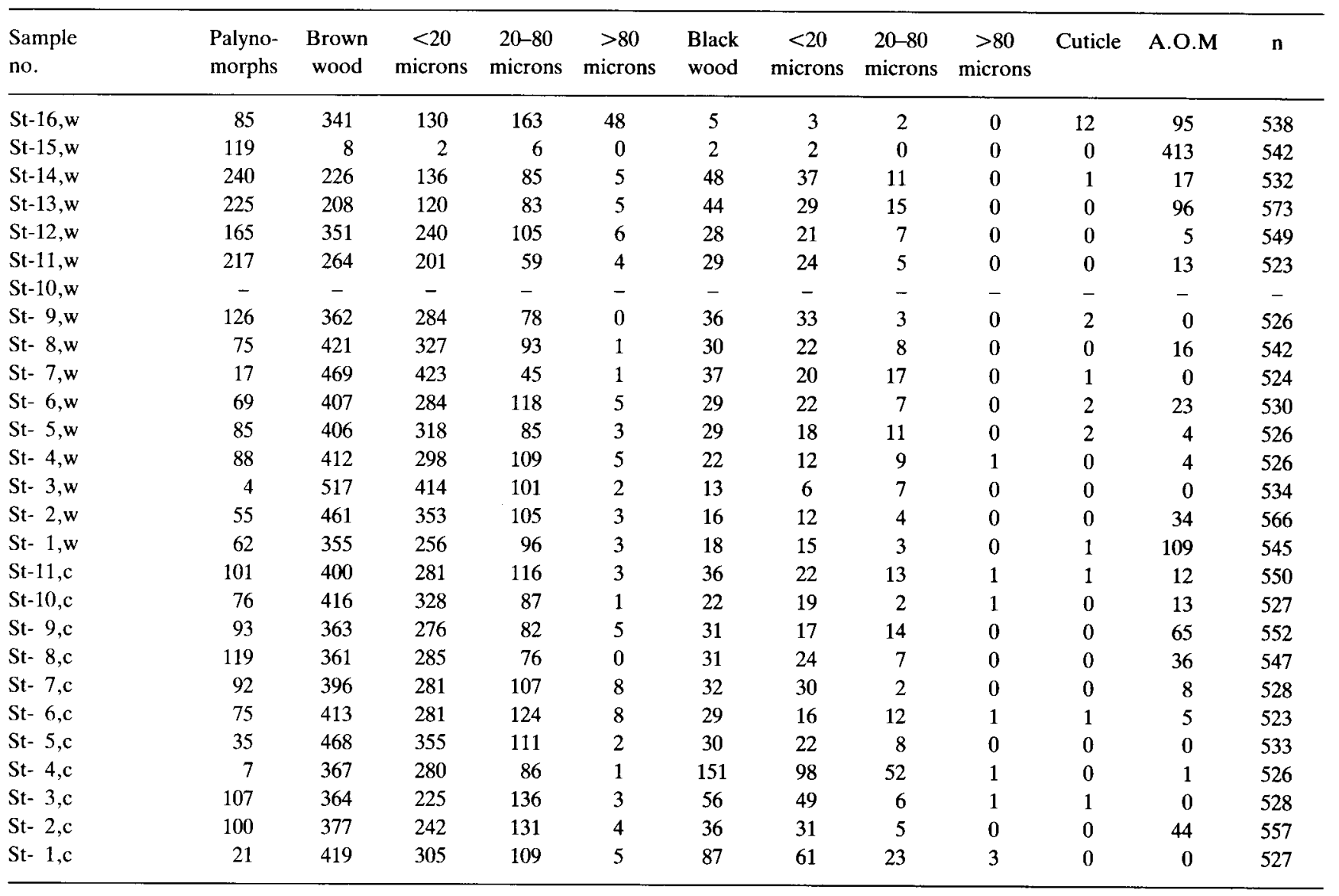

Black wood, size groups, relative abundances $100 \%=$ total of black wood

\begin{tabular}{|c|c|c|c|c|}
\hline $\begin{array}{l}\text { Sample } \\
\text { no. }\end{array}$ & $\begin{array}{c}<20 \\
\text { microns } \\
\%\end{array}$ & $\begin{array}{c}20-80 \\
\text { microns } \\
\%\end{array}$ & $\begin{array}{c}>80 \\
\text { microns } \\
\%\end{array}$ & $\begin{array}{c}\text { Total } \\
\%\end{array}$ \\
\hline St-16,w & 60 & 40 & 0 & 100 \\
\hline St-15,w & 100 & 0 & 0 & 100 \\
\hline St-14,w & 77 & 23 & 0 & 100 \\
\hline St $-13, w$ & 66 & 34 & 0 & 100 \\
\hline St-12,w & 75 & 25 & 0 & 100 \\
\hline St-11,w & 83 & 17 & 0 & 100 \\
\hline St-10,w & - & - & - & - \\
\hline St- $9, w$ & 92 & 8 & 0 & 100 \\
\hline St- $8, w$ & 73 & 27 & 0 & 100 \\
\hline St- $7, w$ & 54 & 46 & 0 & 100 \\
\hline St- $6, w$ & 76 & 24 & 0 & 100 \\
\hline St- $5, w$ & 62 & 38 & 0 & 100 \\
\hline St- $4, w$ & 55 & 41 & 5 & 100 \\
\hline St- 3,w & 46 & 54 & 0 & 100 \\
\hline St- $2, w$ & 75 & 25 & 0 & 100 \\
\hline St- $1, w$ & 83 & 17 & 0 & 100 \\
\hline St-11,c & 61 & 36 & 3 & 100 \\
\hline St-10,c & 86 & 9 & 5 & 100 \\
\hline St- $9, \mathrm{c}$ & 55 & 45 & 0 & 100 \\
\hline St- $8, c$ & 77 & 23 & 0 & 100 \\
\hline St- 7,c & 94 & 6 & 0 & 100 \\
\hline St- $6, c$ & 55 & 41 & 3 & 100 \\
\hline St- $5, \mathrm{c}$ & 73 & 27 & 0 & 100 \\
\hline St- 4,c & 65 & 34 & 1 & 100 \\
\hline St- 3,c & 88 & 11 & 2 & 100 \\
\hline St- 2,c & 86 & 14 & 0 & 100 \\
\hline St- $1, \mathrm{c}$ & 70 & 26 & 3 & 100 \\
\hline
\end{tabular}




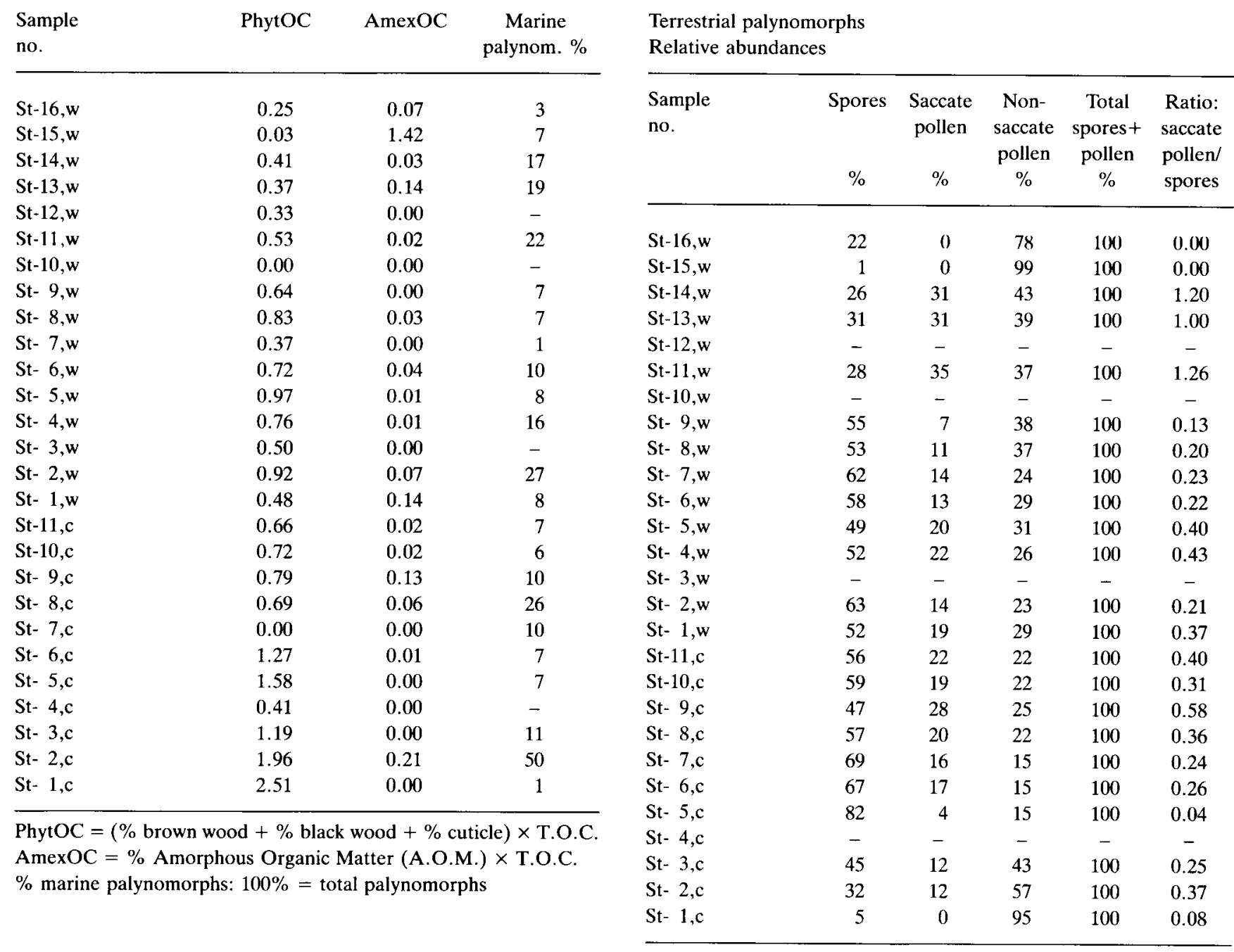


Aquatic palynomorphs

Relative abundances

\begin{tabular}{|c|c|c|c|c|c|c|c|}
\hline $\begin{array}{l}\text { Sample } \\
\text { no. }\end{array}$ & $\begin{array}{c}\text { Dinofl. } \\
\text { cysts } \\
\\
\%\end{array}$ & $\begin{array}{c}\text { Acri- } \\
\text { tarchs }\end{array}$ & $\begin{array}{c}\text { Tasma- } \\
\text { naceae } \\
\%\end{array}$ & $\begin{array}{l}\text { Ptero- } \\
\text { sperm. } \\
\text { \% }\end{array}$ & $\begin{array}{c}\text { Cymatio- } \\
\text { sphera. } \\
\%\end{array}$ & $\begin{array}{c}\text { Limnic } \\
\text { algae } \\
\%\end{array}$ & $\begin{array}{c}\text { Total } \\
\text { aquat. } \\
\text { palyno. } \\
\%\end{array}$ \\
\hline St-16,w & 0 & 100 & 0 & 0 & 0 & 0 & 100 \\
\hline St-15,w & 14 & 59 & 0 & 18 & 9 & 0 & 100 \\
\hline St-14,w & 3 & 87 & 0 & 2 & 2 & 6 & 100 \\
\hline St-13,w & 5 & 91 & 0 & 0 & 0 & 4 & 100 \\
\hline St-12,w & - & - & - & - & - & - & - \\
\hline St-11,w & 7 & 92 & 0 & 0 & 1 & 0 & 100 \\
\hline St-10,w & - & - & - & - & - & - & - \\
\hline St- $9, \mathrm{w}$ & 48 & 52 & 0 & 0 & 0 & 0 & 100 \\
\hline St- $8, w$ & 0 & 100 & 0 & 0 & 0 & 0 & 100 \\
\hline St- $7, w$ & 0 & 100 & 0 & 0 & 0 & 0 & 100 \\
\hline St- $6, w$ & 14 & 86 & 0 & 0 & 0 & 0 & 100 \\
\hline St- $5, \mathrm{w}$ & 13 & 83 & 0 & 0 & 0 & 4 & 100 \\
\hline St- $4, w$ & 16 & 84 & 0 & 0 & 0 & 0 & 100 \\
\hline St- $3, \mathrm{w}$ & - & - & - & - & - & - & - \\
\hline St- $2, \mathrm{w}$ & 69 & 30 & 1.00 & 0 & 0 & 0 & 100 \\
\hline St- $1, \mathrm{w}$ & 30 & 65 & 0 & 0 & 0 & 4 & 100 \\
\hline St-11,c & 13 & 83 & 0 & 0 & 0 & 4 & 100 \\
\hline St-10,c & 19 & 81 & 0 & 0 & 0 & 0 & 100 \\
\hline St- $9, \mathrm{c}$ & 7 & 90 & 0 & 0 & 0 & 0 & 100 \\
\hline St- $8, \mathrm{c}$ & 1 & 99 & 0 & 0 & 0 & 0 & 100 \\
\hline St- 7,c & 49 & 51 & 0 & 0 & 0 & 0 & 100 \\
\hline St- 6,c & 57 & 43 & 0 & 0 & 0 & 0 & 100 \\
\hline St- 5,c & 19 & 81 & 0 & 0 & 0 & 0 & 100 \\
\hline St- $4, c$ & - & - & - & - & - & - & - \\
\hline St- $3, \mathrm{c}$ & 32 & 61 & 0 & 0 & 0 & 8 & 100 \\
\hline St- $2, \mathrm{c}$ & 50 & 48 & 1.00 & 0 & 0 & 1 & 100 \\
\hline St- $1, \mathrm{c}$ & 33 & 67 & 0 & 0 & 0 & 0 & 100 \\
\hline
\end{tabular}


Acritarch groups Ratio:

(Polygonomorphitae + Netromorphitae)/Acanthomorphitae

\begin{tabular}{lc}
\hline Sample & $\begin{array}{c}\text { Ratio: } \\
(\mathrm{P}+\mathrm{N}) / \mathrm{A}\end{array}$ \\
no. & 0.00 \\
\hline St-16,w & 0.18 \\
St-15,w & 0.23 \\
St-14,w & 0.21 \\
St-13,w & - \\
St-12,w & 0.52 \\
St-11,w & - \\
St-10,w & 0.67 \\
St- 9,w & 0.40 \\
St- $8, \mathrm{w}$ & 0.00 \\
St- 7,w & 0.85 \\
St- 6,w & 0.38 \\
St- 5,w & 0.41 \\
St- 4,w & - \\
St- 3,w & 0.18 \\
St- 2,w & 0.15 \\
St- 1,w & 0.19 \\
St-11,c & 0.44 \\
St-10,c & 0.00 \\
St- 9,c & 2.35 \\
St- 8,c & 0.13 \\
St- 7,c & 0.12 \\
St- 6,c & 0.00 \\
St- 5,c & - \\
St- $4, \mathrm{c}$ & 0.92 \\
St- 3,c & 0.03 \\
St- 2,c & 0.00 \\
St- 1,c & \\
\hline & \\
& \\
&
\end{tabular}

Mean values of the kerogen categories for each lithostratigraphical unit.

\begin{tabular}{|c|c|c|c|c|c|c|c|c|c|c|c|c|}
\hline & \multicolumn{2}{|c|}{$\mathrm{Fj} . \mathrm{F}$. } & \multicolumn{2}{|c|}{ Ga. F. } & \multicolumn{2}{|c|}{ F-Ia M. } & \multicolumn{2}{|c|}{ F-II M. } & \multicolumn{2}{|c|}{ F-III M. } & \multicolumn{2}{|c|}{ F-IV M. } \\
\hline & mean & $\mathrm{n}$ & mean & $\mathrm{n}$ & mean & $n$ & mean & $\mathrm{n}$ & mean & $\mathrm{n}$ & mean & $\mathrm{n}$ \\
\hline T.O.C. & 1.0 & 25 & 2.6 & 2 & 1.0 & 19 & 0.8 & 4 & 1.9 & 1 & 0.4 & 1 \\
\hline$\%$ palynomorphs & 18 & 24 & 11 & 2 & 13 & 18 & 39 & 4 & 22 & 1 & 16 & 1 \\
\hline \% brown wood & 68 & 24 & 74 & 2 & 76 & 18 & 48 & 4 & 1 & 1 & 63 & 1 \\
\hline$\%$ black wood & 6 & 24 & 11 & 2 & 7 & 18 & 7 & 4 & 0 & 1 & 1 & 1 \\
\hline$\%$ cuticle & 0 & 24 & 0 & 2 & 0 & 18 & 0 & 4 & 0 & 1 & 2 & 1 \\
\hline \% A.O.M. & 8 & 24 & 4 & 2 & 3 & 18 & 6 & 4 & 76 & 1 & 18 & 1 \\
\hline PhytOC & 0.64 & 24 & 2.24 & 2 & 0.75 & 18 & 0.41 & 4 & 0.03 & 1 & 0.25 & 1 \\
\hline AmexOC & 0.09 & 24 & 0.11 & 2 & 0.33 & 18 & 0.05 & 4 & 1.42 & 1 & 0.07 & 1 \\
\hline$\%$ marine palynom. & 11 & 21 & 25 & 2 & 10 & 16 & 19 & 3 & 7 & 1 & 3 & 1 \\
\hline$\%$ spores & 49 & 21 & 18 & 2 & 58 & 16 & 28 & 3 & 1 & 1 & 22 & 1 \\
\hline$\%$ saccate pollen & 17 & 21 & 6 & 2 & 16 & 16 & 32 & 3 & 0 & 1 & 0 & 1 \\
\hline$\%$ non-sac. pollen & 34 & 21 & 76 & 2 & 26 & 16 & 40 & 3 & 99 & 1 & 78 & 1 \\
\hline sac. pollen/spores & 0.43 & 21 & 0.23 & 2 & 0.29 & 16 & 1.15 & 3 & 0.00 & 1 & 0.00 & 1 \\
\hline$\%$ dinofl. cysts & 20 & 21 & 42 & 2 & 24 & 16 & 5 & 3 & 14 & 1 & 0 & 1 \\
\hline$\%$ acritarchs & 78 & 21 & 57 & 2 & 74 & 16 & 91 & 3 & 68 & 1 & 100 & 1 \\
\hline$\%$ Tasmanaceae & 0 & 21 & 0 & 2 & 0 & 16 & 0 & 3 & 0 & 1 & 0 & 1 \\
\hline$\%$ Pterospermel. & 1 & 21 & 0 & 2 & 0 & 16 & 1 & 3 & 18 & 1 & 0 & 1 \\
\hline \% Cymatiosph. & 1 & 21 & 0 & 2 & 0 & 16 & 1 & 3 & 9 & 1 & 0 & 1 \\
\hline$\%$ foram.testl. & 0 & 21 & 0 & 2 & 0 & 16 & 0 & 3 & 0 & 1 & 0 & 1 \\
\hline$\%$ limnic algae & 1 & 21 & 1 & 2 & 1 & 16 & 3 & 3 & 0 & 1 & 0 & 1 \\
\hline$(P+N) / A$ & 0.26 & 21 & 0.02 & 2 & 0.28 & 16 & 0.32 & 3 & 0.00 & 1 & 0.00 & 1 \\
\hline
\end{tabular}




\section{Appendix D \\ The Gassum-1 borehole}

Kerogen categories

Relative abundances

\begin{tabular}{|c|c|c|c|c|c|}
\hline \multirow[t]{2}{*}{$\begin{array}{l}\text { Lithostrat. } \\
\text { units }\end{array}$} & \multirow{2}{*}{$\begin{array}{l}\begin{array}{l}\text { Sample } \\
\text { no. }\end{array} \\
\text { GA-60,c }\end{array}$} & \multirow{2}{*}{$\begin{array}{l}\begin{array}{l}\text { Depth } \\
\text { (m.b.r.t.) }\end{array} \\
1210\end{array}$} & \multicolumn{2}{|l|}{$\begin{array}{l}\text { Sample } \\
\text { lithology }\end{array}$} & T.O.C \\
\hline & & & si.cl.st. & $\psi \sim$ & 1.2 \\
\hline & GA- $58, \mathrm{c}$ & 1227 & si.cl.st. & $\psi \sim$ & 1.1 \\
\hline \multirow[t]{4}{*}{ F-III Mb. } & GA-57,c & 1245 & clayst. & & 1.4 \\
\hline & GA-55,c & 1264 & si.cl.st. & & 1.2 \\
\hline & GA-53,c & 1277 & si.cl.st. & $\psi$ & 1.7 \\
\hline & GA-52,c & 1289 & si.cl.st. & $\sim$ & 1.6 \\
\hline \multirow[t]{8}{*}{ F-II Mb. } & GA-51,c & 1301 & clayst. & $\sim$ & 1.1 \\
\hline & GA- $49, \mathrm{c}$ & 1303 & clayst. & & 1.3 \\
\hline & GA-47,c & 1305 & si.cl.st. & $\sim$ & 1.2 \\
\hline & $\mathrm{GA}-44, \mathrm{c}$ & 1313 & clayst. & $\psi \sim$ & 1.0 \\
\hline & $\mathrm{GA}-42, \mathrm{c}$ & 1327 & clayst. & & 1.0 \\
\hline & $\mathrm{GA}-41, \mathrm{c}$ & 1342 & clayst. & & 1.1 \\
\hline & GA- $40, c$ & 1358 & clayst. & & 0.9 \\
\hline & GA-38,c & 1360 & clayst. & & 0.8 \\
\hline \multirow[t]{11}{*}{ F-Ib Mb. } & GA-37,c & 1361 & clayst. & $\sim$ & 0.7 \\
\hline & GA-36,c & 1373 & clayst. & & 0.7 \\
\hline & GA-35,c & 1373 & si.cl.st. & $\sim$ & 0.6 \\
\hline & GA-33,c & 1376 & clayst. & & 1.0 \\
\hline & GA-31,c & 1390 & clayst. & & 1.0 \\
\hline & GA-29,c & 1404 & clayst. & & 0.9 \\
\hline & GA-26,c & 1420 & clayst. & & 1.0 \\
\hline & GA-24,c & 1434 & clayst. & & 0.9 \\
\hline & GA-22,c & 1437 & clayst. & & 1.1 \\
\hline & GA-20,c & 1439 & si.cl.st. & $\psi$ & 0.4 \\
\hline & GA-19,c & 1450 & clayst. & & 0.8 \\
\hline \multirow[t]{9}{*}{ F-Ia Mb. } & GA-18,c & 1464 & clayst. & & 0.9 \\
\hline & GA-16,c & 1467 & clayst. & $\sim$ & 0.7 \\
\hline & GA-14,c & 1480 & si.cl.st. & $\psi$ & 0.7 \\
\hline & GA-12,c & 1484 & clayst. & & 0.6 \\
\hline & GA- $10, c$ & 1497 & clayst. & & 0.5 \\
\hline & GA- $8, \mathrm{c}$ & 1498 & clayst. & & 0.7 \\
\hline & GA- $6, \mathrm{c}$ & 1511 & clayst. & & 1.0 \\
\hline & GA- 4,c & 1513 & clayst. & & 1.0 \\
\hline & GA- 3,c & 1534 & clayst. & & 1.5 \\
\hline Gassum & GA- 2,c & 1534 & sa.cl.st. & & 0.9 \\
\hline $\mathrm{Fm}$ & GA- $1, \mathrm{c}$ & 1536 & si.cl.st. & & 1.4 \\
\hline
\end{tabular}

Sample Paly- Br. Bl. Cuticle A.O.M. Total

nom. wood wood

$\% \quad \% \quad \%$
$\%$

\begin{tabular}{lllllll}
\hline GA-60,c & 47 & 27 & 10 & 0 & 16 & 100
\end{tabular}

$\begin{array}{lllllll}\text { GA-58,c } & 42 & 33 & 23 & 0 & 2 & 100\end{array}$

$\begin{array}{lllllll}\text { GA }-57, \mathrm{c} & 20 & 58 & 20 & 0 & 3 & 100\end{array}$

$\begin{array}{lllllll}\text { GA- } 55, \mathrm{c} & 31 & 36 & 31 & 0 & 2 & 100\end{array}$

$\begin{array}{lllllll}\text { GA- } 53, \mathrm{c} & 19 & 59 & 21 & 0 & 0 & 100\end{array}$

$\begin{array}{lllllll}\text { GA-52,c } & 46 & 30 & 9 & 0 & 15 & 100\end{array}$

$\begin{array}{lllllll}\text { GA-51,c } & 70 & 15 & 7 & 0 & 9 & 100\end{array}$

$\begin{array}{lllllll}\text { GA-49,c } & 42 & 24 & 13 & 0 & 21 & 100\end{array}$

$\begin{array}{lllrlll}\mathrm{GA}-47, \mathrm{c} & 55 & 20 & 7 & 0 & 18 & 100\end{array}$

$\begin{array}{lllllll}\text { GA-44,c } & 58 & 23 & 11 & 0 & 8 & 100\end{array}$

$\begin{array}{lllllll}\text { GA-42,c } & 33 & 30 & 36 & 0 & 2 & 100\end{array}$

$\begin{array}{lllllll}\text { GA-41,c } & 15 & 29 & 54 & 0 & 2 & 100\end{array}$

$\begin{array}{lllllll}\text { GA-40,c } & 24 & 34 & 39 & 0 & 3 & 100\end{array}$

$\begin{array}{lllllll}\text { GA-38,c } & 18 & 45 & 33 & 0 & 4 & 100\end{array}$

$\begin{array}{lllllll}\text { GA-37,c } & 27 & 33 & 38 & 0 & 1 & 100\end{array}$

$\begin{array}{lllllll}\text { GA-36,c } & 19 & 40 & 39 & 0 & 1 & 100\end{array}$

$\begin{array}{lllllll}\text { GA-35,c } & 49 & 33 & 17 & 0 & 1 & 100\end{array}$

$\begin{array}{lllllll}\text { GA-33,c } & 22 & 36 & 4 & 0 & 9 & 100\end{array}$

$\begin{array}{lllllll}\text { GA-31,c } & 25 & 37 & 33 & 0 & 4 & 100\end{array}$

$\begin{array}{lllllll}\text { GA-29,c } & 22 & 38 & 35 & 0 & 4 & 100\end{array}$

$\begin{array}{lllllll}\text { GA-26,c } & 26 & 34 & 30 & 0 & 10 & 100\end{array}$

$\begin{array}{lllllll}\text { GA-24,c } & 36 & 33 & 22 & 0 & 9 & 100\end{array}$

$\begin{array}{lllllll}\text { GA-22,c } & 24 & 37 & 29 & 0 & 10 & 100\end{array}$

$\begin{array}{lllllll}\text { GA-20,c } & 21 & 35 & 35 & 0 & 8 & 100\end{array}$

$\begin{array}{lllllll}\text { GA-19,c } & 37 & 43 & 17 & 0 & 3 & 100\end{array}$

$\begin{array}{lllllll}\text { GA-18,c } & 22 & 50 & 25 & 0 & 3 & 100\end{array}$

$\begin{array}{lllllll}\text { GA-16,c } & 28 & 40 & 27 & 1 & 4 & 100\end{array}$

$\begin{array}{lllllll}\text { GA-14,c } & 20 & 41 & 37 & 0 & 1 & 100\end{array}$

$\begin{array}{lllllll}\text { GA-12,c } & 21 & 42 & 33 & 0 & 4 & 100\end{array}$

$\begin{array}{lllllll}\text { GA-10,c } & 22 & 37 & 39 & 0 & 3 & 100\end{array}$

$\begin{array}{lllllll}\text { GA- } 8, \mathrm{c} & 16 & 41 & 26 & 0 & 18 & 100\end{array}$

$\begin{array}{lllllll}\text { GA- } 6, \mathrm{c} & 24 & 36 & 31 & 0 & 9 & 100\end{array}$

$\begin{array}{lllllll}\text { GA. } 4, \mathrm{c} & 24 & 30 & 35 & 0 & 11 & 100\end{array}$

$\begin{array}{lllllll}\text { GA- } 3, \mathrm{c} & 9 & 64 & 25 & 1 & 1 & 100\end{array}$

$\begin{array}{lllllll}\text { GA- } 2, \mathrm{c} & 19 & 69 & 10 & 0 & 3 & 100\end{array}$

$\begin{array}{lllllll}\text { GA- } 1, \mathrm{c} & 16 & 43 & 36 & 2 & 3 & 100\end{array}$

$\psi:$ plant remains

$\sim$ : clay-ironstone

clayst.: claystone

si.cl.st.: silt-streaked claystone

sa.cl.st.: sand-streaked claystone 
Brown wood, size groups, relative abundances $100 \%=$ total of brown wood

\begin{tabular}{|c|c|c|c|c|c|c|c|c|c|}
\hline $\begin{array}{l}\text { Sample } \\
\text { no. }\end{array}$ & $\begin{array}{c}<20 \\
\text { microns } \\
\%\end{array}$ & $\begin{array}{c}20-80 \\
\text { microns } \\
\%\end{array}$ & $\begin{array}{c}>80 \\
\text { microns } \\
\%\end{array}$ & $\begin{array}{c}\text { Total } \\
\%\end{array}$ & $\begin{array}{l}\text { Sample } \\
\text { no. }\end{array}$ & $\begin{array}{c}<20 \\
\text { microns } \\
\%\end{array}$ & $\begin{array}{c}20-80 \\
\text { microns } \\
\%\end{array}$ & $\begin{array}{c}>80 \\
\text { microns } \\
\%\end{array}$ & $\begin{array}{c}\text { Total } \\
\%\end{array}$ \\
\hline GA-60,c & 28 & 66 & 6 & 100 & GA- $60, c$ & 58 & 38 & 4 & 100 \\
\hline GA-58,c & 16 & 81 & 3 & 100 & GA-58,c & 27 & 71 & 2 & 100 \\
\hline GA-57,c & 36 & 63 & 1 & 100 & GA-57,c & 62 & 35 & 3 & 100 \\
\hline GA-55,c & 27 & 65 & 9 & 100 & GA-55,c & 51 & 45 & 4 & 100 \\
\hline GA-53,c & 45 & 51 & 4 & 100 & $\mathrm{GA}-53, \mathrm{c}$ & 56 & 41 & 3 & 100 \\
\hline GA-52,c & 13 & 80 & 7 & 100 & $\mathrm{GA}-52, \mathrm{c}$ & 18 & 78 & 4 & 100 \\
\hline GA-51,c & 14 & 75 & 11 & 100 & GA-51,c & 61 & 39 & 0 & 100 \\
\hline GA-49,c & 26 & 65 & 9 & 100 & GA- $49, c$ & 41 & 51 & 8 & 100 \\
\hline GA-47,c & 26 & 66 & 8 & 100 & GA-47,c & 32 & 61 & 7 & 100 \\
\hline GA-44,c & 23 & 69 & 8 & 100 & $\mathrm{GA}-44, \mathrm{c}$ & 31 & 56 & 13 & 100 \\
\hline GA-42,c & 6 & 91 & 3 & 100 & $\mathrm{GA}-42, \mathrm{c}$ & 35 & 63 & 2 & 100 \\
\hline GA-40,c & 18 & 81 & 2 & 100 & GA-40,c & 31 & 69 & 0 & 100 \\
\hline GA-38,c & 27 & 70 & 3 & 100 & GA-38,c & 46 & 54 & 0 & 100 \\
\hline GA-37,c & 16 & 77 & 7 & 100 & GA-37,c & 31 & 67 & 2 & 100 \\
\hline GA-36,c & 25 & 68 & 6 & 100 & GA-36,c & 53 & 46 & 1 & 100 \\
\hline GA-35,c & 21 & 74 & 6 & 100 & GA-35,c & 31 & 67 & 2 & 100 \\
\hline GA-33,c & 25 & 70 & 5 & 100 & GA-33,c & 44 & 55 & 2 & 100 \\
\hline $\mathrm{GA}-31, \mathrm{c}$ & 27 & 69 & 4 & 100 & $\mathrm{GA}-31, \mathrm{c}$ & 49 & 50 & 1 & 100 \\
\hline $\mathrm{GA}-29, \mathrm{c}$ & 23 & 72 & 5 & 100 & $\mathrm{GA}-29, \mathrm{c}$ & 48 & 49 & 2 & 100 \\
\hline $\mathrm{GA}-26, \mathrm{c}$ & 24 & 69 & 7 & 100 & $\mathrm{GA}-26, \mathrm{c}$ & 57 & 41 & 2 & 100 \\
\hline $\mathrm{GA}-24, \mathrm{c}$ & 20 & 69 & 12 & 100 & $\mathrm{GA}-24, \mathrm{c}$ & 43 & 54 & 3 & 100 \\
\hline GA-22,c & 32 & 63 & 5 & 100 & GA-22,c & 55 & 44 & 1 & 100 \\
\hline GA-20,c & 44 & 53 & 4 & 100 & GA-20,c & 52 & 47 & 1 & 100 \\
\hline GA-19,c & 42 & 56 & 2 & 100 & GA-19,c & 55 & 44 & 1 & 100 \\
\hline GA-18,c & 33 & 64 & 3 & 100 & GA-18,c & 47 & 51 & 2 & 100 \\
\hline GA-12,c & 25 & 71 & 4 & 100 & GA-12,c & 32 & 66 & 2 & 100 \\
\hline GA-10,c & 33 & 59 & 7 & 100 & GA-10,c & 48 & 48 & 3 & 100 \\
\hline GA- $8, c$ & 33 & 64 & 4 & 100 & GA- $8, c$ & 52 & 45 & 3 & 100 \\
\hline GA- $6, c$ & 23 & 69 & 8 & 100 & GA- $6, c$ & 39 & 51 & 11 & 100 \\
\hline $\mathrm{GA}-4, \mathrm{c}$ & 24 & 62 & 13 & 100 & GA- $4, c$ & 36 & 59 & 5 & 100 \\
\hline GA- 3,c & 27 & 70 & 2 & 100 & GA- $3, \mathrm{c}$ & 39 & 59 & 2 & 100 \\
\hline GA- $2, c$ & 34 & 63 & 3 & 100 & GA- 2,c & 55 & 43 & 2 & 100 \\
\hline GA- $1, c$ & 34 & 64 & 2 & 100 & GA- $1, \mathrm{c}$ & 58 & 41 & 1 & 100 \\
\hline
\end{tabular}


Kerogen categories

Absolute abundance

\begin{tabular}{|c|c|c|c|c|c|c|c|c|c|c|c|c|}
\hline $\begin{array}{l}\text { Sample } \\
\text { no. }\end{array}$ & $\begin{array}{l}\text { Palyno- } \\
\text { morphs }\end{array}$ & $\begin{array}{l}\text { Brown } \\
\text { wood }\end{array}$ & $\begin{array}{c}<20 \\
\text { microns }\end{array}$ & $\begin{array}{c}20-80 \\
\text { microns }\end{array}$ & $\begin{array}{c}>80 \\
\text { microns }\end{array}$ & $\begin{array}{l}\text { Black } \\
\text { wood }\end{array}$ & $\begin{array}{c}<20 \\
\text { microns }\end{array}$ & $\begin{array}{c}20-80 \\
\text { microns }\end{array}$ & $\begin{array}{c}>80 \\
\text { microns }\end{array}$ & Cuticle & A.O.M & $\mathbf{n}$ \\
\hline GA- $60, c$ & 248 & 145 & 41 & 95 & 9 & 55 & 32 & 21 & 2 & 0 & 83 & 531 \\
\hline GA-58,c & 268 & 210 & 33 & 170 & 7 & 148 & 40 & 105 & 3 & 2 & 15 & 643 \\
\hline GA-57,c & 108 & 310 & 112 & 194 & 4 & 106 & 66 & 37 & 3 & 1 & 14 & 539 \\
\hline GA-55,c & 166 & 195 & 52 & 126 & 17 & 170 & 87 & 77 & 6 & 1 & 11 & 543 \\
\hline GA- $53, \mathrm{c}$ & 103 & 316 & 143 & 161 & 12 & 114 & 64 & 47 & 3 & 1 & 0 & 534 \\
\hline GA-52,c & 267 & 172 & 22 & 138 & 12 & 50 & 9 & 39 & 2 & 0 & 89 & 578 \\
\hline GA-51,c & 384 & 80 & 11 & 60 & 9 & 36 & 22 & 14 & 0 & 1 & 48 & 549 \\
\hline GA-49,c & 243 & 141 & 37 & 91 & 13 & 76 & 31 & 39 & 6 & 1 & 120 & 581 \\
\hline GA-47,c & 320 & 119 & 31 & 78 & 10 & 44 & 14 & 27 & 3 & 0 & 104 & 587 \\
\hline GA- $44, \mathrm{c}$ & 329 & 133 & 30 & 92 & 11 & 61 & 19 & 34 & 8 & 1 & 43 & 567 \\
\hline GA-42,c & 186 & 170 & 10 & 155 & 5 & 203 & 71 & 128 & 4 & 0 & 10 & 569 \\
\hline GA-41,c & 84 & 164 & 46 & 111 & 7 & 299 & 112 & 182 & 5 & 0 & 11 & 558 \\
\hline GA-40,c & 153 & 217 & 38 & 175 & 4 & 248 & 76 & 171 & 1 & 1 & 18 & 637 \\
\hline GA-38,c & 92 & 237 & 65 & 166 & 6 & 171 & 79 & 92 & 0 & 0 & 21 & 521 \\
\hline GA-37,c & 141 & 169 & 27 & 130 & 12 & 196 & 60 & 132 & 4 & 0 & 7 & 513 \\
\hline GA-36,c & 105 & 220 & 56 & 150 & 14 & 215 & 115 & 98 & 2 & 2 & 7 & 549 \\
\hline GA-35,c & 278 & 185 & 38 & 136 & 11 & 95 & 29 & 64 & 2 & 1 & 5 & 564 \\
\hline GA-33,c & 122 & 200 & 50 & 140 & 10 & 190 & 83 & 104 & 3 & 0 & 50 & 562 \\
\hline GA-31,c & 136 & 199 & 54 & 138 & 7 & 179 & 88 & 90 & 1 & 2 & 22 & 538 \\
\hline GA-29,c & 125 & 215 & 50 & 154 & 11 & 198 & 96 & 98 & 4 & 0 & 25 & 563 \\
\hline GA-26,c & 139 & 178 & 42 & 123 & 13 & 156 & 89 & 64 & 3 & 0 & 53 & 526 \\
\hline GA-24,c & 195 & 179 & 35 & 123 & 21 & 119 & 51 & 64 & 4 & 1 & 46 & 540 \\
\hline GA-22,c & 136 & 206 & 66 & 129 & 11 & 165 & 91 & 73 & 1 & 0 & 55 & 562 \\
\hline GA-20,c & 116 & 200 & 87 & 105 & 8 & 200 & 104 & 94 & 2 & 1 & 48 & 565 \\
\hline GA-19,c & 208 & 240 & 101 & 135 & 4 & 97 & 53 & 43 & 1 & 0 & 17 & 562 \\
\hline GA-18,c & 118 & 273 & 89 & 175 & 9 & 133 & 63 & 68 & 2 & 1 & 17 & 542 \\
\hline GA-16,c & 152 & 215 & 51 & 152 & 12 & 146 & 73 & 73 & 0 & 3 & 20 & 536 \\
\hline GA-14,c & 107 & 221 & 55 & 156 & 10 & 197 & 72 & 117 & 8 & 2 & 8 & 535 \\
\hline GA-12,c & 121 & 248 & 61 & 177 & 10 & 193 & 61 & 128 & 4 & 2 & 23 & 587 \\
\hline $\mathrm{GA}-10, \mathrm{c}$ & 132 & 222 & 74 & 132 & 16 & 233 & 112 & 113 & 8 & 0 & 17 & 604 \\
\hline GA- $8, c$ & 85 & 215 & 70 & 137 & 8 & 136 & 71 & 61 & 4 & 0 & 94 & 530 \\
\hline GA- $6, c$ & 152 & 232 & 53 & 160 & 19 & 198 & 77 & 100 & 21 & 1 & 61 & 644 \\
\hline GA- $4, c$ & 158 & 194 & 47 & 121 & 26 & 226 & 81 & 134 & 11 & 1 & 72 & 651 \\
\hline GA- 3,c & 72 & 486 & 133 & 341 & 12 & 194 & 76 & 115 & 3 & 4 & 7 & 763 \\
\hline GA- $2, \mathrm{c}$ & 97 & 361 & 124 & 226 & 11 & 51 & 28 & 22 & 1 & 0 & 15 & 524 \\
\hline GA- $1, \mathrm{c}$ & 83 & 228 & 77 & 146 & 5 & 193 & 111 & 80 & 2 & 9 & 17 & 530 \\
\hline
\end{tabular}


Terrestrial palynomorphs Relative abundances

\begin{tabular}{|c|c|c|c|c|c|c|c|c|}
\hline \multirow[t]{2}{*}{$\begin{array}{l}\text { Sample } \\
\text { no. }\end{array}$} & \multirow[t]{2}{*}{ PhytOC } & \multirow{2}{*}{ AmexOC } & \multirow{2}{*}{$\begin{array}{c}\text { Marine } \\
\text { palynom. } \\
\%\end{array}$} & \multirow{2}{*}{$\begin{array}{l}\text { Ratio: } \\
\text { saccate } \\
\text { pollen/ } \\
\text { spores }\end{array}$} & \multirow{2}{*}{$\begin{array}{c}\text { Ratio: } \\
(\mathbf{P}+\mathbf{N}) / \\
\text { A }\end{array}$} & $\begin{array}{l}\text { Depth } \\
\text { (m b.r.t.) }\end{array}$ & $\begin{array}{l}\text { Individ. Ostracod } \\
\text { ostrac. } / 100 \mathrm{gsed} .\end{array}$ & \multirow[t]{2}{*}{$\begin{array}{l}\text { Ostracod species } \\
\text { diversity }\end{array}$} \\
\hline & & & & & & 1210 & 0 & \\
\hline & & & & & & 1224 & 33 & 6 \\
\hline GA-60,c & 0.46 & 0.19 & 22 & 0.80 & 0.19 & 1225 & 37 & 6 \\
\hline GA-58,c & 0.59 & 0.02 & - & - & - & 1226 & 21 & 4 \\
\hline GA-57,c & 1.06 & 0.04 & 11 & 0.59 & 0.37 & 1227 & 50 & 4 \\
\hline GA-55,c & 0.80 & 0.02 & 23 & 1.34 & 0.06 & 1244 & 97 & 2 \\
\hline GA- $53, \mathrm{c}$ & 1.37 & 0.00 & 4 & 0.32 & 0.00 & 1246 & 4 & 0 \\
\hline GA-52,c & 0.60 & 0.24 & - & - & - & 1248 & 1 & - \\
\hline GA-51,c & 0.24 & 0.10 & 34 & 1.59 & 0.05 & 1264 & 74 & 6 \\
\hline GA- $49, \mathrm{c}$ & 0.47 & 0.26 & 32 & 1.98 & 0.10 & 1278 & 38 & 10 \\
\hline GA- $47, \mathrm{c}$ & 0.32 & 0.21 & 21 & 1.58 & 0.05 & 1287 & 33 & 3 \\
\hline GA- $44, c$ & 0.34 & 0.07 & 31 & 1.84 & 0.04 & 1290 & 13 & 3 \\
\hline GA-42,c & 0.68 & 0.02 & - & - & - & 1300 & 2 & - \\
\hline GA-41,c & 0.91 & 0.02 & 7 & 0.28 & 0.05 & 1302 & 4 & 2 \\
\hline GA-40,c & 0.68 & 0.03 & - & - & - & 1305 & 2 & 1 \\
\hline GA-38,c & 0.61 & 0.03 & 18 & 0.47 & 0.02 & 1307 & 1 & - \\
\hline GA-37,c & 0.46 & 0.01 & - & - & - & 1311 & 10 & 14 \\
\hline GA-36,c & 0.59 & 0.01 & 31 & 0.48 & 0.03 & 1312 & 31 & 14 \\
\hline GA-35,c & 0.31 & 0.01 & - & - & - & 1314 & 0 & - \\
\hline GA-33,c & 0.72 & 0.09 & 24 & 1.67 & 0.04 & 1326 & 3 & 0 \\
\hline GA-31,c & 0.68 & 0.04 & 34 & 0.79 & 0.17 & 1328 & 1 & - \\
\hline GA-29,c & 0.67 & 0.04 & 18 & 0.83 & 0.27 & 1341 & 1 & - \\
\hline GA-26,c & 0.63 & 0.10 & 25 & 1.00 & 0.11 & 1347 & 5 & 2 \\
\hline GA-24,c & 0.48 & 0.07 & 30 & 0.72 & 0.33 & 1357 & 8 & 3 \\
\hline GA-22,c & 0.72 & 0.11 & 27 & 1.04 & 0.05 & 1359 & 9 & 3 \\
\hline GA-20,c & 0.31 & 0.04 & 15 & 0.47 & 0.13 & 1360 & 2 & - \\
\hline GA-19,c & 0.50 & 0.03 & - & - & - & 1362 & 3 & - \\
\hline GA-18,c & 0.64 & 0.03 & 16 & 0.15 & 1.19 & 1372 & 1 & - \\
\hline GA-16,c & 0.44 & 0.02 & 11 & 0.26 & 0.26 & 1404 & 22 & 1 \\
\hline GA-14,c & 0.52 & 0.01 & 11 & 0.32 & 0.10 & 1404 & 9 & 1 \\
\hline GA-12,c & 0.45 & 0.02 & 6 & 0.47 & 0.14 & 1405 & 8 & 2 \\
\hline GA-10,c & 0.41 & 0.02 & 41 & 0.88 & 0.04 & 1405 & 31 & 1 \\
\hline GA- $8, c$ & 0.48 & 0.13 & 19 & 0.56 & 0.04 & 1406 & 3 & 1 \\
\hline GA- $6, c$ & 0.65 & 0.09 & 28 & 2.50 & 0.05 & 1406 & 4 & 1 \\
\hline GA- $4, \mathrm{c}$ & 0.62 & 0.11 & 36 & 1.28 & 0.17 & 1407 & 7 & 1 \\
\hline GA- $3, \mathrm{c}$ & 1.37 & 0.01 & 5 & 0.05 & 0.00 & 1407 & 2 & 1 \\
\hline GA- $2, \mathrm{c}$ & 0.71 & 0.03 & - & - & - & 1417 & 231 & 3 \\
\hline GA- $1, c$ & 1.13 & 0.04 & 0 & 0.11 & 0.00 & 1419 & 337 & 3 \\
\hline PhytOC = & rown woo & $\mathrm{bd}+\%$ blac & ck wood + & $\%$ cuticle & $\times$ T.O.C. & $\begin{array}{l}1421 \\
1423\end{array}$ & $\begin{array}{r}1 \\
25\end{array}$ & - \\
\hline AmexOC & Amorphou & us Organic & & & & 1434 & 28 & 3 \\
\hline Matter (A & I.) $\times$ T.O. & & & & & 1436 & 64 & 2 \\
\hline$\%$ marine & omorphs: & $100 \%=\mathrm{tc}$ & otal palyno & morphs & & 1438 & 10 & 6 \\
\hline & & & & & & 1439 & 25 & 0 \\
\hline & & & & & & 1440 & 1333 & 2 \\
\hline & & & & & & 1451 & 102 & 3 \\
\hline & & & & & & 1463 & 11 & 2 \\
\hline & & & & & & 1470 & 403 & 1 \\
\hline & & & & & & 1479 & 23 & 2 \\
\hline & & & & & & 1485 & 35 & 2 \\
\hline & & & & & & 1497 & 19 & 2 \\
\hline & & & & & & 1509 & 41 & 1 \\
\hline & & & & & & 1512 & 4 & 3 \\
\hline & & & & & & 1515 & 11 & 1 \\
\hline
\end{tabular}

Number of ostracods per $100 \mathrm{~g}$ sediment, and ostracod diversity, according to Michelsen (1975) 
Mean values of the kerogen categories for each lithostratigraphical unit.

\begin{tabular}{|c|c|c|c|c|c|c|c|c|c|c|c|c|}
\hline & \multicolumn{2}{|c|}{ Fj. F. } & \multicolumn{2}{|c|}{ Ga. F. } & \multicolumn{2}{|c|}{ F-Ia M. } & \multicolumn{2}{|c|}{ F-Ib M. } & \multicolumn{2}{|c|}{ F-II M. } & \multicolumn{2}{|c|}{ F-III M. } \\
\hline & mean & $\mathbf{n}$ & mean & $\mathbf{n}$ & mean & $\mathbf{n}$ & mean & $\mathbf{n}$ & mean & $\mathrm{n}$ & mean & $\mathbf{n}$ \\
\hline T.O.C. & 1.0 & 33 & 1.3 & 3 & 0.8 & 13 & 0.9 & 11 & 1.4 & 5 & 1.2 & 4 \\
\hline \%palynomorphs & 30 & 33 & 15 & 3 & 25 & 13 & 28 & 11 & 51 & 5 & 35 & 4 \\
\hline \% brown wood & 36 & 33 & 59 & 3 & 38 & 13 & 34 & 11 & 22 & 5 & 38 & 4 \\
\hline$\%$ black wood & 27 & 33 & 24 & 3 & 30 & 13 & 33 & 11 & 11 & 5 & 21 & 4 \\
\hline$\%$ cuticle & 0 & 33 & 1 & 3 & 0 & 13 & 0 & 11 & 0 & 5 & 0 & 4 \\
\hline$\%$ A.O.M. & 7 & 33 & 2 & 3 & 7 & 13 & 4 & 11 & 13 & 5 & 6 & 4 \\
\hline PhytOC & 0.59 & 33 & 1.07 & 3 & 0.53 & 13 & 0.60 & 11 & 0.60 & 5 & 0.55 & 4 \\
\hline AmexOC & 0.07 & 33 & 0.03 & 3 & 0.06 & 13 & 0.03 & 11 & 0.16 & 5 & 0.07 & 4 \\
\hline$\%$ marine palynom. & 22 & 26 & 3 & 2 & 22 & 12 & 10 & 7 & 23 & 40 & 19 & 3 \\
\hline$\%$ spores & 32 & 26 & 84 & 2 & 41 & 12 & 28 & 7 & 21 & 4 & 25 & 3 \\
\hline$\%$ saccate pollen & 21 & 26 & 6 & 2 & 23 & 12 & 19 & 7 & 23 & 4 & 20 & 3 \\
\hline$\%$ non-sac. pollen & 47 & 26 & 9 & 2 & 37 & 12 & 53 & 7 & 57 & 4 & 56 & 3 \\
\hline sac. pollen/spores & 0.93 & 26 & 0.08 & 2 & 0.80 & 12 & 0.91 & 7 & 1.37 & 4 & 0.91 & 3 \\
\hline$\%$ dinofl. cysts & 7 & 26 & 4 & 2 & 5 & 12 & 10 & 7 & 6 & 4 & 8 & 3 \\
\hline$\%$ acritarchs & 89 & 26 & 96 & 2 & 93 & 12 & 87 & 7 & 83 & 4 & 87 & 3 \\
\hline$\%$ Tasmanaceae & 1 & 26 & 0 & 2 & 1 & 12 & 2 & 7 & 3 & 4 & 0 & 3 \\
\hline$\%$ Pterospermel. & 0 & 26 & 0 & 2 & 0 & 12 & 0 & 7 & 0 & 4 & 0 & 3 \\
\hline \% Cymatiosph. & 0 & 26 & 0 & 2 & 0 & 12 & 0 & 7 & 0 & 4 & 0 & 3 \\
\hline$\%$ foram.testl. & 0 & 26 & 0 & 2 & 0 & 12 & 0 & 7 & 0 & 4 & 0 & 3 \\
\hline$\%$ limnic algae & 2 & 26 & 0 & 2 & 1 & 12 & 0 & 7 & 8 & 4 & 4 & 3 \\
\hline$(P+N) / A$ & 0.16 & 26 & 0.00 & 2 & 0.22 & 12 & 0.09 & 7 & 0.05 & 4 & 0.21 & 3 \\
\hline Ostracods: Diversity & 70 & 1 & 49 & 59 & 42 & 18 & 60 & 28 & 46 & 5 & 22 & 7 \\
\hline Number $/ 100 \mathrm{~g}$ sed. & 11 & 1 & 55 & 72 & 148 & 19 & 20 & 36 & 13 & 7 & 35 & 9 \\
\hline
\end{tabular}




\section{Appendix E}

Variations of the relative abundances of kerogen categories between the lithostratigraphical units

\begin{tabular}{|c|c|c|c|c|c|c|}
\hline \multirow{2}{*}{$\begin{array}{l}\text { Kerogen } \\
\text { categories }\end{array}$} & \multirow[t]{2}{*}{ Borehole } & \multicolumn{5}{|c|}{ Lithostratigraphical units } \\
\hline & & $\mathrm{GA} \rightarrow$ F-Ia & $\mathrm{F}-\mathrm{Ia} \rightarrow \mathrm{F}-\mathrm{Ib}$ & $\mathrm{F}-\mathrm{Ib} \rightarrow \mathrm{F}-\mathrm{II}$ & F-II $\rightarrow$ F-III & F-III $\rightarrow$ F-IV \\
\hline & $\mathrm{Fj}$ & $0 \%$ & $-18 \%$ & & & $+24 \%$ \\
\hline \multirow[t]{3}{*}{$\%$ br. wood } & Frh & & & & $+1 \%$ & $+24 \%$ \\
\hline & St & $+2 \%$ & & & $-47 \%$ & $+62 \%$ \\
\hline & $\mathrm{Ga}$ & $-21 \%$ & $-4 \%$ & $-12 \%$ & $+8 \%$ & \\
\hline \multirow[t]{4}{*}{$\%$ bl. wood } & $\mathrm{Fj}$ & $-8 \%$ & $+9 \%$ & & & $+7 \%$ \\
\hline & Frh & & & & $-1 \%$ & \\
\hline & St & $-4 \%$ & & & $-7 \%$ & $+1 \%$ \\
\hline & $\mathrm{Ga}$ & $+6 \%$ & $+3 \%$ & $-22 \%$ & $+10 \%$ & \\
\hline \multirow[t]{4}{*}{$\%$ palyn. } & $\mathrm{Fj}$ & $+8 \%$ & $+8 \%$ & & & $-20 \%$ \\
\hline & Frh & & & & $0 \%$ & \\
\hline & St & $+2 \%$ & & & $-17 \%$ & $-6 \%$ \\
\hline & $\mathrm{Ga}$ & $+10 \%$ & $+4 \%$ & $+23 \%$ & $-11 \%$ & \\
\hline \multirow[t]{4}{*}{ PhytOC } & $\mathrm{Fj}$ & -0.14 & -0.13 & & & +0.49 \\
\hline & Frh & +0.05 & & & & \\
\hline & St & -1.49 & & & -0.38 & +0.22 \\
\hline & $\mathrm{Ga}$ & -0.54 & +0.07 & 0.05 & & \\
\hline \multirow[t]{4}{*}{ AmexOC } & $\mathrm{Fj}$ & +0.01 & -0.01 & & & -0.16 \\
\hline & Frh & & & & 0.00 & \\
\hline & St & -0.08 & & & +1.37 & -1.35 \\
\hline & $\mathrm{Ga}$ & +0.03 & -0.03 & +0.13 & -0.09 & \\
\hline \multirow[t]{4}{*}{$\%$ marine palynomorphs } & $\mathrm{Fj}$ & $-6 \%$ & $+16 \%$ & & & $-13 \%$ \\
\hline & Frh & & & & $+12 \%$ & \\
\hline & St & $-15 \%$ & & & $-12 \%$ & $-4 \%$ \\
\hline & $\mathrm{Ga}$ & $+19 \%$ & $-12 \%$ & $+13 \%$ & $-4 \%$ & \\
\hline \multirow[t]{4}{*}{ saccate pollen/sporer } & $\mathrm{Fj}$ & +0.33 & +0.92 & & & -1.38 \\
\hline & Frh & & & & -0.16 & \\
\hline & St & +0.06 & & & -1.15 & 0 \\
\hline & $\mathrm{Ga}$ & +0.72 & +0.11 & +0.46 & -0.46 & \\
\hline $\mathbf{P}+\mathbf{N}$ & $\mathbf{F j}$ & -0.04 & +0.10 & & & -0.12 \\
\hline & Frh & & & & -0.27 & \\
\hline \multirow[t]{2}{*}{ A } & St & +0.26 & & & -0.32 & 0 \\
\hline & $\mathrm{Ga}$ & +0.22 & -0.13 & -0.04 & +0.16 & \\
\hline
\end{tabular}




\section{Appendix F \\ Palaeoenvironmental indication of kerogen categories}

In order to interpret the results of a palynofacies study of ancient, marine deposits, it is necessary to have detailed data from recent marine sediments for comparison.

The environmental indications of the different kerogen particle categories are discussed below. Most of the literature referred to here documents the distribution of organic sedimentary particles in recent, well studied, marine environments.

\section{Palynomorphs:}

This category comprises two main groups, the terrestrially derived palynomorphs (the spores and pollen), and the aquatic palynomorphs.

\section{Terrestrial palynomorphs}

The spores and pollen (sporomorphs) recorded from marine sediments originate from land plants. They are transported to the marine environment either by winds or streams. The relative importance of wind- and water transport varies, depending on the source vegetation (local or upland vegetation) (Traverse \& Ginsburg 1966, Chaloner 1968, Stanley 1969), and on the physical properties of the grains (size, weight and morphology) (Müller 1959, Koreneva 1964, Stanley 1965, 1969 , Traverse \& Ginsburg 1966, Mudie 1982). It appears, however, that fluvial transport is generally the most important for spores and pollen and for their distribution pattern in marine sediments (Müller 1959, Traverse \& Ginsburg 1966, Cross, Thompson \& Zaitzeff 1966, Groot 1966, Heusser 1978, 1983, 1988).

Once the sporomorphs are immersed in water, they behave like any other sedimentary particle, and are deposited according to their hydraulic properties. The size of most microspores and pollen grains is that of coarse- to medium silt but as they are hollow or only filled with protoplasm, they are hydraulically equivalent to smaller-sized mineral particles such as fine silt or clay, and are preferentially deposited with particles of this size (Müller 1959, Stanley 1965, Davey 1971, Reid 1972, Heusser 1988).

The compositions of sporomorph-assemblages in marine sediments partly reflect the nature of the parent vegetation, but as discussed above, they are strongly affected by hydrodynamic sorting processes which fractionate the original sporomorph content according to size, density and morphotype. In general, spores and pollen from the local flora are dominant in nearshore, fine grained sediments. Sporomorphs from upland regions become relatively more abundant farther offshore (Traverse \& Ginsburg 1966, Chaloner 1968, Davey 1971).

With the exception of the coarse-grained clastics of the "high energy" coastal environment, in which plant microfossils are very scarce or absent (Stanley 1965, Cross et al. 1966, Heusser 1988), the total spore-pollen content (grains per g. sediment) generally decreases offshore (Müller 1959, Traverse \& Ginsburg 1966, Cross et al. 1966, Stanley 1969, Davey 1971). Furthermore, the greatest diversity of plant microfossil taxa in the sediments has been reported near the coast with the variety of forms decreasing seaward (Stanley 1969).

Spores and pollen that are relatively heavy and/or lack airbladders (sacs), tend to decrease fairly rapidly in abundance offshore (Müller 1959, Mudie 1982), whereas the lighter and/or more buoyant types (e.g. bisaccate pollen) can be carried farther offshore, and thus increase in relative abundance seawards (Müller 1959, Koreneva 1964, Traverse \& Ginsburg 1966, Cross et al. 1966, Mudie 1982). For example, fern spores are primarily transported fluvially to the ocean, and are typically not transported substantial distances by ocean currents (Müller 1959, Cross et al. 1966, Heusser \& Balsam 1977, Mudie 1982). Bisaccate Pine pollen, on the other hand, are very buoyant, on account of their air bladders (sacs), and remain suspended for long periods (Traverse \& Ginsburg 1966, Brush \& Brush 1972, Heusser 1988). They are also known to be carried thousands of miles by air currents (e.g. Melia 1984). The relative percentage of Pine pollen therefore increases selectively seaward (Cross et al. 1966, Heusser \& Balsam 1977, Mudie 1982).

In Mesozoic sediments, bisaccate pollen generally seem to increase in relative abundance offshore and dominate the offshore assemblages (Hughes \& MoodyStuart 1967, Habib 1979, Tyson 1984).

According to Lund \& Pedersen (1985), trilete spores comprise relatively heavy, mainly water-borne palynomorphs. In their study of the Jurassic of Jameson Land, East Greenland, the frequency of trilete spores was believed to be inversely proportional to the distance from rivers and shorelines. A maximum of bisaccate 
pollen was interpreted as an indicator of maximum distance from land.

Dybkjær (1988) used a similar grouping of sporomorphs to indicate variations in the palaeoenvironment. Intervals with relatively high abundances of marine palynomorphs also show high abundances of bisaccate pollen, while trilete spores showed the reverse tendencies. These intervals were interpreted as phases of low freshwater influence within the depositional environment. They generally seem to correspond to "major pulses" of the Early Jurassic transgression (Hallam 1978, 1981).

\section{Aquatic palynomorphs}

The aquatic palynomorphs recorded from marine sediments consist partly of autochthonous elements (e.g. dinoflagellate cysts, acritarchs and foraminiferal testlinings) and partly of allochthonous elements, freshwater algae, transported into the marine environment by rivers and streams.

The presence of DINOFLAGELLATE CYSTS in fossil sediments is an almost certain indication of marine to brackish-marine conditions (Dale 1983). The ecological factors limiting the distribution of recent dinoflagellate cysts seem to be very complex, and are not well understood. According to Tyson $(1984,1987)$, dinoflagellate cysts are mainly produced in unstable, seasonally-mixed water masses, and are thus characteristically absent or rare in marine "black shales".

The sporomorph/dinoflagellate cyst ratio within sediments generally declines offshore (Stanley 1969, Davey 1971, Davey \& Rogers 1975, fig. 2).

The presence of ACRITARCHS generally indicates a marine environment. They are most numerous in the shallowest water assemblages, and also occur relatively abundantly in shallow bays and lagoons (Erkmen \& Sarjeant 1980). Furthermore they are sometimes introduced into freshwater environments (Hancock \& Fisher 1981).

In the acritarch group, cyst morphology seems to be associated with water depth and turbulence. Smallspined acanthomorph forms are characteristic of inshore environments (Wall 1965, Davey 1970, Fisher \& Hancock 1985). The longer-spined species are inferred to have been associated with less turbulent conditions, while the short-spined forms are concentrated in the high energy facies (Wall 1965). A more varied assemblage occurs in the more open marine sediments, including acanthomorph, polygonomorph (e.g. Veryhachium) and netromorph (e.g. Leiofusa) acritarchs (Wall 1965). These observations are compatible with those of Staplin (1961) in Devonian reef deposits of Alberta.
FORAMINIFERAL TEST-LININGS ("microforaminifera") are more abundant in open marine than in littoral and estuarine environments. Concentrations of foraminiferal test-linings have been recorded from areas of upwelling, and from shallow-water, saline environments (Cross et al. 1966).

THE PRASINOPHYCEAN ALGAE are pelagic organisms (Boalch \& Parke 1971). In Mesozoic black shales (the Early Toarcian Posidonia shale of Germany, the Volgian Kimmeridge Clay, and equivalents) the prasinophycean phycomata (Cymatiosphaera, Tasmanaceae, Pterospermales, and others) constitute an increased relative fraction of the plankton although they generally remain a small percentage of the total palynomorph population (Eisenack 1958, Wall 1965, Tyson 1984, Riegel et al. 1986).

Tasmanaceae have been recorded from shallow, brackish to marine environments, and modern forms range from open marine to inter-tidal mud-flat environments (Scull, Felix, McCaleb \& Shaw 1966, Fisher 1980). The ecology of modern Prasinophyceae is not known well enough to explain their apparent preference for bituminous muds since early Palaeozoic times. Perhaps this merely reflects the lack of competition from other planktonic algae more sensitive to $\mathrm{H}_{2} \mathrm{~S}$ contaminated water (Wille 1982).

FRESHWATER ALGAL remains can be transported to and deposited in marine environments, thus providing an indication of freshwater influence (Davey 1971).

The planktonic algae Botryococcus is normally considered to represent a freshwater algae, but is probably tolerant of slightly brackish water (Traverse \& Ginsburg 1966, Tappan 1980).

The algal genus Schizosporis is also indicative of freshwater influence (Balme \& Segroves 1966).

\section{Terrestrial plant debris (phytoclasts):}

BROWN WOOD (mainly tracheids) is almost entirely waterborne into the sea. These fragments are most abundant in regions where rivers debouch into the sea (Müller 1959, Cross et al. 1966). The larger fragments of tracheids are generally deposited nearest to the source, and the abundance and size of fragments decrease offshore (Müller 1959, Cross et al. 1966, Davey 1971, Davey \& Rogers 1975, fig. 2, Tyson 1989).

Woody debris is relatively resistant to physical and biological degradation and is capable of being recycled several times without significant deterioration (Fenchel \& Jørgensen 1977, Fisher 1980).

Davey (1971) divided tracheids into three sizegroups: 5-20 microns (small), 20-100 microns (medium), and $>100$ microns (coarse). He then made a 
visual assessment of the proportions in which these three categories occur. He defined eleven size groups based on various possible combinations of these categories (see Davey 1971, fig. 14), and presented a scheme on the basis of which it should be possible to interpret the energy of the depositional environment, and whether it is nearshore or offshore.

BLACK WOOD comprises carbonised woody material of two genetic types (Masran \& Pocock 1981, Pocock 1982):

1) Pyrofusinite (charcoal) formed by the incomplete combustion of wood or peat during natural fires.

2) Degradofusinite formed by subaerial, subaqueous, or groundwater oxidation of woody materials.

Once formed, it is extremely resistant to further oxidation and decay, and as a result is frequently all that remains following severe oxidation of an organic assemblage. Thus there is always a strong possibility that black wood may have been recycled several times (Cross et al. 1966, Schopf 1975). Such material is often the only type of kerogen recorded from coarse grained sediments, probably due to its resistance and its low buoyancy (Fisher 1980, text-fig. 1).

Due to secondary formation of black wood (by oxidation) the relative proportion of black wood in the phytoclast content is higher in more basinal sediments (Summerhayes 1987, Tyson 1989).

CUTICULAR MATTER behaves in a similar fashion to pollen and spores during transport and sedimentation in water (Cross et al. 1966). It is much less resistant to physical degradation than woody debris, and is thus rarely capable of surviving prolonged high energy transportation (Fisher 1980).

In the famous investigation of the Orinoco Delta by Müller (1959), cuticle fragments were found to be concentrated near the large delta estuaries. Both the abundance and the size decreased rapidly offshore.

RESIN has been found to be relatively abundant in highly oxidized (ancient) environments (Parry et al. 1981).

FUNGAL SPORES are probably liberated mainly from back swamp soils during heavy rainfall or by erosion of river banks. They can be transported over fairly large distances because of their generally small size (10-30 microns), but because of the lack of an initial period of wind transport, they have a more restricted distribution than tree-pollen of the same size (Müller 1959). Fungal spores and hyphae are especially numerous in deltaic deposits, and in regions where rivers debouch into the sea (Müller 1959, Cross et al. 1966, Scull et al. 1966)

\section{Amorphous organic matter (A.O.M.)}

A.O.M. is formed as the result of biodegradation of either marine or terrestrial source materials (Pocock 1982). It can originate from plant tissue, spores, pollen, phytoplankton and other algae, and thalloid algal matter (Venkatachala 1981b, Pocock 1982).

A.O.M. will form in any environment which is sufficiently moist and contains sufficient oxygen, or oxygencontaining compounds such as sulphates, to permit bacterial activity, but insufficient free oxygen to permit oxidation to proceed to completion (Pocock 1982).

The most important organisms responsible for the degradation process are bacteria (oxic and/or anoxic), fungi and aquatic invertebrates. Aquatic invertebrates play a major role in the degradation of organic material by reason of their burrowing activities. Bioturbation prolongs the residence time of organic matter at the sediment-water interface, the main site of degradation, and stimulates bacterial metabolism by maintaining a constant supply of organic substrates and oxidants (Yingst \& Rhoads 1980, Tyson 1987).

The occurrence of A.O.M. in quantity is indicative of preservation in oxygen-deficient conditions (Fisher 1980, Summerhayes 1981, Batten 1981, 1983), due to the limited duration of degradation by aerobic bacteria and the absence of a bottom fauna to bioturbate the sediment (Tyson 1987).

A.O.M. is normally scarce or absent in coast-near deposits, due to the effect of turbulence. Accumulation of A.O.M. need not, however, necessarily indicate deposition in relatively deep water; it is only necessary to be deep enough to form a stratified water column (Tyson 1987). It is frequently the dominant type of kerogen observed in organic-rich marine sediments, and tends to correlate with the T.O.C.-values (Fisher 1980, Summerhayes 1981, 1987, Summerhayes \& Masran 1983, Batten 1983, Tyson 1984, 1987, 1989). It has been suggested that rising sea-level can result in reducing bottom-conditions, thus increasing the likelyhood of preserving A.O.M. (Hallam \& Bradshaw 1979, Summerhayes \& Masran 1983). 


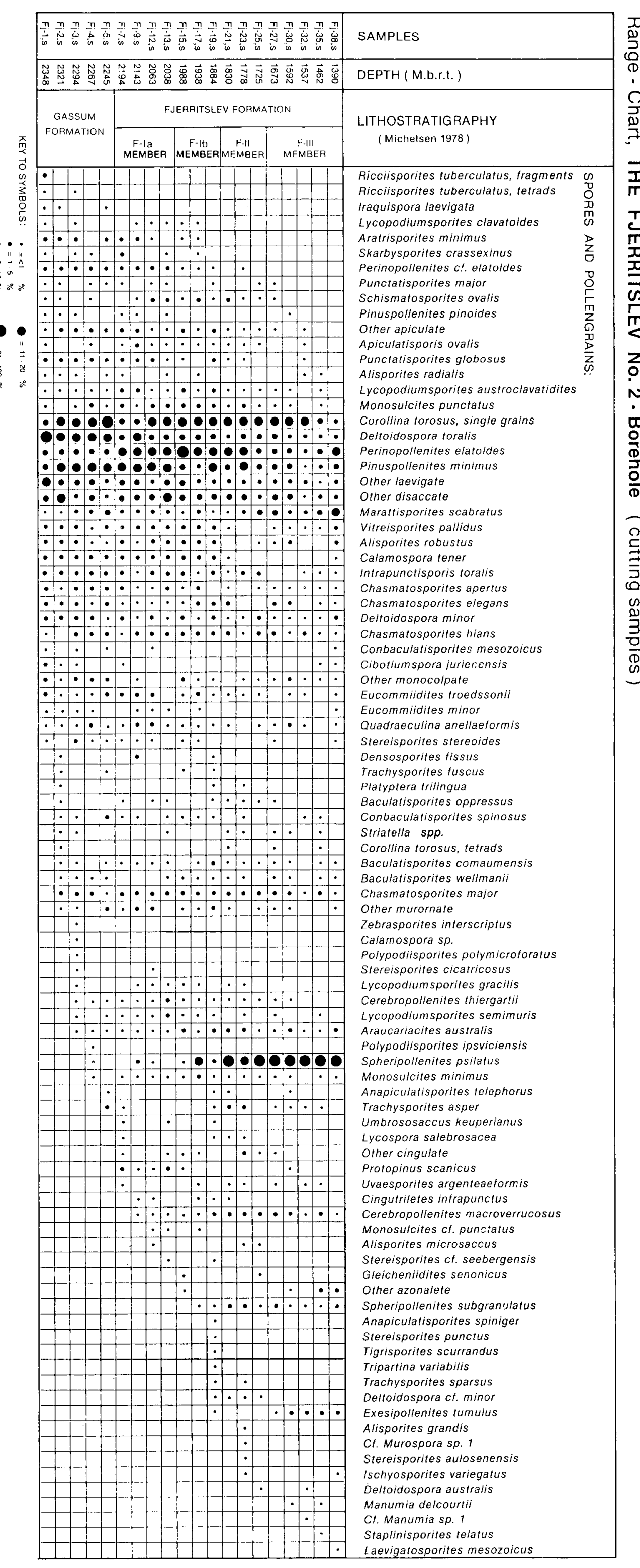

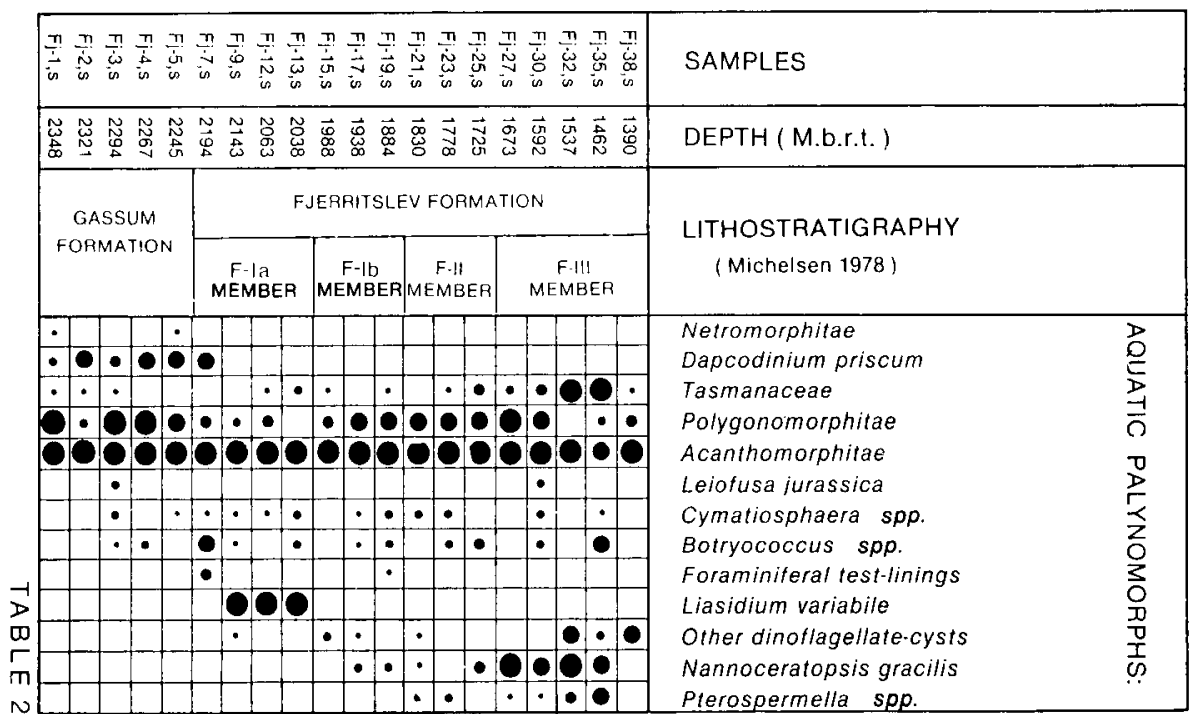

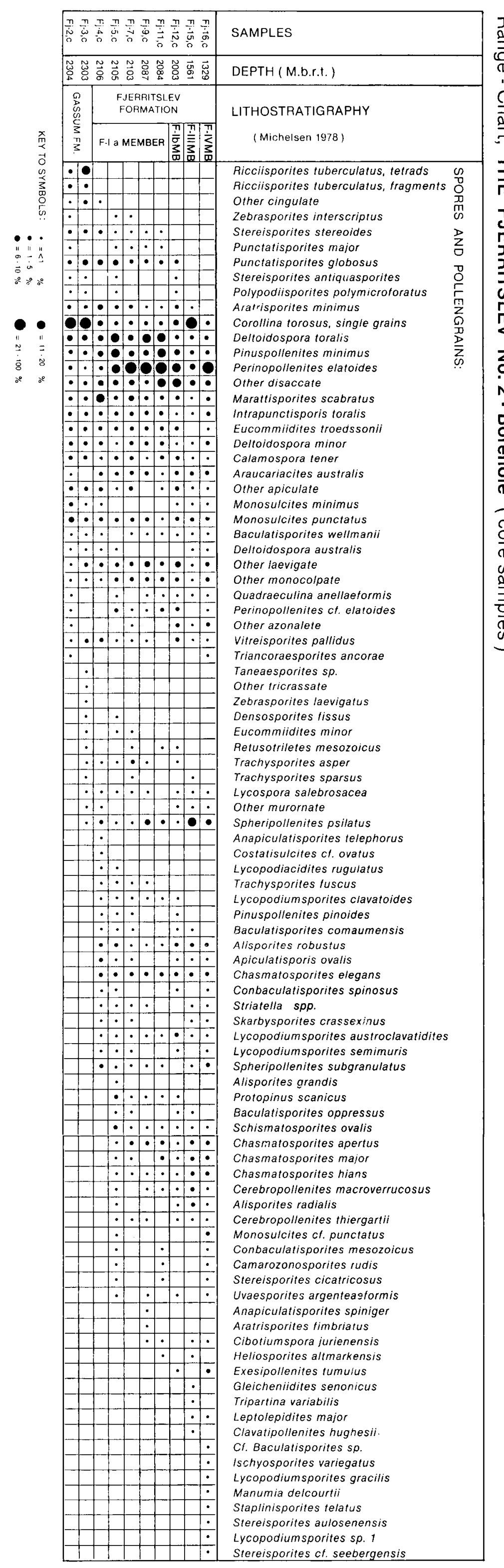

\begin{tabular}{|c|c|c|c|}
\hline 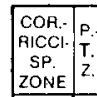 & $\begin{array}{l}\text { CEAEBRO- } \\
\text { POLLENIISES } \\
\text { MaCROVERR. } \\
\text { ZONE }\end{array}$ & 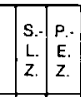 & SPORE / POLLEN ZONES \\
\hline \begin{tabular}{l|l} 
LATE \\
LAE \\
TAAN
\end{tabular} & 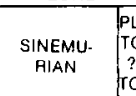 & 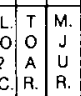 & AGE \\
\hline 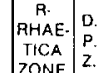 & 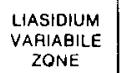 & $\begin{array}{l}\text { AAACI } \\
\text { GS } \\
\text { LOS }\end{array}$ & DINOFLAGELLATE CYST ZONES \\
\hline
\end{tabular}

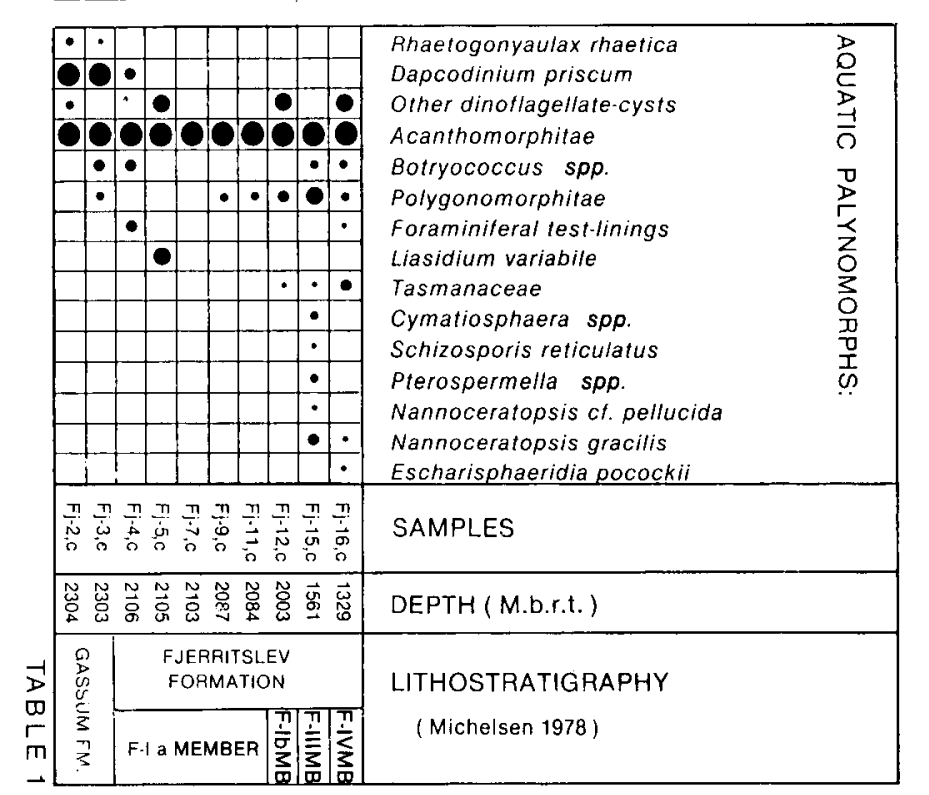




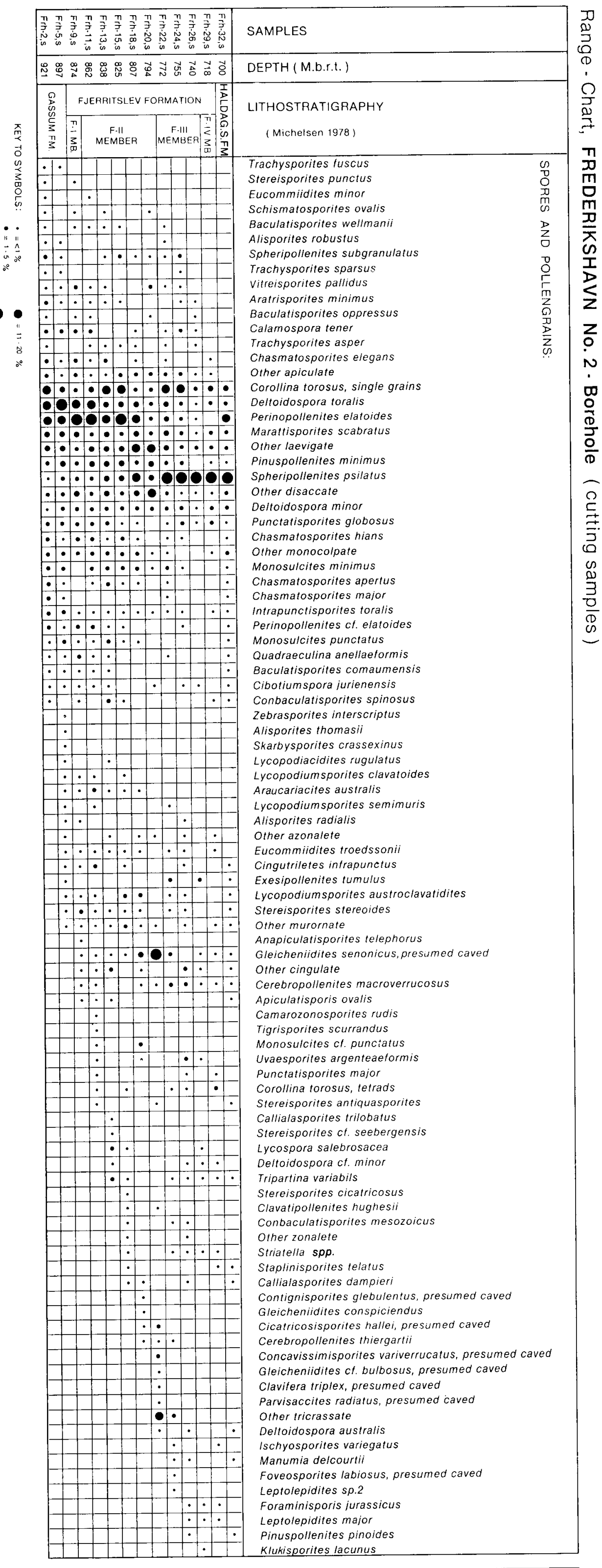

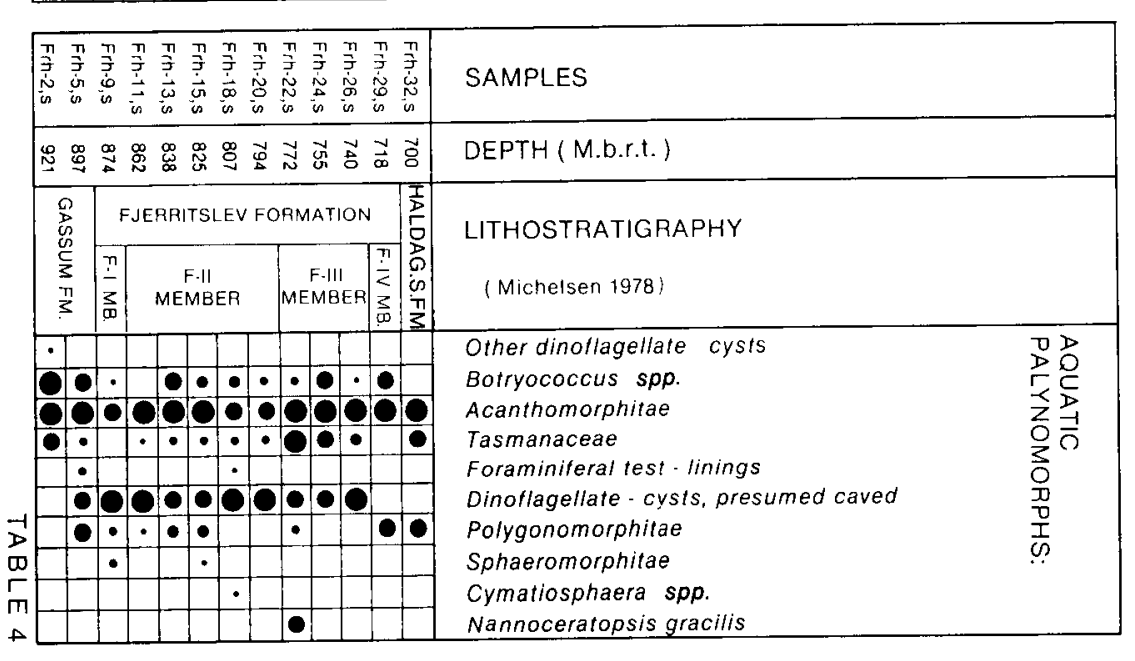

\begin{tabular}{|c|c|c|}
\hline 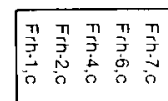 & 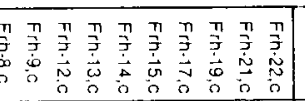 & SAMPLES \\
\hline 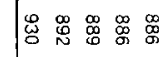 & 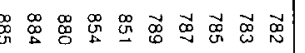 & DEPTH (M.b.r.t.) \\
\hline GASSIMM & FJERRITSLEV FORMATION & LITHOSTRAGRAPHY \\
\hline FORMATION & 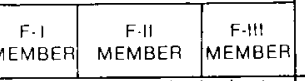 & (Michelsen 1978) \\
\hline
\end{tabular}
Uvaesporites argenteaetorm/s Zebrasporites interscriptus
Aratrisporites minimus

$\because \because \quad \quad \begin{aligned} & \text { trachysporites fuscus } \\ & \text { Clavatipollenites hughes }\end{aligned}$

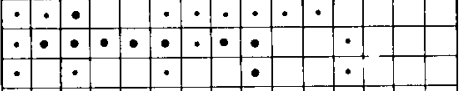

$\because \because \because \because \cdots$

$\because \therefore \therefore \therefore \because \because \because$

$\because \because \because \bullet \bullet \bullet \bullet \bullet \bullet \bullet \bullet$ (n) Protopinus scanilicus
Pinuspoltenites pinoides

Tachysporites asper

Striatella spp.

Punctatisporites glabosus

ses pallidus

$\because \because \cdots \cdots \bullet$ Delto idosporat toralis

$\because \because \because \because \because \because \because \because \bullet$ corollin torosusus, single grains

$\because \because \because \because \because \because \because$ Pinuspollenites minum

$\because \because \because \because \because \because \cdots$ Ohther dissaccate

$\because \because \because \because \because \because \because \because$ Maratisporties scabr

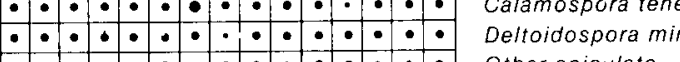

$\because \because \therefore \therefore \therefore \because \therefore \because$ Intrapunctisporis toralis

$\because \because \because \therefore \because \therefore$ Monosulcites minim

$\therefore \quad \therefore \quad \therefore \quad \begin{gathered}\text { Alisporites radiatis } \\ \text { Baculatissorites comaumensis }\end{gathered}$

$\therefore$. Bacutatsporities wellmani

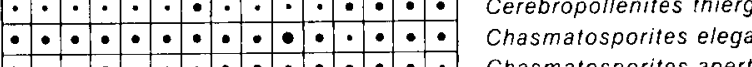

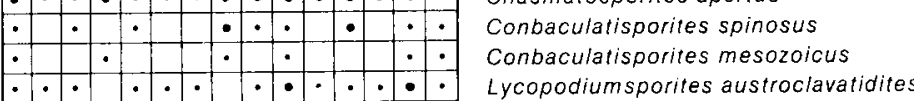

$\therefore \therefore \quad \therefore \quad$ Lycossora salebrosesceas

$\because \ldots \ldots \ldots$ ouadraeculina aneltaetormis

$\because \therefore \ldots$ spheripolientres psiliatus

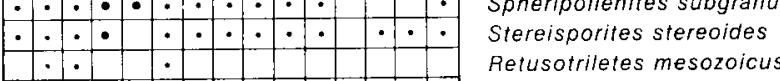

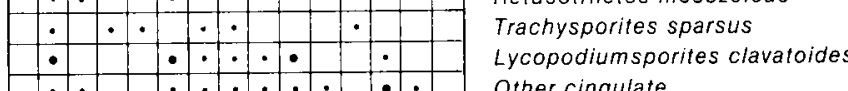

$\because \because \because \because \because \quad \begin{aligned} & \text { Other cingulate } \\ & \text { Baculatisporites oppressus } \\ & \text { searbosposites }\end{aligned}$

$\therefore \quad \cdots \cdots \cdots$ Lycopodium sporites semimurts

$\therefore \ldots \therefore \quad \therefore$ Araucariacites australlis

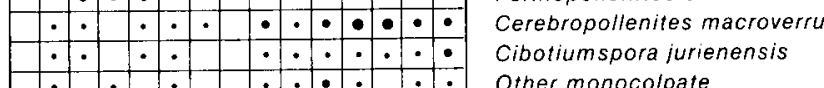

$\because \quad \cdots \quad 0 \quad$ Other monocolpate

$\because \cdot \because \cdot \div \quad: \quad \begin{aligned} & \text { Monosuldites ct. punctatus } \\ & \text { stereisporites cicatricosus }\end{aligned}$

$\because \quad \cdot \quad \cdot \quad \cdot \quad \begin{aligned} & \text { Umbrososaccus keuperian } \\ & \text { Deltoidospora australis }\end{aligned}$

$\because \cdots \quad \cdots \quad \cdots \quad \begin{aligned} & \text { Eucommititites minor } \\ & \text { Lycopodiacidites ugulatu }\end{aligned}$

$\therefore \because \cdots \quad$ Apiculatisporis ovalis

$\because \because \cdots \cdots \cdot \begin{aligned} & \text { Other azonalete } \\ & \text { chasmatesporites major } \\ & \text { Tigrisporites scurrandus }\end{aligned}$

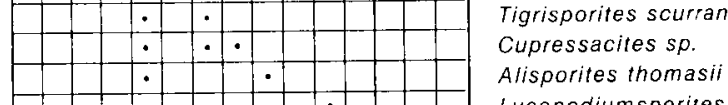

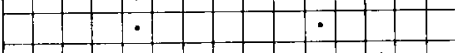

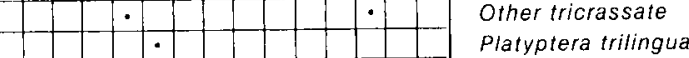

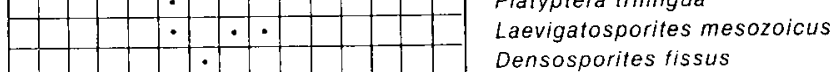

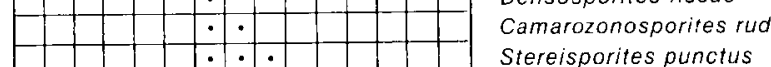

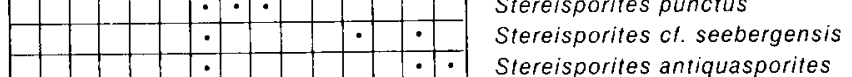

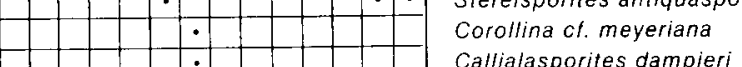

Caltilalasporites dampilin
Tripartina variabilis

Tripartina variabilis
Gleicheniidites senonicus

Exechipantertites senonicus
Exespollenties tumulus

Stereisporites aulosenensis

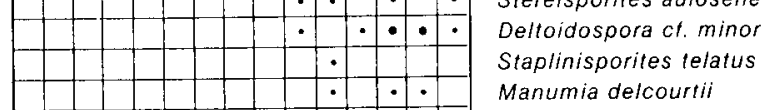

$-1 \quad: \because \because-\begin{aligned} & \text { Manumla delcourtim } \\ & \text { Alisporites grandis }\end{aligned}$

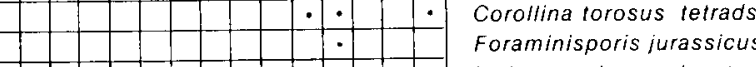

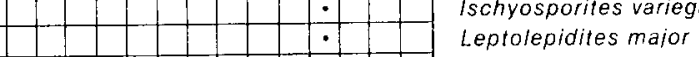

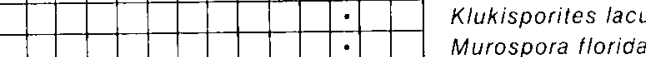

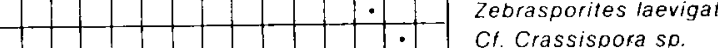

\begin{tabular}{|c|c|c|c|}
\hline $\begin{array}{l}C \\
C \\
R \\
\end{array}$ & $\begin{array}{l}\text { CEREBROPOLLENITES } \\
\text { MACROVERRUCOSUS } \\
\text { ZONE }\end{array}$ & \begin{tabular}{|c|} 
SPHERR: \\
POLLENIT. \\
LEPTOLEFP. \\
ZONEE \\
\end{tabular} & SPORE / POLLEN ZONES \\
\hline 尊 & $\begin{array}{l}\text { EAALLEST } \\
\text { SINEMUAIAN }\end{array}$ & TOARCIAN & AGE \\
\hline & $\begin{array}{l}\text { DAPCODINIUM } \\
\text { PRISCUM ZONE }\end{array}$ & $\begin{array}{l}\text { NANNOCERA } \\
\text { TOPSIIS GAAA } \\
\text { CILIS ZONE }\end{array}$ & DINOFLAGELLATE CYST ZONE \\
\hline
\end{tabular}

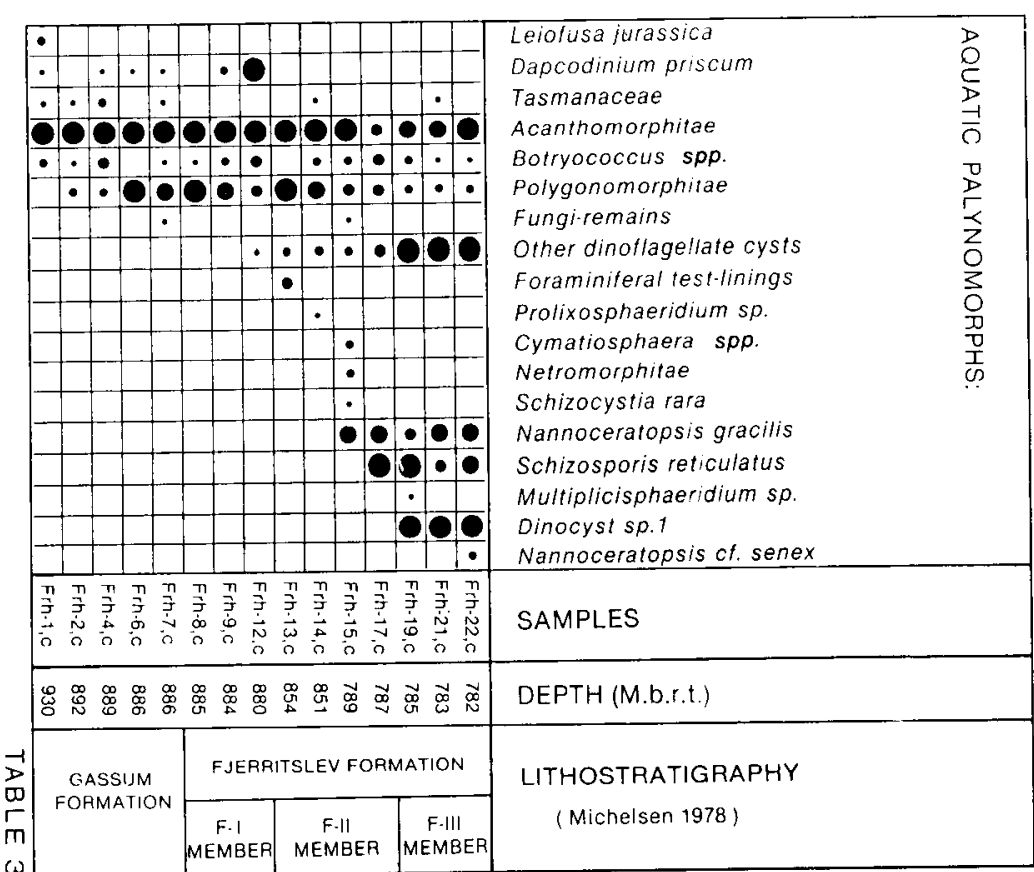




\begin{tabular}{|c|c|c|}
\hline 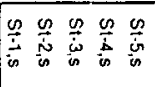 & SAMPLES & \\
\hline 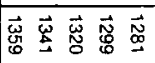 & DEPTH (M.b.r.t.) & \\
\hline & \multirow{2}{*}{\multicolumn{2}{|c|}{ 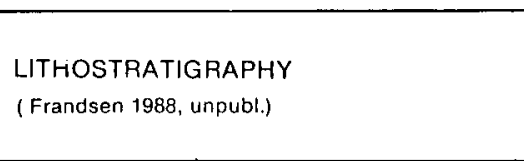 }} \\
\hline Fefbo & & \\
\hline & \multirow{25}{*}{\multicolumn{2}{|c|}{ 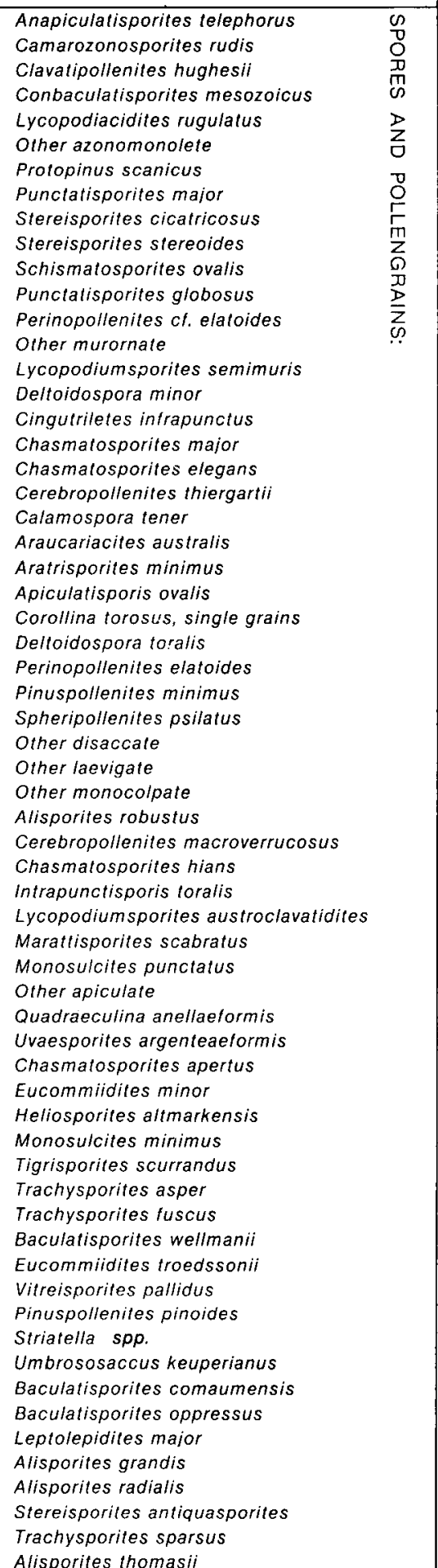 }} \\
\hline & & \\
\hline & & \\
\hline & & \\
\hline & & \\
\hline & & \\
\hline & & \\
\hline$\because$ & & \\
\hline & & \\
\hline & & \\
\hline & & \\
\hline & & \\
\hline & & \\
\hline & & \\
\hline & & \\
\hline & & \\
\hline$\because \because$ & & \\
\hline & & \\
\hline & & \\
\hline & & \\
\hline$\because \because$ & & \\
\hline & & \\
\hline & & \\
\hline & & \\
\hline $11 \%$ & & \\
\hline 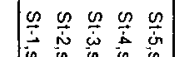 & \multicolumn{2}{|l|}{ SAMPLES } \\
\hline 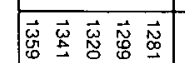 & \multicolumn{2}{|l|}{ DEPTH (M.b.r.t.) } \\
\hline & \multirow{2}{*}{\multicolumn{2}{|c|}{$\begin{array}{l}\text { LITHOSTRATIGRAPHY } \\
\text { (Frandsen 1988, unpubb!) }\end{array}$}} \\
\hline $\begin{array}{l}\text { Exild } \\
\text { meneref }\end{array}$ & & \\
\hline$\because \because 9 \bullet$ & 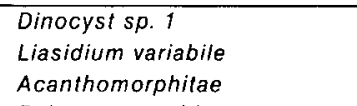 & 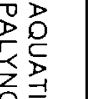 \\
\hline$\because \because$ & 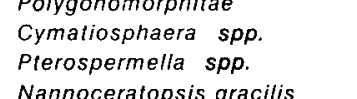 & 尊 \\
\hline$:$ & 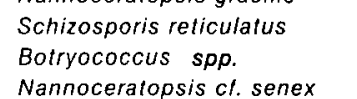 & \\
\hline
\end{tabular}
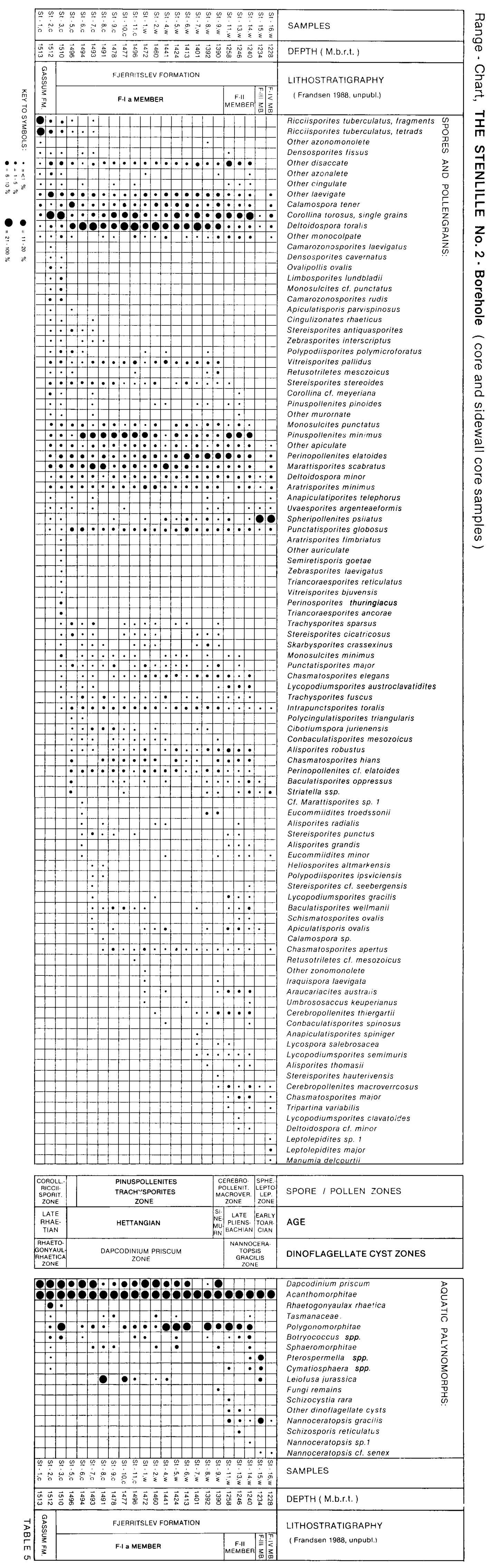
This paper presents a combined spore/pollen- and dinoflagellate cyst zonation and dating of the Lower to lowermost Middle Jurassic Fjerritslev Formation in the Danish Subbasin.

The results of a detailed palynofacies-investigation generally support the previous interpretations of the depositional environment, and contribute new information. In addition, the hydrocarbon potential of the succession is assessed. 